\title{
Market competition and efficient cooperation
}

Citation for published version (APA):

Brandts, J., \& Riedl, A. M. (2016). Market competition and efficient cooperation. Maastricht University, Graduate School of Business and Economics. GSBE Research Memoranda No. 006 https://doi.org/10.26481/umagsb.2016006

Document status and date:

Published: 01/01/2016

DOI:

10.26481/umagsb.2016006

Document Version:

Publisher's PDF, also known as Version of record

\section{Please check the document version of this publication:}

- A submitted manuscript is the version of the article upon submission and before peer-review. There can be important differences between the submitted version and the official published version of record.

People interested in the research are advised to contact the author for the final version of the publication, or visit the DOI to the publisher's website.

- The final author version and the galley proof are versions of the publication after peer review.

- The final published version features the final layout of the paper including the volume, issue and page numbers.

Link to publication

\footnotetext{
General rights rights.

- You may freely distribute the URL identifying the publication in the public portal. please follow below link for the End User Agreement:

www.umlib.nl/taverne-license

Take down policy

If you believe that this document breaches copyright please contact us at:

repository@maastrichtuniversity.nl

providing details and we will investigate your claim.
}

Copyright and moral rights for the publications made accessible in the public portal are retained by the authors and/or other copyright owners and it is a condition of accessing publications that users recognise and abide by the legal requirements associated with these

- Users may download and print one copy of any publication from the public portal for the purpose of private study or research.

- You may not further distribute the material or use it for any profit-making activity or commercial gain

If the publication is distributed under the terms of Article $25 \mathrm{fa}$ of the Dutch Copyright Act, indicated by the "Taverne" license above, 


\section{Maastricht University}

Jordi Brandts, Arno Riedl

Market Competition and Efficient Cooperation

RM/16/006

\section{GSBE}

Maastricht University School of Business and Economics

Graduate School of Business and Economics

P.O Box 616

NL-6200 MD Maastricht

The Netherlands 


\title{
Market Competition and Efficient Cooperation
}

\author{
Jordi Brandts Arno Riedl*
}

December 23, 2015

\begin{abstract}
We use laboratory experiments to study the causal effects of favorable and unfavorable competitive market experience on cooperation in a subsequent social dilemma game. The issues we study are part of the broader topic of whether there are behavioral spillovers between different spheres of social interactions. Market interaction takes place in a continuous double auction market in which one side of the market obtains the larger part of the surplus. We examine the efficiency of subsequent cooperation for pairs of market-winners, market-losers and mixed pairs and study both the cases where interaction in the social dilemma is with others from the same market, 'market-partners', and where it is with others from another market, 'market-strangers', and compare it with benchmark behavior in a stand-alone social dilemma game. We find that in market-partners, market experience has adverse effects on the efficiency of cooperation on both market-winner and market-loser pairs. In market-strangers, pairs of market-winners manage to cooperate more efficiently. These results indicate that it is not market experience per se that lowers the ability to cooperate. Rather, having competed for scarce resources on the same side of the market makes it difficult to overcome the social dilemma and positive market experience fosters cooperation only for those who did not have to compete with each other. We also show that differences in cooperation cannot be explained by ex-ante income differences and find that market experience also affects subjective well-being and social value orientation.
\end{abstract}

Keywords: Competition, Cooperation, Experiments

JEL: A13, C92, D30, J50, M50

\footnotetext{
*Jordi Brandts: Instituto deAnalisis Economico (CSIC) and Barcelona GSE; jordi.brandts@iae.csic.es; Arno Riedl: CESifo, IZA, Netspar, and Maastricht University, Department of Economics (AE1), P.O. Box 616, 6200 MD Maastricht, the Netherlands, a.riedl@maastrichtuniversity.nl. The authors thank the Spanish Ministerio de Economa y Competitividad (Grant: ECO2011-29847-C02-01), the Generalitat de Catalunya (Grant: 2009 SGR 820), the Antoni Serra Ramoneda Research Chair (UAB-Catalunya Caixa) for financial support.
} 


\section{Introduction}

In economics markets are traditionally studied separately from other spheres of social interaction, with the focus of analysis typically being on the allocation of resources in the markets in question. This way of proceeding is certainly meaningful when the focus is solely on the efficient allocation of scarce resources. However, studying markets in isolation can lead to important omissions in our understanding of their overall welfare effects, by disregarding possible spillovers of market activity onto interaction in other spheres of social and economic life.

Market competition is commonly considered to be a beneficial force and there is no doubt that competitive markets can lead to efficient allocations of resources, as suggested by many field observations and demonstrated theoretically in the First and Second Welfare Theorems (see, e.g., Mas-Colell et al., 1995) and empirically in experiments with double auctions and other competitive market institutions (see Smith, 1962, for the seminal paper and Davis and Holt, 1993, for a survey). However, an important question is whether the efficiency effect of markets is not be circumscribed to the market environment itself but extends beyond it, thereby affecting efficiency in other spheres. This seems especially relevant in relation to interactions through personal exchange where cooperation can not be completely regulated through formal contracts. In this paper we study this, by exploring whether, and if so how, market experience affects the efficiency of cooperation in a social dilemma situation.

Spillover effects may also interact with the fact that market participation can take place under different conditions. A salient feature of modern market societies is that the productive assets - including human capital - that allow people to generate wealth and income are distributed rather unequally (see, e.g., Cowell and Van Kerm, 2015). As a consequence, some people's skills or assets are in high demand in the market, with many others trying to transact with them, while those of others are in much lower demand. Some people may even have difficulties to trade at all. Moreover, for many individuals being in a favorable or unfavorable market situation will be constant over their life-time; often it even carries over between generations (Restuccia and Urrutia, 2004; Black et al., 2005). The most prominent case of such situations are labor markets where a large number of low-skilled workers compete for a limited number of jobs, implying wage inequalities and involuntary unemployment (e.g., Marquis et al., 2014)

Another important circumstance that may matter for the efficiency of cooperation is whether one is immersed into a social dilemma situation with somebody, one also has to compete with in the same market or not. The question arises whether different market experiences will affect 
the efficiency of interaction in spheres where cooperative behavior outside a market setting is necessary to achieve efficient outcomes. An example at hand, is voluntary contributions to local public goods in low income neighborhoods where neighbors may compete fiercely for jobs on the same labor market versus high income neighborhoods where neighbors are unlikely to be direct competitors on the labor market. More generally, different market positions may affect the social capital of people and thereby undermine the ability to cooperate efficiently. For instance, Lelkes (2010) documents that poor people are more likely to be isolated than non-poor.

We use laboratory experiments to address these questions because these allow us to study the effect of participating in a market under different conditions on the efficiency of voluntary cooperation in a causal way and under highly controlled conditions. Specifically, we compare behavior in a social dilemma game that is preceded by market interaction with behavior in the absence of market interaction. In our study, market interaction takes place in a highly competitive continuous double auction (see Smith, 1962). In experiments, the double auction has been shown to be the institution that best embodies the characteristics of efficient markets where prices and transactions come about through a decentralized equilibrating process, that converges to the Walrasian outcome (see, e.g., Davis and Holt, 1993). It is the effect on cooperation of having experienced such highly competitive and efficient markets we are interested in.

Next to a general effect of competitive market experience, our experimental set-up also allows us to explore two specific dimensions of how market participation may spill over to non-market social dilemma environments. First, we can investigate if and how effects differ depending on whether people are on the favorable or unfavorable side of the market. We achieve this by using a so-called box-design of competitive markets that involve a long and a short side of the market (Holt et al., 1986). This asymmetry corresponds to market conditions in which individuals on one side of the market will easily make transactions at favorable prices, whereas individuals on the other side of the market will have difficulties to make transactions and will do so at unfavorable prices, if they transact at all. This feature represents in a stark way the very unequal opportunities that exist in some market economies or market segments (e.g., labor markets for high and low skilled workers). In our context, earnings differentials will arise endogenously from market interaction as a consequence of these different opportunities. That is, so-called marketwinners will have high earnings, whereas so-called market-losers will have much lower earnings. We will control for the effect of these earnings differences on behavior in the social dilemma situation. Our focus, however, will be on the implications of the different market experiences distinct market participants will have. 
The second dimension of market experience relates to whether people have to overcome the social dilemma problem together with people with whom they have or have not had a joint market experience. It may make a difference whether someone has to supply a public good jointly with a neighbor who is competing for the same job or with somebody who is not seen as a competitor on the labor market. Similarly, in a social dilemma situation, people may behave differently towards a potential employer or employee than to somebody with whom one has not traded with (and will not trade with in the future).

The social dilemma game we use is a repeated two-person public goods game in which pairs are fixed throughout all rounds. Public goods games are a standard tool for studying cooperation (Chaudhuri, 2011; Kagel and Roth, 2012). To study the first dimension of differences in market experience, we implement in the social dilemma game different pairings of participants from the same and opposite market sides. This allows us to explore the impact of being respectively market-winner and market-loser on the efficiency of cooperation. To study the second dimension, we also vary whether pairings in the social dilemma game come from the same market, marketpartners, or from different markets, market-strangers. Finally, our set-up also allows us to explore interaction effects between the two discussed dimensions of market experience.

Our study of possible spillovers of market competition relates to the broader issue of the influence of institutions on preferences, which is an under-explored topic in economics. Fehr and Hoff (2011) argue that economists' traditional reluctance to explain changes in behavior in terms of changes in preferences was partially motivated by the difficulty of producing conclusive scientific evidence in favor of the preferences hypothesis with natural data. Given this difficulty they suggest that the use of experimental data (field, natural and quasi-experimental) may be a promising strategy for learning more about this issue. Relatedly, van Winden (2012) argues that to understand relationships between people one needs to take into account the existence of social ties and how they are affected by the context in which social interactions take place. Bowles and Polania-Reyes (2012) present an extensive survey of the evidence documenting that social motivations are not necessarily separable from the environment and experiences related to the environment.

In the economics literature, two contrasting views are identifiable in relation to potential spillover effects of markets on cooperative non-market environments. Vernon Smith (1998) builds on Adam Smith to postulate that people intuitively know how to behave both in a cooperative and in a competitive way depending on the context. According to this view, both behaviors grow out of a universal propensity for social exchange which "finds expression in both personal exchange in 
small-group social transactions and in impersonal trade through large-group markets." (Smith, 1998, p.3) Smith sees cooperative and non-cooperative behavior as peacefully coexisting, with efficiency in impersonal markets being based on competitive behavior, while efficiency in personal social and economic exchange requires reciprocity.

Henrich et al. (2001) extend this argument and suggest that market interaction can have positive effects on cooperation. They study behavior in ultimatum games, public good games and dictator games in 15 small-scale societies with a variety of economic and cultural conditions and relate the results to a non-experimental measure of market integration. They find that "the higher the degree of market integration (...) the greater the level of cooperation in experimental games." (Henrich et al., 2001, p.74) The rationale for this relation proposed by these authors is that "the more frequently people experience market transactions, the more they will also experience abstract sharing principles concerning behaviors towards strangers (...)." (Henrich et al., 2001, p.76) This is consistent with the notion of doux commerce as put forward among others by Montesquieu (1748) already in the eighteenth century.

In contrast, Bowles (1998) suggests that market participation can adversely effects people's personality. Specifically, he argues that “(...) there are significant differences in the personality effects on participants in markets (...) for people on the short side (...) and those on the long side of the market, some of which are simply excluded from the exchange process, while others fear losing the transactions they have secured." (Bowles, 1998, p.78) Bowles' concerns can be seen as part of the broader question asking whether market exchange erodes moral and civic goods worth preserving. Sandel $(2012,2013)$, for instance, argues that certain market exchanges are objectionable on moral grounds and may also crowd out non-market norms 1

The diverging views on the potential spillover effects of market participation call for empirical work that can provide insights into their relative merits. If the negative spillover effects of market participation discussed by Bowles indeed affected the efficiency of voluntary cooperation this would be a major challenge for societies in which markets play a central role 2 However, as mentioned above, there are also reasons to believe that market participation is innocuous or has even beneficial effects on the efficiency of non-market interactions. With our study we want to contribute on shedding light on this important issue.

\footnotetext{
${ }^{1}$ For a survey of different views of market society, see Fourcade and Healy (2007).

${ }^{2}$ Our focus is on spillover effects on efficiency, because they are more directly economically relevant. However, spillover effects could also be on psychological dimensions like efficacy as captured in the Rotter score (see Rotter, 1966) or social dominance orientation (see Sidanius and Pratto, 2004).
} 
In the field non-market interactions are affected by a multitude of factors which makes it difficult to tease out the effect of market experience on the basis of field data. The use of laboratory experiments makes it possible to study spillover effects of market participation with a high degree of control under ceteris paribus conditions. Specifically, we are able to exogenously assign participants to the two sides of the market. Without laboratory control naturally more cooperative people might be over-represented on one or the other side. Similarly, we are able to control the composition of the groups in the subsequent social dilemma and, hence, study behavior for all possible matchings between participants with different market experiences 3

The comparisons between the distinct matchings in the social dilemma we focus on are inspired by the work of Henrich et al. (2001) and by the remarks of Bowles (1998). First, the findings of Henrich et al. (2001) suggest that pro-social behavior is enhanced by market integration with strangers. We explore whether the efficiency of cooperation indeed depends on whether it takes place between people who compete in the same market (market-partners) or on different markets (market-strangers). This distinction is meant to capture the distinction between more local markets, where the same people compete for scarce resources and have to cooperatively provide a public good, and more anonymous interactions, where the sets of people one is, respectively, competing and cooperating with are distinct.

Second, our comparison of behavior in the social dilemma for matchings of people that have been on the long side or on the short side of the market corresponds quite directly to the one proposed by Bowles. It will allow us to explore whether matchings of lucky market-winners behave differently from matchings of unlucky market-losers. Importantly, our experimental setup includes a treatment which allows us to separate the effects of being on the short or long side of the market, from that of obtaining higher or lower earnings. This is crucial, because we are interested in the consequences of different market experiences and not in those of income differences generated by different market experiences. As different market positions inevitably are associated with different earnings potentials, this separation would be virtually impossible with field data.

In brief our main results are as follows. For market-partners competitive market experience has adverse effects on efficient cooperation in both market-winner and market-loser matchings. In market-strangers, matchings of market-winners manage to cooperate more efficiently. These results indicate that it is not market experience per se that lowers the ability to cooperate.

\footnotetext{
${ }^{3}$ Another advantage of lab experiments is that the possibility of replication allows for a systematic study of the relevant issues. See Falk and Heckman (2009) for a recent methodological discussion of laboratory experiments.
} 
Rather, having competed for scarce resources on the same market makes it difficult to overcome the social dilemma, virtually irrespective of having been a market-loser or market-winner. Moreover, positive market experience can foster cooperation, but only for those who did not have to compete with each other before. These differences in cooperation cannot be explained by differences in earnings. In addition, we also take self-assessed measures of experienced well-being and incentivized measures of social value orientation. Our results suggest that market experience affects both subjective well-being and social value orientation.

\section{Related Experimental Literature}

There are a number of related experimental papers studying the effect of competition on behavior, but none of them deals with how interaction in competitive markets affects subsequent efficiency in cooperation. Brandts et al. (2009) study the effects of competitive rivalry on the disposition towards others and on subjective well-being. They focus on pure rivalry and chose a design of a finitely repeated interaction between fixed triads of players, where one of the three players can in each round choose with whom of the other two players to play a prisoner's dilemma game, leaving the third player without interaction. After the interaction rounds, measures of subjects' disposition towards others and experienced well-being were taken. The authors find that rivalry has indeed a differential impact on individuals depending on which side of the rivalry they were on. It negatively affects experienced well-being of those on the powerless side of the interaction and has a positive effect for the powerful player leading to a larger inequality in experienced well-being. Interacting under rivalry also affects negatively the disposition towards others.

Bauernschuster et al. (2013) study how competition between two investors interacts with trust and trustworthiness in simple one-shot trust games. They find that competition among trustors does not significantly increase sent amounts. However, trustees react to competition between trustors by lowering return ratios. Similarly, Huck et al. (2012) study a repeated binary trust game that resembles a market for an experience good with a fixed price where the buyer can choose whether to trust or not and the seller can only choose quality. Without competition, buyers are in each period randomly assigned to sellers. With competition, buyers choose in each period the seller from whom they want to buy. The authors report that the introduction of competition is highly effective, with market efficiency rising from 30 to over 80 percent.

Herz and Taubinsky (2013) study how experience with competition shapes fairness standards. In their experiment participants first take part in ultimatum games with either proposer 
or responder competition and then play the standard ultimatum game. They find that responders' acceptance thresholds are higher for responders that started in the game with proposer competition than for those who started in the game with responder competition.

Carpenter and Seki (2006) report on a field experiment conducted with three groups of workers from a fishing community in Japan, where the different groups were exposed to different amounts of competition on-the-job. The results show that these differences explain differences in cooperation in an experimental setting. Specifically, fishermen and traders, who interact in more competitive environments are significantly less cooperative than staff who faces little competition on the job.

Falk and Szech (2013) study behavior in a context in which market exchange can produce a negative externality - in their case the death of mice. They find that repeated market interaction typically yields less socially responsible behavior than one-shot non-market behavior. Bartling et al. (2015) present a comparison of social concern between Switzerland and China. They study behavior in both a non-market and a market context. They find that in both countries subjects exhibit less social concern in a market than in a non-market environment. In addition, they find that while there is no cross-country difference in behavior in a non-market context, in a market context social concern is lower in China than in Switzerland.

Two studies compare the effects of interacting under tournament and under piece-rate incentives of subjects on Amazon Mechanical Turk on subsequent behavior. Buser and Dreber (2013) find that individuals are significantly less cooperative in a public goods game after having interacted under tournament incentives than under piece-rate. In contrast, Chen (2011) finds that “...the moral influences of competition are ameliorative in ways that philosophers and economists have traditionally considered ameliorative" (p. 27).

Our focus and set-up is different from these previous studies. We are interested in exploring the efficiency effects of the societal experience of market competition in a situation where virtually all market power is on one side of the market, whereas the other side has to scramble to obtain the crumbs of the exchange surplus, as captured in the notion of the reserve army of labor introduced by Engels (1845) 4 In addition, we explore if and how these different market power experiences interact with whether or not one has to solve the social dilemma with those one also had to compete with on the market. We believe that the effects of such situations are of socio-economic

\footnotetext{
${ }^{4}$ Some observers, see e.g. Standing (2011), consider that in modern globalized economies there now exists a new reserve army of labor, comprised of temporary and part-time workers, who lack any type of job security.
} 
importance and need to be studied in depth. We are not aware of any other experimental work on the matter. In Section 5 we develop specific hypotheses regarding these effects.

\section{Experiment Design}

Our design has three main building blocks: (1) measurements of subjective well-being and social value orientation, (2) a highly competitive continuous double auction market (hereafter, DAM) and (3) a social dilemma game (hereafter, SDG). Our design consists of four treatments, two market treatments in which the DAM is played before the SDG, and two control treatments in which the SDG is played in isolation. The two market treatments differ in the matching of players in the subsequent SDG and the two control treatments differ in the income subjects receive before playing the SDG. All treatments also involve two measurements of subjective well-being and of social value orientation. We first describe in detail the two market treatments followed by a description of the control treatments 5

\subsection{The Two Market Treatments}

Both market treatments consisted of eight parts. Table 1 shows the sequence of events. At the very beginning, participants were informed that the experiment would have several parts. Instructions for the various parts were given separately for each part, except those for parts 3 and 4 which were presented together.

Table 1. Sequence of events in market treatments

\begin{tabular}{llc}
\hline \hline 1. & Self-assessment of subjective well-being & (SWB 1) \\
2. & Measurement of social value orientation & (SVO 1) \\
3. & Double auction market (18 rounds) & (DAM) \\
4. & Social dilemma game (6 rounds) & (SDG) \\
5. & Self-assessment of subjective well-being & (SWB 2) \\
6. & Measurement of social value orientation & (SVO 2) \\
7. & Surprise restart social dilemma game (12 rounds) & (sSDG) \\
8. & Post-experiment questionnaire & \\
\hline
\end{tabular}

In part 1 (SWB 1) all participants had to answer a self-assessment question to measure their initial subjective well-being and in part 2 (SVO 1) they had to make money allocation decisions to measure their social value orientation. In part 3 (DAM) they interacted in 18 rounds of the DAM and in part 4 (SDG) in six rounds of the SDG. In parts 5 and 6 (SWB 2 and SVO 2,

\footnotetext{
${ }^{5}$ The experiment instructions can be found in Appendix B
} 
respectively) participants had again to self-assess their subjective well-being and make money allocation decisions to measure post interaction social value orientation. Part 7 (sSDG) consisted of a 'surprise' restart of the SDG, lasting for 12 rounds. In part 8, participants answered questions about their individual characteristics.

Parts 1 and 2: SWB 1 and SVO 1. In SWB 1 we recorded participants' response to the subjective well-being question shown in Figure 1. These initial measurement provides the baseline to which the second measurement will be compared. Subjects were asked to mark the number related to the expression of the manikin that best corresponded to how they felt at that moment 6 In the figure, "1" corresponds to the highest level and " 9 " to the lowest level of subjective well-being.

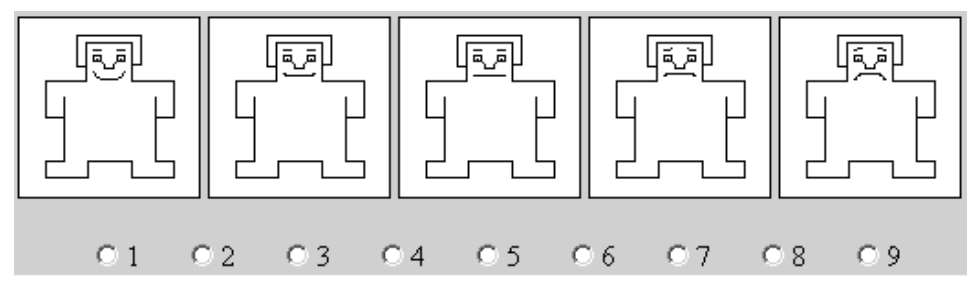

Note: "1" indicates highest level, ..., "9" indicates lowest level of subjective well-being

Figure 1. Subjective well-being self-assessment

In SVO 1 we recorded participants' social value orientation using the so-called circle-test. The circle-test is a modified and incentivized version of the ring-test (Liebrand, 1984) and was successfully applied by, among others, Sonnemans et al. (2006) and Brandts et al. (2009). It is a simple task which allows for a quantification of individuals' social value orientation by determining the readiness of individuals to help or hurt others at some cost to themselves. Figure 2 shows an example of a circle-test as used in the experiment.

In the circle-test a person's social value orientation is measured by a single decision which consists of the selection of a point on a circle. Each point on the circle represents an allocation $S$ of Experimental Currency Units (ECU) to the person who makes the choice (Self) and an allocation $O$ of ECU to another person (Other). The amounts allocated can be positive or negative, with $S^{2}+O^{2}=200^{2}$. Note, that each point on the circle corresponds to a certain angle of the line connecting that point with the origin, which we will use as the measure of social value orientation. For instance, an angle of 0 degrees corresponds to selfishness as it allocates

\footnotetext{
${ }^{6}$ These figures, developed by Lang (1980), are based on Sonnemans (1991).
} 


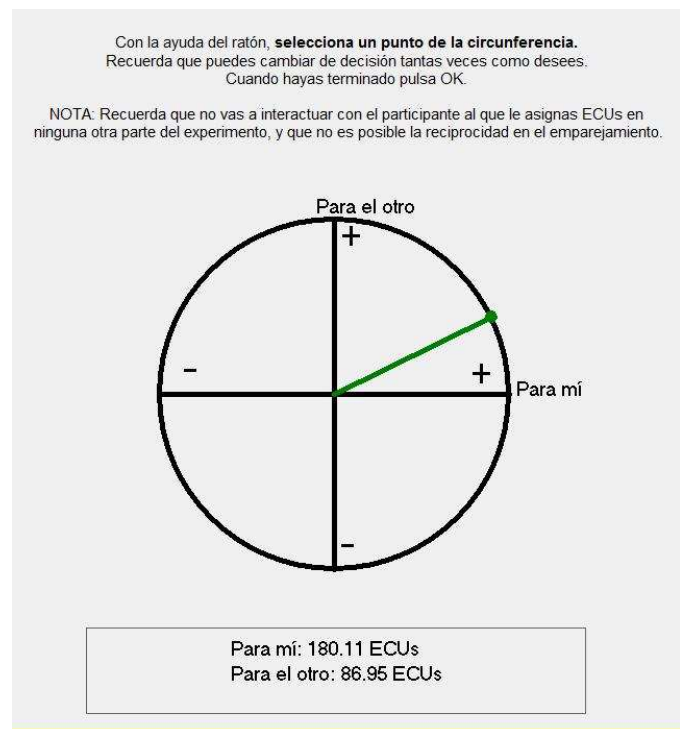

\section{Translation:}

With the help of the mouse, choose a point on the circle. Remember that you can change the decision as many times as you want.

When you are finished press OK.

NOTE: Remember that you will not interact with the participant to whom you assign ECU in any other part of the experiment and that reciprocity between matched pairs is not possible.

For myself: $180.11 \mathrm{ECU}$

For the other: $86.95 \mathrm{ECU}$

Figure 2. Social value orientation circle test

200 ECU to oneself and 0 ECU to the other; an angle of 90 degrees is interpreted as altruistic as it gives 0 to oneself and 200 to the other. Generally, between 0 and 90 degrees an increasing angle is interpreted as increasing pro-sociality. A negative angle, which reduces the earnings of the other at some cost to oneself, identifies competitiveness 7

In the experiment the circle appeared on participants' computer screens. Participants received computerized instructions about how to make the decision and had ample opportunity to practice 8 Decisions in the circle-test had pecuniary consequences. The chosen ECU translated into money earnings at the exchange rate of $100 \mathrm{ECU}$ to $€ 1$. As matched others were random and anonymous, SVO 1 measures the social value orientation towards generalized others. Subjects were not informed about the decision of 'their' others in the circle-test until the very end of the session.

Parts 3 and 4: DAM and SDG. Our main interest lies in potential effects of market experience on efficient cooperation. In order to avoid too much distraction between the two parts, participants received the instructions for DAM and SDG together. After having read the

\footnotetext{
${ }^{7}$ For an extensive discussion of the concept and measurement of social value orientation, see, e.g., Van Lange (1999) and Murphy et al. (2011).

${ }^{8}$ Each participant, made a social value orientation decision with respect to another anonymously and randomly chosen participant in the lab. Importantly, the alter-participant does not make a decision towards the egoparticipant but toward yet another randomly chosen participant. This was known to the participants and excludes (anticipated) reciprocity considerations.
} 
instructions and before the start of DAM participants had to answer comprehension questions about both DAM and SDG.

In the two market treatments participants interacted in the DAM for 18 rounds and in each round there were the same three sellers and five buyers. Each seller was endowed with two units of a good which could be sold to the buyers and each buyer could buy up to two units. Thus, total market supply was six units and total market demand ten units, implying that buyers were on the long side of the market. We chose to give every trader two units (instead of only one) to create a thicker market with more trades without having to increase the number of traders. The production costs of each of the units of the three sellers was 10 and the redemption value of each unit of the five buyers was 100. This gives a so-called box design (Holt et al., 1986). We chose that design because it creates distinct market experiences for agents on respectively the short and the long side of the market.

The earnings from the sale of a unit were equal to the price at which the unit was traded, while the earnings from the purchase of a unit were equal to 100 minus the price at which the unit was traded. Not traded units created neither gains nor losses. The price was allowed to have any integer value between 10 and 95 (inclusive). We chose this upper bound on the trading price to break indifference and facilitate trade 9 More formally, in each round the earnings of a buyer in the market were given by

$$
u= \begin{cases}\left(100-p_{x}\right)+\left(100-p_{y}\right) & \text { if the buyer buys one unit at price } p_{x} \\ & \text { and another unit at price } p_{y} \\ \left(100-p_{z}\right) & \text { if the buyer buys one unit at price } p_{z} \\ 0 & \text { if the buyer does not buy any unit }\end{cases}
$$

and the profit of a seller is given by

$$
\pi= \begin{cases}\left(p_{x}-10\right)+\left(p_{y}-10\right) & \text { if the seller sells one unit at price } p_{x} \\ \left(p_{z}-10\right) & \text { and another unit at price } p_{y} \\ 0 & \text { if the seller sells one unit at price } p_{z}\end{cases}
$$

where $p_{x}, p_{y}, p_{z} \in\{10,11, \ldots, 94,95\}$.

\footnotetext{
${ }^{9}$ In the experimental literature sometimes trading bonuses are used instead. We did not do that because it changes the competitive equilibrium prediction (see, e.g., Davis and Holt, 1993; ;oussair and Tucker, 2013).
} 
Depending on the market role, a trader knew her own production cost or redemption value, but did not know those of the other traders. Hence, traders did not receive any information about the earnings of the other market participants. Participants were informed about the total number of buyers and sellers active in the market. We chose this information regime because it has been shown to minimize fairness considerations and to facilitate converge to the competitive equilibrium (Smith, 1976; Holt et al., 1986). In the competitive equilibrium all six units are traded at price 95. Sellers' per unit equilibrium profit is $85(95-10)$ and buyers' per unit equilibrium earnings are $5(100-95)$.

In the DAM traders had to follow particular trading rules equivalent to those used in previous double-auction market experiments:

1. Buyers make purchase offers and sellers make sale offers. An offer by a buyer consists in offering a price at which to buy a unit. An offer by a seller consists in offering a price at which to sell a unit.

2. Only the highest purchase offer and the lowest sale offer are the so-called pending prices at which transactions can take place.

3. A transaction takes place automatically if the price of a purchase (sale) offer that is made is equal or higher (lower) than the price of the pending sale (purchase) offer. The transaction price is always the pending price (regardless of the offer that leads to the transaction). A transaction also takes place if a pending purchase (sale) offer is accepted by a seller (buyer).

4. New price offers have to be improvements. That is, a new purchase (sale) offer has to be higher (lower) than the pending purchase (sale) offer.

5. If a transaction takes place the market clears and any purchase offer or sale offer in the feasible price interval is possible again.

6. The units of the good are traded one by one. That is, traders cannot make offers for or trade several units at a time.

The DAM was conducted for 18 consecutive periods with the same fixed group of eight participants. Participants in a market did not know who they were matched with. A trading period ended after three minutes or when no trades were possible any more. All participants were informed about their role in the market, buyer or seller, at the beginning of the 18 periods of the DAM and were also told that these roles would stay constant throughout these periods. During the DAM buyers and sellers could see the purchase and sale offers and transaction prices but not the identities behind the offers and transactions. Hence, traders were also not able to track 
others' individual behavior across market periods. When a trade took place, traders received information only about their own earnings. At the end of a trading period each trader received information about his or her total earnings in that period.

Immediately, after the 18 periods of the DAM, participants played six periods of the SDG. The SDG was a two-person linear public goods game and pairs stayed the same throughout the game. In each period each participant was endowed with 50 ECU and had to distribute them between a private and a public account. We used an MPCR $=0.9$ so that for every unit that a player put into the public account both the player in question and the partner's player obtained 0.9 units 10 Formally, in each period of the SDG, earnings of a participant $i$ were given by

$$
w_{i}=50-g_{i}+0.9\left(g_{1}+g_{2}\right)
$$

with $g_{i}(i=1,2)$ being player $i$ 's amount allocated to the public account. In the SDG, contribution decisions were made simultaneously. After each participant had made his/her decision each pair received information about decisions in their pair; that is, own contribution, other's contribution, own earnings, and other's earnings.

As already mentioned above, the matching in the SDG differed between the two market treatments, called market-partners and market-strangers. In the market-partners (henceforth, MP) treatment each participant was matched with one of the other seven participants from the same DAM. Matching was done such that it led to two pairs of buyers, one pair of sellers and one pair consisting of a buyer and a seller. Specifically, the instructions specified: "You will be matched with another buyer (seller) with whom you have interacted in the market." Hence, in the SDG, participants knew the market role of the other participant they have been paired with. They were also told that they would stay matched with the same person during the six periods of the SDG. In this way we created one pair of prospective market-losers (buyer pairs), two pairs of prospective market-winners (seller pairs) and one pair consisting of a prospective market-loser and market-winner (mixed pairs).

In the market-strangers (henceforth, MS) treatment each participant in a DAM was matched with one other participant from another DAM. Here the instructions specified: "You will be

\footnotetext{
${ }^{10}$ We used a two-person version of the public goods game because it allowed us to obtain a relatively large number of independent observations at relatively low costs. We chose the MPCR on the basis of two pilot sessions with stand-alone two-person linear public goods game experiments with the same subject pool as in the reported experiments. In these sessions we observed that an MPCR $=0.9$ lead to efficiency levels of about 50 percent, leaving about the same room for efficiency improvement and worsening, respectively, in the market experiments.
} 
matched with another buyer (seller) from another market with whom you have not interacted in the market." In this case the matchings for the SDG were made using participants from two different DAMs. The sixteen subjects were matched in a way that led to four buyer-pairs, two seller-pairs, and two mixed pairs. Like in MP, market roles were known and the described matchings stayed the same for all periods of the SDG and participants were informed about this. Figure 3 provides a graphical representation of the matchings in MP and MS, respectively.

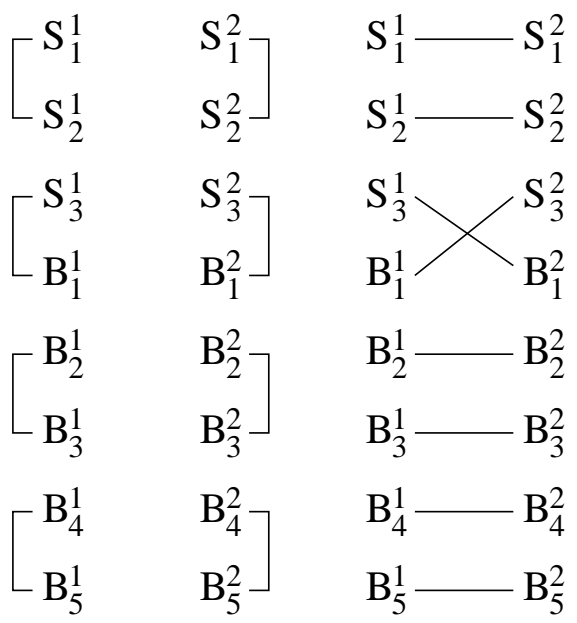
(a) MP
(b) MS

Note: $S_{i}^{m}\left(B_{j}^{m}\right)$ denotes seller (buyer) $i(j)$ in market $m$.

Figure 3. Matchings in the SDG in market-partners (MP) and market-strangers (MS)

Parts 5 and 6: SWB 2 and SVO 2. After the SDG, in SWB 2 we again recorded participants' response to the subjective well-being question shown in Figure 1 and in SVO 2 participants again made decisions in the social value orientation circle-test 11 In SVO 2 each participant made an allocation decision with respect to him/herself and another anonymously and randomly chosen participant whom s/he did not interact with in any of the previous parts. As in SVO 1, to avoid (anticipated) reciprocity, the matched participant did not make a decision towards the deciding participant but towards another not previously matched participant. Again, subjects were informed about the matching procedure but did not receive information about the decision of 'their' paired others until the very end of the session.

\footnotetext{
${ }^{11}$ Alternatively, we could have placed SWB 2 and SVO 2 directly after the DAM. We did not do that because it could have influenced behavior in the the SDG, which is our main variable of interest.
} 
Parts 7: sSDG. After SVO 2 a surprise restart of the SDG was announced and participants played an additional 12 periods of the SDG. Each participant was informed that they would be matched with the same person as in the first six periods. We introduced the surprise restart to see if any effects on the efficiency of cooperation due to market experience would be longer lasting and survive the re-setting commonly observed in public goods games with surprise restarts (see, e.g., Andreoni, 1988; Croson, 1996).

\subsection{Control Treatments}

We conducted two control treatments. First, in order to have a benchmark to which we could compare contribution behavior in the social dilemma game, we have run a treatment where participants played a SDG without having experienced a market before. In that treatment, except for that there was no DAM, all features of the design were exactly the same as in the above described market treatments. That is, the sequence of events was the same as depicted in Table 1 (except for item 3.) and each participant was matched with the same other person both in the first six and the second 12 periods of the SDG. We call this treatment OSDG (standing for 'Only' SDG).

Second, as we will see in the results part, there are - as intended - large earnings differences between sellers and buyers in the DAM. To control for potential effects of these differences on contribution behavior in the SDG, we conducted another control treatment. In this treatment, participants received lump-sum payments before the start of the SDG. Each participant was in one of four payment conditions. The conditions differed in respect to the received lump-sum payment, which corresponded respectively to the average buyer and seller earnings in MP and MS. We will call this treatment OSDG-I(ncome). Except for the lump-sum payments before the start of the SDG, this treatment was the same as the other control treatment. It was also equivalent to the market treatments in terms of average pre-SDG earnings, except that participants did not earn these payments through market interactions. The instructions for the SDG in this control treatment were kept as close as possible to those in DAM. In particular, regarding the lump-sum payments and the matching with another participant in the SDG the instructions said: "You have been assigned initial earnings of $X$ ECU. The other group member is also assigned some initial earnings. The assignments to you and the other group member are not necessarily the same. You and the other group member will receive this amount independently of what occurs 
during the experiment."12 We deliberately used a vague phrasing regarding the earnings of the other group member because in DAM participants also only knew their own market earnings for sure, whereas they did not receive information about the other group member's market earnings. We describe the exact lump-sum earnings and corresponding matchings in OSDG-I when we discuss the results (see Section 6.2.1).

\section{Experiment Procedures}

In total 512 subjects participated in our experiment. We ran three sessions with treatment OSDG, three with treatment OSDG-I, three with the market-partners treatment (MP) and four with the market-strangers treatment (MS). We have data from 64 subjects in OSDG, 144 in OSDG-I, 112 in market-partners in 14 separate markets, and 192 in market-strangers in 24 separate markets. Hence, for OSDG we have 32 statistically independent observations (i.e., matched pairs of participants in the SDG) and for OSDG-I 72, which are distributed over six different conditions with 12 independent pairs per condition (see Section 6.2.1 for details). For market-partners we have 56 pairs in the SDG (28 buyer-pairs, 14 seller-pairs, 14 mixed-pairs) organized in 14 independent matching groups (markets) and for market-strangers we have 96 pairs in the SDG (48 buyer-pairs, 24 seller-pairs, 24 mixed-pairs) organized in 12 independent matching groups (twins of markets across which participants are matched in the SDG).

In the two market treatments, each participant's role (buyer or seller) was fixed for the duration of the session. General instructions were read aloud at the start of each session. Instructions for the different parts were given on-screen and participants could read them at their own pace 13 Participants could ask questions by raising a hand. All questions were answered in private.

The experiments were conducted at the LINEEX lab at the University of Valencia using the z-tree program of Fischbacher (2007). Each session involved one of the treatments and no one could participate in more than one session. Performance-based earnings were counted in ECU and total earnings consisted of the accumulated earnings across all parts. Each 100 ECU were worth $€ 1$. Participants did not receive a show-up fee. At the end of a session participants were privately paid out their earnings in cash. Average earnings were $€ 18.50$ for the OSDG, $€ 33.00$

\footnotetext{
${ }^{12}$ The actual amount of $X$ ECU used in the instructions depended on the condition the participant was assigned to (see below).

${ }^{13}$ The main reason for not reading aloud all instructions was that this would have revealed information about the potential earnings of buyers and sellers in DAM, which we wanted to avoid.
} 
for OSDG-I, and $€ 29.50$ for the market treatments. OSDG and OSDG-I sessions took about 90 minutes and sessions with market treatments took about 120 minutes.

\section{$5 \quad$ Research Hypotheses}

Our main focus is on understanding to what extent participation in a competitive market has repercussions for the efficiency achieved in subsequent social dilemma games. In addition, we also study the effects of market participation on our measurements of subjective well-being and social value orientation.

We formulate our hypotheses inspired by some of the concepts developed by Bowles and Polania-Reves (2012). Two key elements of their conceptual framework are the notion of separability between economic incentives and social preferences and the distinction between state-dependent and endogenous preferences.

Applied to our context separability means that experiences in different spheres of social interaction do not interact with preferences or, more specifically, that the ability to efficiently cooperate in a social dilemma game is independent of preceding market experience. This notion of separability is implied in the view proposed by Smith (1998) that people are able to decouple behavior in small-group exchange from that in anonymous markets. In our experimental environment, the assumption of separability leads to our null hypothesis:

Hypothesis 1. Market experience has an effect neither on the efficiency of cooperation in the SDG nor on subjective well-being or social value orientation.

Alternatively, it has been argued that behavior can depend on the circumstances surrounding the decision situation, which can be captured by the notion of state-dependence 14 In the words of Bowles and Polania-Reyes (2012): "State-dependence arises because actions are motivated by a heterogeneous repertoire of preferences from spiteful to payoff-maximizing to generous, for example, the salience of which depends on the nature of the decision situation" (p. 373) 15 Our alternative hypotheses are formulated in terms of state-dependence of behavior in the SDG.

\footnotetext{
${ }^{14}$ In the framework of Bowles and Polania-Reyes (2012) the term endogenous preferences is used in relation to processes with effects that persist in the long-run, typically as the result of a process of cultural transmission. In the context of our study, the effects we focus on can be better captured in terms of state-dependence.

${ }^{15}$ An example of how state-dependence could be incorporated into a formal model of social preferences is the general model of Charness and Rabin (2002). This two-person model has a more standard part with own and other's payoff and also incorporates a particular parameter that is said to be set to 1 when the decision-maker thinks that the counter-part is misbehaving while it is set to 0 when the counter-part is not misbehaving. The state is whether the counter-part is misbehaving or not and this gives rise to a repertoire of two different social preferences.
} 
The general alternative to our null hypothesis is that behavior will be state-dependent in the sense that market experience will affect subsequent cooperation. Moreover, state-dependence may affect behavior in different ways along two dimensions. First, market interaction as such may affect behavior in the subsequent SDG in different directions. The effect could be to increase cooperation, in accordance with the idea of doux commerce of Montesquieu (1748) or it could be negative, in line with the social criticism of Engels (1845).

Second, as advanced in the introduction, state-dependence could lead to variations in reactions depending on the type of market experience. In particular, having been on the short or the long side of the market and having been paired with somebody from the own or the other side may lead to different reactions. Similarly, cooperation may be affected differently depending on whether or not one is paired with somebody one has previously competed with for scarce resources on the same market.

We also relate our analysis to our previous work in Brandts et al. (2009) where we found that being on the long side of a triadic exchange relation leads to lower subjective well-being and less social value orientation, measured after the exchange relation had finished. The issue here is whether possible effects of market experience on cooperation can be related to effects on subjective well-being and social value orientation.

We formulate alternative hypotheses in terms of the effects on cooperation. Our analysis of subjective well-being and social value orientation will be part of a more detailed discussion of these alternatives.

Hypothesis 2. Market participation as such will affect subsequent cooperation.

Hypothesis 2 is two-sided, reflecting the existence of conflicting ideas on the effects of market participation, as discussed above. In evaluating it we will simply compare SDG behavior with and without preceding market interaction.

Importantly, our design allows us to make a number of more specific comparisons of interest. First, we can compare market-strangers with market-partners. As mentioned in the introduction, these two treatments are meant to capture the distinction between more local market interaction and more distant market interaction. One may expect the different kinds of relations in the market to affect participants' attitudes towards the subsequent interaction. In market-partners the experience of having competed with each other for scarce resources may on the one hand inject some sense of social closeness and thus increase cooperation, but on the other hand it may also induce a competitive state that could be detrimental to efficient cooperation. Market- 
strangers may create an atmosphere of more anonymity and disconnectedness. Whether this will have a positive or negative effect on cooperation is an open question.

Second, we can hold the market-strangers vs. market-partners distinction constant and compare behavior in different matchings of participants who have been on the same or on opposite sides of the market. In this case, the issue is whether pairs of participants who both have been assigned to the long side of the market, market-losers, cooperate better or worse than pairs with other market experiences and pairs with no market experience. It is not easy to gauge what the effects will be. Given that market-losers earn little income, one may expect pairs of them to cooperate more efficiently out of the need of compensating for low earnings in the market. Also, a sense of solidarity between them may lead to better cooperation. However, market experience could also have a negative effect on market-losers by depleting their trust in others or triggering spiteful behavior. Market-winners have a good experience, at least in terms of earnings, which may on the one hand make it easier to cooperate but on the other hand also here a competitive state of participants may affect cooperation negatively. The latter may also occur because of satisficing effects (Simon, 1956) when market-winners have earned already sufficiently much in the market interactions.

Under separability none of these comparisons should exhibit significant differences. However, as just described there are reasons suggesting opposing forces under the different circumstances and it is an empirical question, which one - if any - will prevail. We formulate this in our second general two-sided alternative hypothesis.

Hypothesis 3. The type of experienced market participation will affect subsequent cooperation in different ways.

This hypothesis can be refined into a number of specific questions pertaining to how market participation affects the efficiency of post-market cooperation of different pairs of individuals:

(A) Pairs of individuals who had interacted in the same market (market-partners) compared to pairs of individuals who had interacted in distinct markets (market-strangers) and to those without market experience? 16

(B) Pairs of individuals who had both been on the favorable side of markets (market-winners) compared to pairs of individuals who had both been on the unfavorable side of markets

\footnotetext{
${ }^{16}$ In this comparison we average the different types of matchings. We leave out the other possible comparison of averages, where we would average for each type of matching across market-partners and market-strangers.
} 
(market-losers) and compared to pairs of individuals who had been on the opposite side of markets, all three compared between market-partners and market-strangers?

(C) Pairs of individuals who had both been on the favorable side of markets compared to pairs of individuals who had both been on the unfavorable side of markets and compared to pairs of individuals who had been on the opposite side of markets, all three compared within market-partners and market-strangers?

Brandts et al. (2009) found that experiencing competitive rivalry in fixed triads had a negative impact on the experienced well-being of those on the long side of the interaction and a positive impact on those on the short side. Here we study whether this result extends to the case of market interaction in a proper competitive market, and whether it is affected by the distinction between market-partners and market-strangers 17

Hypothesis 4. The type of market participation will affect subjective well-being and social value orientation.

The specific research questions we will investigate in respect to this hypothesis are whether subjective well-being or social value orientation are affected by market participation or by the market side a person is on.

In our set-up, if market participation has a negative effect per se, then social value orientation is expected to be lower towards all market participants. In contrast, if social value orientation responds to income comparisons, as e.g. in Fehr and Schmidt (1999), then social value orientation of those on the short side of the market (market-winners) is expected to increase (or at least not decrease) while that of those on the long side of the market (market-losers) is expected to decrease (to compensate for the relative income disadvantage). In addition, we will be able to investigate the effect of the market-partners vs. market-strangers distinction.

\section{Results}

In this section, we first briefly report on market behavior to see if our markets indeed converge to asymmetric equilibrium outcomes as intended. Thereafter, we zoom in to our main research

\footnotetext{
${ }^{17}$ In the mentioned study, it was found for social value orientation that the powerful player in the triad did not change his disposition towards the player who had been chosen more frequently and thus earned relatively much but surprisingly lowered it towards the less frequently chosen and thus low earnings player. Both powerless players lowered their disposition towards others.
} 
question and discuss if and how different market experiences affect behavior in the subsequent social dilemma games. Finally, we discuss the effect of different experiences in the markets and social dilemma games on subjective well-being and social value orientation.

\subsection{Market Behavior}

Figure 4 shows the average transaction price over the 18 trading periods in the two market treatments. As expected, prices in both treatments converge to the highest possible price of 95. Of the total of 4104 possible trades only 7 were not realized and overall efficiency was with $99.8 \%$ virtually optimal. This market outcome leads to very unequal incomes. Using individual data the averages (standard deviations) of earnings are 2672 (277) for sellers and 340 (176) for buyers in the market-partners treatment and 2656 (324) for sellers and 346 (222) for buyers in the market-strangers treatment 18 As expected, neither buyer nor seller earnings significantly

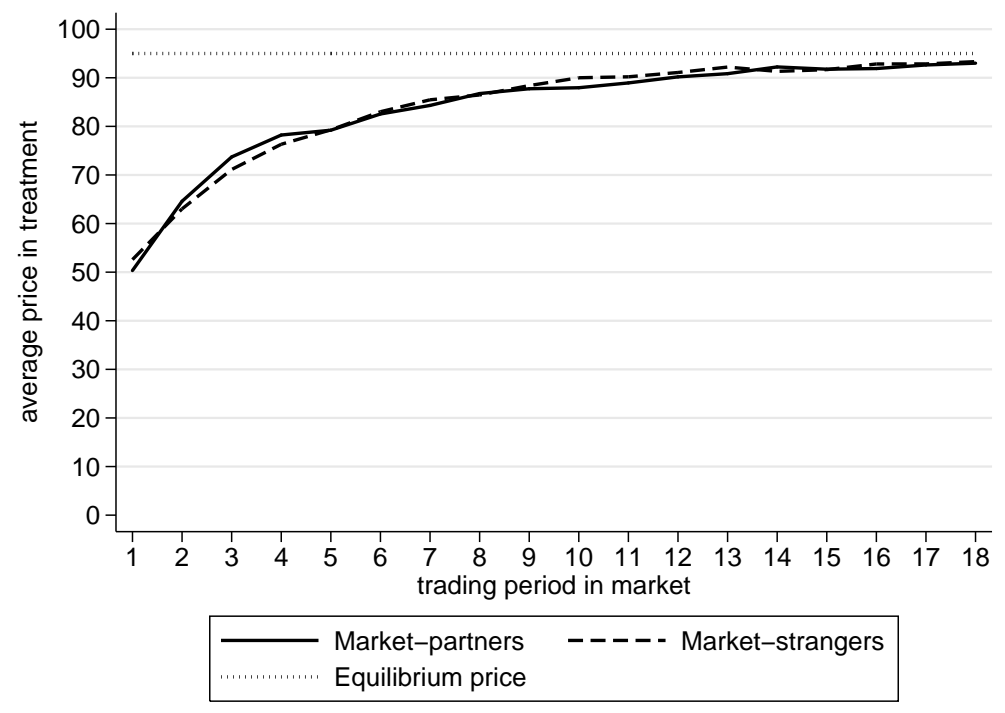

Figure 4. Average trading price dynamics in both market treatments

differ between market-partners and market-strangers treatments (buyer earnings: $p=0.6434$, seller-earnings: $p=0.5371$; MW-tests, 2-sided). We can conclude that our manipulation worked as intended. With the implemented markets we achieved very different market experiences for participants on the long and on the short side of the market, without differences between the two market environments.

\footnotetext{
${ }^{18}$ Note that if there are any pre-existing social preferences they apparently have little effect on the outcome of the market interaction, due to the competitiveness of the institution (see Bolton and Ockenfels, 2000).
} 


\subsection{Behavior in the Social Dilemma Game}

Figure 5 shows mean contributions for each of the 18 rounds in the SDG of the two market treatments and the OSDG treatment. In rounds 1-6 there is a clear ranking of the treatments visible. Contributions in the market-strangers treatment are above those in the control treatment without market interaction (except for the last round), which in turn are above the ones in the market-partners treatment. In rounds 7-18 contributions in the market-strangers and OSDG treatments are similar, while in the market-partners treatment they are clearly below those of the other two treatments 19

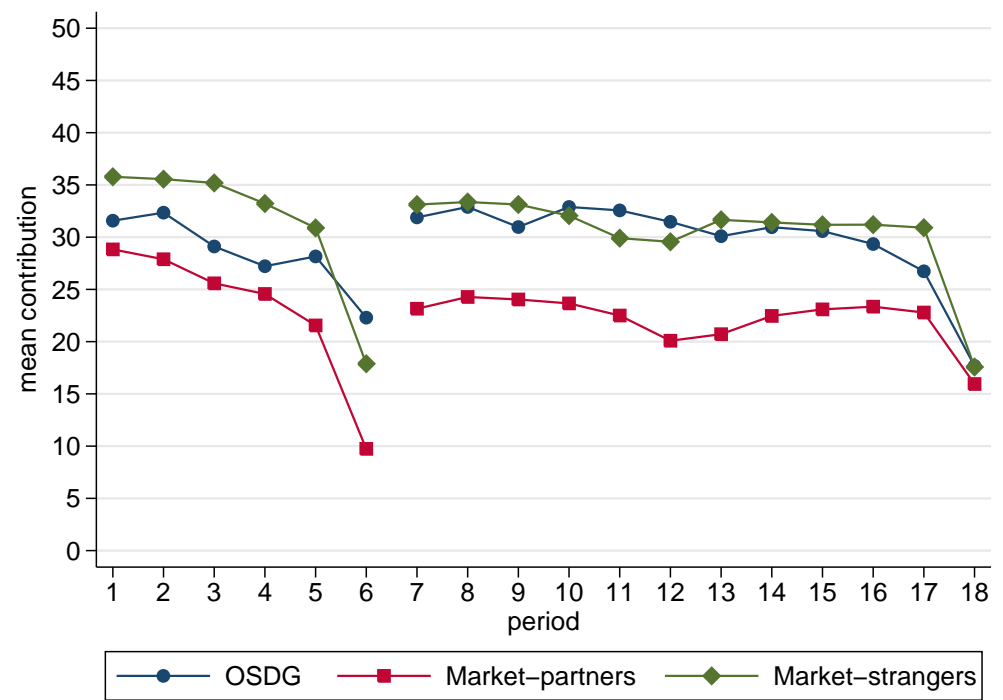

Figure 5. Dynamics of average contributions in OSDG and the two market treatments

In our statistical analysis we treat our three main research questions one by one. Using regression analysis, Table 2 reports tests on differences in contributions across treatments, aggregated over trader matchings and respectively all periods, periods 1-6, and periods 7-18 20 In all reported specifications contributions are regressed on dummy variables identifying the market-partners and market-strangers treatment, respectively. Treatment OSDG is the refer-

\footnotetext{
${ }^{19}$ In all treatments we observe the often documented end-of-game effect, both in round 6 and in round 18. It should also be noted that the contributions in all three treatments exhibit a restart effect, first reported in Andreoni (1988); that is, in round 7 contribution levels jump up to levels similar to those of rounds 1-5.

${ }^{20}$ In the main text, we report statistical tests using OLS regression analysis based on individual contributions with standard errors corrected for dependence of observations within pairs in OSDG, within individual markets in market-partners, and within pairs of interlinked markets in market-strangers. The results are consistent with those of non-parametric tests, which are reported in Appendix A.1.1
} 
ence category 21 Specification (1) reports the results for all 18 periods and shows that compared to OSDG contributions in market-partners are 6.92 points lower $(p=0.036)$. Corroborating the visual impression from Figure 5. An $F$-test comparing contributions in market-partners and market-strangers shows that contributions are highly significantly lower in the former than in the latter (diff.: 8.298, $p<0.001$ ). There is no statistically significant difference between contributions in market-strangers and OSDG $(p=0.622)$. Specifications $(2)$ and $(3)$ in Table 2 show a very similar picture for rounds 1-6 and 7-18 separately. In market-partners contributions are significantly lower than in the other treatments. Interestingly, as already suggested by Figure 5, comparing contributions in rounds 1-6 and rounds 7-18 indicate that the negative effect in market-partners does not vanish, but is rather reinforced over time.

Table 2. Tests for differences in contributions in the social dilemma game across treatments (aggregated over trader matchings)

\begin{tabular}{|c|c|c|c|}
\hline \multirow{3}{*}{ Specification } & \multicolumn{3}{|c|}{ dep. var.: contribution to public good } \\
\hline & $(1)$ & $(2)$ & $(3)$ \\
\hline & all periods & periods $1-6$ & periods $7-18$ \\
\hline \multirow[t]{2}{*}{ Market-partners } & $-6.919^{* *}$ & $-5.425^{*}$ & $-7.665^{* *}$ \\
\hline & $(3.228)$ & $(3.249)$ & $(3.424)$ \\
\hline \multirow[t]{2}{*}{ Market-strangers } & 1.379 & 2.968 & 0.585 \\
\hline & $(2.779)$ & $(2.734)$ & $(2.990)$ \\
\hline Constant (OSDG) & $\begin{array}{c}29.375^{* * *} \\
(2.640)\end{array}$ & $\begin{array}{c}28.451^{* * *} \\
(2.589)\end{array}$ & $\begin{array}{c}29.837^{* * *} \\
(2.815)\end{array}$ \\
\hline$R^{2}$ & 0.037 & 0.039 & 0.036 \\
\hline \multirow[t]{2}{*}{$N$} & 6624 & 2208 & 4416 \\
\hline & \multicolumn{3}{|c|}{ MP vs MS } \\
\hline \multirow{2}{*}{$\begin{array}{l}F_{(1,57)} \\
p \text {-value }\end{array}$} & 16.37 & 15.21 & 14.14 \\
\hline & 0.0002 & 0.0003 & 0.0004 \\
\hline
\end{tabular}

Hence, we find that market participation can be harmful for cooperation, but that it is not market experience per se. The efficiency of cooperation is negatively affected when one has to cooperate with people with whom one has previously interacted in the market. Not having competed in the same market - something that can be seen as a more anonymous environment -

\footnotetext{
${ }^{21}$ For all reported regressions here and later in the paper we have also run specifications adding period dummies to control for time trends and Tobit instead of OLS to correct for censoring of contributions by 0 and 50 . The results are qualitatively virtually the same and reported in Appendix A.1.2.
} 
leads to higher cooperation than having had to compete with each other. The differences survive the restart after the first six rounds and even become somewhat stronger. We summarize this answer to our research question pertaining to overall cooperation levels in the following result.

Result 1. Overall, market participation harms efficient cooperation when agents previously competed in the same market and has no effect when agents previously competed in different markets.

We next move to the question, whether the aggregate differences just discussed are similar for the different trader matchings or whether they are driven by specific matchings. Recall that in buyer matchings the two interacting participants both have had a difficult time in securing trades and have obtained low earnings. In seller matchings participants have technically also competed for trades but from a very comfortable position and have obtained high earnings. Finally, mixed matchings bring together very different market experiences and earnings levels.

Figure 6 shows average contribution levels for the three distinct kinds of matchings in the two market treatments as well as in the stand-alone OSDG. Figure 6a depicts contributions in buyer pairs and clearly shows that buyers do worst in market-partners in all periods (expect the very last one), whereas contributions are similar in market-strangers and OSDG. A similar picture emerges for seller pairs (Figure 6b), specifically regarding behavior in market-partners. Their contributions are clearly below those of sellers in market-strangers and of agents in OSDG. Interestingly, seller pairs having experienced the market-strangers environment tend to contribute more than agents in OSDG without market experience. Finally, for mixed pairs, Figure 6c shows little differences across treatments.

Table 3 reports regression analysis, comparing contributions of the three different trader matchings separately across the market treatments and OSDG, aggregated over all periods. Again, OSDG is the reference category. The results shown in the table corroborate the visual impressions gained from Figure 6. For buyer matchings, contributions in market-partners are 9.68 points lower than in OSDG and 8.71 points lower than in market-strangers. Both differences are statistically significant ( $p=0.013$ and $p=0.008$, respectively). For seller pairs we also find that contributions in market-partners are (marginally) significantly lower than in respectively OSDG (diff.: $-8.32, p=0.055$ ) and market-strangers (diff.: $-14.22, p<0.001$ ). In contrast, comparing behavior of seller pairs in market-strangers to behavior in OSDG, we see that they tend to contribute even more with than without market experience (diff.: $5.90, p=0.078$ ). Finally, for the mixed matchings there are no statistically significant differences across treatments $(p \geq 0.652)$. 


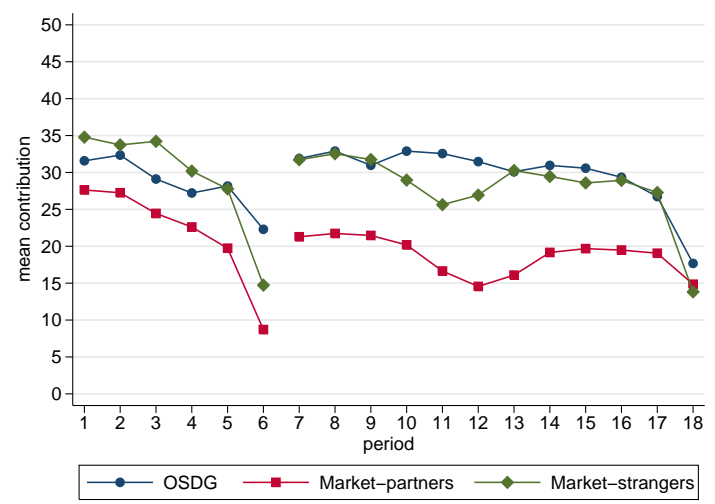

(a) Buyer pairs \& OSDG

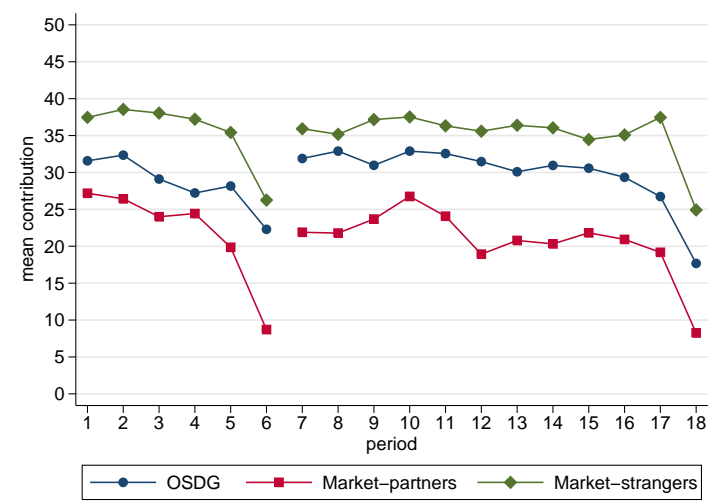

(b) Seller pairs \& OSDG

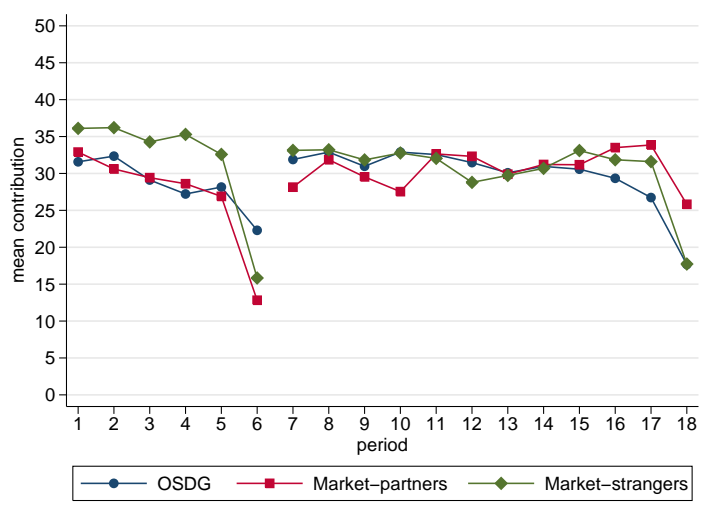

(c) Mixed pairs \& OSDG

Figure 6. Average contributions over rounds in the three treatments by different trader matchings

By and large, the differences identified when taking all periods into account, are also found when looking at periods 1-6 and periods 7-18 separately (see Table 4). For buyer pairs contributions are lower in market-partners than in both market-strangers and OSDG already in periods 1-6 (diff.: $-7.51, p<0.010$ and diff.: $-6.72, p=0.056$, respectively). These differences do not vanish but rather increase in the later periods 7-18 (diff.: $-9.31, p=0.012$ and diff.: -11.16 , $p=0.010$, respectively). When comparing market-strangers and OSDG, no significant differences in contributions of buyer pairs are found, neither in the early nor the later periods. For seller pairs in periods 1-6 contributions are lower in market-partners than in market-strangers (diff.: -13.72) and OSDG (diff.: -6.68), which is statistically highly significant in the former $(p<0.001)$ but fails to be statistically significant in the latter $(p=0.112)$ comparison. For the later periods 7-18 both differences increase and become statistically (marginally) significant (diff.: $-14.47, p=0.001$ and diff.: $-9.14, p=0.056$, respectively). seller pairs contribute more 
Table 3. Tests for differences in contributions in the social dilemma game across treatments by trader matchings (all periods)

\begin{tabular}{|c|c|c|c|}
\hline \multirow{3}{*}{ Specification } & \multicolumn{3}{|c|}{ dep. var.: contribution to public good } \\
\hline & $(1)$ & $(2)$ & $(3)$ \\
\hline & buyer pairs & seller pairs & mixed pairs \\
\hline \multirow[t]{2}{*}{ Market-partners } & $-9.678^{* *}$ & $-8.319^{*}$ & -0.000 \\
\hline & $(3.768)$ & $(4.254)$ & $(4.749)$ \\
\hline \multirow[t]{2}{*}{ Market-strangers } & -0.970 & $5.899^{*}$ & 1.557 \\
\hline & $(3.126)$ & $(3.288)$ & $(3.433)$ \\
\hline \multirow[t]{2}{*}{ Constant (OSDG) } & $29.375^{* * *}$ & $29.375^{* * *}$ & $29.375^{* * *}$ \\
\hline & $(2.640)$ & $(2.640)$ & $(2.640)$ \\
\hline$R^{2}$ & 0.045 & 0.073 & 0.001 \\
\hline \multirow[t]{2}{*}{$N$} & 3888 & 2520 & 2520 \\
\hline & \multicolumn{3}{|c|}{ MP vs MS } \\
\hline \multirow{2}{*}{$\begin{array}{l}F_{(1,57)} \\
p \text {-value }\end{array}$} & 7.56 & 13.51 & 0.12 \\
\hline & 0.0080 & 0.0005 & 0.7316 \\
\hline
\end{tabular}

in market-strangers than agents in OSDG, especially in the early periods (periods 1-6: diff.: 7.04, $p=0.038$; periods 7-18: diff.: 5.33, $p=0.131$ ). For seller-buyer pairs contributions significantly differ neither in periods $1-6$ nor in periods 7-18 $(p \geq 0.289)$. We briefly summarize in our next result.

Result 2. The observed adverse effects of market experience on efficient cooperation in marketpartners can be attributed both to market-losers (buyer pairs) and market-winners (seller pairs). For seller pairs market experience in market-strangers tend to positively affect contribution behavior. There is no effect of market experience on contributions in mixed pairs.

The result indicates that having experienced together the severity of competition in the experimental market negatively affects agents' ability to successfully cooperate. Importantly, the effect does not vanish over time and is present for both partnerships of market-losers and partnerships of market-winners. The fact that pairs from both market sides are affected makes it hard to explain the lower contributions purely with different income levels attained in the market. Interestingly, market-winners in the more socially distant market-strangers treatment are able to increase contributions relative to the control treatment. Hence, market experience may be beneficial for cooperation provided the market experience is positive and not with the 
Table 4. Tests for differences in contributions in the social dilemma game across treatments by trader matchings (periods 1-6 \& periods 7-18)

\begin{tabular}{|c|c|c|c|}
\hline \multicolumn{4}{|c|}{ Periods 1-6 } \\
\hline \multirow{3}{*}{ Specification } & dep. var.: & contribution & public good \\
\hline & $(1)$ & $(2)$ & $(3)$ \\
\hline & buyer pairs & seller pairs & mixed pairs \\
\hline \multirow[t]{2}{*}{ Market-partners } & $-6.721^{*}$ & -6.682 & -1.576 \\
\hline & $(3.447)$ & $(4.140)$ & $(4.794)$ \\
\hline \multirow[t]{2}{*}{ Market-strangers } & 0.786 & $7.036^{* *}$ & 3.265 \\
\hline & $(3.062)$ & $(3.318)$ & $(3.308)$ \\
\hline Constant (OSDG) & $\begin{array}{c}28.451^{* * *} \\
(2.590)\end{array}$ & $\begin{array}{c}28.451^{* * *} \\
(2.591)\end{array}$ & $\begin{array}{c}28.451^{* * *} \\
(2.591)\end{array}$ \\
\hline$R^{2}$ & 0.031 & 0.073 & 0.010 \\
\hline \multirow[t]{2}{*}{$N$} & 1296 & 840 & 840 \\
\hline & \multicolumn{3}{|c|}{ MP vs MS } \\
\hline \multirow{2}{*}{$\begin{array}{l}F_{(1,57)} \\
p \text {-value }\end{array}$} & 7.18 & 12.78 & 1.14 \\
\hline & 0.0096 & 0.0007 & 0.2895 \\
\hline \multicolumn{4}{|c|}{ Periods 7-18 } \\
\hline \multirow{3}{*}{ Specification } & dep. var.: & contribution & public good \\
\hline & $(1)$ & $(2)$ & $(3)$ \\
\hline & buyer pairs & seller pairs & mixed pairs \\
\hline \multirow[t]{2}{*}{ Market-partners } & $-11.156^{* * *}$ & $-9.138^{*}$ & 0.788 \\
\hline & $(4.173)$ & $(4.681)$ & $(5.069)$ \\
\hline \multirow[t]{2}{*}{ Market-strangers } & -1.848 & 5.331 & 0.703 \\
\hline & $(3.380)$ & $(3.479)$ & $(3.782)$ \\
\hline \multirow[t]{2}{*}{ Constant (OSDG) } & $29.837^{* * *}$ & $29.837^{* * *}$ & $29.837^{* * *}$ \\
\hline & $(2.815)$ & $(2.816)$ & $(2.816)$ \\
\hline$R^{2}$ & 0.054 & 0.073 & 0.000 \\
\hline \multirow[t]{2}{*}{$N$} & 2592 & 1680 & 1680 \\
\hline & \multicolumn{3}{|c|}{ MP vs MS } \\
\hline \multirow{2}{*}{$\begin{array}{l}F_{(1,57)} \\
p \text {-value }\end{array}$} & 6.67 & 11.53 & 0.00 \\
\hline & 0.0124 & 0.0013 & 0.9862 \\
\hline
\end{tabular}

same people one has to solve the social dilemma with. This seems consistent with the indirect evidence of a positive effect of anonymous market integration on pro-social behavior provided in Camerer and Fehr (2004). 
In the following we test for the observed differences in contributions between different trader pairings, within each market treatment. Table 5 reports the results of $F$-tests based on regression analysis for contributions aggregated over all periods using dummy variables for respectively buyer pairs, seller pairs, and mixed pairs, with treatment OSDG being the reference category 22

Table 5. Tests for differences in contributions in the social dilemma game between trader matchings within market treatments (all periods)

\begin{tabular}{lcc}
\hline \hline & Market-partners & Market-strangers \\
\hline \multirow{2}{*}{ diff. contributions } & \multicolumn{2}{c}{ buyer pairs vs. seller pairs } \\
\cline { 2 - 3 }$F$ & -1.359 & -6.869 \\
$p$-value & 0.09 & 5.77 \\
& 0.7624 & 0.0207 \\
diff. contributions & buyer pairs vs. mixed pairs \\
\cline { 2 - 3 }$F$ & -9.678 & -2.527 \\
$p$-value & 4.32 & 0.62 \\
& 0.0433 & 0.4356 \\
diff. contributions & seller pairs vs. mixed pairs \\
$F$ & -8.319 & 4.342 \\
p-value & 2.58 & 2.30 \\
\hline Note: $F_{1,45}\left(F_{1,43}\right)$ for market-partners (market-strangers).
\end{tabular}

For the market-partners treatment we observe that buyer and seller pairs do not contribute differently $(p=0.7624)$ and that both contribute less than mixed trader pairs. The latter difference is statistically significant for buyer pairs $(p=0.0433)$ but only close to marginal significance for seller pairs $(p=0.1150)$. For the market-strangers treatment we find that pairs of market-winners (seller pairs) contribute more than market-losers (buyer pairs) and mixed trader pairs. The difference is statistically significant for the former comparison $(p=0.0207)$ but not for the latter $(p=0.1365) 23$ We summarize the findings in our next result.

Result 3. With a joint market experience (market-partners) both market-loser pairs and marketwinner pairs contribute similarly and both (tend to) contribute less than mixed pairs. In markets without a joint experience (market-strangers) pairs of market-winners (tend to) contribute more than pairs consisting of market-losers or mixed pairs.

\footnotetext{
${ }^{22}$ For convenience we report here only the comparison results. The whole regression table can be found in Appendix A.1.2. Table A.16

${ }^{23}$ The results are similar when looking at periods 1-6 and 7-18 separately and reported in Appendix A.1.2 Tables A.19 and Tables A.20
} 


\subsubsection{Controlling for the Effect of Income Differences}

An inherent property of markets with a short and a long side is that market opportunities and thus earnings are unequal. We deliberately implemented such markets because it reflects important markets in the field and because it allows us to study whether behavior in a social dilemma situation differs between market-losers and market-winners. Buyers and sellers in our markets therefore ended up with very different earnings after the market phase and one may hypothesize that the differences we find in the social dilemma game are not due to different market experiences but solely a result of different earnings. In other words, it may be that differences in contributions to the public good are merely (or mostly) a reflection of income effects. The result that in the market-strangers treatment seller pairs, which had high market incomes, cooperate most efficiently indeed points to such a possibility. On the other hand, however, results in market-partners are not consistent with this interpretation as there both seller pairs with high market earnings and buyer pairs with low market earnings cooperate rather inefficiently.

To directly test for income effects we have run the control treatment OSDG-I where participants did not experience a market but had the same average income differences as in our market-partner and market-stranger treatments (cf. Section 3.2 where we describe our experiment design). In Section 6.1, where we discussed behavior in markets, we have seen that in market-partners sellers earned on average 2672 ECU and buyers 340 ECU. In market-strangers the corresponding earnings were $2656 \mathrm{ECU}$ and $346 \mathrm{ECU}$. To control for these income differences, in OSDG-I we assigned participants to the following lump-sum earnings pairs: 340-340, 26722672, 2672-340 to mimic the different matchings in market-partners and 346-346, 2656-2656, 2656-346 to mimic matchings in market-strangers. In the following we explore if SDG contributions of these pairs are in line with the SDG contributions of different matchings observed in the market treatments. Specifically, we are interested if the lump-sum earnings matchings 340-340 and 2672-2672, respectively, can explain the relatively low contributions of respectively buyer and seller pairs in market-partners. Similarly, we are particularly interested in whether lump-sum earnings of 2656-2656 in OSDG-I could explain the relatively high contributions of seller pairs in market-strangers.

To get a first impression Table 6 reports descriptive statistics of contributions over all periods for the different matchings in market-partners, market-strangers, the corresponding matches in OSDG-I, and as a benchmark OSDG. The figures reported in the table already suggest that it is unlikely that the observed differences in contributions are due to different earnings participants 
hold before they interact in the social dilemma game. First, when looking at contributions across different matchings within treatment OSDG-I we see little differences between high, low and mixed earnings pairs (columns 2 and 4 in the table). They range from 29.03 of highearnings pairs 2656-2656 to 33.31 of low-earnings pairs 346-346. Second, the low contributions in buyer and seller pairs in market-partners (19.70 and 21.06, respectively) are not accompanied by low contributions in the corresponding 340-340 and 2672-2672 earnings pairs in OSDG-I, where contributions amount to respectively 33.44 and 32.51 . Third, the relatively high contributions of seller pairs in market strangers (35.27) are not matched with higher than average contributions in the corresponding 2656-2656 earnings pairs in OSDG-I (29.03).

Table 6. Average contributions in the social dilemma game for all treatments by matchings (all periods)

\begin{tabular}{ccccc}
\hline \hline Market-Partners & OSDG-I & Market-Strangers & OSDG-I & OSDG \\
\hline buyer pairs & $340-340$ & buyer pairs & $346-346$ & \\
19.70 & 33.44 & 28.41 & 33.31 & 29.38 \\
$(18.34)$ & $(19.11)$ & $(18.45)$ & 16.67 & $(18.70)$ \\
\hline seller pairs & $2672-2672$ & seller pairs & $2656-2656$ & \\
21.06 & 32.51 & 35.27 & 29.03 & \\
$(18.29)$ & $(18.49)$ & $(17.20)$ & $(18.41)$ & \\
\hline mixed pairs & $2672-340$ & mixed pairs & $2656-346$ & \\
29.38 & 30.38 & 30.93 & 29.46 & \\
$(20.12)$ & $(20.79)$ & $(20.06)$ & $(20.37)$ & \\
Note: Standard deviations in parenthesis. Statistics are based on individual contributions \\
in each period.
\end{tabular}

To statistically test for differences in contributions we conducted regression analysis similar to the ones reported above. Specifically, we regressed contributions on dummy variables representing the different matchings in respectively the market-partners and market strangers treatments and the different corresponding lump-sum earnings matchings in treatment OSDG-I, with OSDG as the reference category. We then used $F$-tests to examine statistically significant differences. In the following we report the main results. The regression table with all tests can be found in Appendix A.1.2, Table A.21.

We first test if contributions significantly differ across different income matchings within OSDG-I as such differences would be a first indication that pre-SDG earning differences affect contributions in the SDG. The descriptive statistics above suggest that this is not the case and the statistical analysis corroborates this impression. Equality of contributions across different lump-sum earnings matchings cannot be rejected neither for those corresponding to the market- 
partners treatment $(p \geq 0.5917)$ nor for those corresponding to the market-strangers treatment $(p \geq 0.3581)$. Second, to explain the lower contributions for buyer and seller pairings in marketpartners with the earnings achieved in the market interactions these contributions should not significantly differ from the contributions of the corresponding 346-346 and 2672-2672 matchings. This is not the case as in both comparisons contributions are significantly lower in marketpartners than in OSDG-I ( $p=0.0026$ and $p=0.0305$, respectively). Finally, we test if the higher seller pairs contributions in market-strangers are the same as contributions in 2656-2656 matchings. We find that seller pairs contributions are higher than 2656-2656 contributions (35.27 and 29.03, respectively), but the difference fails to reach statistical significance $(p=0.1146)$. However, this non-significance can hardly be interpreted in favor of a positive affect of high earnings of contributions because contributions of 346-346 matchings are with 33.31 higher than contributions of 2656-2656 matchings and closer to those of seller pairs. Thus, there is no evidence that higher pre-SDG earnings are the cause for the higher contributions of seller pairs in market-strangers. We summarize our discussion in the next result.

Result 4. The differences in contributions in the social dilemma game observed in the market treatments cannot be attributed to the earnings differences generated in the market interactions.

\subsection{Subjective well-being and social value orientation}

In this section we first discuss if and how market experience affects subjective well-being followed by a discussion of the effect on social value orientation. Recall that we asked participants to respond to our subjective well-being question at two points during the experiment: in Part 1, at the very beginning of the experiment (initial subjective well-being), and in Part 5, after the market interaction (in the market treatments) and the first six rounds of the SDG had taken place (final subjective well-being). To control for inter-individual variability we focus on the change

in these measures from the first to second measurement point 24 Table 7 depicts descriptive

Table 7. Changes in subjective well-being and social value orientation

\begin{tabular}{lccccccc}
\hline \hline \multirow{2}{*}{ Treatment } & \multicolumn{2}{c}{ Change in subjective well-being } & & \multicolumn{3}{c}{ Change in social value orientation } \\
\cline { 2 - 4 } \cline { 6 - 7 } & Mean & St.Dev. & $\mathrm{N}$ & & Mean & St.Dev. & $\mathrm{N}$ \\
\hline Market-partners & -0.500 & 2.344 & 112 & & -2.447 & 17.619 & 112 \\
Market-strangers & -0.729 & 2.599 & 192 & & -6.031 & 19.259 & 192 \\
OSDG & -0.234 & 1.771 & 64 & & -4.538 & 13.682 & 64 \\
\hline
\end{tabular}

\footnotetext{
${ }^{24}$ Descriptive statistics of the initial and final values of these measures can be found in Appendix A.2. Table A.24
} 
Table 8. Regression: change in subjective well-being

\begin{tabular}{|c|c|c|c|}
\hline \multirow[b]{2}{*}{ Specification } & \multicolumn{3}{|c|}{ dep. var.: change in subjective well-being } \\
\hline & $(1)$ & $(2)$ & $(3)$ \\
\hline \multirow[t]{2}{*}{ Earnings in SDG 1} & $0.007^{* * *}$ & $0.005^{* *}$ & $0.005^{* * *}$ \\
\hline & $(0.002)$ & $(0.002)$ & $(0.247)$ \\
\hline \multirow[t]{2}{*}{ Market-partners } & -0.087 & & \\
\hline & $(0.259)$ & & \\
\hline \multirow[t]{2}{*}{ Market-strangers } & $-0.593^{* *}$ & & \\
\hline & $(0.256)$ & & \\
\hline \multirow[t]{2}{*}{ Buyer } & & $-1.130^{* * *}$ & \\
\hline & & $(0.285)$ & \\
\hline \multirow[t]{2}{*}{ Seller } & & $0.796^{* *}$ & \\
\hline & & $(0.243)$ & \\
\hline \multirow[t]{2}{*}{ Market-partners*Buyer } & & & $-0.614^{*}$ \\
\hline & & & $(0.333)$ \\
\hline \multirow[t]{2}{*}{ Market-partners*Seller } & & & $0.672^{* *}$ \\
\hline & & & $(0.334)$ \\
\hline \multirow[t]{2}{*}{ Market-strangers*Buyer } & & & $-1.424^{* * *}$ \\
\hline & & & $(0.335)$ \\
\hline \multirow[t]{2}{*}{ Market-strangers*Seller } & & & $0.859^{* * *}$ \\
\hline & & & $(0.248)$ \\
\hline \multirow[t]{2}{*}{ Constant (OSDG) } & $-3.236^{* * *}$ & $-2.237^{* *}$ & $-2.475^{* * *}$ \\
\hline & $(0.664)$ & $(0.714)$ & $(0.660)$ \\
\hline$R^{2}$ & 0.039 & 0.155 & 0.1691 \\
\hline \multirow[t]{2}{*}{$N$} & 368 & 368 & 368 \\
\hline & MP vs MS & Seller vs Buyer & all comp. sig. \\
\hline \multirow{2}{*}{$\begin{array}{l}F_{(1,57)} \\
p \text {-value }\end{array}$} & 3.68 & 43.96 & except \\
\hline & 0.0599 & 0.0000 & MS*Seller vs MP*Seller \\
\hline
\end{tabular}

statistics of these changes in the market treatments and OSDG. Focusing on subjective wellbeing first we see a general decline in this measure in all three treatments and this decline appears to be stronger in the market treatments than in OSDG.

To test if these differences are significant we have conducted regression analysis with the change in subjective well-being as the dependent variable and as independent variables the treatment participants have been in (dummy variable 'Market-partners' and 'Market-strangers' with OSDG being the reference category) and individual earnings in the first six periods of the SDG ('Earnings in SDG 1'). Specification (1) in Table 8 shows that there is a general statistically significant decline in subjective well-being (see Constant) that is significantly stronger for those who experienced the market-strangers treatment $(p=0.024)$. For market-partners the coefficient 
Table 9. Change in subjective well-being: comparison of market roles (cf. specification (3) in Table 8)

\begin{tabular}{|c|c|c|}
\hline \multirow{3}{*}{$\begin{array}{l}F_{(1,57)} \\
p \text {-value }\end{array}$} & MP*buyer $=$ MP $^{*}$ seller & MS*buyer=MS*seller \\
\hline & 8.36 & 44.58 \\
\hline & 0.0054 & 0.0000 \\
\hline \multirow{3}{*}{$\begin{array}{l}F_{(1,57)} \\
p \text {-value }\end{array}$} & MP*buyer=MS*buyer & $\mathrm{MP}^{*}$ seller $=\mathrm{MS}^{*}$ seller \\
\hline & 4.21 & 0.38 \\
\hline & 0.0448 & 0.5427 \\
\hline \multirow{3}{*}{$\begin{array}{l}F_{(1,57)} \\
p \text {-value }\end{array}$} & $\mathrm{MP}^{*}$ buyer $=\mathrm{MS}^{*}$ seller & $\mathrm{MP}^{*}$ seller $=\mathrm{MS}^{*}$ buyer \\
\hline & 21.37 & 28.31 \\
\hline & 0.0000 & 0.0000 \\
\hline
\end{tabular}

is also negative but statistically not significant $(p=0.739)$. Between the two market treatments the difference in the decrease in subjective well-being is statistically marginally significant at $p=0.060$. Not surprisingly earnings in the SDG have a highly significant positive impact on the change in subjective well-being $(p \leq 0.001)$.

Specification (2) of Table 8 distinguishes between buyers and sellers (and for the moment ignores which market they have been in). The results for this regression show that, relative to OSDG participants, sellers report a significant increase in their subject well-being $(p=0.002)$, while buyers experience a significant decrease $(p \leq 0.001)$. The difference between buyers and sellers is highly significant $(p \leq 0.001)$. Also in this specification earnings in the SDG have a positive impact on the change in subjective well-being $(p \leq 0.007)$.

Finally, specification (3) shows that the buyers experience a (marginal) significant negative effect in both market-partners $(p=0.066)$ and market-strangers $(p<0.001)$, whereas it is significantly positive for sellers irrespective of the type of experienced market (market-partners: $p=0.066$, market-strangers: $p<0.001$ ). All differences between buyers and sellers are statistically significant $(p \leq 0.005$; see Table 9).

We summarize the results pertaining to subjective well-being as follows:

Result 5. Subjective well-being is generally decreasing over time. In both market environments, it decreases most strongly for market-losers (buyers) and least strongly for market-winners (sellers).

In Table 7 the right hand side reports descriptive statistics of participants' change in social value orientation. Consistent with the literature (Sonnemans et al., 2006; Brandts et al., 2009), social value orientation exhibits a general decline over time. Interestingly, relative to the benchmark OSDG the decline appears stronger for participants in market-strangers and weaker 
Table 10. Regression: change in social value orientation

\begin{tabular}{|c|c|c|c|}
\hline \multirow[b]{2}{*}{ Specification } & \multicolumn{3}{|c|}{ dep. var.: change in social value orientation } \\
\hline & $(1)$ & $(2)$ & $(3)$ \\
\hline \multirow[t]{2}{*}{ Earnings in SDG 1} & 0.039 & 0.027 & 0.034 \\
\hline & $(0.023)$ & $(0.020)$ & $(0.023)$ \\
\hline \multirow[t]{2}{*}{ Market-partners } & 3.101 & & \\
\hline & $(2.510)$ & & \\
\hline \multirow[t]{2}{*}{ Market-strangers } & -2.047 & & \\
\hline & $(2.180)$ & & \\
\hline \multirow[t]{2}{*}{ Buyer } & & -1.742 & \\
\hline & & $(1.887)$ & \\
\hline \multirow[t]{2}{*}{ Seller } & & 2.483 & \\
\hline & & $(2.386)$ & \\
\hline \multirow[t]{2}{*}{ Market-partners*Buyer } & & & 2.740 \\
\hline & & & $(2.361)$ \\
\hline \multirow[t]{2}{*}{ Market-partners*Seller } & & & 3.386 \\
\hline & & & $(4.088)$ \\
\hline \multirow[t]{2}{*}{ Market-strangers*Buyer } & & & $-4.276^{* *}$ \\
\hline & & & $(2.088)$ \\
\hline \multirow[t]{2}{*}{ Market-strangers*Seller } & & & 1.842 \\
\hline & & & $(2.714)$ \\
\hline \multirow[t]{2}{*}{ Constant (OSDG) } & $-21.489^{* *}$ & $-16.165^{*}$ & $-19.491^{*}$ \\
\hline & $(10.217)$ & $(8.572)$ & $(10.015)$ \\
\hline$R^{2}$ & 0.027 & 0.023 & 0.041 \\
\hline \multirow[t]{2}{*}{$N$} & 368 & 368 & 368 \\
\hline & MP vs MS & Seller vs Buyer & all comp. sig. \\
\hline \multirow{2}{*}{$\begin{array}{l}F_{(1,57)} \\
p \text {-value }\end{array}$} & 3.18 & 5.57 & except \\
\hline & 0.0800 & 0.0217 & MS*Seller vs MP*Seller \\
\hline
\end{tabular}

for those in market-partners. To test for statistical significance we have run regressions similar to those for subjective well-being. Table 10 reports the results. The regressions confirm the general decrease in social value orientation but show little significant differences between the OSDG benchmark and, respectively, the market treatments and trader roles. The exception are buyers in the market-strangers treatment who decrease their social value orientation significantly more than participants in OSDG (specification $(3), p=0.045)$. However, there are interesting differences between buyers and sellers. When disregarding the market treatments we see that buyers decrease their social value orientation significantly more than sellers (specification (2), $p=0.0217)$. Using the results from specification (3), Table 11 shows that this is mainly due to the difference in market-strangers $(p<0.001)$. Buyers decrease their social value orienta- 
Table 11. Change in social value orientation: comparison of market roles (cf. specification (3) in Table 10)

\begin{tabular}{|c|c|c|}
\hline \multirow{3}{*}{$\begin{array}{l}F_{(1,57)} \\
p \text {-value }\end{array}$} & $\mathrm{MP}^{*}$ buyer $=\mathrm{MP}^{*}$ seller & MS*buyer $=$ MS ${ }^{*}$ seller \\
\hline & 0.03 & 12.51 \\
\hline & 0.8662 & 0.0008 \\
\hline \multirow{3}{*}{$\begin{array}{l}F_{(1,57)} \\
p \text {-value }\end{array}$} & $\mathrm{MP}^{*}$ buyer $=$ MS*buyer & $\mathrm{MP}^{*}$ seller $=\mathrm{MS}^{*}$ seller \\
\hline & 7.02 & 0.11 \\
\hline & 0.0104 & 0.7431 \\
\hline \multirow{3}{*}{$\begin{array}{l}F_{(1,57)} \\
p \text {-value }\end{array}$} & $\mathrm{MP}^{*}$ buyer $=\mathrm{MS}^{*}$ seller & $\mathrm{MP}^{*}$ seller $=\mathrm{MS}^{*}$ buyer \\
\hline & 0.08 & 3.23 \\
\hline & 0.7795 & 0.0776 \\
\hline
\end{tabular}

tion more than sellers also in market-partners, but the decrease is statistically not significant $(p=0.8662)$.

We summarize the results regarding social value orientation as follows.

Result 6. Social value orientation is generally decreasing over time. Overall, market-losers (buyers) decrease their social value orientation more than market-winners (sellers). This effect is strongest for market-losers who interacted in market-strangers before.

\section{$7 \quad$ Summary and conclusions}

In this paper we explored whether competing in a market under different conditions affects the efficiency of interaction in a subsequent social dilemma game. We find that efficiency in the social dilemma is lower for people who competed with each other in the market on the same side than for people who interacted in different markets or for people without market experience. This holds both for market-losers and market-winners. It appears that having been competitors on the same market hampers later cooperation between people. In this sense competitive market experience is harmful for efficient cooperation. Having competed on the same side in the same market is harmful for subsequent cooperation, even if this competition has taken place on the favorable side of the market. Interestingly, pairs formed by one market-loser and one market-winner from the same market do not experience this drop in efficiency. These results are consistent with the notion that direct competition destroys affective social ties or may even lead to negative affective ties as discussed in van Dijk and van Winden (1997) and van Winden (2012).

We also find a positive effect of competition on the efficiency of cooperation, but only when market-winners from two separate markets have been paired. This indicates that having had a 
positive experience on a market can lead to more efficient outcomes but only when the competition was not with people one also needs to solve the social dilemma with. This finding resonates with the observations of Camerer and Fehr (2004) in small-scale societies. They find that exposure to market interactions with strangers can have a positive effect on social behavior towards partners from the own society.

Next to the effects on cooperative behavior, we find that market participation also affects subjective well-being and social value orientation. Our results show that for market-losers subjective well-being and social value orientation both worsen compared to market-winners. In addition, the social value orientation of market-strangers worsens with respect to that of market-partners. It is not easy to interpret this result. A possible interpretation is that the higher social distance in the market-strangers setting has a more negative impact on social value orientation, although it may be a stretch to use the notion of social distance in the context of a lab experiment.

Overall, our findings on the effects of market experience on the efficiency of cooperation are in line with the view of Bowles (1998) presented in the introduction but also refine it. Market experience does affect cooperation but it is neither market experience per se nor being on the long or short side on the market per se that is adverse to efficient cooperation. It is the fact of having competed with each other on the same market and on the same side that makes subsequent cooperation difficult, irrespective of having been a market-loser or market-winner. Moreover, market experience can have a positive effect on subsequent cooperation for market-winners but only when the social dilemma needs to be solved with somebody one has not interacted with before on the same market.

Interestingly, in our experiment the market experience effects on cooperation appear to be decoupled from the effects on subjective well-being and social value orientation. In both market treatments buyers score worse on these individual measures than sellers and participants in market-strangers score worse than those having experienced market-partners. This suggests that worse subjective well-being not necessarily impedes the ability to cooperate efficiently and that worse social value orientation towards a generalized other does not necessarily correlate with the inclination to cooperate with a specific other. However, we also need to note a caveat regarding these latter results. Both individual characteristics are not measured immediately after the market experience because our foremost focus was on the effect of market experience on cooperation behavior. The measurements are therefore confounded with experience in the social dilemma game and future research could try to explore causal effects of market experience on subjective well-being and social value orientation. Further, the subjective well-being measure 
relies on self-assessment and is therefore noisy or even biased. Future research may investigate subjective well-being using more objective measures.

We have motivated our hypotheses using the framework of Bowles and Polania-Reyes (2012), who argue that preferences are state-dependent in the sense that ". . actions are motivated by a repertoire of heterogeneous preferences the salience of which depends on the nature of the decision situation." (p.372) The nature of the decision situation can also be affected by social experiences and different experiences can trigger different states. Thus, our results can be understood in terms of state-dependent preferences. We provide evidence that market experience can affect other social behavior but this evidence does not allow us to pin down precisely what mechanisms are behind these effects. The investigation of these mechanisms could be an exciting future research avenue. 


\section{References}

Andreoni, J. (1988). Why free ride? Strategies and learning in public goods experiments. Journal of Public Economics, 37:291304.

Bartling, B., Weber, R. A., and Yao, L. (2015). Do markets erode social responsibility? Quarterly Journal of Economics, 130(1):219-266.

Bauernschuster, S., Falck, O., and Große, N. (2013). When trustors compete for the favour of a trustee-a laboratory experiment. Journal of Economic Psychology, 34:133-147.

Benjamini, Y. and Hochberg, Y. (1995). Controlling the false discovery rate: A practical and powerful approach to multiple testing. Journal of the Royal Statistical Society, 57(1):289-300.

Black, S. E., Devereux, P. J., and Salvanes, K. G. (2005). Why the apple doesn't fall far: Understanding intergenerational transmission of human capital. American Economic Review, 95(1):437-449.

Bolton, G. and Ockenfels, A. (2000). ERC: A theory of equity, reciprocity, and competition. American Economic Review, 90(1):166-193.

Bowles, S. (1998). Endogenous preferences: the cultural consequences of markets and other economic institutions. Journal of Economic Literature.

Bowles, S. and Polania-Reyes, S. (2012). Economic incentives and social preferences: Substitutes or complements? Journal of Economic Literature, 50(2):368-425.

Brandts, J., Riedl, A., and Winden, F. v. (2009). Competitive rivalry, social disposition, and subjective well-being: An experiment. Journal of Public Economics, 93(11/12):1158-1167.

Buser, T. and Dreber, A. (2013). The flipside of comparative payment schemes. Tinbergen Institute Discussion Paper, TI2013-190/I.

Camerer, C. F. and Fehr, E. (2004). Measuring social norms and preferences using experimental games: A guide for social scientists. In Henrich, J., Boyd, R., Bowles, S., Camerer, C., Fehr, E., and Gintis, H., editors, Foundations of Human Sociality: Economic Experiments and Ethnographic Evidence from Fifteen Small-Scale Societies, chapter 3, pages 55-95. Oxford University Press, Oxford, UK.

Carpenter, J. and Seki, E. (2006). Competitive work environments and social preferences: Field experimental evidence from a japanese fishing community. Contributions to Economic Analysis G Policy, BE Press, 5(2). Article 2.

Charness, G. and Rabin, M. (2002). Understanding social preferences with simple tests. Quarterly Journal of Economics, 117:817-869. 
Chaudhuri, A. (2011). Sustaining cooperation in laboratory public goods experiments: a selective survey of the literature. Experimental Economics, 14:47-83.

Chen, D. L. (2011). Markets and morality: How does competition affect moral judgement? Working Paper.

Cowell, F. A. and Van Kerm, P. (2015). Wealth inequality: A survey. Journal of Economic Surveys, 29(4):671710.

Croson, R. T. A. (1996). Partners and strangers revisited. Economics Letters, 53:2532.

Davis, D. D. and Holt, C. A. (1993). Experimental economics, chapter 3. Double-auction markets. Princeton University Press.

Engels, F. (1987/1845). The condition of the working class in England. Penguin UK. First published 1845, Germany.

Falk, A. and Heckman, J. J. (2009). Lab experiments are a major source of knowledge in the social sciences. Science, 326:535-538.

Falk, A. and Szech, N. (2013). Morals and markets. Science, 340:707-711.

Fehr, E. and Hoff, K. (2011). Tastes, castes and culture: The influence of society on preferences. Economic Journal, 112(556):396-412.

Fehr, E. and Schmidt, K. (1999). A theory of fairness, competition, and cooperation. Quarterly Journal of Economics, 114:817-868.

Fischbacher, U. (2007). z-tree: Zurich toolbox for ready-made economic experiments. Experimental Economics, 10(2):171-178.

Fourcade, M. and Healy, K. (2007). Moral views of market society. Annual Review of Sociology, 33.

Henrich, J., Boyd, R., Bowles, S., Camerer, C., Fehr, E., Gintis, H., and McElreath, R. (2001). In search of homo economicus: Behavioral experiments in 15 small-scale societies. American Economic Review, 91(2):72-78.

Herz, H. and Taubinsky, D. (2013). Market experience is a reference point in judgments of fairness. Working Paper. Available at SSRN 2297773.

Holt, C. A., Langan, L., and Villamil, A. (1986). Market power in oral double auctions. Economic Inquiry, 24:107-123.

Huck, S., Lünser, G. K., and Tyran, J.-R. (2012). Competition fosters trust. Games and Economic Behavior, 76(1):195-209.

Kagel, J. H. and Roth, A. E., editors (2012). The Handbook of Experimental Economics, volume 2. Princeton University Press, Princeton, New Jersey. forthcoming. 
Lang, P. J. (1980). Behavioral treatment and bio-behavioral assessments: Computer applications. In Sidowsky, J., Johnson, J., and Williams, T., editors, Technology in Mental Health Care Delivery Systems. NJ Ablex, Norwood.

Lelkes, O. (2010). Social participation and social isolation. In Atkinson, A. B. and Marlier, E., editors, Income and living conditions in Europe, Eurostat Statistical Books, chapter 10, pages 217-240. Eurostat Publications Office of the European Union, Luxembourg.

Liebrand, W. (1984). The effect of social motives, communication and group sizes on behaviour in an N-person multi-stage mixed motive game. European Journal of Social Psychology, $14: 239264$.

Marquis, M. H., Trehan, B., and Tantivong, W. (2014). The wage premium puzzle and the quality of human capital. International Review of Economics and Finance, 33:100110.

Mas-Colell, A., Whinston, M. D., and Green, J. R. (1995). Microeconomic Theory. Oxford University Press, Oxford, UK.

Montesquieu, C. B. d. S. (1748). The Spirit of Laws. Crowder, Wark, and Payne, 1777. Originally published anonymously. Trans. Thomas Nugent (1750).

Murphy, R. O., Ackermann, K. A., and Handgraaf, M. J. J. (2011). Measuring social value orientation. Judgment and Decision Makin, 6(8):771-781.

Noussair, C. and Tucker, S. (2013). A Collection of Surveys on Market Experiments. Surveys of Recent Research in Economics. Wiley.

Restuccia, D. and Urrutia, C. (2004). Intergenerational persistence of earnings: The role of early and college education. American Economic Review, 94(5):1354-1378.

Rotter, J. B. (1966). Generalized expectancies for internal versus external control of reinforcement. Psychological monographs: General and applied, 80(1):1.

Sandel, M. J. (2012). What Money Can't Buy: The Moral Limits of Markets. Farrar, Straus and Giroux, New York.

Sandel, M. J. (2013). Market reasoning as moral reasoning: why economists should re-engage with political philosophy. The Journal of Economic Perspectives, pages 121-140.

Sidanius, J. and Pratto, F. (2004). Social dominance theory: A new synthesis. In Jost, J. T. and Sidanius, J., editors, Political psychology: Key readings. Key readings in social psychology, pages 315-332. Psychology Press, New York, NY.

Simon, H. A. (1956). Rational choice and the structure of the environment. Psychological Review, 63(2):129138.

Smith, V. (1962). An experimental study of competitive market behavior. Journal of Political 
Economy, 70:111-137.

Smith, V. (1976). Experimental economics: induced value theory. American Economic Review, $66: 274-279$.

Smith, V. (1998). The two faces of adam smith. Southern Economic Journal, 65(1):1-19.

Sonnemans, J. (1991). Structure and Determinants of Emotional Intensity. PhD thesis, University of Amsterdam.

Sonnemans, J., van Dijk, F., and van Winden, F. (2006). On the dynamics of social ties structures in groups. Journal of Economic Psychology, 27:187204.

Standing, G. (2011). The Precariat; The Dangerous New Class. Bloomsbury Academic.

van Dijk, F. and van Winden, F. (1997). Dynamics of social ties and local public good provision. Journal of Public Economics, 64(3):323 - 341.

Van Lange, P. A. M. (1999). The pursuit of joint outcomes and equality in outcomes: An integrative model of social value orientation. Journal of Personality and Social Psychology, $77(2): 337-349$.

van Winden, F. (2012). Affective social ties - Missing link in governance theory. Rationality, Morals and Markets, 3(108-122). 


\section{$* * *$ Not for publication. $* * *$}

\section{A Additional Statistical Results}

\section{A.1 Contributions in the Social Dilemma Game}

\section{A.1.1 Descriptive Statistics and Non-Parametric Tests}

Tests for differences in contributions in the social dilemma game across treatments (aggregated over trader matchings). (cf. Table 2)

Table A.1. Contributions in social dilemma game (all trader matchings, all periods)

\begin{tabular}{lccc}
\hline \hline Treatment & mean & st. dev. & $\mathrm{N}^{1}$ \\
\hline Market-partners & 22.456 & 7.148 & 14 \\
Market-strangers & 30.754 & 3.120 & 12 \\
OSDG & 29.375 & 15.037 & 32 \\
\hline Kruskal-Wallis test $^{2}$ & $p=0.0673$ \\
Pair-wise comparisons: & & \\
MP vs MS & $p=0.0353$ \\
MP vs OSDG & $p=0.0656$ \\
MS vs OSDG & $p=0.1550$ \\
\hline Note: ${ }^{1}$ all statistics are based on striclty indpendent ob- \\
servations; ${ }^{2}$ Dunn tests with false-discovery rate adjust- \\
ment (Beniamini and Hochberg, \\
for Market-partners (-strangers)
\end{tabular}

Table A.2. Contributions in social dilemma game (all trader matchings, periods 1-6)

\begin{tabular}{lccc}
\hline \hline Treatment & mean & st. dev. & $\mathrm{N}^{1}$ \\
\hline Market-partners & 23.025 & 7.556 & 14 \\
Market-strangers & 31.418 & 3.154 & 12 \\
OSDG & 28.451 & 14.744 & 32 \\
\hline Kruskal-Wallis test $^{2}$ & $p=0.0975$ \\
Pair-wise comparisons: & & \\
MP vs MS & $p=0.0466$ \\
MP vs OSDG & $p=0.1471$ \\
MS vs OSDG & $p=0.0999$ \\
\hline Note: ${ }^{1}$ all statistics are based on striclty indpendent ob- \\
servations; ${ }^{2}$ Dunn tests with false-discovery rate adjust- \\
ment: MP (MS) stands for Market-partners (-strangers) \\
(Benjamini and Hochberg, 1995)
\end{tabular}


Table A.3. Contributions in social dilemma game (all trader matchings, periods 7-18)

\begin{tabular}{lccc}
\hline \hline Treatment & mean & st. dev. & $\mathrm{N}^{1}$ \\
\hline Market-partners & 22.172 & 7.502 & 14 \\
Market-strangers & 30.422 & 3.612 & 12 \\
OSDG & 29.837 & 16.035 & 32 \\
\hline Kruskal-Wallis test & $p=0.0964$ & \\
Pair-wise comparisons: $^{2}$ & & \\
MP vs MS & $p=0.0551$ & \\
MP vs OSDG & $p=0.0746$ & \\
MS vs OSDG & \multicolumn{2}{c}{$p=0.1928$} \\
\hline
\end{tabular}

Note: ${ }^{1}$ all statistics are based on striclty indpendent observations; ${ }^{2}$ Dunn tests with false-discovery rate adjustment: MP (MS) stands for Market-partners (-strangers) (Beniamini and Hochberg, 1995) 
Tests for differences in contributions in the social dilemma game across treatments by trader trader matchings. (cf. Tables 3 and 4)

Table A.4. Contributions in social dilemma game by trader matchings (all periods)

\begin{tabular}{|c|c|c|c|c|c|c|c|}
\hline \multirow{2}{*}{$\begin{array}{l}\text { Trader matching* } \\
\text { Treatment }\end{array}$} & \multicolumn{2}{|c|}{ buyer pairs } & \multicolumn{2}{|c|}{ seller pairs } & \multicolumn{2}{|c|}{ mixed pairs } & \multirow[b]{2}{*}{$\mathrm{N}^{1}$} \\
\hline & mean & st. dev. & mean & st. dev. & mean & st. dev. & \\
\hline Market-partners & 19.697 & 10.348 & 21.056 & 12.832 & 29.375 & 15.190 & 14 \\
\hline Market-strangers & 28.405 & 6.003 & 35.274 & 7.028 & 30.932 & 7.864 & 12 \\
\hline OSDG & 29.375 & 15.037 & 29.375 & 15.037 & 29.375 & 15.037 & 32 \\
\hline $\begin{array}{l}\text { Kruskal-Wallis test } \\
\text { Pair-wise comparisons: }\end{array}$ & \multicolumn{2}{|c|}{$p=0.0993$} & \multicolumn{2}{|c|}{$p=0.0357$} & \multicolumn{2}{|c|}{$p=0.9134$} & \\
\hline MP vs MS & \multicolumn{2}{|c|}{$p=0.0583$} & \multicolumn{2}{|c|}{$p=0.0161$} & \multicolumn{2}{|c|}{$p=0.5290$} & \\
\hline MP vs OSDG & \multicolumn{2}{|c|}{$p=0.0665$} & \multicolumn{2}{|c|}{$p=0.0578$} & \multicolumn{2}{|c|}{$p=0.4788$} & \\
\hline MS vs OSDG & \multicolumn{2}{|c|}{$p=0.4417$} & \multicolumn{2}{|c|}{$p=0.0982$} & \multicolumn{2}{|c|}{$p=1.0000$} & \\
\hline
\end{tabular}

Note: ${ }^{*}$ in OSDG trader matching refers to matched pair in SDG; ${ }^{1}$ all statistics are based on striclty indpendent observations; ${ }^{2}$ Dunn tests with false-discovery rate adjustment (Beniamini and Hochberg, 1995); MP (MS) stands for Market-partners (-strangers)

Table A.5. Contributions in social dilemma game by trader matchings (periods 1-6)

\begin{tabular}{|c|c|c|c|c|c|c|c|}
\hline \multirow{2}{*}{$\begin{array}{l}\text { Trader matching }{ }^{*} \\
\text { Treatment }\end{array}$} & \multicolumn{2}{|c|}{ buyer pairs } & \multicolumn{2}{|c|}{ seller pairs } & \multicolumn{2}{|c|}{ mixed pairs } & \multirow[b]{2}{*}{$\mathrm{N}^{1}$} \\
\hline & mean & st. dev. & mean & st. dev. & mean & st. dev. & \\
\hline Market-partners & 21.729 & 8.751 & 21.768 & 12.413 & 26.875 & 15.507 & 14 \\
\hline Market-strangers & 29.236 & 5.854 & 35.486 & 7.428 & 31.715 & 7.368 & 12 \\
\hline OSDG & 28.451 & 14.744 & 28.451 & 14.744 & 28.451 & 14.744 & 32 \\
\hline $\begin{array}{l}\text { Kruskal-Wallis test } \\
\text { Pair-wise comparisons: }\end{array}$ & \multicolumn{2}{|c|}{$p=0.1711$} & \multicolumn{2}{|c|}{$p=0.0284$} & \multicolumn{2}{|c|}{$p=0.7630$} & \\
\hline MP vs MS & \multicolumn{2}{|c|}{$p=0.1101$} & \multicolumn{2}{|c|}{$p=0.0121$} & \multicolumn{2}{|c|}{$p=0.6961$} & \\
\hline MP vs OSDG & \multicolumn{2}{|c|}{$p=0.1032$} & \multicolumn{2}{|c|}{$p=0.0574$} & \multirow{2}{*}{\multicolumn{2}{|c|}{$\begin{array}{l}p=0.3606 \\
p=0.4559\end{array}$}} & \\
\hline MS vs OSDG & \multicolumn{2}{|c|}{$p=0.2498$} & \multicolumn{2}{|c|}{$p=0.0805$} & & & \\
\hline
\end{tabular}

Note: ${ }^{*}$ in OSDG trader matching refers to matched pair in SDG; ${ }^{1}$ all statistics are based on striclty indpendent observations; ${ }^{2}$ Dunn tests with false-discovery rate adjustment (Beniamini and Hochberg, 1995); MP (MS) stands for Market-partners (-strangers) 
Table A.6. Contributions in social dilemma game by trader matchings (periods 7-18)

\begin{tabular}{|c|c|c|c|c|c|c|c|}
\hline \multirow{2}{*}{$\begin{array}{l}\text { Trader matching }{ }^{*} \\
\text { Treatment }\end{array}$} & \multicolumn{2}{|c|}{ buyer pairs } & \multicolumn{2}{|c|}{ seller pairs } & \multicolumn{2}{|c|}{ mixed pairs } & \multirow[b]{2}{*}{$\mathrm{N}^{1}$} \\
\hline & mean & st. dev. & mean & st. dev. & mean & st. dev. & \\
\hline Market-partners & 18.682 & 11.849 & 20.699 & 14.385 & 30.625 & 16.213 & 14 \\
\hline Market-strangers & 27.990 & 6.707 & 35.168 & 7.323 & 30.540 & 9.051 & 12 \\
\hline OSDG & 29.837 & 16.035 & 29.837 & 16.035 & 29.837 & 16.035 & 32 \\
\hline $\begin{array}{l}\text { Kruskal-Wallis test } \\
\text { Pair-wise comparisons: }\end{array}$ & \multicolumn{2}{|c|}{$p=0.0392$} & \multicolumn{2}{|c|}{$p=0.0477$} & \multicolumn{2}{|c|}{$p=0.9835$} & \\
\hline MP vs MS & \multicolumn{2}{|c|}{$p=0.0345$} & \multicolumn{2}{|c|}{$p=0.0264$} & \multicolumn{2}{|c|}{$p=0.6708$} & \\
\hline MP vs OSDG & \multicolumn{2}{|c|}{$p=0.0225$} & \multicolumn{2}{|c|}{$p=0.0432$} & \multicolumn{2}{|c|}{$p=1.0000$} & \\
\hline MS vs OSDG & \multicolumn{2}{|c|}{$p=0.4935$} & \multicolumn{2}{|c|}{$p=0.1683$} & \multicolumn{2}{|c|}{$p=0.4942$} & \\
\hline
\end{tabular}

Note: ${ }^{*}$ in OSDG trader matching refers to matched pair in SDG; ${ }^{1}$ all statistics are based on striclty indpendent observations; ${ }^{2}$ Dunn tests with false-discovery rate adjustment (Beniamini and Hochberg, 1995); MP (MS) stands for Market-partners (-strangers) 
Tests for differences in contributions in the social dilemma game by trader trader matchings with treatments. (cf. Tables [5, A.16, A.19 and A.20)

Table A.7. Tests for differences in contributions in social dilemma game by trader matchings within treatments (all periods)

\begin{tabular}{lcc}
\hline \hline Treatments & Market-partners & Market-strangers \\
\hline Kruskal-Wallis test & $p=0.1241$ & $p=0.0872$ \\
Pair-wise comparisons: & & \\
Buyer pairs vs seller pairs & $p=0.4027$ & $p=0.0473$ \\
Buyer pairs vs mixed pairs & $p=0.0903$ & $p=0.2613$ \\
Seller pairs vs mixed pairs & $p=0.0769$ & $p=0.0980$ \\
\hline Note: $^{1}$ all statistics are based on striclty indpendent observations: ${ }^{2}$ Dunn tests \\
with false-discovery rate adjustment (Benjamini and Hochberg, $^{\text {1995) }}$ (B)
\end{tabular}

Table A.8. Tests for differences in contributions in social dilemma game by trader matchings within treatments (periods 1-6)

\begin{tabular}{lcc}
\hline \hline Treatments & Market-partners & Market-strangers \\
\hline Kruskal-Wallis test & $p=0.6404$ & $p=0.1089$ \\
Pair-wise comparisons: $^{2}$ & & \\
Buyer pairs vs seller pairs & $p=0.4449$ & $p=0.0572$ \\
Buyer pairs vs mixed pairs & $p=0.3447$ & $p=0.2367$ \\
Seller pairs vs mixed pairs & $p=0.5698$ & $p=0.1313$ \\
\hline
\end{tabular}

Note: ${ }^{1}$ all statistics are based on striclty indpendent observations: ${ }^{2}$ Dunn tests with false-discovery rate adjustment (Benjamini and Hochberg, 1995)

Table A.9. Tests for differences in contributions in social dilemma game by trader matchings within treatments (periods 7-18)

\begin{tabular}{lcc}
\hline \hline Treatments & Market-partners & Market-strangers \\
\hline Kruskal-Wallis test & $p=0.0956$ & $p=0.0941$ \\
Pair-wise comparisons: ${ }^{2}$ & & \\
Buyer pairs vs seller pairs & $p=0.3878$ & $p=0.0533$ \\
Buyer pairs vs mixed pairs & $p=0.0678$ & $p=0.2838$ \\
Seller pairs vs mixed pairs & $p=0.0644$ & $p=0.0944$ \\
\hline
\end{tabular}

Note: ${ }^{1}$ all statistics are based on striclty indpendent observations: ${ }^{2}$ Dunn tests with false-discovery rate adjustment (Beniamini and Hochberg, 1995) 


\section{A.1.2 Additional Regression Analysis}

Table A.10. Tests for differences in contributions in the social dilemma game across treatments (aggregated over trader matchings) - OLS with period dummies (cf. Table 2)

\begin{tabular}{|c|c|c|c|}
\hline \multirow{3}{*}{ Specification } & \multicolumn{3}{|c|}{ dep. var.: contribution to public good } \\
\hline & $(1)$ & $(2)$ & $(3)$ \\
\hline & all periods & periods $1-6$ & periods $7-18$ \\
\hline \multirow[t]{2}{*}{ Market-partners } & $-6.919^{* *}$ & -5.425 & $-7.665^{* *}$ \\
\hline & $(3.232)$ & $(3.253)$ & $(3.428)$ \\
\hline \multirow[t]{2}{*}{ Market-strangers } & 1.379 & 2.968 & 0.585 \\
\hline & $(2.783)$ & $(2.737)$ & $(2.993)$ \\
\hline \multirow[t]{2}{*}{ Constant (OSDG) } & $34.321^{* * *}$ & $33.037^{* * *}$ & $31.900^{* * *}$ \\
\hline & $(2.521)$ & $(2.472)$ & $(2.829)$ \\
\hline Period dummies & yes & yes & yes \\
\hline$R^{2}$ & 0.087 & 0.1351 & 0.066 \\
\hline \multirow[t]{2}{*}{$N$} & 6624 & 2208 & 4416 \\
\hline & \multicolumn{3}{|c|}{ MP vs MS } \\
\hline \multirow{2}{*}{$\begin{array}{l}F_{(1,57)} \\
p \text {-value }\end{array}$} & 16.33 & 15.18 & 14.10 \\
\hline & 0.0002 & 0.0003 & 0.0004 \\
\hline
\end{tabular}


Table A.11. Tests for differences in contributions in the social dilemma game across treatments (aggregated over trader matchings) - Tobit regressions (cf. Table 2)

\begin{tabular}{|c|c|c|c|}
\hline \multirow{3}{*}{ Specification } & \multicolumn{3}{|c|}{ dep. var.: contribution to public good } \\
\hline & $(1)$ & $(2)$ & $(3)$ \\
\hline & all periods & periods $1-6$ & periods $7-18$ \\
\hline \multirow[t]{2}{*}{ Market-partners } & $-13.128^{* *}$ & -8.382 & $-15.940^{* *}$ \\
\hline & $(5.936)$ & $(5.360)$ & $(6.670)$ \\
\hline \multirow[t]{2}{*}{ Market-strangers } & 0.723 & 4.208 & -1.313 \\
\hline & $(5.248)$ & $(4.610)$ & $(5.984)$ \\
\hline \multirow[t]{2}{*}{ Constant (OSDG) } & $35.230^{* * *}$ & $31.964^{* * *}$ & $37.162^{* * *}$ \\
\hline & $(5.095)$ & $(4.413)$ & $(5.785)$ \\
\hline$F(2, N-2)$ & 7.71 & 6.81 & 7.05 \\
\hline $\operatorname{Prob}>F$ & 0.0005 & 0.0011 & 0.0009 \\
\hline \multirow[t]{2}{*}{$N$} & 6624 & 2208 & 4416 \\
\hline & \multicolumn{3}{|c|}{ MP vs MS } \\
\hline \multirow{2}{*}{$\begin{array}{l}F_{(1,57)} \\
p \text {-value }\end{array}$} & 15.27 & 13.45 & 13.48 \\
\hline & 0.0001 & 0.0003 & 0.0002 \\
\hline \multicolumn{4}{|c|}{$\begin{array}{l}\text { Note: }{ }^{* * *},\left({ }^{* *}\right),\left[{ }^{*}\right] \text { indicated significance on } 1,5 \text {, and } 10 \text { percent level } \\
\text { respectively. Tobit regressions with lower (upper) bound on contributions } \\
\text { at } 0(50) \text { and standard errors corrected for dependence of observations for }\end{array}$} \\
\hline
\end{tabular}

Table A.12. Tests for differences in contributions in the social dilemma game across treatments by trader matchings (all periods) - OLS with period dummies (cf. Table 3)

\begin{tabular}{|c|c|c|c|}
\hline \multirow{3}{*}{ Specification } & \multicolumn{3}{|c|}{ / dep. var.: contribution to public good } \\
\hline & $(1)$ & $(2)$ & $(3)$ \\
\hline & buyer pairs & seller pairs & mixed pairs \\
\hline \multirow[t]{2}{*}{ Market-partners } & $-9.678^{* *}$ & $-8.319^{*}$ & -0.000 \\
\hline & $(3.777)$ & $(4.268)$ & $(4.765)$ \\
\hline \multirow[t]{2}{*}{ Market-strangers } & -0.970 & $5.899^{*}$ & 1.557 \\
\hline & $(3.133)$ & $(3.299)$ & $(3.444)$ \\
\hline \multirow[t]{2}{*}{ Constant (OSDG) } & $34.917^{* * *}$ & $32.356^{* * *}$ & $32.859^{* * *}$ \\
\hline & $(2.478)$ & $(2.335)$ & $(2.269)$ \\
\hline Period dummies & yes & yes & yes \\
\hline$R^{2}$ & 0.100 & 0.114 & 0.046 \\
\hline \multirow[t]{2}{*}{$N$} & 3888 & 2520 & 2520 \\
\hline & & MP vs M & \\
\hline \multirow{2}{*}{$\begin{array}{l}F_{(1,57)} \\
p \text {-value }\end{array}$} & 7.52 & 13.42 & 0.12 \\
\hline & 0.0081 & 0.0005 & 0.7325 \\
\hline
\end{tabular}

Note: ${ }^{* * *},\left({ }^{* *}\right),\left[{ }^{*}\right]$ indicated significance on 1,5 , and 10 percent level, respectively. OLS regressions with standard errors corrected for dependence of observations for 58 clusters. 
Table A.13. Tests for differences in contributions in the social dilemma game across treatments by trader matchings (all periods) - Tobit regressions (cf. Table 3 )

\begin{tabular}{|c|c|c|c|}
\hline \multirow{3}{*}{ Specification } & \multicolumn{3}{|c|}{ dep. var.: contribution to public good } \\
\hline & $(1)$ & $(2)$ & $(3)$ \\
\hline & buyer pairs & seller pairs & mixed pairs \\
\hline \multirow[t]{2}{*}{ Market-partners } & $-17.310^{* * *}$ & $-15.408^{*}$ & -0.317 \\
\hline & $(6.447)$ & $(7.900)$ & $(9.677)$ \\
\hline \multirow[t]{2}{*}{ Market-strangers } & -3.740 & 8.510 & 2.840 \\
\hline & $(5.708)$ & $(6.075)$ & $(7.104)$ \\
\hline \multirow[t]{2}{*}{ Constant (OSDG) } & $34.724^{* * *}$ & $34.933^{* * *}$ & $36.067^{* * *}$ \\
\hline & $(4.963)$ & $(5.180)$ & $(5.691)$ \\
\hline$F(2, N-2)$ & 4.24 & 5.79 & 0.10 \\
\hline $\operatorname{Prob}>F$ & 0.0144 & 0.0031 & 0.9027 \\
\hline \multirow[t]{2}{*}{$N$} & 3888 & 2520 & 2520 \\
\hline & \multicolumn{3}{|c|}{ MP vs MS } \\
\hline \multirow{2}{*}{$\begin{array}{l}F_{(1,57)} \\
p \text {-value }\end{array}$} & 6.49 & 11.38 & 0.11 \\
\hline & 0.0109 & 0.0008 & 0.7374 \\
\hline
\end{tabular}

Note: ${ }^{* * *},\left({ }^{* *}\right),\left[{ }^{*}\right]$ indicated significance on 1,5 , and 10 percent level, respectively. Tobit regressions with lower (upper) bound on contributions at 0 (50) and with standard errors corrected for dependence of observations for 58 clusters. 
Table A.14. Tests for differences in contributions in the social dilemma game across treatments by trader matchings (periods 1-6 \& periods 7-18) - OLS with period dummies (cf. Table 4)

\begin{tabular}{|c|c|c|c|}
\hline \multicolumn{4}{|c|}{ Periods 1-6 } \\
\hline \multirow{3}{*}{ Specification } & \multicolumn{3}{|c|}{ dep. var.: contribution to public good } \\
\hline & $(1)$ & $(2)$ & $(3)$ \\
\hline & buyer pairs & seller pairs & mixed pairs \\
\hline \multirow[t]{2}{*}{ Market-partners } & $-6.721^{*}$ & -6.682 & -1.576 \\
\hline & $(3.454)$ & $(4.152)$ & $(4.808)$ \\
\hline \multirow[t]{2}{*}{ Market-strangers } & 0.786 & $7.036^{* *}$ & 3.265 \\
\hline & $(3.068)$ & $(3.328)$ & $(3.318)$ \\
\hline \multirow[t]{2}{*}{ Constant (OSDG) } & $33.370^{* * *}$ & $31.639^{* * *}$ & $32.589^{* * *}$ \\
\hline & $(2.378)$ & $(2.294)$ & $(2.244)$ \\
\hline Period dummies & yes & yes & yes \\
\hline$R^{2}$ & 0.129 & 0.123 & 0.083 \\
\hline \multirow[t]{2}{*}{$N$} & 1296 & 840 & 840 \\
\hline & \multicolumn{3}{|c|}{ MP vs MS } \\
\hline \multirow{2}{*}{$\begin{array}{l}F_{(1,57)} \\
p \text {-value }\end{array}$} & 7.16 & 12.71 & 1.14 \\
\hline & 0.0097 & 0.0007 & 0.2910 \\
\hline \multicolumn{4}{|c|}{ Periods 7-18 } \\
\hline \multirow{3}{*}{ Specification } & dep. var.: & ontribution & public good \\
\hline & $(1)$ & $(2)$ & $(3)$ \\
\hline & buyer pairs & seller pairs & mixed pairs \\
\hline \multirow[t]{2}{*}{ Market-partners } & $-11.156^{* * *}$ & $-9.138^{*}$ & 0.788 \\
\hline & $(4.181)$ & $(4.696)$ & $(5.085)$ \\
\hline \multirow[t]{2}{*}{ Market-strangers } & -1.848 & 5.331 & 0.703 \\
\hline & $(3.387)$ & $(3.490)$ & $(3.795)$ \\
\hline \multirow[t]{2}{*}{ Constant (OSDG) } & $32.778^{* * *}$ & $31.271^{* * *}$ & $31.166^{* * *}$ \\
\hline & $(2.871)$ & $(2.728)$ & $(2.777)$ \\
\hline Period dummies & yes & yes & yes \\
\hline$R^{2}$ & 0.089 & 0.111 & 0.030 \\
\hline \multirow[t]{2}{*}{$N$} & 2592 & 1680 & 1680 \\
\hline & & $\mathrm{MP}$ vs Ms & \\
\hline$F_{(1,57)}$ & 6.65 & 11.46 & 0.00 \\
\hline$p$-value & 0.0125 & 0.0013 & 0.9863 \\
\hline
\end{tabular}

Note: ${ }^{* * *},\left({ }^{* *}\right),\left[{ }^{*}\right]$ indicated significance on 1,5 , and 10 percent level, respectively. OLS regressions with standard errors corrected for dependence of observations for 58 clusters. 
Table A.15. Tests for differences in contributions in the social dilemma game across treatments by trader matchings (periods 1-6 \& periods 7-18) - Tobit regressions (cf. Table 4)

\begin{tabular}{|c|c|c|c|}
\hline \multicolumn{4}{|c|}{ Periods 1-6 } \\
\hline \multirow{3}{*}{ Specification } & dep. var.: & ontribution & public good \\
\hline & $(1)$ & $(2)$ & $(3)$ \\
\hline & buyer pairs & seller pairs & mixed pairs \\
\hline \multirow[t]{2}{*}{ Market-partners } & $-10.550^{*}$ & -9.998 & -1.163 \\
\hline & $(5.485)$ & $(6.691)$ & $(8.700)$ \\
\hline \multirow[t]{2}{*}{ Market-strangers } & 0.174 & $10.667^{*}$ & 6.786 \\
\hline & $(4.963)$ & $(5.710)$ & $(6.095)$ \\
\hline \multirow[t]{2}{*}{ Constant (OSDG) } & $31.623^{* * *}$ & $31.917^{* * *}$ & $32.523^{* * *}$ \\
\hline & $(4.271)$ & $(4.483)$ & $(4.808)$ \\
\hline$F(2, N-2)$ & 3.33 & 5.66 & 0.82 \\
\hline Prob $>F$ & 0.0361 & 0.0036 & 0.4403 \\
\hline \multirow[t]{2}{*}{$N$} & 1296 & 840 & 840 \\
\hline & \multicolumn{3}{|c|}{ MP vs MS } \\
\hline \multirow{2}{*}{$\begin{array}{l}F_{(1,57)} \\
p \text {-value }\end{array}$} & 6.06 & 10.88 & 0.90 \\
\hline & 0.0140 & 0.0010 & 0.3432 \\
\hline \multicolumn{4}{|c|}{ Periods 7-18 } \\
\hline \multirow{3}{*}{ Specification } & dep. var.: & ontribution & public good \\
\hline & $(1)$ & $(2)$ & $(3)$ \\
\hline & buyer pairs & seller pairs & mixed pairs \\
\hline \multirow[t]{2}{*}{ Market-partners } & $-21.238^{* * *}$ & $-18.531^{* *}$ & -0.029 \\
\hline & $(7.769)$ & $(9.697)$ & $(10.889)$ \\
\hline \multirow[t]{2}{*}{ Market-strangers } & -6.021 & 7.284 & 0.527 \\
\hline & $(6.527)$ & $(6.697)$ & $(8.332)$ \\
\hline \multirow[t]{2}{*}{ Constant (OSDG) } & $36.561^{* * *}$ & $36.658^{* * *}$ & $38.148^{* * *}$ \\
\hline & $(5.649)$ & $(5.857)$ & $(6.524)$ \\
\hline$F(2, N-2)$ & 4.22 & 5.01 & 0.00 \\
\hline Prob $>F$ & 0.0148 & 0.0068 & 0.9975 \\
\hline \multirow[t]{2}{*}{$N$} & 2592 & 1680 & 1680 \\
\hline & \multicolumn{3}{|c|}{ MP vs MS } \\
\hline \multirow{2}{*}{$\begin{array}{l}F_{(1,57)} \\
p \text {-value }\end{array}$} & 5.77 & 9.92 & 0.00 \\
\hline & 0.0164 & 0.0017 & 0.9589 \\
\hline
\end{tabular}


Table A.16. Contributions in the social dilemma game: comparing trader matchings within market treatments (all periods) (cf. Table 5)

\begin{tabular}{|c|c|c|}
\hline \multirow{3}{*}{ Specification } & \multicolumn{2}{|c|}{ dep. var.: contribution to public good } \\
\hline & $(1)$ & $(2)$ \\
\hline & Market-partners & Market-strangers \\
\hline \multirow[t]{2}{*}{ buyer-buyer } & $-9.678^{* *}$ & -0.970 \\
\hline & $(3.778)$ & $(3.135)$ \\
\hline \multirow[t]{2}{*}{ seller-seller } & $-8.319^{*}$ & $5.899^{*}$ \\
\hline & $(4.264)$ & $(3.297)$ \\
\hline \multirow[t]{2}{*}{ seller-buyer } & -0.000 & 1.557 \\
\hline & $(4.760)$ & $(3.442)$ \\
\hline \multirow[t]{2}{*}{ Constant (OSDG) } & $29.375^{* * *}$ & $29.375^{* * *}$ \\
\hline & $(2.646)$ & $(2.647)$ \\
\hline$R^{2}$ & 0.058 & 0.018 \\
\hline \multirow[t]{2}{*}{$N$} & 3168 & 4608 \\
\hline & \multicolumn{2}{|c|}{ buyer-buyer vs seller-seller } \\
\hline$F$ & 0.09 & 5.77 \\
\hline \multirow[t]{2}{*}{$p$-value } & 0.7624 & 0.0207 \\
\hline & \multicolumn{2}{|c|}{ buyer-buyer vs seller-buyer } \\
\hline$F$ & 4.32 & 0.62 \\
\hline \multirow[t]{2}{*}{$p$-value } & 0.0433 & 0.4356 \\
\hline & \multicolumn{2}{|c|}{ seller-buyer vs seller-seller } \\
\hline$F$ & 2.58 & 2.30 \\
\hline$p$-value & 0.1150 & 0.1365 \\
\hline
\end{tabular}


Table A.17. Contributions in the social dilemma game: comparing trader matchings within market treatments (all periods) - OLS with period dummies (cf. Tables A.16 and 5)

\begin{tabular}{|c|c|c|}
\hline \multirow{3}{*}{ Specification } & \multicolumn{2}{|c|}{ dep. var.: contribution to public good } \\
\hline & $(1)$ & $(2)$ \\
\hline & Market-partners & Market-strangers \\
\hline \multirow[t]{2}{*}{ buyer-buyer } & $-9.678^{* *}$ & -0.970 \\
\hline & $(3.788)$ & $(3.141)$ \\
\hline \multirow[t]{2}{*}{ seller-seller } & $-8.319^{*}$ & $5.899^{*}$ \\
\hline & $(4.275)$ & $(3.303)$ \\
\hline \multirow[t]{2}{*}{ seller-buyer } & -0.000 & 1.557 \\
\hline & $(4.773)$ & $(3.448)$ \\
\hline \multirow[t]{2}{*}{ Constant (OSDG) } & $34.232^{* * *}$ & $33.696^{* * *}$ \\
\hline & $(2.471)$ & $(2.450)$ \\
\hline Period dummies & yes & yes \\
\hline$R^{2}$ & 0.095 & 0.076 \\
\hline \multirow[t]{2}{*}{$N$} & 3168 & 4608 \\
\hline & \multicolumn{2}{|c|}{ buyer-buyer vs seller-seller } \\
\hline$F$ & 0.09 & 5.75 \\
\hline \multirow{2}{*}{$p$-value } & 0.7630 & 0.0209 \\
\hline & \multicolumn{2}{|c|}{ buyer-buyer vs seller-buyer } \\
\hline$F$ & 4.30 & 0.62 \\
\hline \multirow{2}{*}{$p$-value } & 0.0438 & 0.4364 \\
\hline & \multicolumn{2}{|c|}{ seller-buyer vs seller-seller } \\
\hline$F$ & 2.57 & 2.29 \\
\hline$p$-value & 0.1160 & 0.1372 \\
\hline \multicolumn{3}{|c|}{$\begin{array}{l}\text { Note: }{ }^{* * *},\left({ }^{* *}\right),\left[{ }^{*}\right] \text { indicated significance on } 1,5 \text {, and } 10 \text { percent level, re } \\
\text { spectively. OLS regressions with standard errors corrected for dependence } \\
\text { of observations for respectively } 46 \text { and } 44 \text { clusters in specification }(1) \text { and } \\
(2) . F \text {-test is } F_{1,45}\left(F_{1,43}\right) \text { for market-partners (market-strangers). }\end{array}$} \\
\hline
\end{tabular}


Table A.18. Contributions in the social dilemma game: comparing trader matchings within market treatments (all periods) - Tobit regressions (cf. Tables A.16 and 5)

\begin{tabular}{lcc}
\hline \hline \multirow{2}{*}{ Specification } & \multicolumn{2}{c}{ dep. var.: contribution to public good } \\
\cline { 2 - 3 } & $(1)$ & $(2)$ \\
& Market-partners & Market-strangers \\
\hline buyer-buyer & $-17.698^{* * *}$ & -4.002 \\
seller-seller & $(6.657)$ & $(5.617)$ \\
& $-15.498^{* *}$ & 8.617 \\
seller-buyer & $(7.789)$ & $(6.283)$ \\
& -0.261 & 2.693 \\
Constant (OSDG) & $(8.944)$ & $(6.668)$ \\
& $35.005^{* * *}$ & $35.215^{* * *}$ \\
$F(3, N-3)$ & $(5.150)$ & $(5.161)$ \\
Prob $>F$ & 3.56 & 1.69 \\
$N$ & 0.0138 & 0.167 \\
& 3168 & 4608 \\
$F$ & buyer-buyer vs seller-seller \\
$p$-value & 0.08 & 4.99 \\
& 0.7830 & 0.0255 \\
$F$ & buyer-buyer vs seller-buyer \\
$p$-value & 4.33 & 1.18 \\
& 0.0376 & 0.2777 \\
$F$ & seller-buyer vs seller-seller \\
$p$-value & 2.60 & 0.98 \\
& 0.1067 & 0.3228 \\
\cline { 2 - 3 }$N o t:$ & &
\end{tabular}

Note: ${ }^{* * *},\left({ }^{* *}\right),\left[{ }^{*}\right]$ indicated significance on 1,5 , and 10 percent level, respectively. Tobit regressions with lower (upper) bound on contributions at 0 (5) and standard errors corrected for dependence of observations for respectively 46 and 44 clusters in specification (1) and (2). F-test is $F_{1,45}$ $\left(F_{1,43}\right)$ for market-partners (market-strangers). 
Table A.19. Contributions in the social dilemma game: comparing trader matchings within market treatments (periods 1-6)

\begin{tabular}{|c|c|c|}
\hline \multirow{3}{*}{ Specification } & \multicolumn{2}{|c|}{ dep. var.: contribution to public good } \\
\hline & $(1)$ & $(2)$ \\
\hline & Market-partners & Market-strangers \\
\hline \multirow[t]{2}{*}{ buyer-buyer } & $-6.721^{*}$ & -0.786 \\
\hline & $(3.345)$ & $(3.071)$ \\
\hline \multirow[t]{2}{*}{ seller-seller } & -6.683 & $7.036^{* *}$ \\
\hline & $(4.150)$ & $(3.327)$ \\
\hline \multirow[t]{2}{*}{ seller-buyer } & -1.576 & 3.265 \\
\hline & $(4.806)$ & $(3.316)$ \\
\hline \multirow[t]{2}{*}{ Constant (OSDG) } & $28.451^{* * *}$ & $28.451^{* * *}$ \\
\hline & $(2.597)$ & $(2.597)$ \\
\hline$R^{2}$ & 0.030 & 0.020 \\
\hline \multirow[t]{2}{*}{$N$} & 1056 & 1536 \\
\hline & \multicolumn{2}{|c|}{ buyer-buyer vs seller-seller } \\
\hline$F$ & 0.00 & 4.42 \\
\hline \multirow[t]{2}{*}{$p$-value } & 0.9919 & 0.0414 \\
\hline & \multicolumn{2}{|c|}{ buyer-buyer vs seller-buyer } \\
\hline$F$ & 1.68 & 0.63 \\
\hline \multirow[t]{2}{*}{$p$-value } & 0.2020 & 0.4316 \\
\hline & \multicolumn{2}{|c|}{ seller-buyer vs seller-seller } \\
\hline$F$ & 0.98 & 2.32 \\
\hline$p$-value & 0.3272 & 0.1349 \\
\hline
\end{tabular}


Table A.20. Contributions in the social dilemma game: comparing trader matchings within market treatments (periods 7-18)

\begin{tabular}{|c|c|c|}
\hline \multirow{3}{*}{ Specification } & \multicolumn{2}{|c|}{ dep. var.: contribution to public good } \\
\hline & $(1)$ & $(2)$ \\
\hline & Market-partners & Market-strangers \\
\hline \multirow[t]{2}{*}{ buyer-buyer } & $-11.156^{* *}$ & -1.848 \\
\hline & $(4.183)$ & $(3.390)$ \\
\hline \multirow[t]{2}{*}{ seller-seller } & $-9.138^{*}$ & 5.331 \\
\hline & $(4.692)$ & $(3.488)$ \\
\hline \multirow[t]{2}{*}{ seller-buyer } & 0.788 & 0.703 \\
\hline & $(5.081)$ & $(3.792)$ \\
\hline \multirow[t]{2}{*}{ Constant (OSDG) } & $29.837^{* * *}$ & $28.837^{* * *}$ \\
\hline & $(2.823)$ & $(2.824)$ \\
\hline$R^{2}$ & 0.075 & 0.018 \\
\hline \multirow[t]{2}{*}{$N$} & 2112 & 3072 \\
\hline & \multicolumn{2}{|c|}{ buyer-buyer vs seller-seller } \\
\hline$F$ & 0.15 & 5.52 \\
\hline \multirow[t]{2}{*}{$p$-value } & 0.7025 & 0.0234 \\
\hline & \multicolumn{2}{|c|}{ buyer-buyer vs seller-buyer } \\
\hline$F$ & 5.35 & 0.54 \\
\hline \multirow[t]{2}{*}{$p$-value } & 0.0253 & 0.4656 \\
\hline & \multicolumn{2}{|c|}{ seller-buyer vs seller-seller } \\
\hline$F$ & 2.87 & 1.85 \\
\hline$p$-value & 0.0970 & 0.1810 \\
\hline
\end{tabular}


Table A.21. Contributions in the social dilemma game: comparing trader matchings within market treatments and earnings matchings within OSDG-I (all periods) (cf. page 30)

\begin{tabular}{|c|c|c|}
\hline \multirow{3}{*}{ Specification } & \multicolumn{2}{|c|}{ dep. var.: contribution to public good } \\
\hline & $(1)$ & $(2)$ \\
\hline & Market-partners \& OSDG-I & Market-strangers \& OSDG-I \\
\hline \multirow[t]{2}{*}{ buyer-buyer } & $-9.678^{* *}$ & -0.970 \\
\hline & $(3.760)$ & $(3.119)$ \\
\hline \multirow[t]{2}{*}{ seller-seller } & $-8.319^{*}$ & $5.899^{*}$ \\
\hline & $(4.244)$ & $(3.281)$ \\
\hline \multirow[t]{2}{*}{ seller-buyer } & -0.000 & 1.557 \\
\hline & $(4.738)$ & $(3.425)$ \\
\hline \multirow[t]{2}{*}{ low-low } & 4.065 & 3.940 \\
\hline & $(4.399)$ & $(4.117)$ \\
\hline \multirow[t]{2}{*}{ high-high } & 3.139 & -0.347 \\
\hline & $(4.791)$ & $(4.294)$ \\
\hline \multirow[t]{2}{*}{ high-low } & 1.005 & 0.088 \\
\hline & $(5.178)$ & $(5.063)$ \\
\hline \multirow[t]{2}{*}{ Constant (OSDG) } & $29.375^{* * *}$ & $29.375^{* * *}$ \\
\hline & $(2.634)$ & $(2.634)$ \\
\hline$R^{2}$ & 0.058 & 0.016 \\
\hline \multirow[t]{2}{*}{$N$} & 4464 & 5904 \\
\hline & \multicolumn{2}{|c|}{ high-high vs high-low } \\
\hline$F$ & 0.13 & 0.01 \\
\hline \multirow[t]{2}{*}{$p$-value } & 0.7226 & 0.9371 \\
\hline & \multicolumn{2}{|c|}{ high-high vs low-low } \\
\hline$F$ & 0.03 & 0.85 \\
\hline \multirow[t]{2}{*}{$p$-value } & 0.8626 & 0.3581 \\
\hline & \multicolumn{2}{|c|}{ high-low vs low-low } \\
\hline$F$ & 0.29 & 0.52 \\
\hline \multirow[t]{2}{*}{$p$-value } & 0.5917 & 0.4743 \\
\hline & \multicolumn{2}{|c|}{ high-high vs seller-seller } \\
\hline$F$ & 4.85 & 2.55 \\
\hline \multirow[t]{2}{*}{$p$-value } & 0.0305 & 0.1146 \\
\hline & \multicolumn{2}{|c|}{ low-low vs buyer-buyer } \\
\hline$F$ & 9.63 & 1.88 \\
\hline \multirow[t]{2}{*}{$p$-value } & 0.0026 & 0.1738 \\
\hline & \multicolumn{2}{|c|}{ high-low vs seller-buyer } \\
\hline$F$ & 0.03 & 0.09 \\
\hline$p$-value & 0.8663 & 0.7626 \\
\hline $\begin{array}{l}\text { Note: }{ }^{* * *},\left({ }^{* *}\right),\left[{ }^{*}\right] \text { ind } \\
\text { sions with standard er } \\
\text { clusters in specification } \\
\text { low-low, high-high, an } \\
\text { and 2656-2656, 346-34 }\end{array}$ & $\begin{array}{l}\text { ated significance on } 1,5 \text {, and } 10 \mathrm{p} \\
\text { ors corrected for dependence of ob } \\
\text { (1) and (2). F-test is } F_{1,45}\left(F_{1,43}\right) \mathrm{fc} \\
\text { high-low stands for } 2672-2672,340- \\
\text { and 2656-346 in market-strangers. }\end{array}$ & $\begin{array}{l}\text { cent level, respectively. OLS regres- } \\
\text { ervations for respectively } 46 \text { and } 44 \\
\text { market-partners (market-strangers). } \\
\text { 40, and 2672-340 in market-partners }\end{array}$ \\
\hline
\end{tabular}


Table A.22. Contributions in the social dilemma game: comparing trader matchings within market treatments and earnings matchings within OSDG-I (all periods) - OLS with period dummies (cf. Table A.21)

\begin{tabular}{|c|c|c|}
\hline \multirow{3}{*}{ Specification } & \multicolumn{2}{|c|}{ dep. var.: contribution to public good } \\
\hline & $(1)$ & $(2)$ \\
\hline & Market-partners \& OSDG-I & Market-strangers \& OSDG-I \\
\hline \multirow[t]{2}{*}{ buyer-buyer } & $-9.678^{* *}$ & -0.970 \\
\hline & $(3.767)$ & $(3.124)$ \\
\hline \multirow[t]{2}{*}{ seller-seller } & $-8.319^{*}$ & $5.899^{*}$ \\
\hline & $(4.252)$ & $(3.285)$ \\
\hline \multirow[t]{2}{*}{ seller-buyer } & -0.000 & 1.557 \\
\hline & $(4.747)$ & $(3.430)$ \\
\hline \multirow[t]{2}{*}{ low-low } & 4.065 & 3.940 \\
\hline & $(4.408)$ & $(4.123)$ \\
\hline \multirow[t]{2}{*}{ high-high } & 3.139 & -0.347 \\
\hline & $(4.800)$ & $(4.300)$ \\
\hline \multirow[t]{2}{*}{ high-low } & 1.005 & 0.088 \\
\hline & $(5.188)$ & $(5.070)$ \\
\hline \multirow[t]{2}{*}{ Constant (OSDG) } & $32.794^{* * *}$ & $32.548^{* * *}$ \\
\hline & $(2.529)$ & $(2.511)$ \\
\hline Period dummies & yes & yes \\
\hline$R^{2}$ & 0.105 & 0.070 \\
\hline \multirow[t]{2}{*}{$N$} & 4464 & 5904 \\
\hline & \multicolumn{2}{|c|}{ high-high vs high-low } \\
\hline \multirow{3}{*}{$\begin{array}{l}F \\
p \text {-value }\end{array}$} & 0.13 & 0.01 \\
\hline & 0.7231 & 0.9372 \\
\hline & \multicolumn{2}{|c|}{ high-high vs low-low } \\
\hline$F$ & 0.03 & 0.85 \\
\hline \multirow[t]{2}{*}{$p$-value } & 0.8628 & 0.3588 \\
\hline & \multicolumn{2}{|c|}{ high-low vs low-low } \\
\hline$F$ & 0.29 & 0.52 \\
\hline \multirow[t]{2}{*}{$p$-value } & 0.5924 & 0.4749 \\
\hline & \multicolumn{2}{|c|}{ high-high vs seller-seller } \\
\hline$F$ & 4.83 & 2.54 \\
\hline \multirow[t]{2}{*}{$p$-value } & 0.0309 & 0.1151 \\
\hline & \multicolumn{2}{|c|}{ low-low vs buyer-buyer } \\
\hline$F$ & 9.59 & 1.88 \\
\hline \multirow[t]{2}{*}{$p$-value } & 0.0027 & 0.1744 \\
\hline & \multicolumn{2}{|c|}{ high-low vs seller-buyer } \\
\hline$F$ & 0.03 & 0.09 \\
\hline$p$-value & 0.8666 & 0.7630 \\
\hline $\begin{array}{l}\left.\text { Note: }{ }^{* * *},\left({ }^{* *}\right),{ }^{*}\right] \text { ind } \\
\text { sions with standard er } \\
\text { clusters in specification } \\
\text { low-low, high-high, an } \\
\text { and } 2656-2656,346-34\end{array}$ & $\begin{array}{l}\text { ated significance on } 1,5 \text {, and } 10 \mathrm{p} \\
\text { ors corrected for dependence of ob } \\
\text { (1) and (2). F-test is } F_{1,45}\left(F_{1,43}\right) \mathrm{fc} \\
\text { high-low stands for } 2672-2672,340\end{array}$ & $\begin{array}{l}\text { cent level, respectively. OLS regres- } \\
\text { ervations for respectively } 46 \text { and } 44 \\
\text { market-partners (market-strangers). } \\
\text { 40, and } 2672-340 \text { in market-partners }\end{array}$ \\
\hline
\end{tabular}


Table A.23. Contributions in the social dilemma game: comparing trader matchings within market treatments and earnings matchings within OSDG-I (all periods) - Tobit regressions (cf. Table A.21)

\begin{tabular}{|c|c|c|}
\hline \multirow{3}{*}{ Specification } & \multicolumn{2}{|c|}{ dep. var.: contribution to public good } \\
\hline & $(1)$ & $(2)$ \\
\hline & Market-partners \& OSDG-I & Market-strangers \& OSDG-I \\
\hline \multirow[t]{2}{*}{ buyer-buyer } & $-18.474^{* * *}$ & -3.968 \\
\hline & $(6.922)$ & $(5.863)$ \\
\hline \multirow[t]{2}{*}{ seller-seller } & $-16.194^{* *}$ & 8.592 \\
\hline & $(8.102)$ & $(6.222)$ \\
\hline \multirow[t]{2}{*}{ seller-buyer } & -0.291 & 2.682 \\
\hline & $(9.296)$ & $(6.603)$ \\
\hline \multirow[t]{2}{*}{ low-low } & 7.324 & 4.226 \\
\hline & $(9.294)$ & $(7.523)$ \\
\hline \multirow[t]{2}{*}{ high-high } & 5.939 & -1.321 \\
\hline & $(10.033)$ & $(7.590)$ \\
\hline \multirow[t]{2}{*}{ high-low } & 1.669 & 0.204 \\
\hline & $(10.161)$ & $(9.423)$ \\
\hline \multirow[t]{2}{*}{ Constant (OSDG) } & $35.566^{* * *}$ & $35.150^{* * *}$ \\
\hline & $(5.296)$ & $(5.065)$ \\
\hline$F(6, N-6)$ & 3.25 & 0.94 \\
\hline Prob $>F$ & 0.0034 & 0.4630 \\
\hline \multirow[t]{2}{*}{$N$} & 4464 & 5904 \\
\hline & \multicolumn{2}{|c|}{ high-high vs high-low } \\
\hline$F$ & 0.12 & 0.02 \\
\hline \multirow{2}{*}{$p$-value } & 0.7301 & 0.8775 \\
\hline & \multicolumn{2}{|c|}{ high-high vs low-low } \\
\hline \multirow{3}{*}{$\begin{array}{l}F \\
p \text {-value }\end{array}$} & 0.01 & 0.47 \\
\hline & 0.9055 & 0.4933 \\
\hline & \multicolumn{2}{|c|}{ high-low vs low-low } \\
\hline$F$ & 0.23 & 0.17 \\
\hline \multirow[t]{2}{*}{$p$-value } & 0.6315 & 0.6829 \\
\hline & \multicolumn{2}{|c|}{ high-high vs seller-seller } \\
\hline$F$ & 4.30 & 2.04 \\
\hline \multirow[t]{2}{*}{$p$-value } & 0.0381 & 0.1528 \\
\hline & \multicolumn{2}{|c|}{ low-low vs buyer-buyer } \\
\hline$F$ & 8.16 & 1.60 \\
\hline \multirow[t]{2}{*}{$p$-value } & 0.0043 & 0.2060 \\
\hline & \multicolumn{2}{|c|}{ high-low vs seller-buyer } \\
\hline$F$ & 0.03 & 0.07 \\
\hline$p$-value & 0.8676 & 0.7869 \\
\hline $\begin{array}{l}\text { Note: }{ }^{* * *},\left({ }^{* *}\right),\left[{ }^{*}\right] \text { ir } \\
\text { regressions with lower } \\
\text { dependence of observa } \\
\text { is } F_{1,45}\left(F_{1,43}\right) \text { for ma } \\
\text { for } 2672-2672,340-340 \\
\text { in market-strangers. }\end{array}$ & $\begin{array}{l}\text { dicated significance on } 1,5 \text {, and } \\
\text { upper) bound of contributions at } 0 \\
\text { ons for respectively } 46 \text { and } 44 \text { clust } \\
\text { set-partners (market-strangers). lor } \\
\text { and 2672-340 in market-partners a }\end{array}$ & $\begin{array}{l}\text { percent level, respectively. Tobit } \\
\text { 5) and standard errors corrected for } \\
\text { s in specification (1) and (2). F-test } \\
\text { low, high-high, and high-low stands } \\
\text { d 2656-2656,346-346, and 2656-346 }\end{array}$ \\
\hline
\end{tabular}




\section{A.2 Subjective well-being and social value orientation - additional statistics}

Table A.24. Subjective well-being and social value orientation: descriptive statistics of initial and final values as well as changes) (cf. Table 7)

\begin{tabular}{|c|c|c|c|c|c|c|}
\hline \multirow[b]{2}{*}{ Treatment } & \multicolumn{3}{|c|}{ Initial subjective well-being } & \multicolumn{3}{|c|}{ Initial social value orientation } \\
\hline & Mean & St.Dev. & $\mathrm{N}$ & Mean & St.Dev. & $\mathrm{N}$ \\
\hline Market-partners & 3.196 & 1.749 & 112 & 11.571 & 26.660 & 112 \\
\hline Market-strangers & 2.911 & 1.594 & 192 & 17.659 & 20.386 & 192 \\
\hline \multirow[t]{2}{*}{ OSDG } & 2.922 & 1.525 & 64 & 21.876 & 21.164 & 64 \\
\hline & \multicolumn{3}{|c|}{ Final subjective well-being } & \multicolumn{3}{|c|}{ Final social value orientation } \\
\hline Treatment & Mean & St.Dev. & $\mathrm{N}$ & Mean & St.Dev. & $\mathrm{N}$ \\
\hline Market-partners & 3.696 & 2.265 & 112 & 9.124 & 19.312 & 112 \\
\hline Market-strangers & 3.641 & 2.347 & 192 & 11.627 & 21.165 & 192 \\
\hline \multirow[t]{2}{*}{ OSDG } & 3.156 & 1.720 & 64 & 17.338 & 21.512 & 64 \\
\hline & \multicolumn{3}{|c|}{ Change in subjective well-being } & \multicolumn{3}{|c|}{ Change in social value orientation } \\
\hline Treatment & Mean & St.Dev. & $\mathrm{N}$ & Mean & St.Dev. & $\mathrm{N}$ \\
\hline Market-partners & -0.500 & 2.344 & 112 & -2.447 & 17.619 & 112 \\
\hline Market-strangers & -0.729 & 2.599 & 192 & -6.031 & 19.259 & 192 \\
\hline OSDG & -0.234 & 1.771 & 64 & -4.538 & 13.682 & 64 \\
\hline
\end{tabular}

Note: For subjective well-being a higher value indicates worse well-being; change in subjective well-being is initial - final. For social value orientation higher degrees (smaller 90 degree) indicate stronger pro-social value orientation; change in social value orientation is final - initial. 


\section{B Experiment Instructions}

This section contains the original Spanish versions of the general instructions, which were read aloud at the beginning of a session and which were the same in all treatments, the specific instructions and screen-shots of market-partners and the specific instructions and screen-shots of market-strangers. In addition a complete English translation is provided of the general instructions and the specific instructions and screen-shots of market-strangers.

The instructions of OSDG are identical to the instructions of the SDG in market-partners and market-strangers, respectively. The instructions for OSDG-I are identical to the instructions of OSDG, except for the difference in the announcement of the lump-sum payment at the beginning of the experiment. These instructions are available from the authors upon request.

B.1 


\section{General Instructions (original Spanish version)}

\section{INSTRUCCIONES}

Bienvenido al experimento. El propósito de este experimento es estudiar cómo toman los individuos decisiones en diferentes situaciones. Las instrucciones son simples y si las sigues cuidadosamente puedes ganar una considerable cantidad de dinero con las decisiones que tomes. La cantidad que ganes puede también depender de las decisiones de los demás participantes y de sucesos aleatorios. La cantidad total de dinero que ganes en el experimento se te pagará en efectivo de manera confidencial al final del experimento. Nadie conocerá los pagos recibidos por el resto de participantes. Durante el experimento podéis hacer preguntas en cualquier momento. Podéis preguntarnos en cualquier momento las dudas que tengáis levantando primero la mano. Fuera de esas preguntas, cualquier tipo de comunicación entre vosotros distinta de la especificada en las instrucciones no está permitida y puede llevar a la exclusión inmediata del experimento.

1. Este experimento consta de varias partes. Estas son las instrucciones Generales para todas las partes del experimento. Recibirás las instrucciones para las diferentes partes al inicio de cada una de las partes.

2. En algunas partes conocerás (partes) de tus ingresos, pero en otras no conocerás tus ingresos inmediatamente. Sólo al final del experimento se te informará de los ingresos que hayas obtenido en cada parte y de los ingresos totales. En el experimento no hablaremos de Euros sino de ECUs. Al final del experimento, todos los ingresos que hayas obtenido en este experimento se cambiarán a la tasa de cambio de 100 ECUs $=€ 1$.

3. Al principio de cada parte del experimento verás en pantalla las instrucciones correspondientes. 


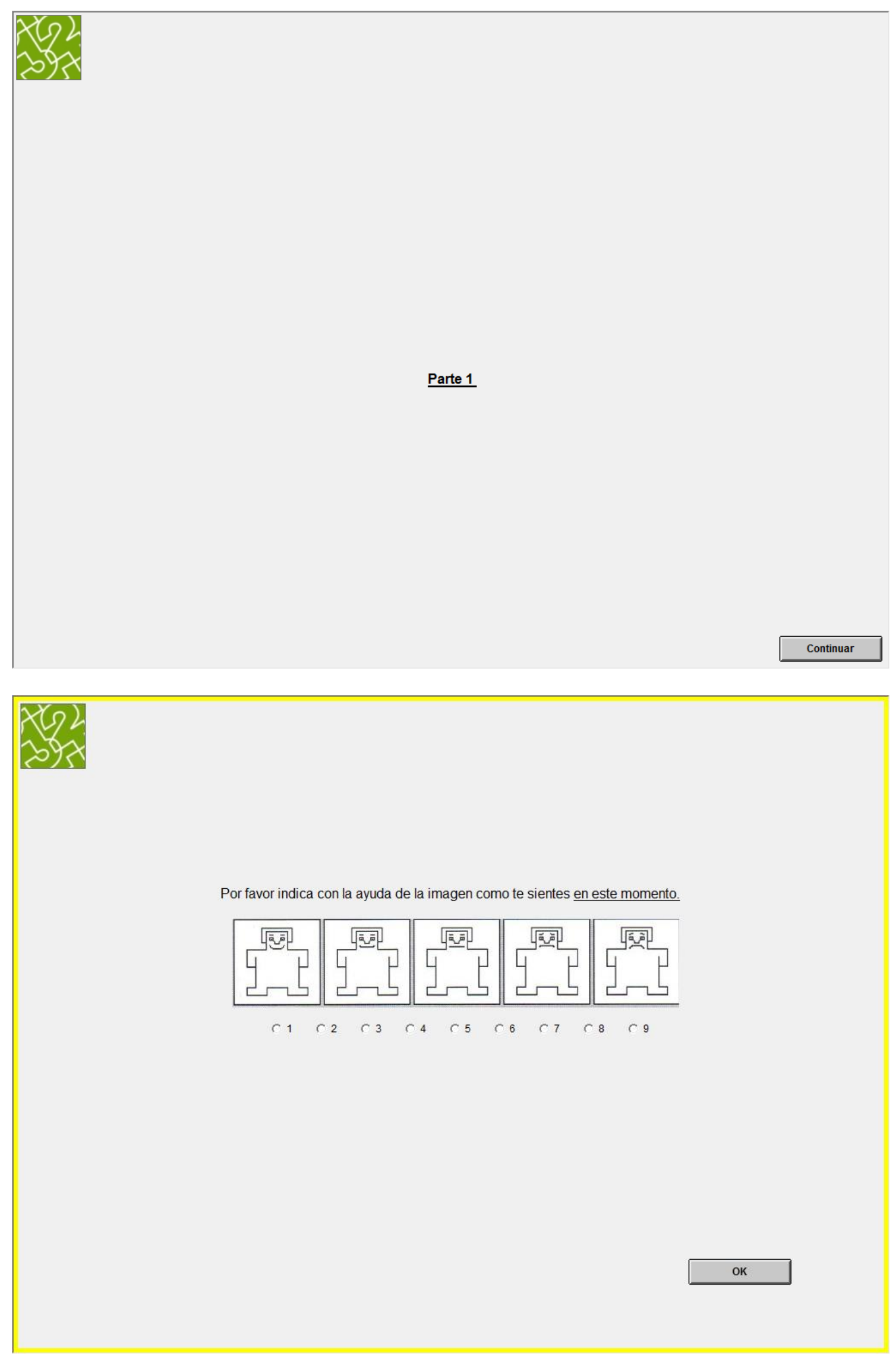

B.3 
Parte 2: Cirrculo

Ronda de Prueba

\section{Instrucciones}

1. En esta parte del experimento vas a tomar una única decisión. Tu decisión consiste en elegir una distribución de ECUs entre tú y otro participante. El otro participante lo seleccionará el servidor de manera aleatoria y no vas a interactuar con él/ella en ninguna otra parte del experimento. Además, este emparejamiento no es recíproco, esto es, el participante al que le asignas una cantidad de ECUs con tu decisión no es el mismo que el que te asigna una cantidad de ECUs a ti.

2. En la pantalla verás una circunferencia. Seleccionando un punto de esta circunferencia asignas una cantidad de ECUs para ti y una para el otro participante. Cada punto de la circunferencia corresponde a una cantidad que será sumada ( 0 restada) de tus ingresos y a una cantidad que será sumada (o restada) de los ingresos del participante con el que estás conectado. Tomando esta decisión puedes incrementar (o reducir) tus ingresos y los del otro participante. Las conectado. Tomando esta decisión puedes incrementar (o reducir) tus ingre
distribuciones factibles están comprendidas entre +200 ECUs y -200 ECUs

3. Con la ayuda del ratón podrás hacer "click" en cualquier punto de la circunferencia. Al hacer eso se dibujará una flecha que unirá el centro de la circunferencia con el punto que hayas seleccionado. Además, debajo de la circunferencia se te mostrarán las cantidades exactas de ECUs que has seleccionado para ti y para el otro participante con el que estás conectado.

4. Tus ingresos en esta parte se determinarán por tu decisión (la cantidad de ECUs que te asignas a ti mismo), y por los ECUs que te asigne el participante que está conectado contigo. Recuerda que este no es el mismo al que tu asignas ECUs con tu decisión. Concretamente tus ingresos en esta parte serán la suma de esas dos cantidades.

NOTA: Las cantidades pueden ser positivas y negativas. Puede darse el caso de que la cantidad resultante de la suma de las dos cantidades sea negativa.

5. Podrás cambiar tu decisión hasta que estés satisfecho con tu decisión clickando en distintos puntos. Cuandos estés satisfecho de tu decisión, confirmala pulsando el botón OK 
Con la ayuda del ratón, selecciona un punto de la circunferencia. Recuerda que puedes cambiar de decisión tantas veces como desees. Cuando hayas terminado pulsa OK.

NOTA- Recuerda que no vas a interactuar con el participante al que le asignas ECUs en ninguna otra parte del experimento, y que no es posible la reciprocidad en el emparejamiento.

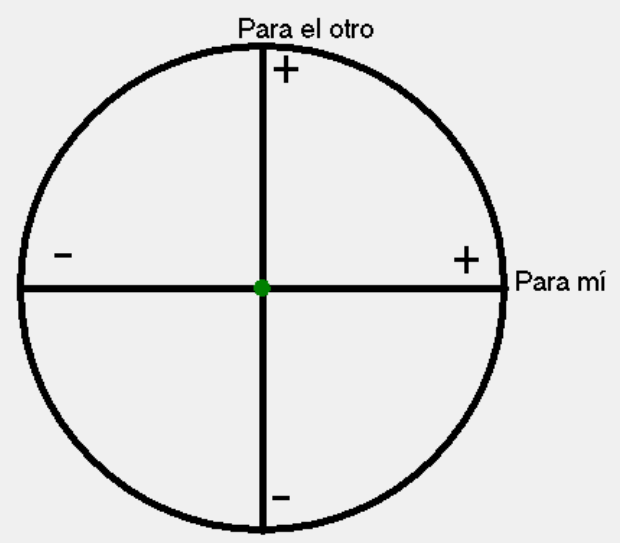

Para mí: 0.00 ECUs

Para el otro: $0.00 \mathrm{ECU}$

Parte 2: Círculo.

Decisión 
Con la ayuda del ratón, selecciona un punto de la circunferencia. Recuerda que puedes cambiar de decisión tantas veces como desees. Cuando hayas terminado pulsa OK.

NOTA: Recuerda que no vas a interactuar con el participante al que le asignas ECUs en ninguna otra parte del experimento, y que no es posible la reciprocidad en el emparejamiento.

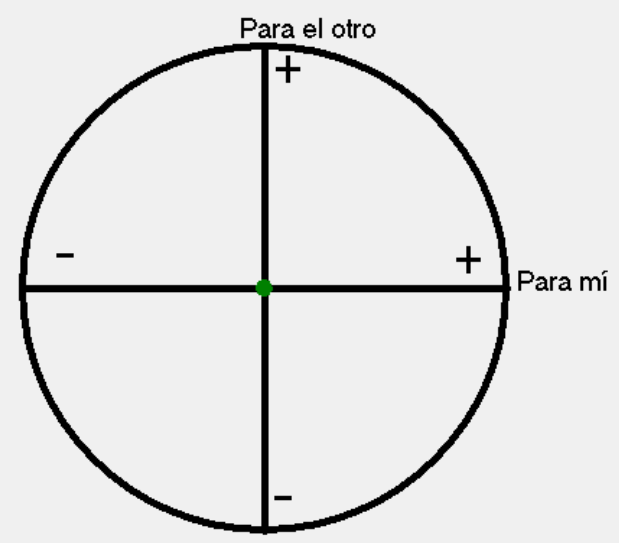

Para mí: 0.00 ECUs

Para el otro: $0.00 \mathrm{ECU}$

Parte 3: Mercados 


\section{COMPRADORES}

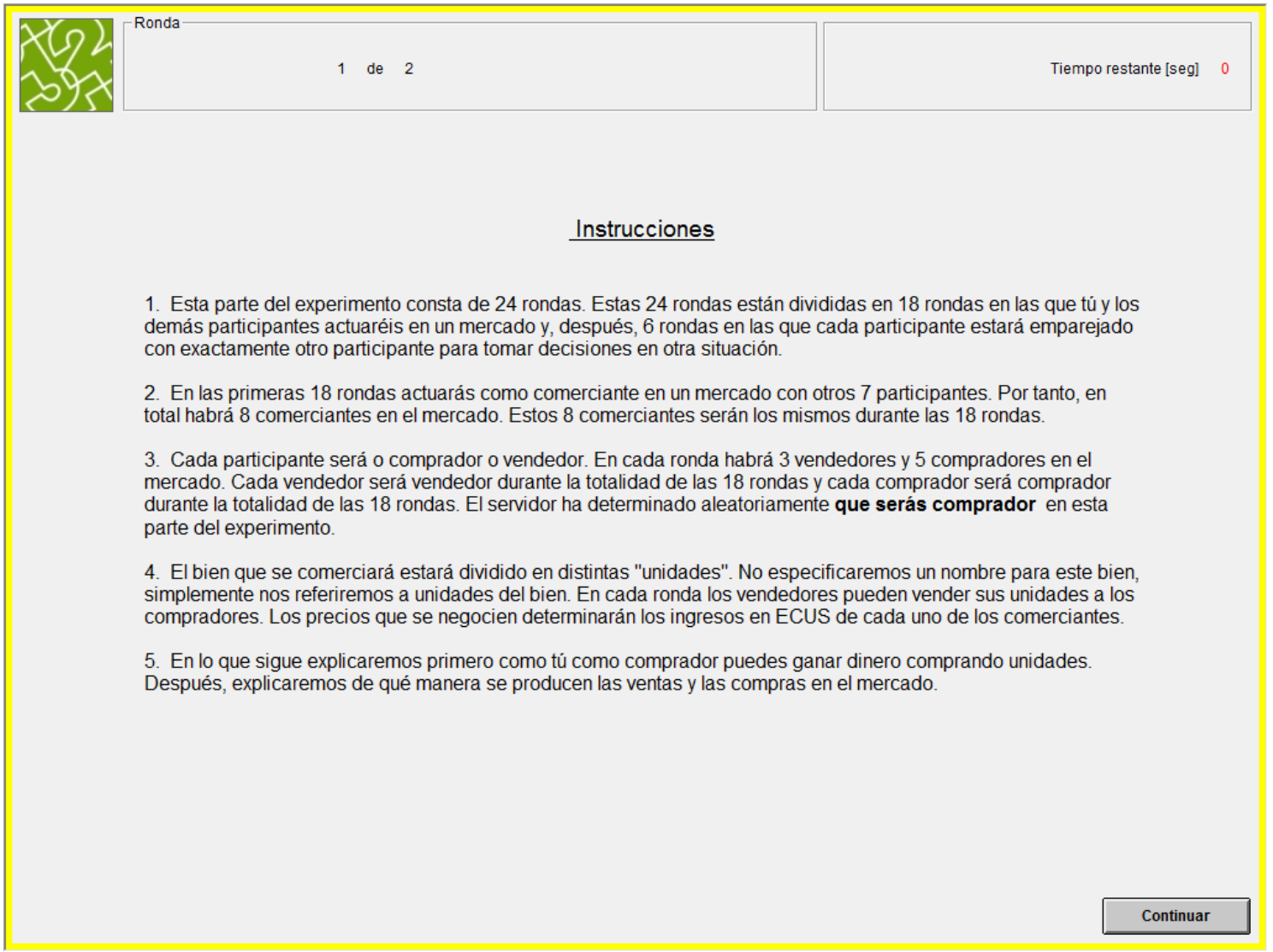

Unidades a comprar y valores de los compradores:

En cada ronda, cada comprador puede comprar hasta 2 unidades, pero es libre de no comprar ninguna o de comprar sólo una. Por cada unidad comprada durante una ronda un comprador recibe un valor de comprador de 100 ECUs. Por una unidad que un comprador no compre el comprador no recibe ningún valor de comprador para esa unidad.

Ingresos de un comprador

Los compradores ganan dinero comprando unidades a precios por debajo de sus valores de comprador. Estas ganancias se computan restando el precio de cada unidad de su valor de comprador. Por tanto,

Ingresos del comprador de la unidad $=100$ - precio de compra de la unidad

Si un comprador no compra ninguna unidad en una ronda, este comprador no gana ningún ECU en esa ronda

Por cada unidad que un vendedor venda el vendedor tiene que pagar un coste de venta y puede ganar dinero vendiendo la unidad a un precio superior al coste de venta. En cada ronda, cada vendedor puede vender hasta 2 unidades, pero puede también vender sólo una unidad o no vender ninguna. Si un vendedor no vende ninguna unidad en una ronda, este vendedor no gana ningún ECU en esa ronda.

Los precios a los que vendedores y compradores pueden comerciar son todos los números enteros entre $10 \mathrm{y}$ 95. Es decir, los precios a los que está permitido comerciar son $10,11,12,13,14, \ldots 92,93,94,95$

6. Cada ronda durará un máximo de 3 minutos. Las unidades que al final de los 3 minutos no se hayan intercambiado se pierden, es decir, no pasan a la ronda siguiente.

7. Los valores de los compradores y los costes de los vendedores son información privada y no serán revelados ni durante ni después del experimento. 
-Ronda

Reglas para hacer transacciones:

En cada ronda valen las siguientes reglas para hacer transacciones:

1. Los compradores hacen ofertas de compra y los vendedores hacen ofertas de venta. Una oferta de un comprador consiste en ofrecer un precio al que comprar. Una oferta de un vendedor consiste en ofrecer un precio al que vender

2. Solamente la oferta de compra más alta y la oferta de venta más baja son los denominados precios pendientes a los que pueden tener lugar las transacciones.

3. El precio de transacción es siempre el precio de la oferta de compra (venta) pendiente. Se produce una transacción si una oferta de compra (venta) pendiente es aceptada por un vendedor (comprador). Para ello hay que seleccionar la oferta pendiente y hacer click en Comprar (Vender).

4. Nuevas ofertas de precios tienen que ser mejoras. Es decir, una nueva oferta de compra (venta) tiene que ser superior (inferior) al precio de la oferta de compra (venta) pendiente.

5. Si se produce una transacción el mercado se vacia y cualquier precio de oferta de compra o de oferta de venta en el intervalo factible vuelve a ser posible. Observa que los precios de ofertas de compra (de ofertas de venta) tienen que ser iguales o inferiores (superiores) al correspondiente valor del comprador (coste de venta del vendedor).

6. Las unidades del bien se comercian una a una. Es decir, no se pueden ofertar ni comerciar varias unidades a la vez

A continuación se muestra un ejemplo

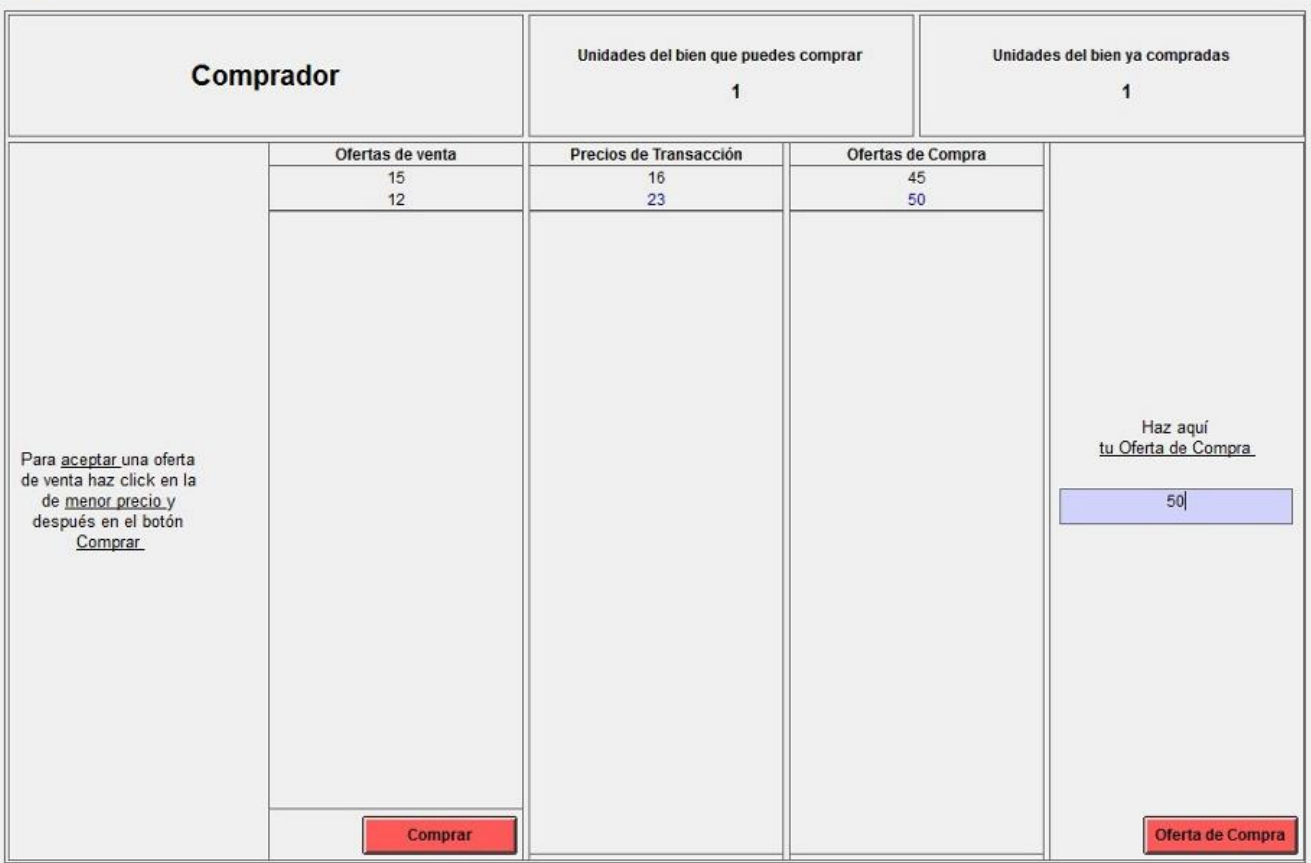

Pulsa a Continuar para ver la explicación 
Esta es una pantalla de ejemplo de un comprador en un mercado en el que se han realizado dos ofertas de venta (columna izquierda), dos transacciones (columna central) y dos ofertas de compra (columna derecha).

En la fila superior, se muestra como este comprador ya ha comprado una unidad del bien, y por tanto le queda aún otra unidad del bien que puede comprar.

\section{Ofertas de venta}

Un vendedor ha realizado una oferta de venta de 15. Posteriormente otro vendedor (o el mismo que realizó la anterior) ha realizado una oferta de venta 12. El precio pendiente es el de menor precio, en este caso 12

\section{Precios transacción}

Este comprador ya ha realizado una transacción (Compra) por un valor de 23 ECUs (valor resaltado en azul). Otros participantes de tu mercado han realizado una transacción por el valor de 16 ECUs

\section{Ofertas de compra}

Otro comprador ha realizado una oferta de compra de 45 ECUs. Posteriormente el comprador del ejemplo ha realizado una oferta de 50 ECUs (resaltada en azul). El precio pendiente es 50.

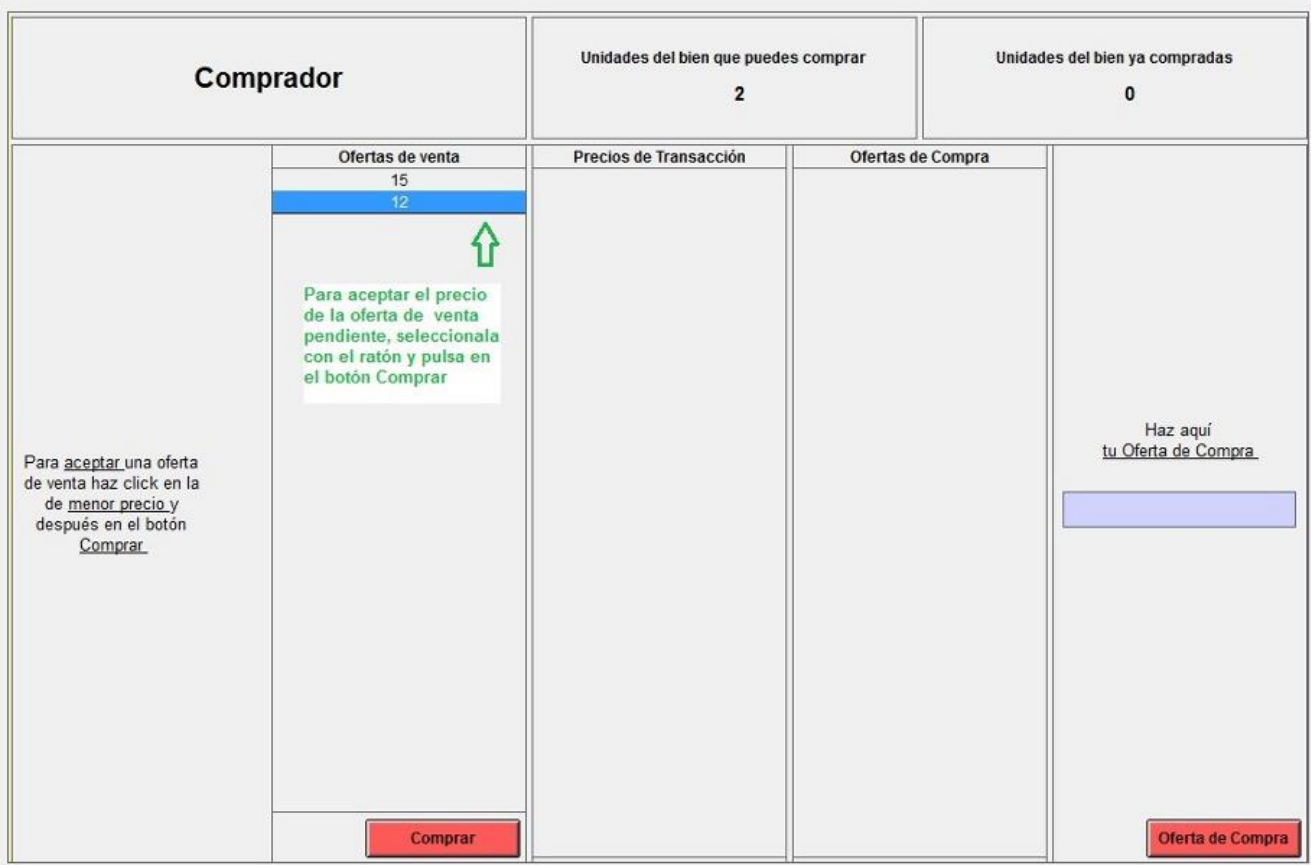

Esta pantalla te recuerda como aceptar la oferta de venta pendiente. 
Este es el final de las instrucciones para el mercado en el que actuarás como comerciante. Este mercado durará 18 rondas. Después de 18 rondas participarás durante otras 6 rondas (las rondas 19 a 24) en otra situación de toma de decisiones. Esto se explicará a continuación.

7. En cada uno de las rondas después del mercado, estarás emparejado con otro participante. Este participante será el mismo durante las 6 rondas. Serás emparejado con otro comprador de otro mercado con el que no has interactuado en el mercado.

8. En cada ronda, cada participante recibe una asignación de 50 ECUs. En cada ronda la decisión a tomar es cuánto asignar a un fondo $\mathrm{A}$ y cuánto a un fondo $\mathrm{B}$. En cada ronda, tendrás que decidir cuantos ECUs depositar en el fondo $B$ y el resto será asignado automáticamente al fondo $A$

9. Por cada ECU que asignes al fondo $A$ tus ingresos aumentarán en 1 ECU

10. Por cada ECU que asignes al Fondo B tus ingresos aumentarán en 0.9 ECUs, y también aumentarán en 0.9 ECUs los ingresos de la persona con la que estés emparejado. Por tanto, cada ECU asignado al Fondo B aumenta los ingresos conjuntos tuyos y de la otra persona en 1,8 ECUs. Esto también se cumple para cada ECU que la otra persona asigne al fondo $\mathrm{B}$. Por tanto, observa que tus ingresos del fondo $\mathrm{B}$ asi como tus ingresos totales dependen de tu asignación al fondo $\mathrm{B}$ y de la asignación al fondo $\mathrm{B}$ de la persona con la que estés emparejado.

11. En resumen, tus ingresos totales en una ronda se determinas de la forma siguiente:

Ing. individual =

$$
\text { Ing. Fondo } A
$$

50 ECUs - mi asignación al $F^{\circ} B$

Ing. Fondo $\mathrm{B}$

Observa que los ingresos de la otra persona se calculan de forma equivalente.

12. Al final de cada ronda se te informará de la cantidad que haya asignado al fondo B la persona con la que estás emparejado. Además, recibirás información acerca de tus ingresos y los de la otra persona en cada ronda. Esta información relativa a las asignaciones e ingresos de todas las rondas pasadas aparecerá en la pantalla de tu ordenador. 
Por favor, contesta las preguntas siguientes. El experimento sólo continuará después de que todos los participantes hayan contestado correctamente a todas las preguntas.

1. Esta parte del experimento ¿cuántas rondas tiene en total?

2. Primero comerciarás bienes en un mercado. ¿Durante cuántas rondas funcionará el mercado?

3. En el mercado hay vendedores y compradores. Tú eres comprador. En total, ¿cuántos vendedores y compradores habrá en el mercado?

4. En cada ronda los vendedores pueden vender unidades y los compradores pueden comprar unidades. ¿Cuántas unidades puede como máximo vender cada vendedor? ¿Cuántas unidades puede como máximo comprar cada comprador?

5. En cada ronda los participantes que actúan como compradores o vendedores en el mercado son los mismos

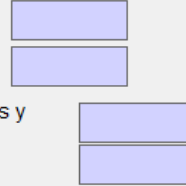

vendedores

compradores

6. Como comprador puedes ganar dinero comprando unidades por debajo de tu valor de comprador. Considera el siguiente ejemplo arbitrario. Para cada unidad que compres tu valor de comprador es 85 ECUs. En una cierta ronda, compras una unidad a un precio de 34 ECUs y otra unidad a 76 ECUs. ¿Cuáles son tus ingresos totales en la ronda?

7. Como comprador puedes ganar dinero comprando unidades por debajo de tu valor de comprador. Considera el siguiente ejemplo arbitrario. Para cada unidad que compres tu valor de comprador es $85 \mathrm{ECUs.}$. En una cierta ronda, no compras ninguna unidad. ¿Cuáles son tus ingresos totales en la ronda?

8. Después de 18 rondas termina la interacción de mercado y serás emparejado con otro participante para otra situación de toma de decisiones, donde tú y el otro participante tendréis que asignar $50 \mathrm{ECUs}$ al fondo $\mathrm{A}$ y al fondo B en cada ronda. ¿Cuántas rondas durará esta otra situación de toma de decisiones?

9. En todas las rondas de esta otra situación de toma de decisiones ¿estarás emparejado con el mismo participante?

$\mathrm{CSI}$

$C$ NO

10. En cada ronda estarás emparejado con:

$C$ un vendedor con el que has interactuado en el mercado

$C$ un vendedor con el que NO has interactuado en el mercado

$\checkmark$ un comprador con el que has interactuado en el mercado

Marcar la respuesta correcta

un comprador con el que NO has interactuado en el mercado

11. En esta otra situación de toma de decisiones, considera la siguiente situación arbitraria en una ronda: Tu asignación al fondo $\mathrm{B}$ es de $50 \mathrm{ECUs}$, la asignación y la asignación al fondo $\mathrm{B}$ de la persona con la que estás emparejada es de 50 ECUs. En esta situación
Tu ingresos serian
Los ingresos de la persona con la que estás emparejada serian

12. En esta otra situación de toma de decisiones, considera la siguiente situación arbitaria en una ronda: Tu asignación al fondo $\mathrm{B}$ es de $0 \mathrm{ECUs}$, la asignación y la asignación al fondo $\mathrm{B}$ de la persona con la que estás emparejada es de 0 ECUs. En esta situación

$$
\begin{aligned}
& \text { Tu ingresos serian } \\
& \text { Los ingresos de la persona con la que estás emparejada serian }
\end{aligned}
$$

13. En esta otra situación de toma de decisiones, considera la siguiente situación arbitaria en una ronda: Tu asignación al fondo $\mathrm{B}$ es de $15 \mathrm{ECUs}$, la asignación y la asignación al fondo B de la persona con la que estás emparejada es de 35 ECUs. En esta situación

$$
\text { Tu ingresos serian }
$$




\section{VENDEDORES}

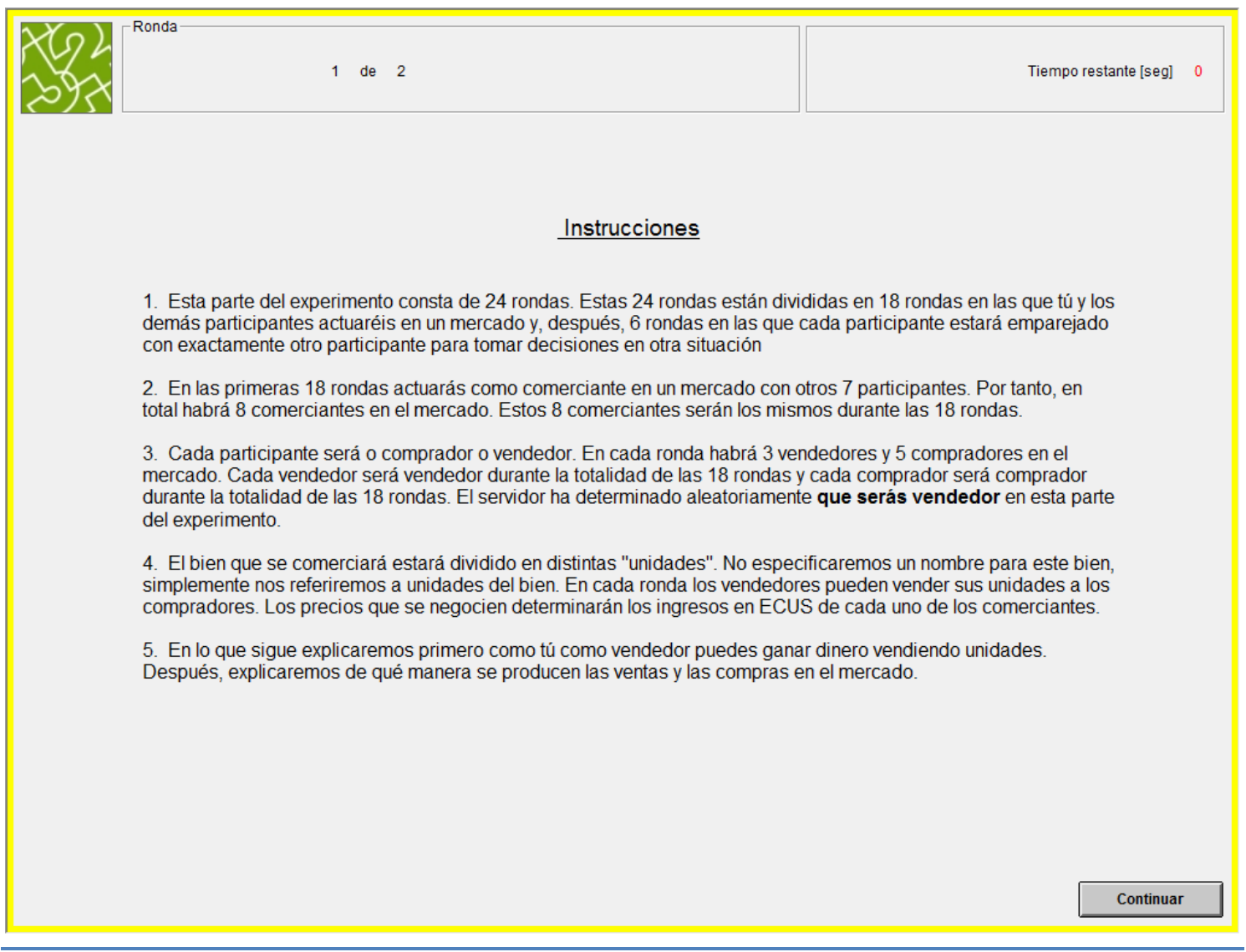

Ronda

Unidades a vender y costes de los vendedores:

En cada ronda, cada vendedor puede vender hasta 2 unidades, pero es libre de no vender ninguna o de vender sólo una. Por cada unidad vendida durante una ronda un vendedor tiene un coste de vendedor de $10 \mathrm{ECUs}$ Por una unidad que un vendedor no venda el vendedor no incurre ningún coste para esa unidad.

Ingresos de un vendedor

Los vendedores ganan dinero vendiendo unidades a precios por encima de sus costes de vendedor. Estas ganancias se computan restando el coste del vendedor del precio de cada unidad. Por tanto,

Ingresos del vendedor de la unidad = precio de venta -10

Si un vendedor no vende ninguna unidad en una ronda, este vendedor no gana ningún ECU en esa ronda

Por cada unidad que un comprador compre el comprador recibe un valor de comprador y puede ganar dinero comprando la unidad a un precio inferior al valor de comprador. En cada ronda, cada comprador puede comprar hasta 2 unidades, pero puede también comprar sólo una unidad o no comprar ninguna. Si un comprador no compra ninguna unidad en una ronda, este comprador no gana ningún ECU en esa ronda.

Los precios a los que vendedores y compradores pueden comerciar son todos los números enteros entre $10 \mathrm{y}$ 95. Es decir, los precios a los que está permitido comerciar son $10,11,12,13,14, \ldots 92,93,94,95$.

6. Cada ronda durará un máximo de 3 minutos. Las unidades que al final de los 3 minutos no se hayan intercambiado se pierden, es decir, no pasan a la ronda siguiente.

7. Los valores de los compradores y los costes de los vendedores son información privada y no serán revelados ni durante ni después del experimento. 
-Ronda

Reglas para hacer transacciones:

En cada ronda valen las siguientes reglas para hacer transacciones:

1. Los compradores hacen ofertas de compra y los vendedores hacen ofertas de venta. Una oferta de un comprador consiste en ofrecer un precio al que comprar. Una oferta de un vendedor consiste en ofrecer un precio al que vender

2. Solamente la oferta de compra más alta y la oferta de venta más baja son los denominados precios pendientes a los que pueden tener lugar las transacciones.

3. El precio de transacción es siempre el precio de la oferta de venta (compra) pendiente. Se produce una transacción si una oferta de compra (venta) pendiente es aceptada por un vendedor (comprador). Para ello hay que seleccionar la oferta pendiente y hacer click en Vender (Comprar).

4. Nuevas ofertas de precios tienen que ser mejoras. Es decir, una nueva oferta de compra (venta) tiene que ser superior (inferior) que el precio de la oferta de compra (venta) pendiente.

5. Si se produce una transacción el mercado se vacia y cualquier precio de oferta de compra o de oferta de venta en el intervalo factible vuelve a ser posible. Observa que los precios de ofertas de compra (de ofertas de venta) tienen que ser iguales o inferiores (superiores) al correspondiente valor del comprador (coste de venta del vendedor).

6. Las unidades del bien se comercian una a una. Es decir, no se pueden ofertar ni comerciar varias unidades a la vez

A continuación se muestra un ejemplo

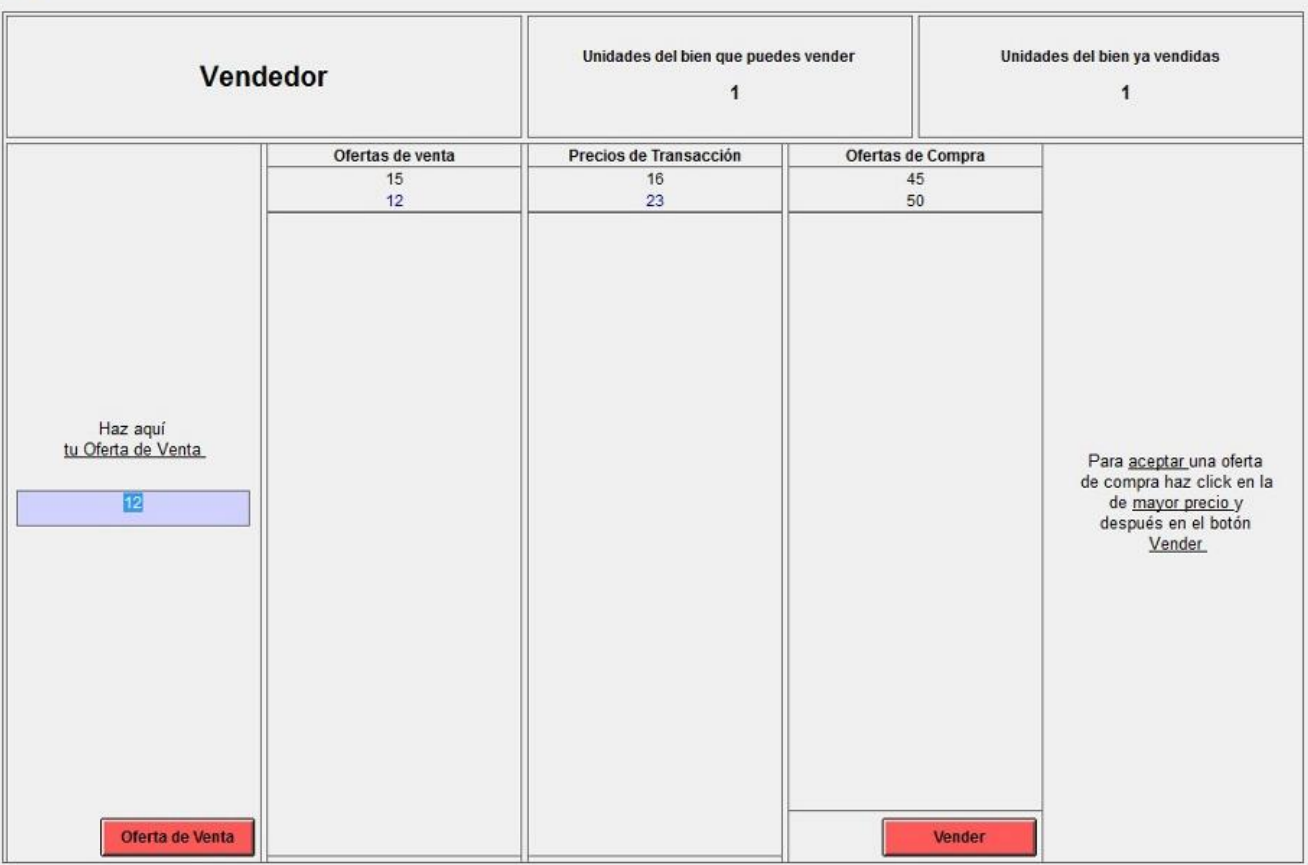


Esta es una pantalla de ejemplo de un vendedor en un mercado en el que se han realizado dos ofertas de venta (columna izquierda), dos transacciones (columna central) y dos ofertas de compra (columna derecha)

En la fila superior, se muestra como este vendedor ya ha vendido una unidad del bien, y por tanto le queda aún otra unidad del bien que puede vender.

\section{Ofertas de venta}

Otro vendedor realizó previamente una oferta de venta de 15. Posteriormente el vendedor ha realizado una oferta de venta 12 (resaltada en azul). El precio pendiente es el de menor precio, en este caso 12.

\section{Precios transacción}

Este vendedor ya ha realizado una transacción (Venta) por un valor de 23 ECUs (valor resaltado en azul). Otros participantes de tu mercado han realizado una transacción por el valor de 16 ECUs.

\section{Ofertas de compra}

Un comprador ha realizado una oferta de compra de 45 ECUs. Posteriormente otro comprador ha realizado una oferta de 50 ECUs. El precio pendiente es 50.

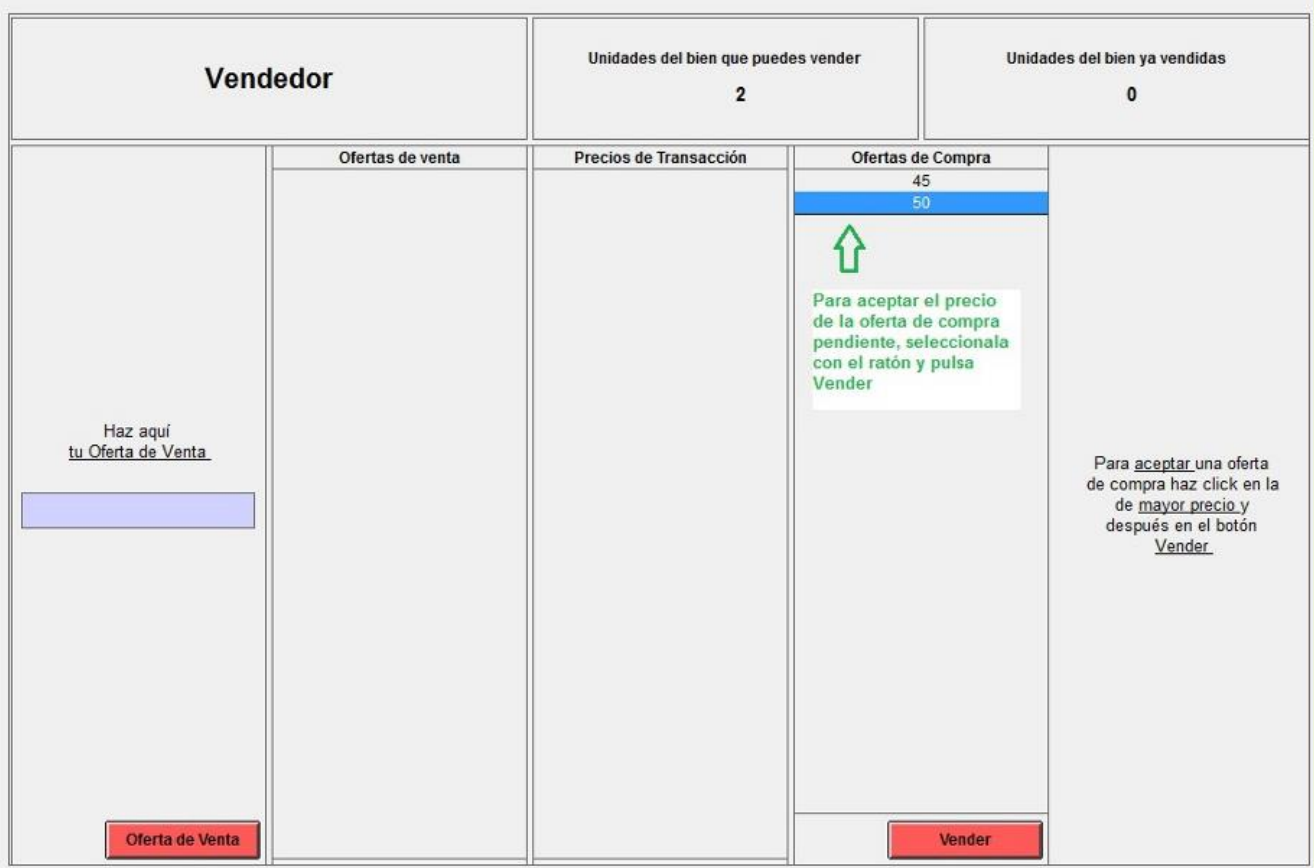

Esta pantalla te recuerda como aceptar la oferta de compra pendiente. 
Este es el final de las instrucciones para el mercado en el que actuarás como comerciante. Este mercado durará 18 rondas. Después de 18 rondas participarás durante otras 6 rondas (las rondas 19 a 24) en otra situación de toma de decisiones. Esto se explicará a continuación.

7. En cada uno de las rondas después del mercado, estarás emparejado con otro participante. Este participante será el mismo durante las 6 rondas. Serás emparejado con otro comprador de otro mercado con el que no has interactuado en el mercado.

8. En cada ronda, cada participante recibe una asignación de 50 ECUs. En cada ronda la decisión a tomar es cuánto asignar a un fondo $\mathrm{A}$ y cuánto a un fondo $\mathrm{B}$. En cada ronda, tendrás que decidir cuantos ECUs depositar en el fondo $\mathrm{B}$ y el resto será asignado automáticamente al fondo $\mathrm{A}$

9. Por cada ECU que asignes al fondo $A$ tus ingresos aumentarán en 1 ECU

10. Por cada ECU que asignes al Fondo B tus ingresos aumentarán en 0.9 ECUs, y también aumentarán en 0.9 ECUs los ingresos de la persona con la que estés emparejado. Por tanto, cada ECU asignado al Fondo B aumenta los ingresos conjuntos tuyos y de la otra persona en 1,8 ECUs. Esto también se cumple para cada ECU que la otra persona asigne al fondo $\mathrm{B}$. Por tanto, observa que tus ingresos del fondo $\mathrm{B}$ asi como tus ingresos totales dependen de tu asignación al fondo $\mathrm{B}$ y de la asignación al fondo $\mathrm{B}$ de la persona con la que estés emparejado.

11. En resumen, tus ingresos totales en una ronda se determinas de la forma siguiente:

Ing. individual =

$$
\text { Ing. Fondo } A
$$

50 ECUs - mi asignación al $F^{\circ} B$

Ing. Fondo $\mathrm{B}$

Observa que los ingresos de la otra persona se calculan de forma equivalente.

12. Al final de cada ronda se te informará de la cantidad que haya asignado al fondo B la persona con la que estás emparejado. Además, recibirás información acerca de tus ingresos y los de la otra persona en cada ronda. Esta información relativa a las asignaciones e ingresos de todas las rondas pasadas aparecerá en la pantalla de tu ordenador. 
Por favor, contesta las preguntas siguientes. El experimento sólo continuará después de que todos los participantes hayan contestado correctamente a todas las preguntas.

1. Esta parte del experimento ¿cuántas rondas tiene en total?

2. Primero comerciarás bienes en un mercado. ¿Durante cuántas rondas funcionará el mercado?

3. En el mercado hay vendedores y compradores. Tú eres vendedor. En total, ¿cuántos vendedores y compradores habrá en el mercado?

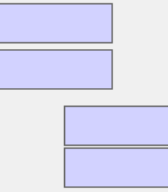

4. En cada ronda los vendedores pueden vender unidades y los compradores pueden comprar unidades. ¿Cuántas unidades puede como máximo vender cada vendedor? ¿Cuántas unidades puede como máximo comprar cada comprador?

5. En cada ronda los participantes que actúan como compradores o vendedores en el mercado son los mismos

6. Como vendedor puedes ganar dinero vendiendo unidades por encima de tu coste de venta. Considera el siguiente ejemplo arbitrario. Por cada unidad que vendas tu coste de venta es 10 ECUs. En una cierta ronda vendes una unidad a 34 ECUs y otra unidad a 76 ECUs. ¿Cuáles son tus ingresos totales en la ronda?

7. Como vendedor puedes ganar dinero vendiendo unidades por encima de tu coste de venta. Considera el siguiente ejemplo arbitrario. Por cada unidad que vendas tu coste de venta es $10 \mathrm{ECUs}$. En una cierta ronda no vendes ninguna unidad. ¿Cuáles son tus ingresos totales en la ronda?

8. Después de 18 rondas termina la interacción de mercado y serás emparejado con otro participante para otra situación de toma de decisiones, donde tú y el otro participante tendréis que asignar $50 \mathrm{ECUs}$ al fondo A y al fondo B en cada ronda. ¿Cuántas rondas durará esta otra situación de toma de decisiones?

9. En todas las rondas de esta otra situación de toma de decisiones ¿estarás emparejado con el mismo participante?

$$
\text { C SI }
$$$$
C \text { NO }
$$

10. En cada ronda estarás emparejado con

$C$ un vendedor con el que has interactuado en el mercado un vendedor con el que NO has interactuado en el mercado $C$ un comprador con el que has interactuado en el mercado

Marcar la respuesta correcta

11. En esta otra situación de toma de decisiones, considera la siguiente situación arbitraria en una ronda: Tu asignación al fondo $\mathrm{B}$ es de $50 \mathrm{ECUs}$, la asignación y la asignación al fondo $\mathrm{B}$ de la persona con la que estás emparejada es de 50 ECUs. En esta situación
Tu ingresos serian
Los ingresos de la persona con la que estás emparejada serian

12. En esta otra situación de toma de decisiones, considera la siguiente situación arbitaria en una ronda: Tu asignación al fondo $\mathrm{B}$ es de $0 \mathrm{ECUs}$, la asignación y la asignación al fondo $\mathrm{B}$ de la persona con la que estás emparejada es de $0 \mathrm{ECUs}$. En esta situación

$$
\begin{aligned}
& \text { Tu ingresos serian } \\
& \text { Los ingresos de la persona con la que estás emparejada serian }
\end{aligned}
$$

13. En esta otra situación de toma de decisiones, considera la siguiente situación arbitaria en una ronda: Tu asignación al fondo $\mathrm{B}$ es de $15 \mathrm{ECUs}$, la asignación y la asignación al fondo B de la persona con la que estás emparejada es de 35 ECUs. En esta situación

$$
\text { Tu ingresos serían }
$$




\section{VENDEDORES Y COMPRADORES}

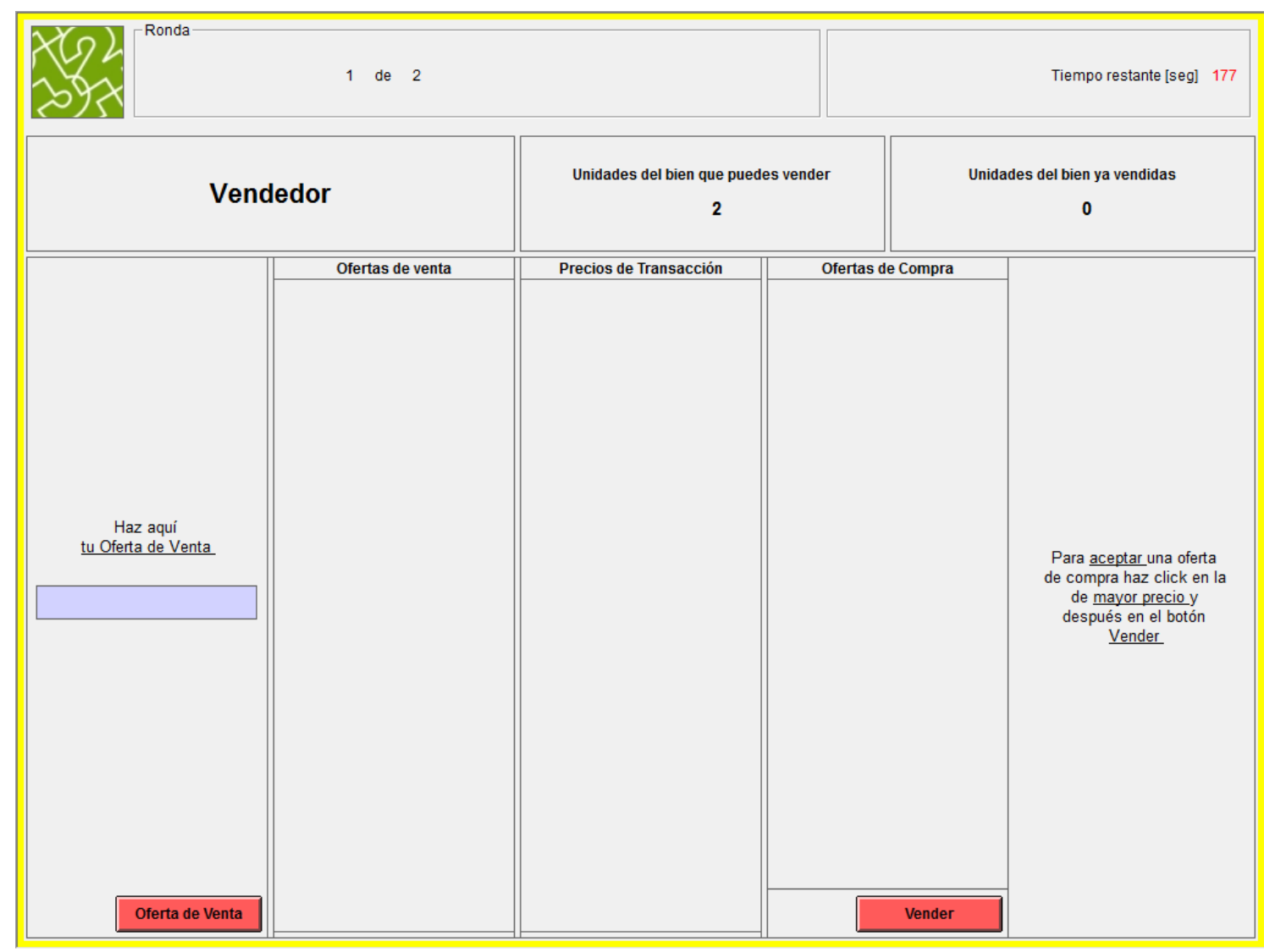

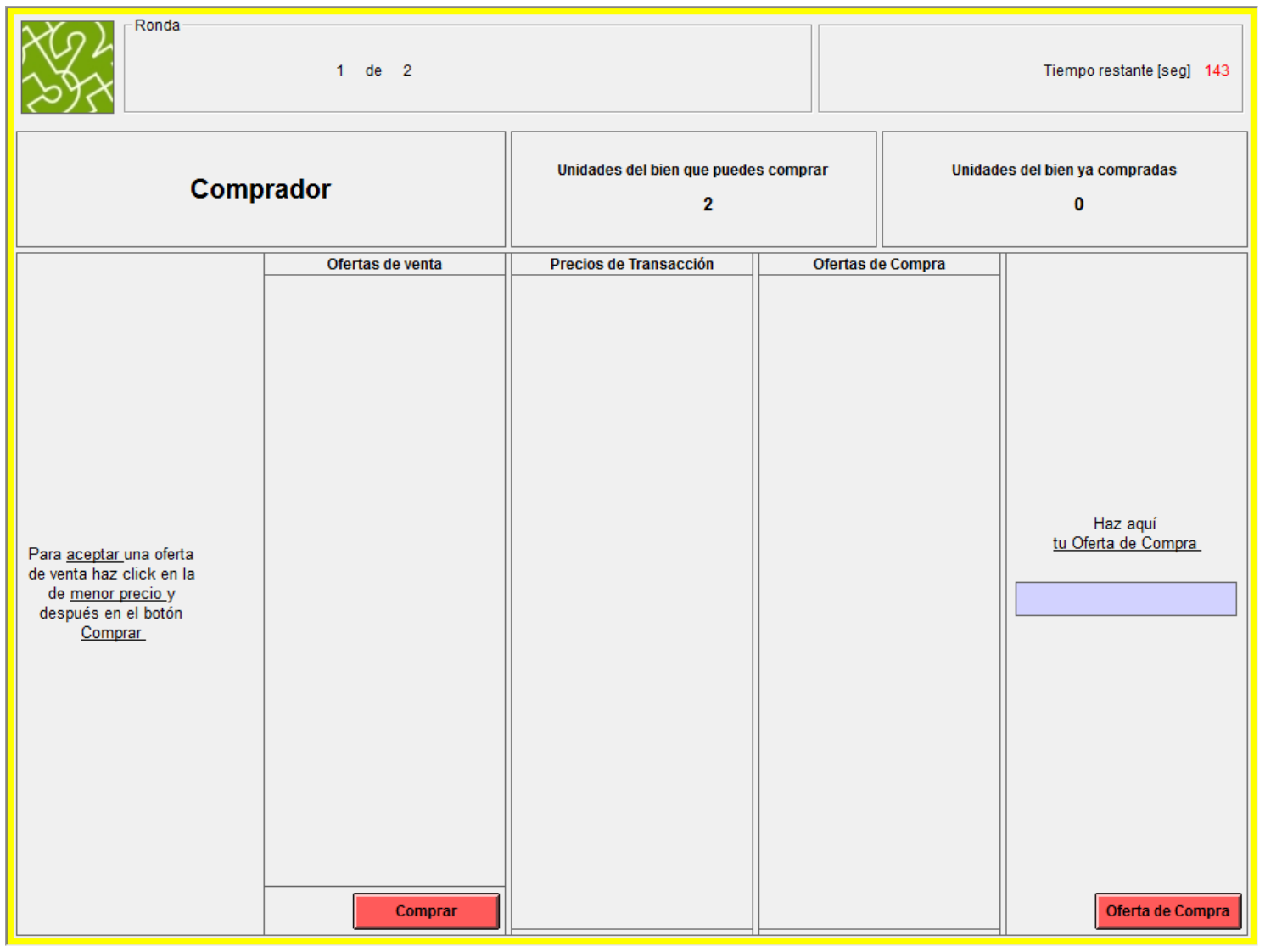


Se han hecho todas las transacciones posibles en el mercado

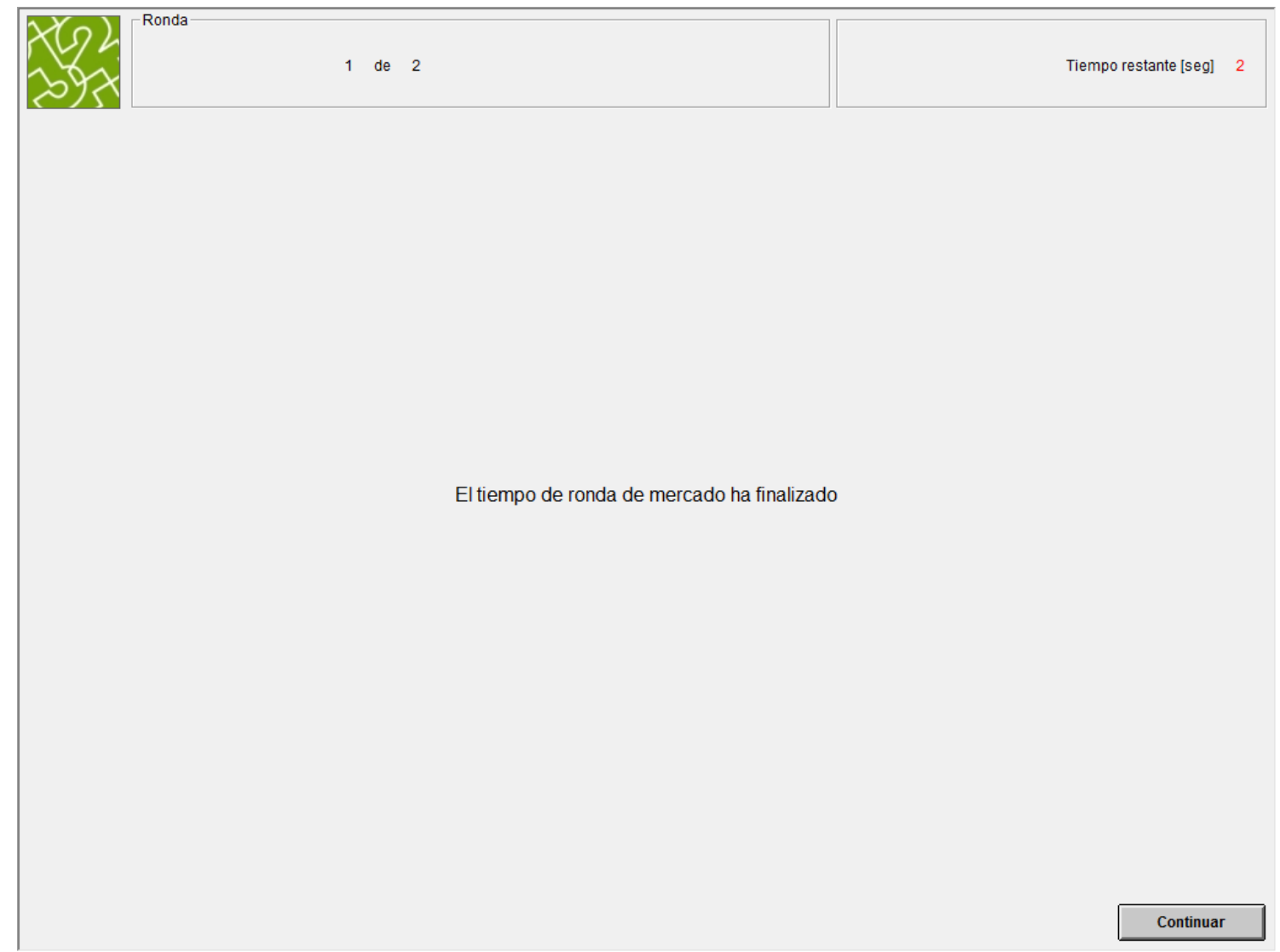

(esta pantalla dura 3 segundos) 
Unidades compradas: 1

Ingreso en esta ronda: $\mathbf{9 0 . 0}$

Ingreso acumulado: $\quad 90.0$

\begin{tabular}{|c|c|}
\hline $\mathbf{N}^{0}$ de la Unidad & Precio \\
\hline 1 & 10.0 \\
\hline
\end{tabular}

Esta ha sido la última ronda del Mercado. Ahora participarás durante otras 6 rondas (rondas 19 a 24) en la otra situación de toma de decisiones mencionada en las instrucciones. 


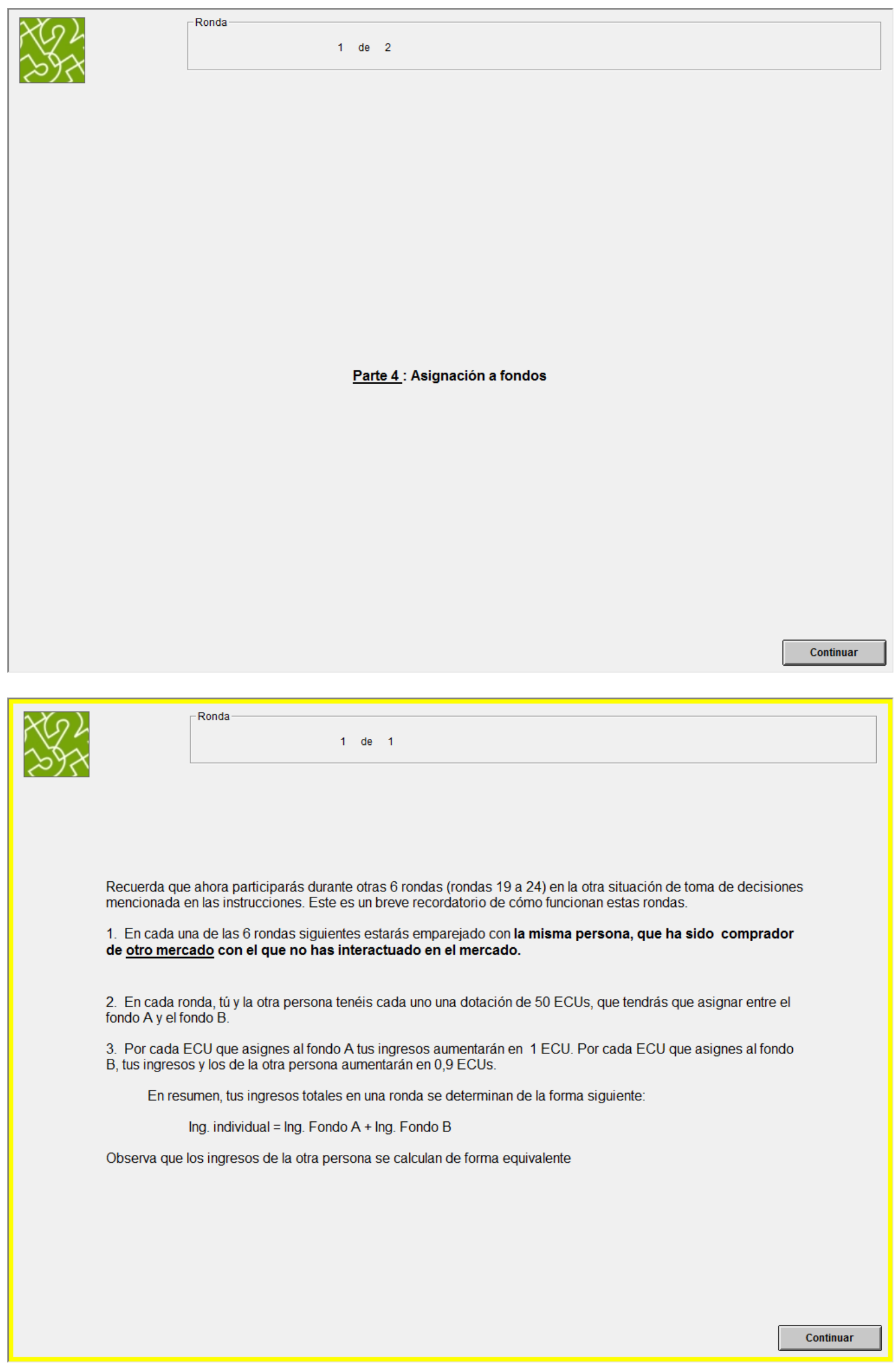

Recuerda que ahora participarás durante otras 6 rondas (rondas 19 a 24) en la otra situación de toma de decisiones mencionada en las instrucciones. Este es un breve recordatorio de cómo funcionan estas rondas

1. En cada una de las 6 rondas siguientes estarás emparejado con la misma persona, que ha sido comprador de otro mercado con el que no has interactuado en el mercado.

2. En cada ronda, tú y la otra persona tenéis cada uno una dotación de 50 ECUs, que tendrás que asignar entre e 

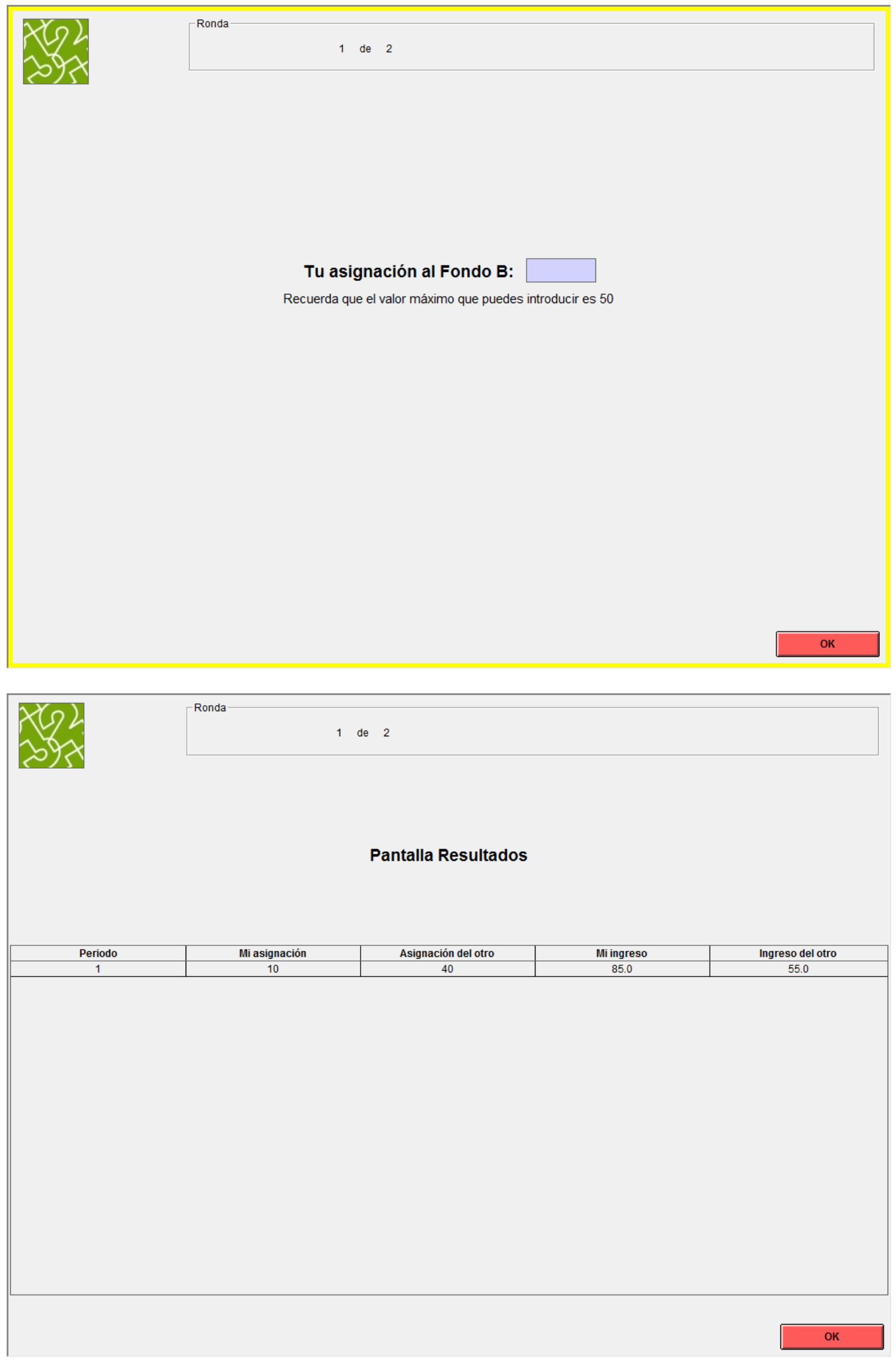
Parte 5

Continuar

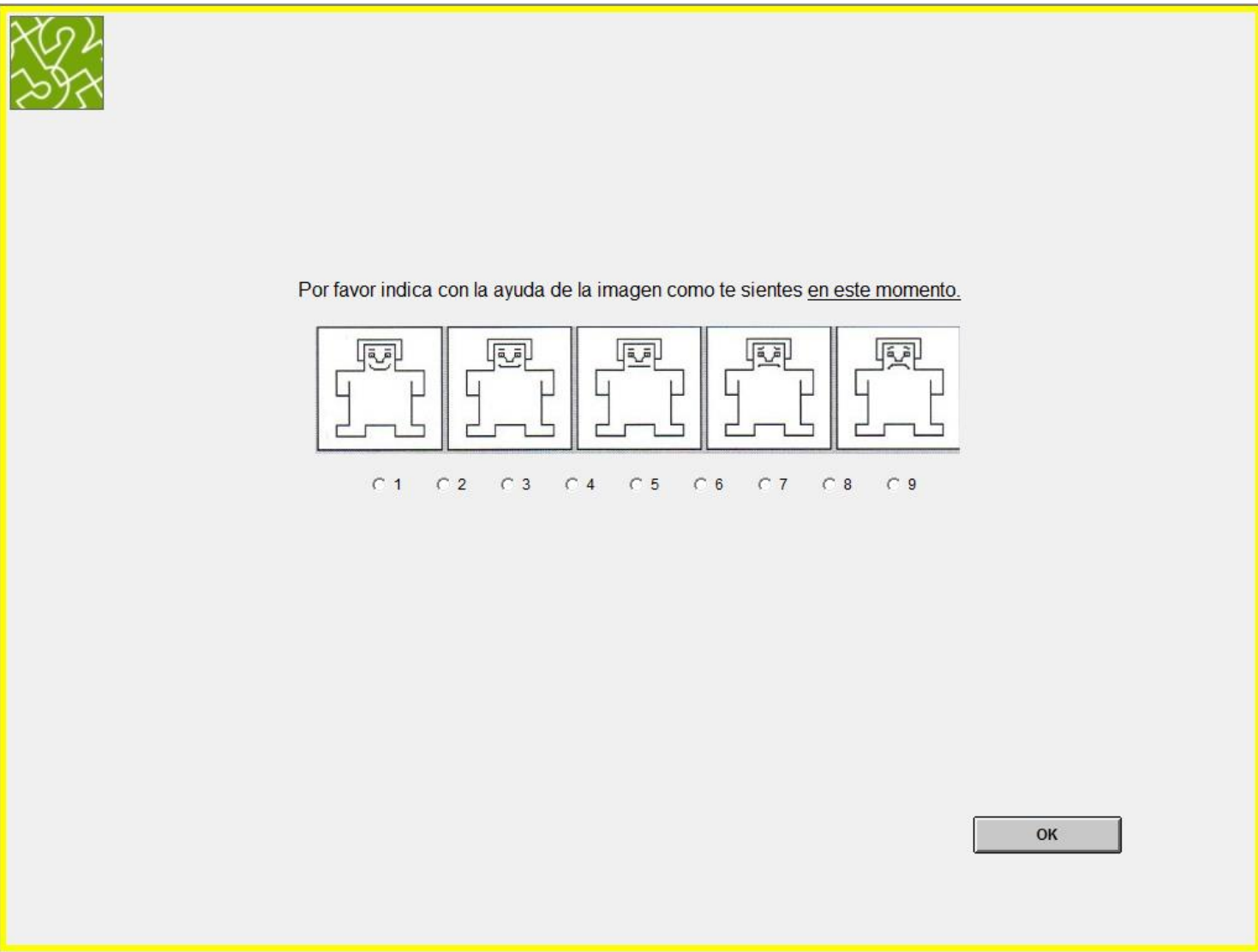


Parte 6: Círculo.

Decisión

Con la ayuda del ratón, selecciona un punto de la circunferencia. Recuerda que puedes cambiar de decisión tantas veces como desees. Cuando hayas terminado pulsa OK.

NOTA: Recuerda que no vas a interactuar con el participante al que le asignas ECUs en ninguna otra parte del experimento, y que no es posible la reciprocidad en el emparejamiento.

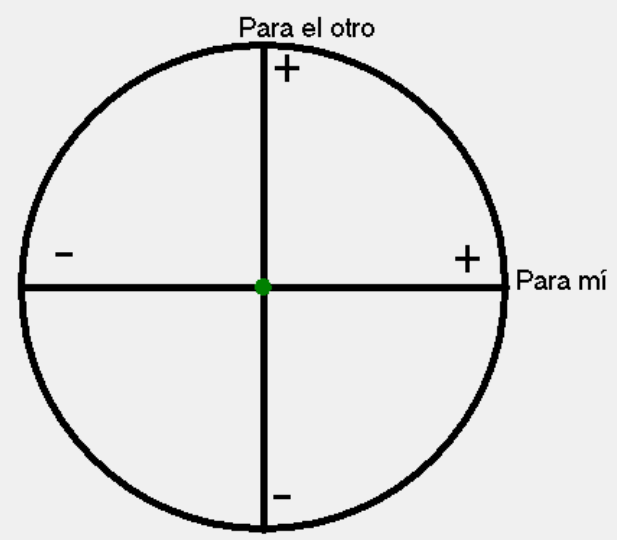

Para mí: $0.00 \mathrm{ECU}$

Para el otro: $0.00 \mathrm{ECU}$ 


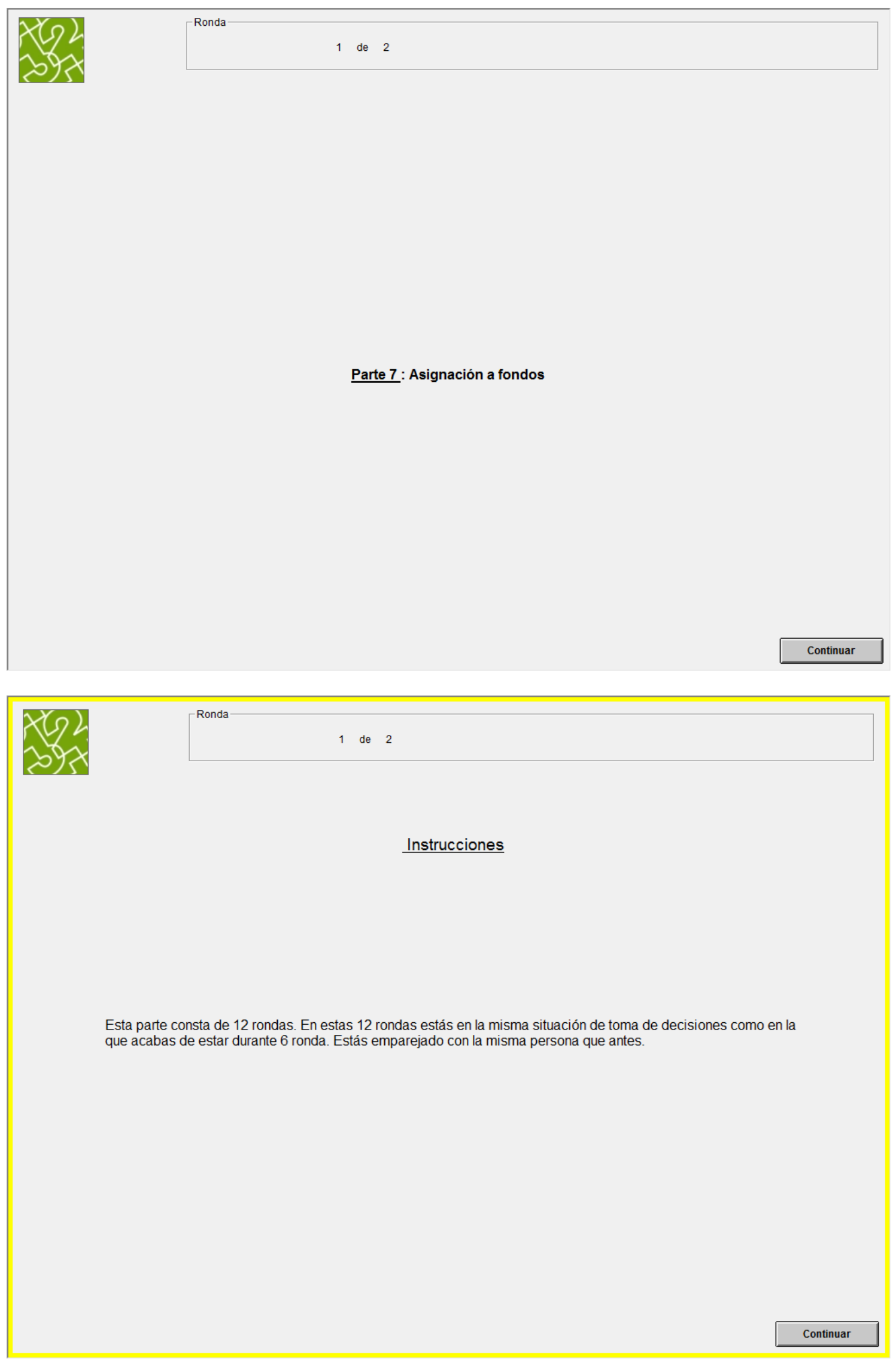



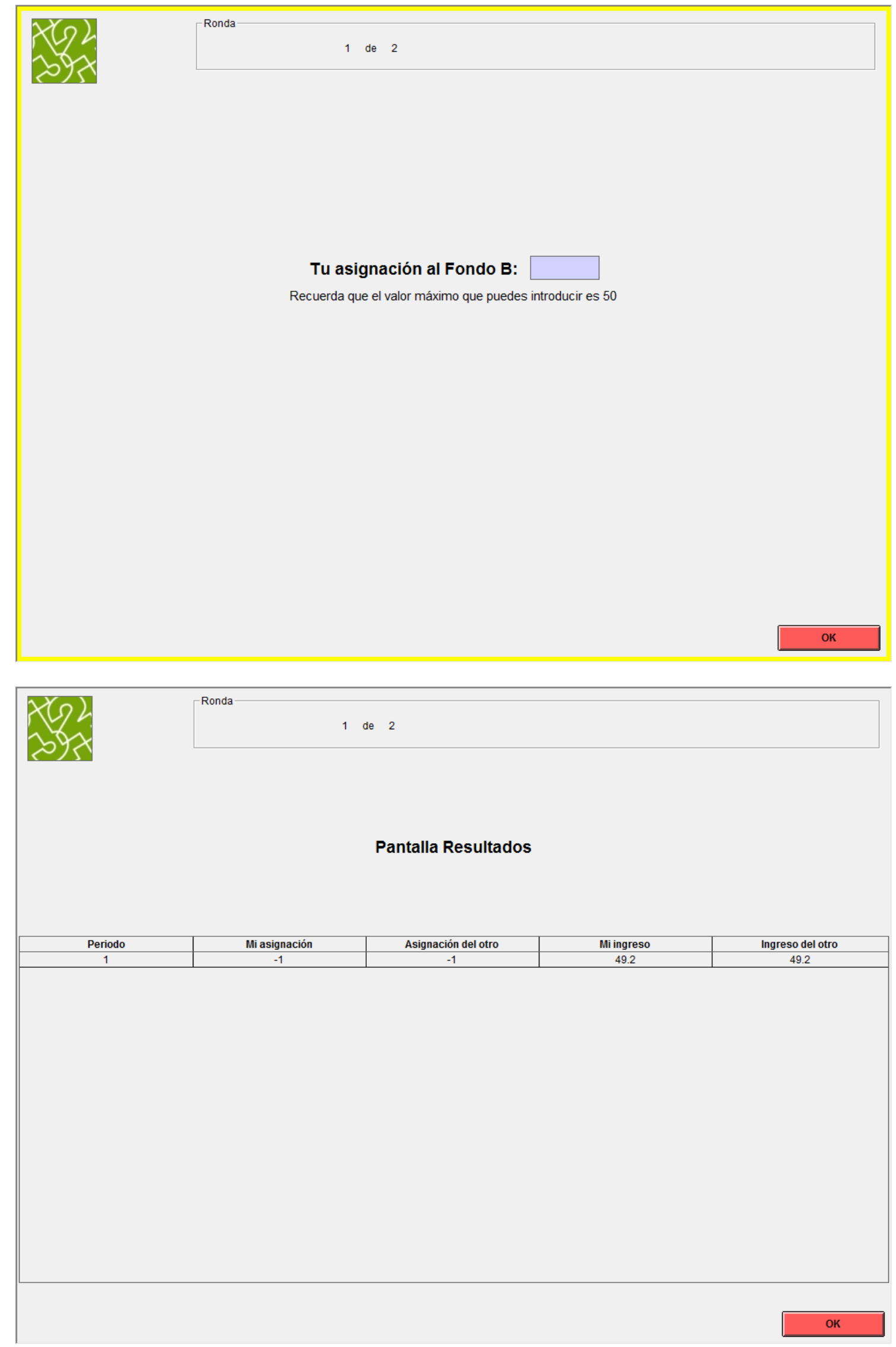
Resultados Finales

Parte 2: Círculo

Parte 3: Mercado

Has seleccionado: $0.00 \mathrm{ECUs}$

Tu pareja ha seleccionado para ti: $0.00 \mathrm{ECU}$

198.00 ECUs

Parte 4: Asignaciones a fondos

Parte 6: Círculo 2

Parte 7: Asignaciones a fondos

\begin{tabular}{|c|}
\hline $\begin{array}{c}\text { Has seleccionado: } 0.00 \mathrm{ECUs} \\
\text { Tu pareja ha seleccionado para ti: } 0.00 \mathrm{ECUs}\end{array}$ \\
\hline $198.00 \mathrm{ECUs}$ \\
\hline $98.40 \mathrm{ECUs}$ \\
\hline Has seleccionado: $0.00 \mathrm{ECUs}$ \\
Tu pareja ha seleccionado para ti: $0.00 \mathrm{ECUs}$ \\
\hline \\
$98.40 \mathrm{ECUs}$ \\
\hline
\end{tabular}

Total : $394.8 \mathrm{ECUs}$

\section{Introduce tus datos personales, por favor.}

Género

¿Qué edad tienes?

Nacionalidad

Qué titulación estudias?

¿En qué curso estás?

¿Cuántos, de los participantes en el experimento son amigos tuyos?

¿En cuántos experimentos has participado previamente?

¿Fueron claras las instrucciones?

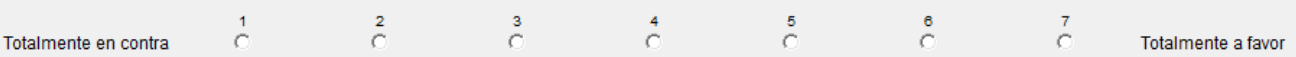




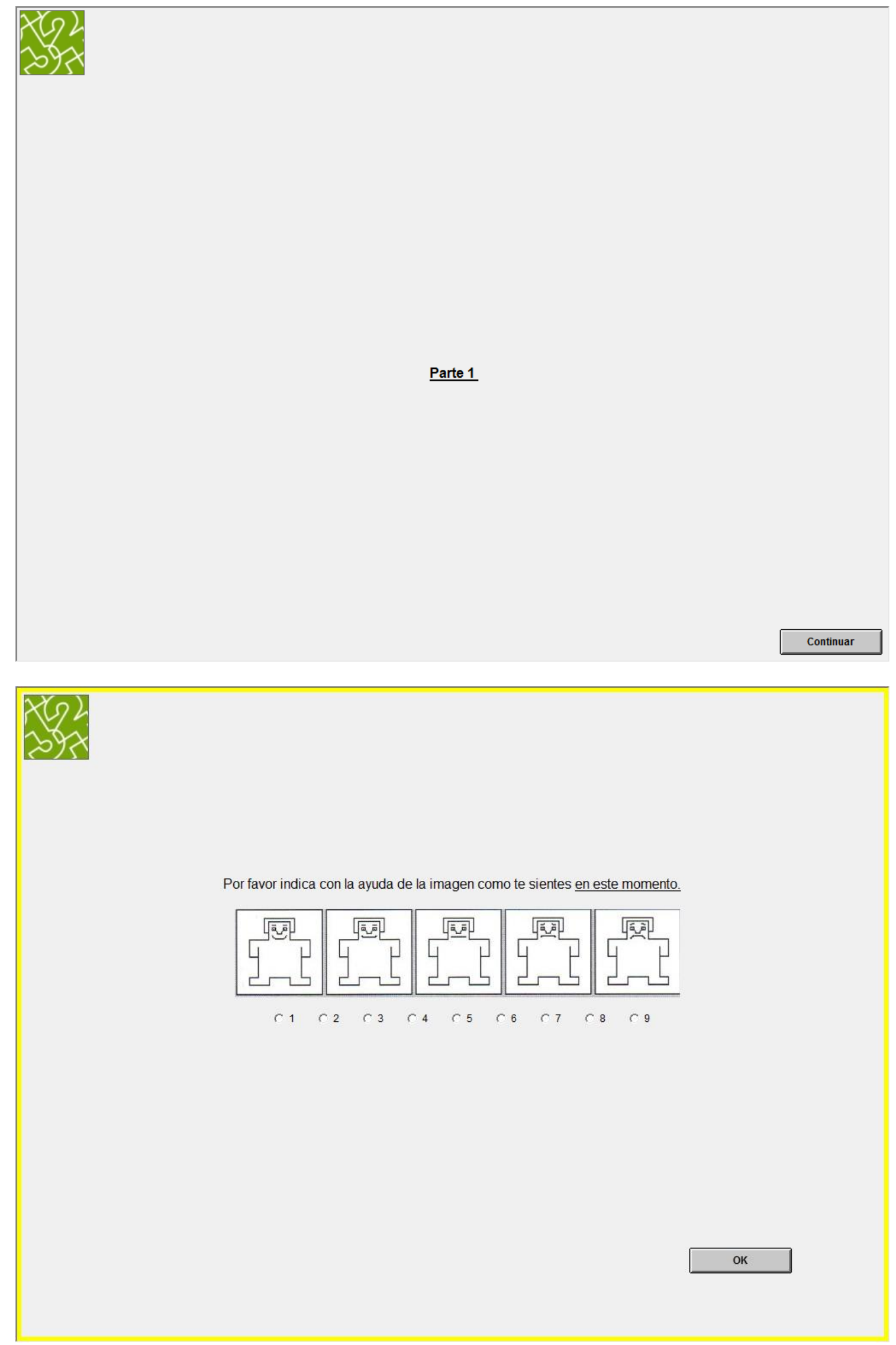


Parte 2: Círculo.

Ronda de Prueba

\section{Instrucciones}

1. En esta parte del experimento vas a tomar una única decisión. Tu decisión consiste en elegir una distribución de ECUs entre tú y otro participante. El otro participante lo seleccionará el servidor de manera aleatoria y no vas a interactuar con él/ella en ninguna otra parte del experimento. Además, este emparejamiento no es recíproco, esto es, el participante al que le asignas una cantidad de ECUs con tu decisión no es el mismo que el que te asigna una cantidad de ECUs a ti.

2. En la pantalla verás una circunferencia. Seleccionando un punto de esta circunferencia asignas una cantidad de ECUs para ti y una para el otro participante. Cada punto de la circunferencia corresponde a una cantidad que será sumada (o restada) de tus ingresos y a una cantidad que será sumada (o restada) de los ingresos del participante con el que estás conectado. Tomando esta decisión puedes incrementar (o reducir) tus ingresos y los del otro participante. Las distribuciones factibles están comprendidas entre + 200 ECUs y -200 ECUs.

3. Con la ayuda del ratón podrás hacer "click" en cualquier punto de la circunferencia. Al hacer eso se dibujará una flecha que unirá el centro de la circunferencia con el punto que hayas seleccionado. Además, debajo de la circunferencia se te mostrarán las cantidades exactas de ECUs que has seleccionado para ti y para el otro participante con el que estás conectado

4. Tus ingresos en esta parte se determinarán por tu decisión (la cantidad de ECUs que te asignas a ti mismo), y por los ECUs que te asigne el participante que está conectado contigo. Recuerda que este no es el mismo al que tu asignas ECUs con tu decisión. Concretamente tus ingresos en esta parte serán la suma de esas dos cantidades.

NOTA: Las cantidades pueden ser positivas y negativas. Puede darse el caso de que la cantidad resultante de la suma de las dos cantidades sea negativa.

5. Podrás cambiar tu decisión hasta que estés satisfecho con tu decisión clickando en distintos puntos. Cuandos estés satisfecho de tu decisión, confirmala pulsando el botón OK. 

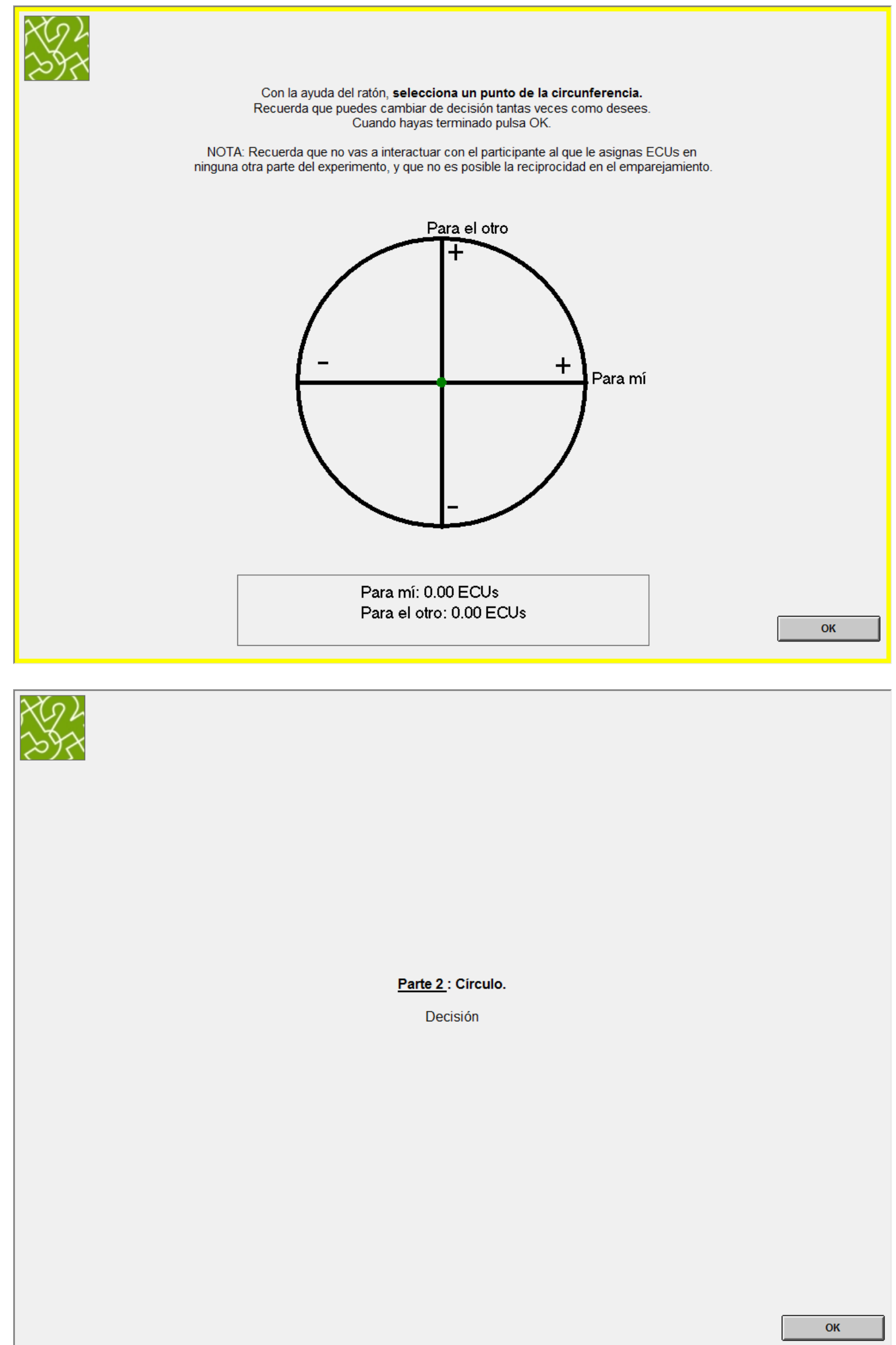


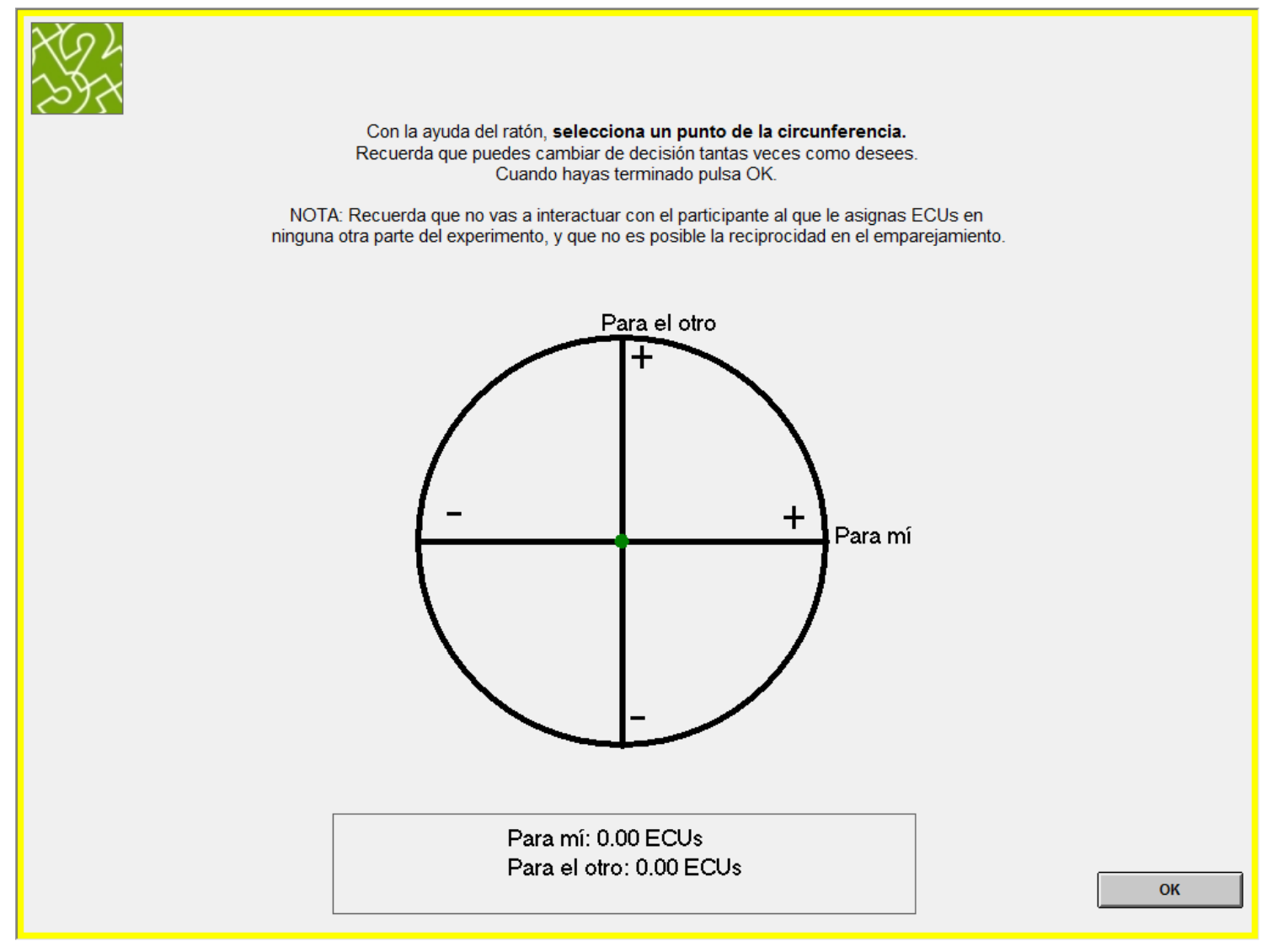

\begin{tabular}{|lllll}
\hline Ronda- & Te 2 & Tiempo restante [seg] & 0 \\
\hline
\end{tabular}

Parte 3: Mercados 


\section{COMPRADORES}

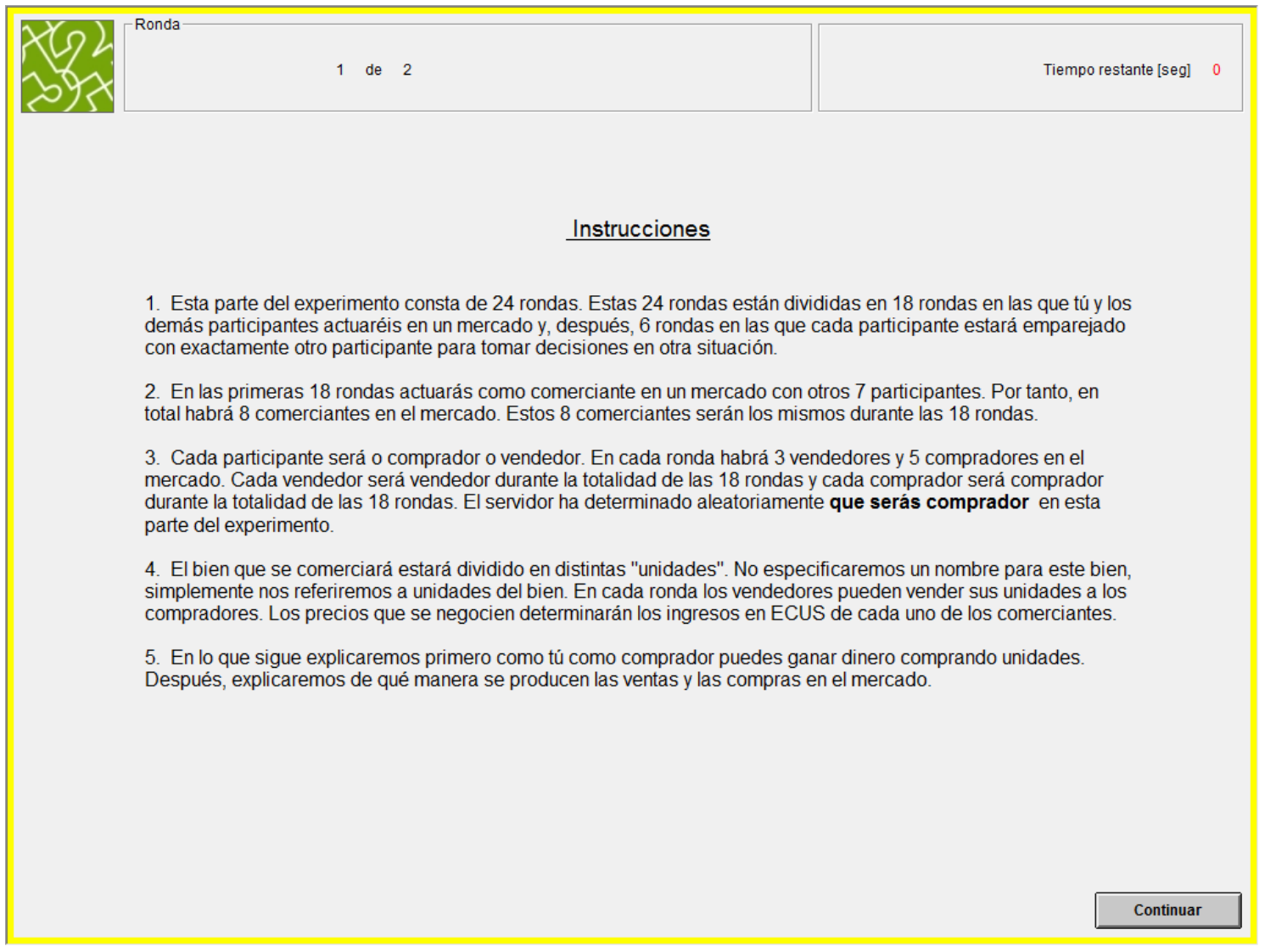

\section{-Ronda}

Unidades a comprar y valores de los compradores:

En cada ronda, cada comprador puede comprar hasta 2 unidades, pero es libre de no comprar ninguna o de comprar sólo una. Por cada unidad comprada durante una ronda un comprador recibe un valor de comprador de 100 ECUs. Por una unidad que un comprador no compre el comprador no recibe ningún valor de comprador para esa unidad.

Ingresos de un comprador

Los compradores ganan dinero comprando unidades a precios por debajo de sus valores de comprador. Estas ganancias se computan restando el precio de cada unidad de su valor de comprador. Por tanto,

Ingresos del comprador de la unidad = 100 - precio de compra de la unidad

Si un comprador no compra ninguna unidad en una ronda, este comprador no gana ningún ECU en esa ronda.

Por cada unidad que un vendedor venda el vendedor tiene que pagar un coste de venta y puede ganar dinero vendiendo la unidad a un precio superior al coste de venta. En cada ronda cada vendedor puede vender hasta 2 unidades, pero puede también vender sólo una unidad o no vender ninguna. Si un vendedor no vende ninguna unidad en una ronda, este vendedor no gana ningún ECU en esa ronda.

Los precios a los que vendedores y compradores pueden comerciar son todos los números enteros entre $10 \mathrm{y}$ 95. Es decir, los precios a los que está permitido comerciar son $10,11,12,13,14, \ldots .92,93,94,95$.

6. Cada ronda durará un máximo de 3 minutos. Las unidades que al final de los 3 minutos no se hayan intercambiado se pierden, es decir, no pasan a la ronda siguiente.

7. Los valores de los compradores y los costes de los vendedores son información privada y no serán revelados ni durante ni después del experimento. 


\section{Reglas para hacer transacciones:}

En cada ronda valen las siguientes reglas para hacer transacciones:

1. Los compradores hacen ofertas de compra y los vendedores hacen ofertas de venta. Una oferta de un comprador consiste en ofrecer un precio al que comprar. Una oferta de un vendedor consiste en ofrecer un precio al que vender.

2. Solamente la oferta de compra más alta y la oferta de venta más baja son los denominados precios pendientes a los que pueden tener lugar las transacciones.

3. El precio de transacción es siempre el precio de la oferta de compra (venta) pendiente. Se produce una transacción si una oferta de compra (venta) pendiente es aceptada por un vendedor (comprador). Para ello hay que seleccionar la oferta pendiente y hacer click en Comprar (Vender)

4. Nuevas ofertas de precios tienen que ser mejoras. Es decir, una nueva oferta de compra (venta) tiene que ser superior (inferior) al precio de la oferta de compra (venta) pendiente.

5. Si se produce una transacción el mercado se vacia y cualquier precio de oferta de compra o de oferta de venta en el intervalo factible vuelve a ser posible. Observa que los precios de ofertas de compra (de ofertas de venta) tienen que ser iguales o inferiores (superiores) al correspondiente valor del comprador (coste de venta de vendedor).

6. Las unidades del bien se comercian una a una. Es decir, no se pueden ofertar ni comerciar varias unidades a la vez

A continuación se muestra un ejemplo.

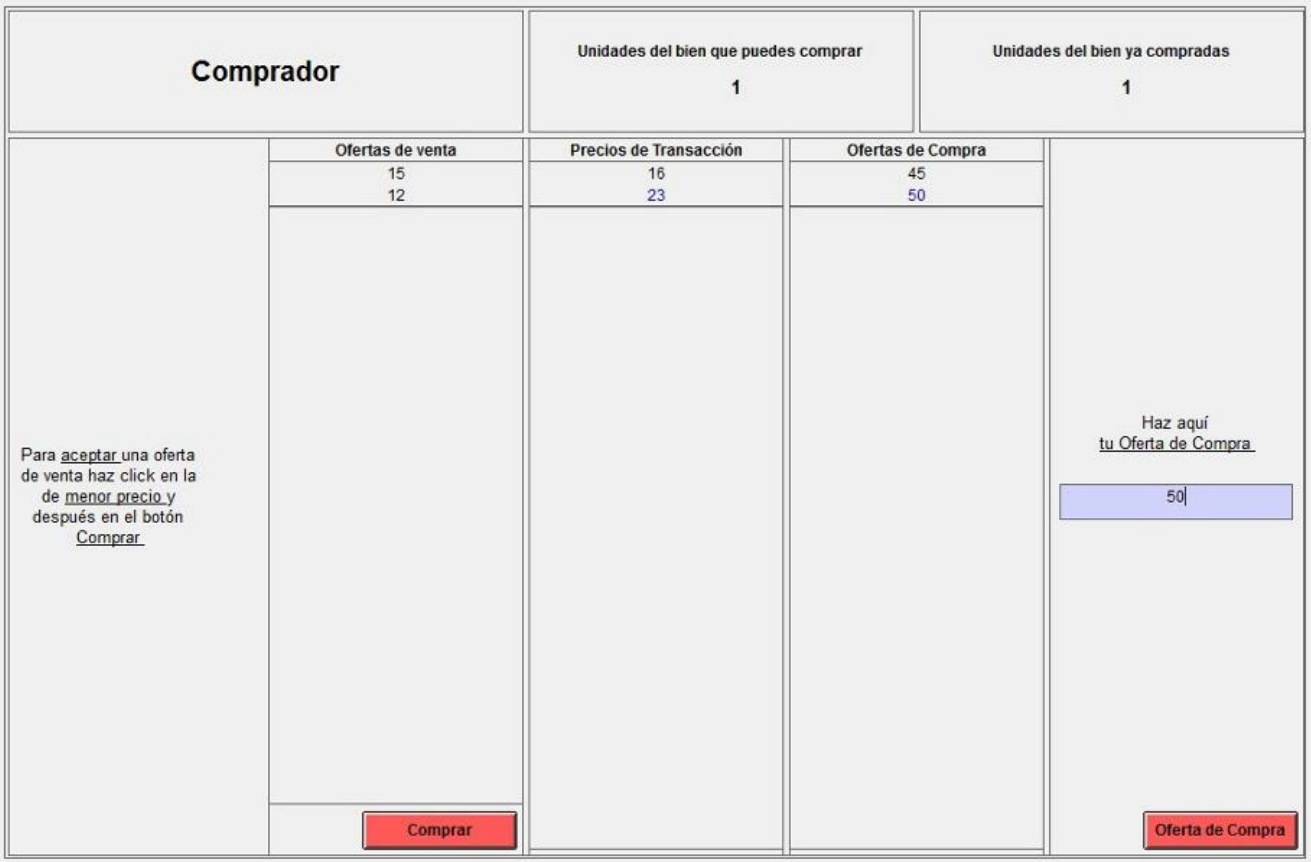

Pulsa a Continuar para ver la explicación. 
Esta es una pantalla de ejemplo de un comprador en un mercado en el que se han realizado dos ofertas de venta (columna izquierda), dos transacciones (columna central) y dos ofertas de compra (columna derecha)

En la fila superior, se muestra como este comprador ya ha comprado una unidad del bien, y por tanto le queda aún otra unidad del bien que puede comprar

\section{Ofertas de venta}

Un vendedor ha realizado una oferta de venta de 15. Posteriormente otro vendedor (o el mismo que realizó la anterior) ha realizado una oferta de venta 12. El precio pendiente es el de menor precio, en este caso 12

\section{Precios transacción}

Este comprador ya ha realizado una transacción (Compra) por un valor de 23 ECUs (valor resaltado en azul). Otros participantes de tu mercado han realizado una transacción por el valor de 16 ECUs

\section{Ofertas de compra}

Otro comprador ha realizado una oferta de compra de 45 ECUs. Posteriormente el comprador del ejemplo ha realizado una oferta de $50 \mathrm{ECUs}$ (resaltada en azul). El precio pendiente es 50 .

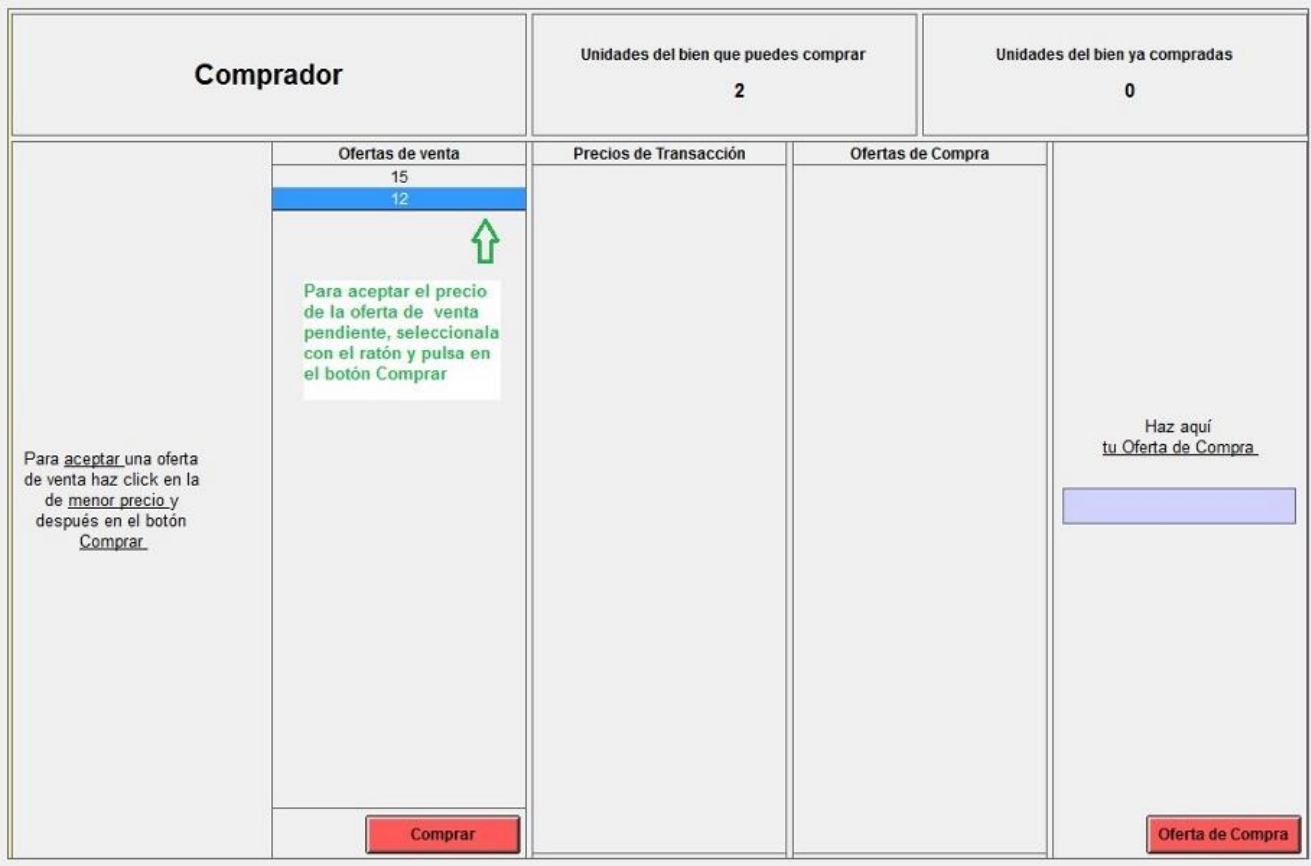

Esta pantalla te recuerda como aceptar la oferta de venta pendiente. 
Este es el final de las instrucciones para el mercado en el que actuarás como comerciante. Este mercado durará 18 rondas. Después de 18 rondas participarás durante otras 6 rondas (las rondas 19 a 24) en otra situación de toma de decisiones. Esto se explicará a continuación.

7. En cada uno de las rondas después del mercado, estarás emparejado con otro participante. Este participante será el mismo durante las 6 rondas. Serás emparejado con otro comprador con el que también has interactuado en el mercado.

8. En cada ronda, cada participante recibe una asignación de 50 ECUs. En cada ronda la decisión a tomar es cuánto asignar a un fondo $\mathrm{A}$ y cuánto $\mathrm{a}$ un fondo $\mathrm{B}$. En cada ronda, tendrás que decidir cuantos ECUs depositar en el fondo $B$ y el resto será asignado automáticamente al fondo $A$.

9. Por cada ECU que asignes al fondo A tus ingresos aumentarán en $1 \mathrm{ECU}$

10. Por cada ECU que asignes al Fondo $B$ tus ingresos aumentarán en 0.9 ECUs, y también aumentarán en 0.9 ECUs los ingresos de la persona con la que estés emparejado. Por tanto, cada ECU asignado al Fondo B aumenta los ingresos conjuntos tuyos y de la otra persona en 1,8 ECUs. Esto también se cumple para cada ECU que la otra persona asigne al fondo B. Por tanto, observa que tus ingresos del fondo $\mathrm{B}$ asi como tus ingresos totales dependen de tu asignación al fondo $\mathrm{B}$ y de la asignación al fondo $\mathrm{B}$ de la persona con la que estés emparejado.

11. En resumen, tus ingresos totales en una ronda se determinas de la forma siguiente:

Ing. individual $=$

Ing. Fondo A

Ing. Fondo $B$

$$
50 \text { ECUs - mi asignación al } F^{\circ} B+\left(0.9 \times F^{\circ} B \text { mio }\right)+\left(0.9 \times F^{\circ} B \text { del otro }\right)
$$

Observa que los ingresos de la otra persona se calculan de forma equivalente

12. Al final de cada ronda se te informará de la cantidad que haya asignado al fondo $B$ la persona con la que estás emparejado. Además, recibirás información acerca de tus ingresos y los de la otra persona en cada ronda. Esta información relativa a las asignaciones e ingresos de todas las rondas pasadas aparecerá en la pantalla de tu ordenador. 
Por favor, contesta las preguntas siguientes. El experimento sólo continuará después de que todos los participantes hayan contestado correctamente a todas las preguntas.

1. Esta parte del experimento ¿cuántas rondas tiene en total?

2. Primero comerciarás bienes en un mercado. ¿Durante cuántas rondas funcionará el mercado?

3. En el mercado hay vendedores y compradores. Tú eres comprador. En total, ¿cuántos vendedores y compradores habrá en el mercado?

4. En cada ronda los vendedores pueden vender unidades y los compradores pueden comprar unidades.

$$
\text { ¿Cuántas unidades puede como máximo vender cada vendedor? }
$$

¿Cuántas unidades puede como máximo comprar cada comprador?

5. En cada ronda los participantes que actúan como compradores o vendedores en el mercado son los mismos

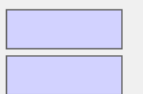

6. Como comprador puedes ganar dinero comprando unidades por debajo de tu valor de comprador. Considera el siguiente ejemplo arbitrario. Para cada unidad que compres tu valor de comprador es $85 \mathrm{ECUs}$. En una cierta ronda, compras una unidad a un precio de 34 ECUs y otra unidad a 76 ECUs. ¿Cuáles son tus ingresos totales en la ronda?

7. Como comprador puedes ganar dinero comprando unidades por debajo de tu valor de comprador. Considera el siguiente ejemplo arbitrario. Para cada unidad que compres tu valor de comprador es 85 ECUs. En una cierta ronda, no compras ninguna unidad. ¿Cuáles son tus ingresos totales en la ronda?

\section{-Ronda}

8. Después de 18 rondas termina la interacción de mercado y serás emparejado con otro participante para otra situación de toma de decisiones, donde tú y el otro participante tendréis que asignar $50 \mathrm{ECUs}$ al fondo $\mathrm{A}$ y al fondo $\mathrm{B}$ en cada ronda. ¿Cuántas rondas durará esta otra situación de toma de decisiones?

9. En todas las rondas de esta otra situación de toma de decisiones ¿estarás emparejado con el mismo participante? C NO

10. En cada ronda estarás emparejado con:

$\checkmark$ un vendedor con el que has interactuado en el mercado $C$ un vendedor con el que NO has interactuado en el mercado

$C$ un comprador con el que has interactuado en el mercado

Marcar la respuesta correcta

$\checkmark$ un comprador con el que NO has interactuado en el mercado

11. En esta otra situación de toma de decisiones, considera la siguiente situación arbitraria en una ronda: Tu asignación al fondo $\mathrm{B}$ es de 50 ECUs, la asignación y la asignación al fondo B de la persona con la que estás emparejada es de 50 ECUs. En esta situación

$$
\begin{aligned}
& \text { Tu ingresos serian } \\
& \text { Los ingresos de la persona con la que estás emparejada serian }
\end{aligned}
$$

12. En esta otra situación de toma de decisiones, considera la siguiente situación arbitaria en una ronda: Tu asignación al fondo $\mathrm{B}$ es de 0 ECUs, la asignación y la asignación al fondo $\mathrm{B}$ de la persona con la que estás emparejada es de 0 ECUs. En esta situación

$$
\begin{aligned}
& \text { Tu ingresos serian } \\
& \text { Los ingresos de la persona con la que estás emparejada serían }
\end{aligned}
$$

13. En esta otra situación de toma de decisiones, considera la siguiente situación arbitaria en una ronda: Tu asignación al fondo $\mathrm{B}$ es de $15 \mathrm{ECUs}$, la asignación y la asignación al fondo B de la persona con la que estás emparejada es de 35 ECUs. En esta situación

$$
\text { Tu ingresos serian }
$$




\section{VENDEDORES}

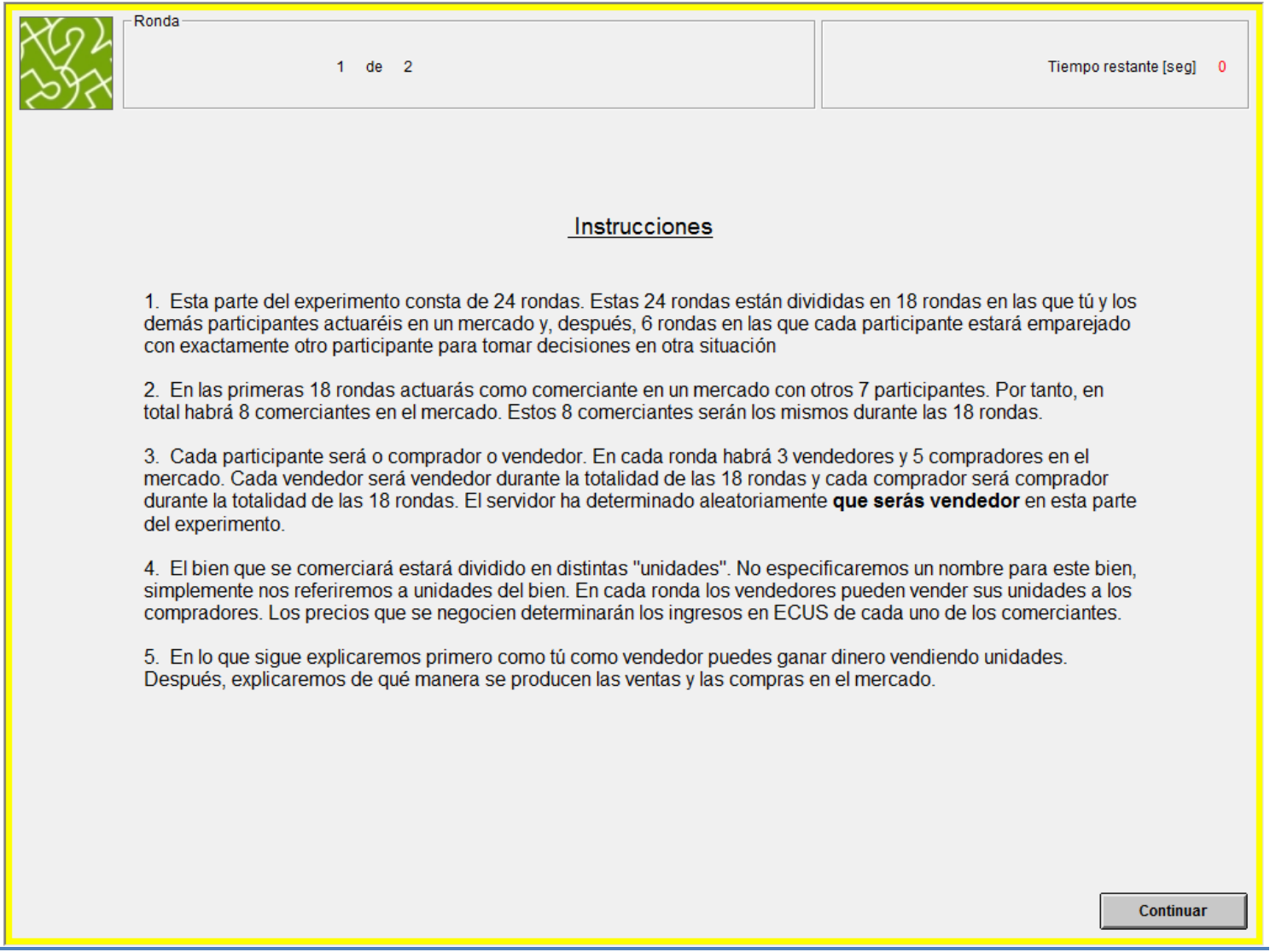

Ronda

Unidades a vender y costes de los vendedores:

En cada ronda, cada vendedor puede vender hasta 2 unidades, pero es libre de no vender ninguna o de vender sólo una. Por cada unidad vendida durante una ronda un vendedor tiene un coste de vendedor de $10 \mathrm{ECUs}$ Por una unidad que un vendedor no venda el vendedor no incurre ningún coste para esa unidad.

Ingresos de un vendedo

Los vendedores ganan dinero vendiendo unidades a precios por encima de sus costes de vendedor. Estas ganancias se computan restando el coste del vendedor del precio de cada unidad. Por tanto,

Ingresos del vendedor de la unidad = precio de venta -10

Si un vendedor no vende ninguna unidad en una ronda, este vendedor no gana ningún ECU en esa ronda.

Por cada unidad que un comprador compre el comprador recibe un valor de comprador y puede ganar dinero comprando la unidad a un precio inferior al valor de comprador. En cada ronda, cada comprador puede comprar hasta 2 unidades, pero puede también comprar sólo una unidad o no comprar ninguna. Si un comprador no compra ninguna unidad en una ronda, este comprador no gana ningún ECU en esa ronda

Los precios a los que vendedores y compradores pueden comerciar son todos los números enteros entre $10 \mathrm{y}$ 95. Es decir, los precios a los que está permitido comerciar son $10,11,12,13,14, \ldots 92,93,94,95$.

6. Cada ronda durará un máximo de 3 minutos. Las unidades que al final de los 3 minutos no se hayan intercambiado se pierden, es decir, no pasan a la ronda siguiente.

7. Los valores de los compradores y los costes de los vendedores son información privada y no serán revelados ni durante ni después del experimento. 


\section{Reglas para hacer transacciones:}

En cada ronda valen las siguientes reglas para hacer transacciones:

1. Los compradores hacen ofertas de compra y los vendedores hacen ofertas de venta. Una oferta de un comprador consiste en ofrecer un precio al que comprar. Una oferta de un vendedor consiste en ofrecer un precio al que vender.

2. Solamente la oferta de compra más alta y la oferta de venta más baja son los denominados precios pendientes a los que pueden tener lugar las transacciones.

3. El precio de transacción es siempre el precio de la oferta de venta (compra) pendiente. Se produce una transacción si una oferta de compra (venta) pendiente es aceptada por un vendedor (comprador). Para ello hay que seleccionar la oferta pendiente y hacer click en Vender (Comprar)

4. Nuevas ofertas de precios tienen que ser mejoras. Es decir, una nueva oferta de compra (venta) tiene que ser superior (inferior) que el precio de la oferta de compra (venta) pendiente.

5. Si se produce una transacción el mercado se vacia y cualquier precio de oferta de compra o de oferta de venta en el intervalo factible vuelve a ser posible. Observa que los precios de ofertas de compra (de ofertas de venta) tienen que ser iguales o inferiores (superiores) al correspondiente valor del comprador (coste de venta de vendedor).

6. Las unidades del bien se comercian una a una. Es decir, no se pueden ofertar ni comerciar varias unidades a la vez

A continuación se muestra un ejemplo.

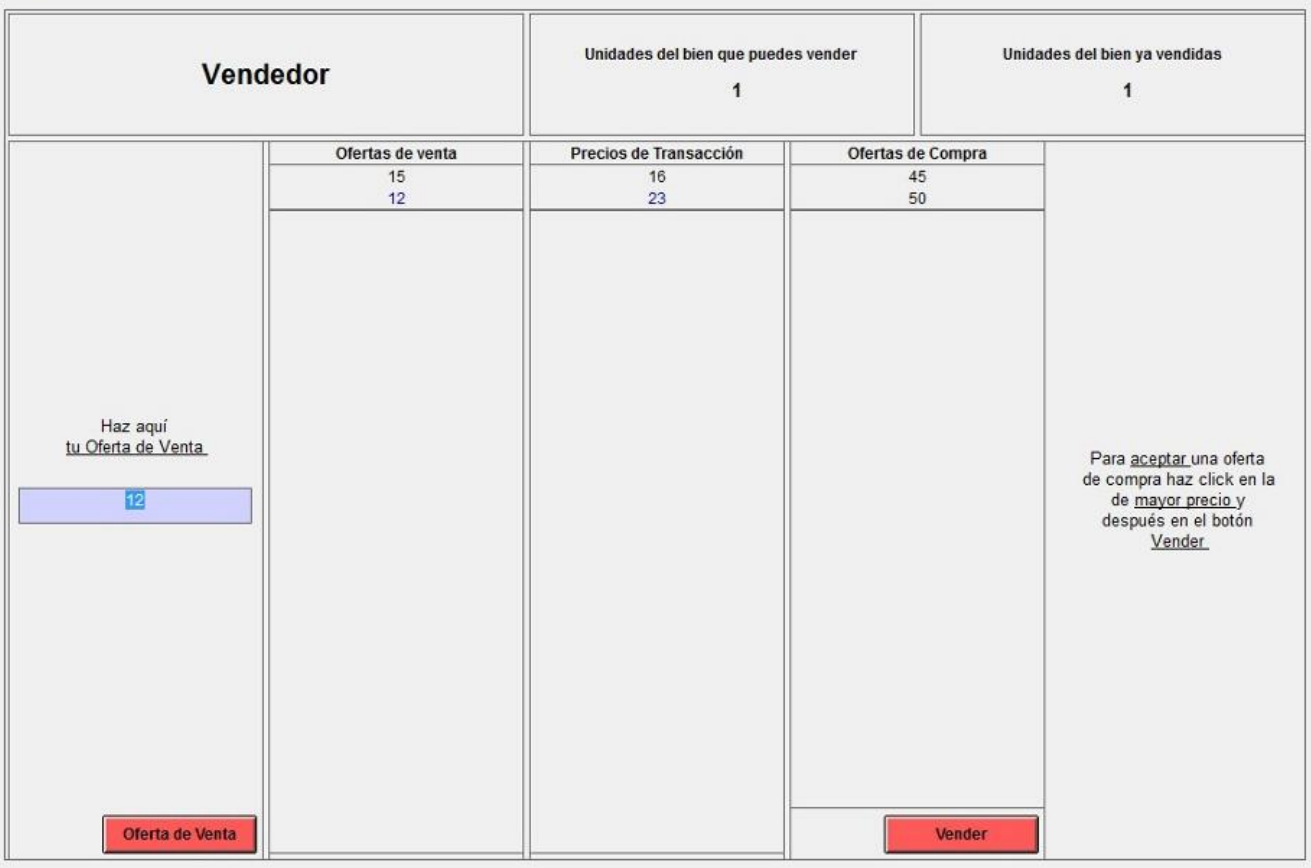

Pulsa a Continuar para ver la explicación. 
Esta es una pantalla de ejemplo de un vendedor en un mercado en el que se han realizado dos ofertas de venta (columna izquierda), dos transacciones (columna central) y dos ofertas de compra (columna derecha).

En la fila superior, se muestra como este vendedor ya ha vendido una unidad del bien, y por tanto le queda aún otra unidad del bien que puede vender

\section{Ofertas de venta}

Otro vendedor realizó previamente una oferta de venta de 15. Posteriormente el vendedor ha realizado una oferta de venta 12 (resaltada en azul). El precio pendiente es el de menor precio, en este caso 12.

\section{Precios transacción}

Este vendedor ya ha realizado una transacción (Venta) por un valor de 23 ECUs (valor resaltado en azul). Otros participantes de tu mercado han realizado una transacción por el valor de 16 ECUs.

\section{Ofertas de compra}

Un comprador ha realizado una oferta de compra de 45 ECUs. Posteriormente otro comprador ha realizado una oferta de 50 ECUs. El precio pendiente es 50

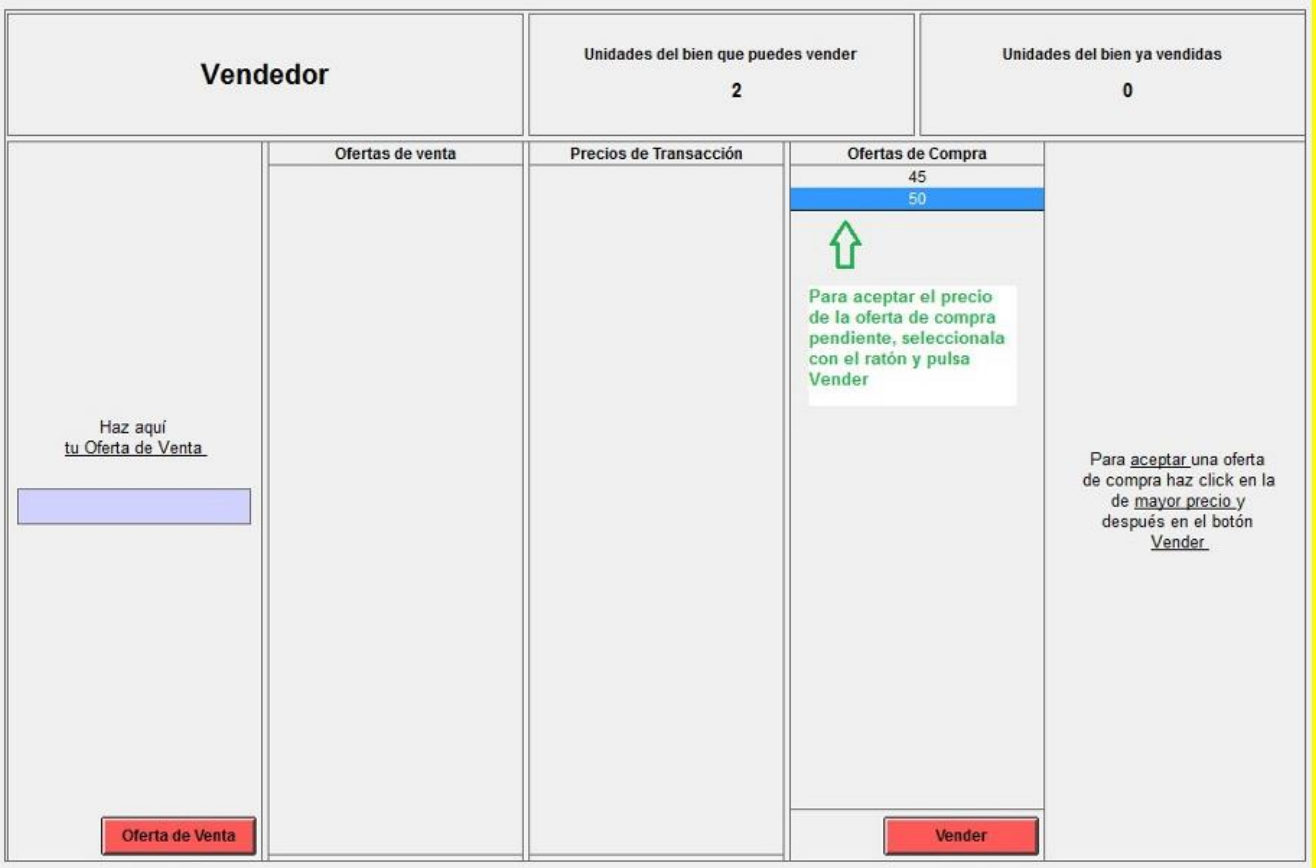

Esta pantalla te recuerda como aceptar la oferta de compra pendiente. 
Este es el final de las instrucciones para el mercado en el que actuarás como comerciante. Este mercado durará 18 rondas. Después de 18 rondas participarás durante otras 6 rondas (las rondas 19 a 24) en otra situación de toma de decisiones. Esto se explicará a continuación.

7. En cada uno de las rondas después del mercado, estarás emparejado con otro participante. Este participante será el mismo durante las 6 rondas. Serás emparejado con otro comprador con el que también has interactuado en el mercado.

8. En cada ronda, cada participante recibe una asignación de 50 ECUs. En cada ronda la decisión a tomar es cuánto asignar a un fondo $\mathrm{A}$ y cuánto $\mathrm{a}$ un fondo $\mathrm{B}$. En cada ronda, tendrás que decidir cuantos ECUs depositar en el fondo $B$ y el resto será asignado automáticamente al fondo $A$.

9. Por cada ECU que asignes al fondo A tus ingresos aumentarán en $1 \mathrm{ECU}$

10. Por cada ECU que asignes al Fondo $B$ tus ingresos aumentarán en 0.9 ECUs, y también aumentarán en 0.9 ECUs los ingresos de la persona con la que estés emparejado. Por tanto, cada ECU asignado al Fondo B aumenta los ingresos conjuntos tuyos y de la otra persona en 1,8 ECUs. Esto también se cumple para cada ECU que la otra persona asigne al fondo B. Por tanto, observa que tus ingresos del fondo $\mathrm{B}$ asi como tus ingresos totales dependen de tu asignación al fondo $\mathrm{B}$ y de la asignación al fondo $\mathrm{B}$ de la persona con la que estés emparejado.

11. En resumen, tus ingresos totales en una ronda se determinas de la forma siguiente:

Ing. individual $=$

Ing. Fondo A

Ing. Fondo $B$

$$
50 \text { ECUs - mi asignación al } F^{\circ} B+\left(0.9 \times F^{\circ} B \text { mio }\right)+\left(0.9 \times F^{\circ} B \text { del otro }\right)
$$

Observa que los ingresos de la otra persona se calculan de forma equivalente

12. Al final de cada ronda se te informará de la cantidad que haya asignado al fondo $B$ la persona con la que estás emparejado. Además, recibirás información acerca de tus ingresos y los de la otra persona en cada ronda. Esta información relativa a las asignaciones e ingresos de todas las rondas pasadas aparecerá en la pantalla de tu ordenador. 
Por favor, contesta las preguntas siguientes. El experimento sólo continuará después de que todos los participantes hayan contestado correctamente a todas las preguntas.

1. Esta parte del experimento ¿cuántas rondas tiene en total?

2. Primero comerciarás bienes en un mercado. ¿Durante cuántas rondas funcionará el mercado?

3. En el mercado hay vendedores y compradores. Tú eres vendedor. En total, ¿cuántos vendedores y compradores habrá en el mercado?

4. En cada ronda los vendedores pueden vender unidades y los compradores pueden comprar unidades.

$$
\text { ¿Cuántas unidades puede como máximo vender cada vendedor? }
$$

¿Cuántas unidades puede como máximo comprar cada comprador?

5. En cada ronda los participantes que actúan como compradores o vendedores en el mercado son los mismos

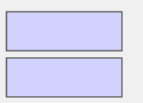

6. Como vendedor puedes ganar dinero vendiendo unidades por encima de tu coste de venta. Considera el siguiente ejemplo arbitrario. Por cada unidad que vendas tu coste de venta es 10 ECUs. En una cierta ronda vendes una unidad a 34 ECUs y otra unidad a 76 ECUs. ¿Cuáles son tus ingresos totales en la ronda?

7. Como vendedor puedes ganar dinero vendiendo unidades por encima de tu coste de venta. Considera el siguiente ejemplo arbitrario. Por cada unidad que vendas tu coste de venta es 10 ECUs. En una cierta ronda no vendes ninguna unidad. ¿Cuáles son tus ingresos totales en la ronda?

\section{-Ronda}

8. Después de 18 rondas termina la interacción de mercado y serás emparejado con otro participante para otra situación de toma de decisiones, donde tú y el otro participante tendréis que asignar $50 \mathrm{ECUs}$ al fondo $\mathrm{A}$ y al fondo $\mathrm{B}$ en cada ronda. ¿Cuántas rondas durará esta otra situación de toma de decisiones?

9. En todas las rondas de esta otra situación de toma de decisiones ¿estarás emparejado con el mismo participante? C NO

10. En cada ronda estarás emparejado con:

$\checkmark$ un vendedor con el que has interactuado en el mercado $C$ un vendedor con el que NO has interactuado en el mercado

$C$ un comprador con el que has interactuado en el mercado

Marcar la respuesta correcta

$\checkmark$ un comprador con el que NO has interactuado en el mercado

11. En esta otra situación de toma de decisiones, considera la siguiente situación arbitraria en una ronda: Tu asignación al fondo $\mathrm{B}$ es de 50 ECUs, la asignación y la asignación al fondo B de la persona con la que estás emparejada es de 50 ECUs. En esta situación

$$
\begin{aligned}
& \text { Tu ingresos serian } \\
& \text { Los ingresos de la persona con la que estás emparejada serian }
\end{aligned}
$$

12. En esta otra situación de toma de decisiones, considera la siguiente situación arbitaria en una ronda: Tu asignación al fondo $\mathrm{B}$ es de 0 ECUs, la asignación y la asignación al fondo $\mathrm{B}$ de la persona con la que estás emparejada es de 0 ECUs. En esta situación

$$
\begin{aligned}
& \text { Tu ingresos serian } \\
& \text { Los ingresos de la persona con la que estás emparejada serian }
\end{aligned}
$$

13. En esta otra situación de toma de decisiones, considera la siguiente situación arbitaria en una ronda: Tu asignación al fondo $\mathrm{B}$ es de $15 \mathrm{ECUs}$, la asignación y la asignación al fondo B de la persona con la que estás emparejada es de 35 ECUs. En esta situación

$$
\text { Tu ingresos serian }
$$




\section{VENDEDORES Y COMPRADORES}

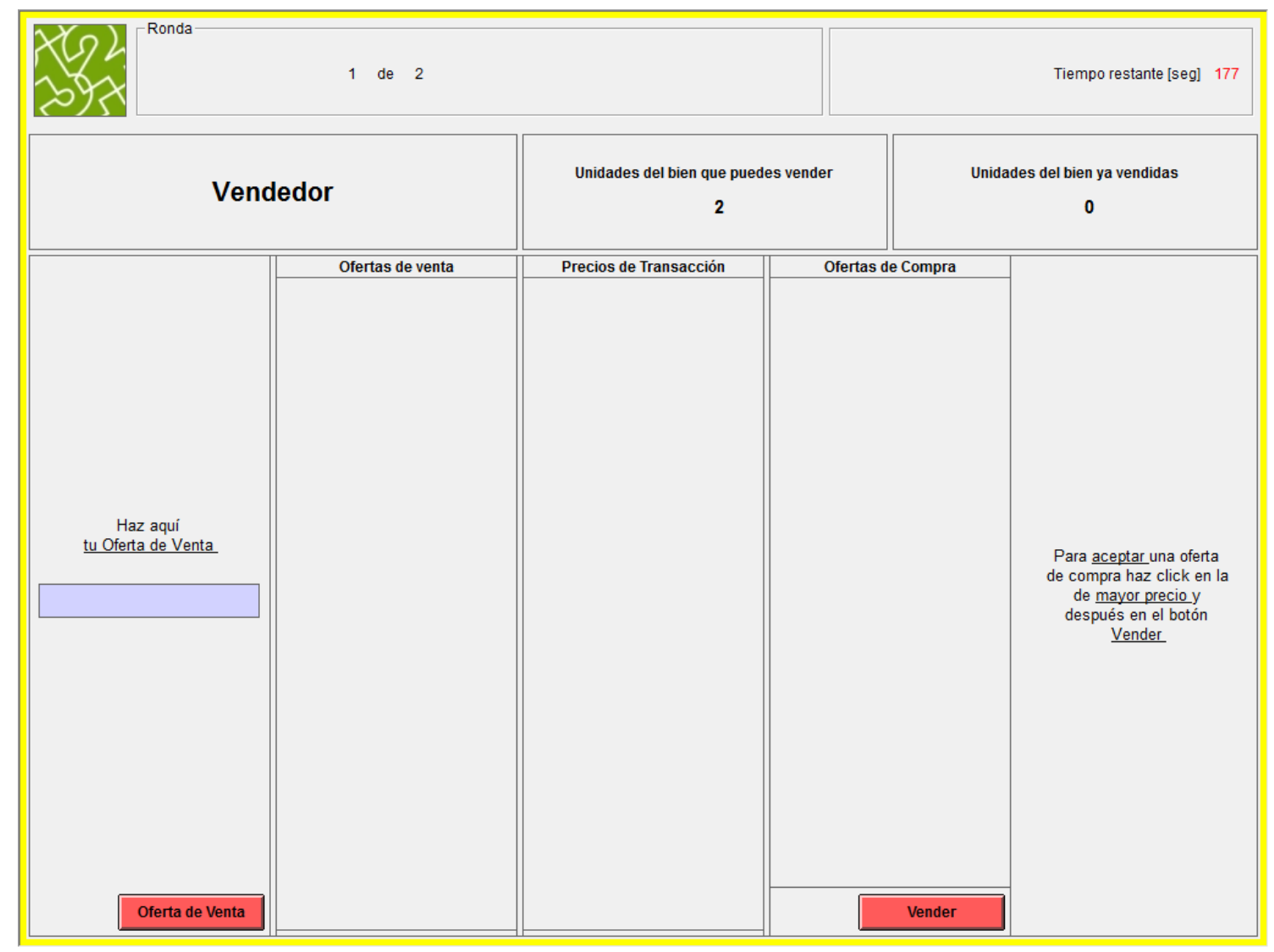

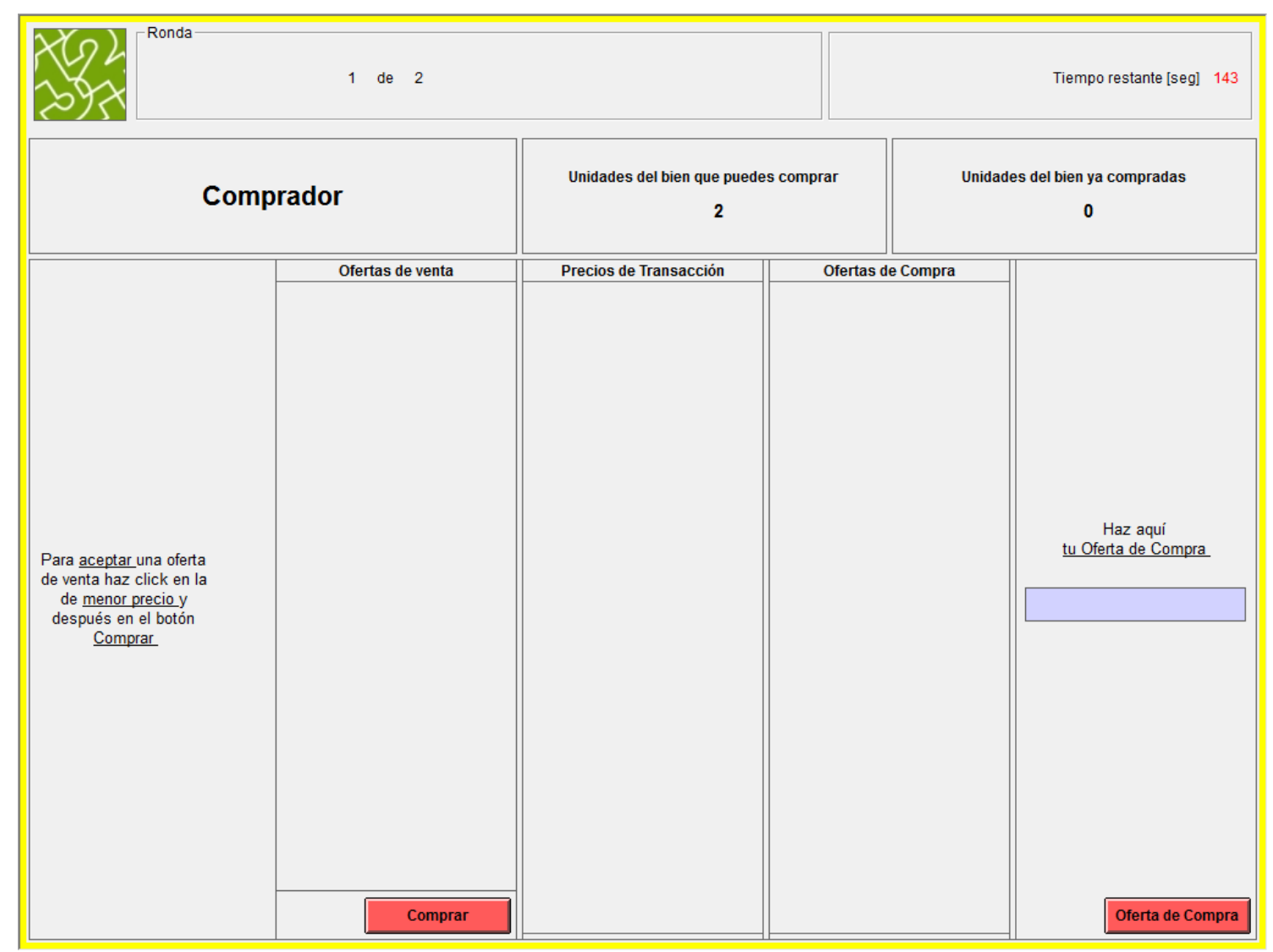


Se han hecho todas las transacciones posibles en el mercado

\begin{tabular}{|llll|r}
\hline Ronda- 1 de 2 & Tiempo restante [seg] 2 \\
\hline
\end{tabular}

El tiempo de ronda de mercado ha finalizado

(esta pantalla dura 3 segundos) 
Unidades compradas: 1

Ingreso en esta ronda: 90.0

Ingreso acumulado: $\quad 90.0$

\begin{tabular}{|c|c|}
\hline $\mathbf{N}^{0}$ de la Unidad & Precio \\
\hline 1 & 10.0 \\
\hline
\end{tabular}

Esta ha sido la última ronda del Mercado. Ahora participarás durante otras 6 rondas (rondas 19 a 24) en la otra situación de toma de decisiones mencionada en las instrucciones. 


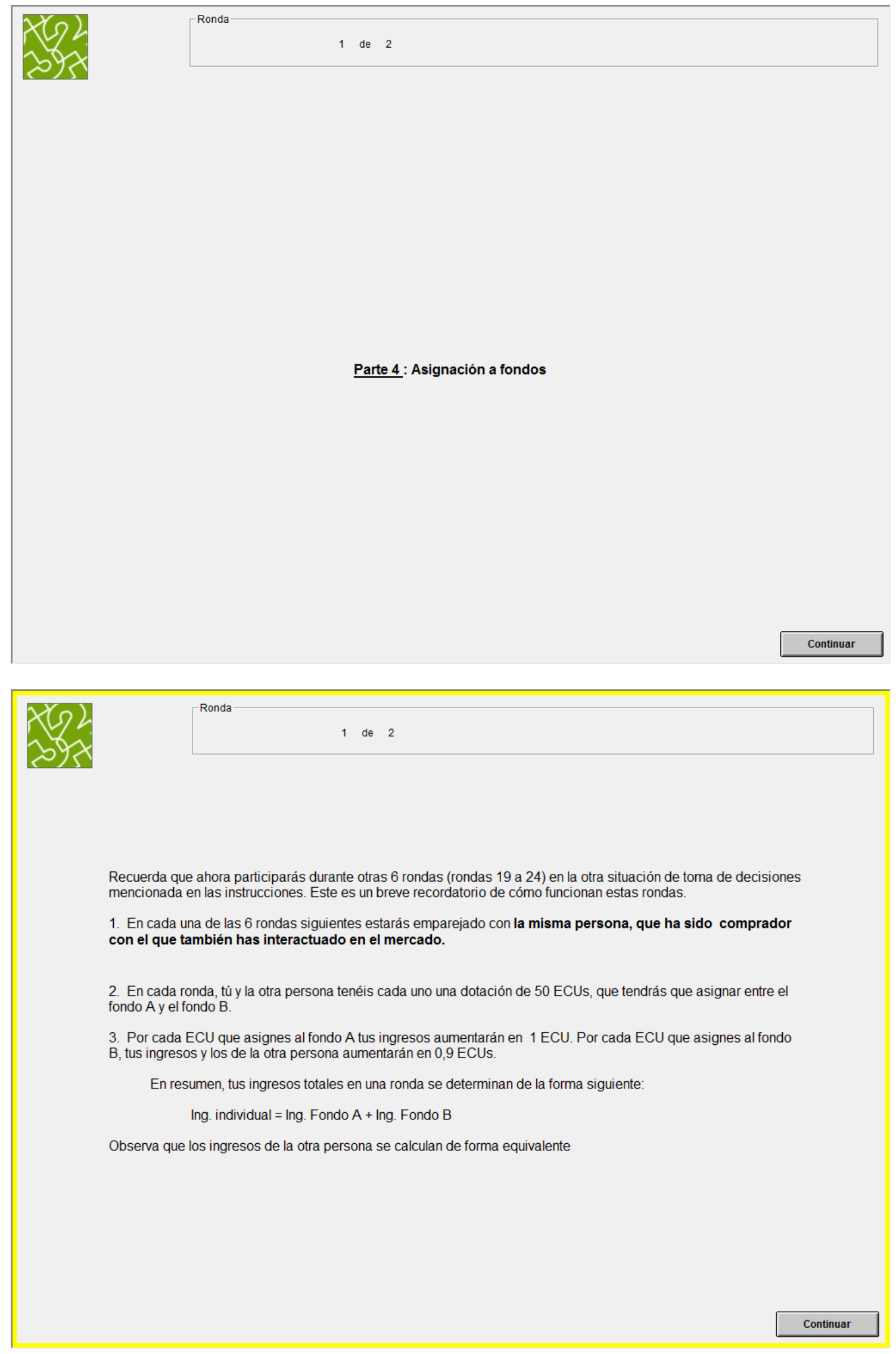




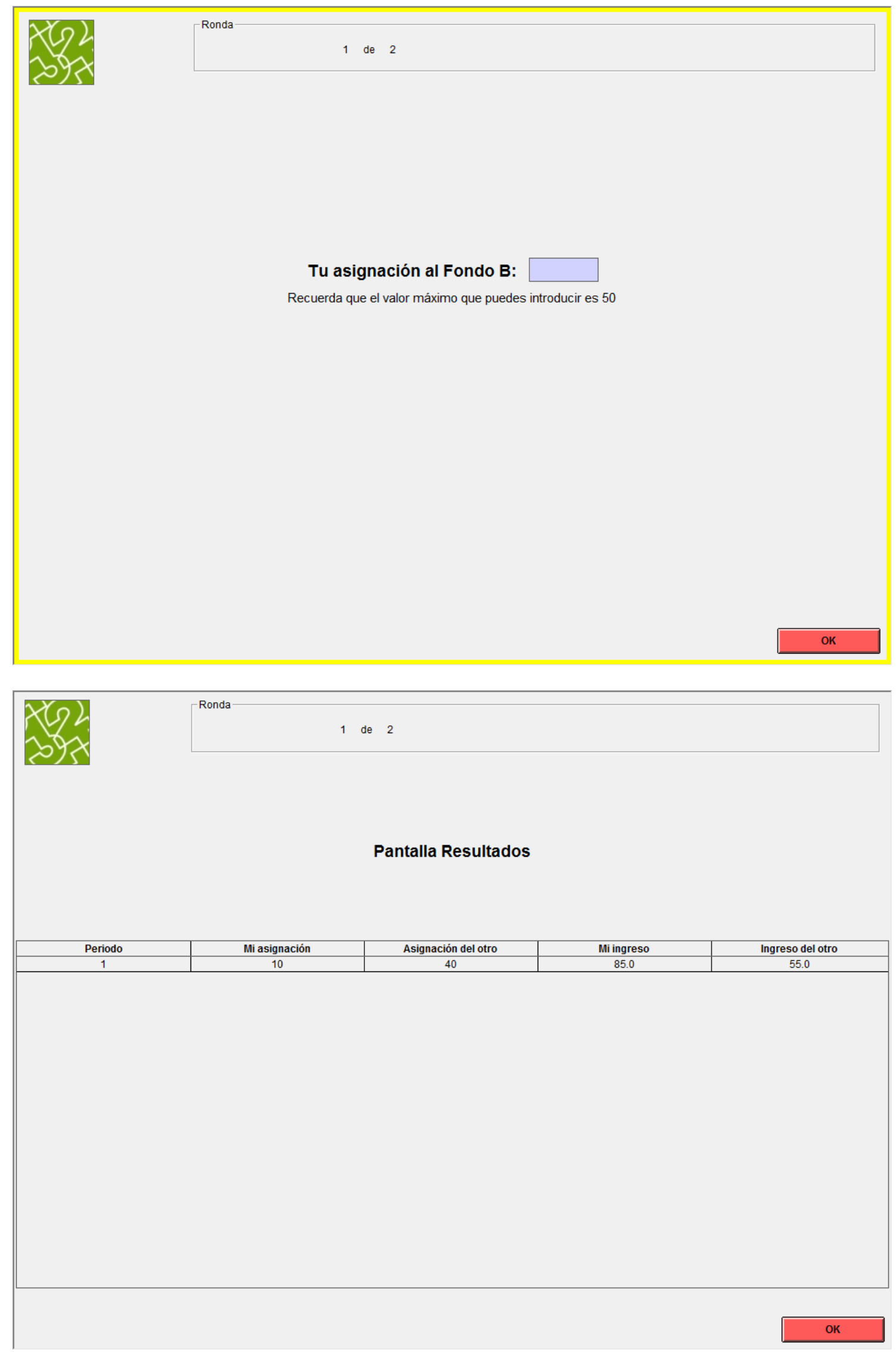




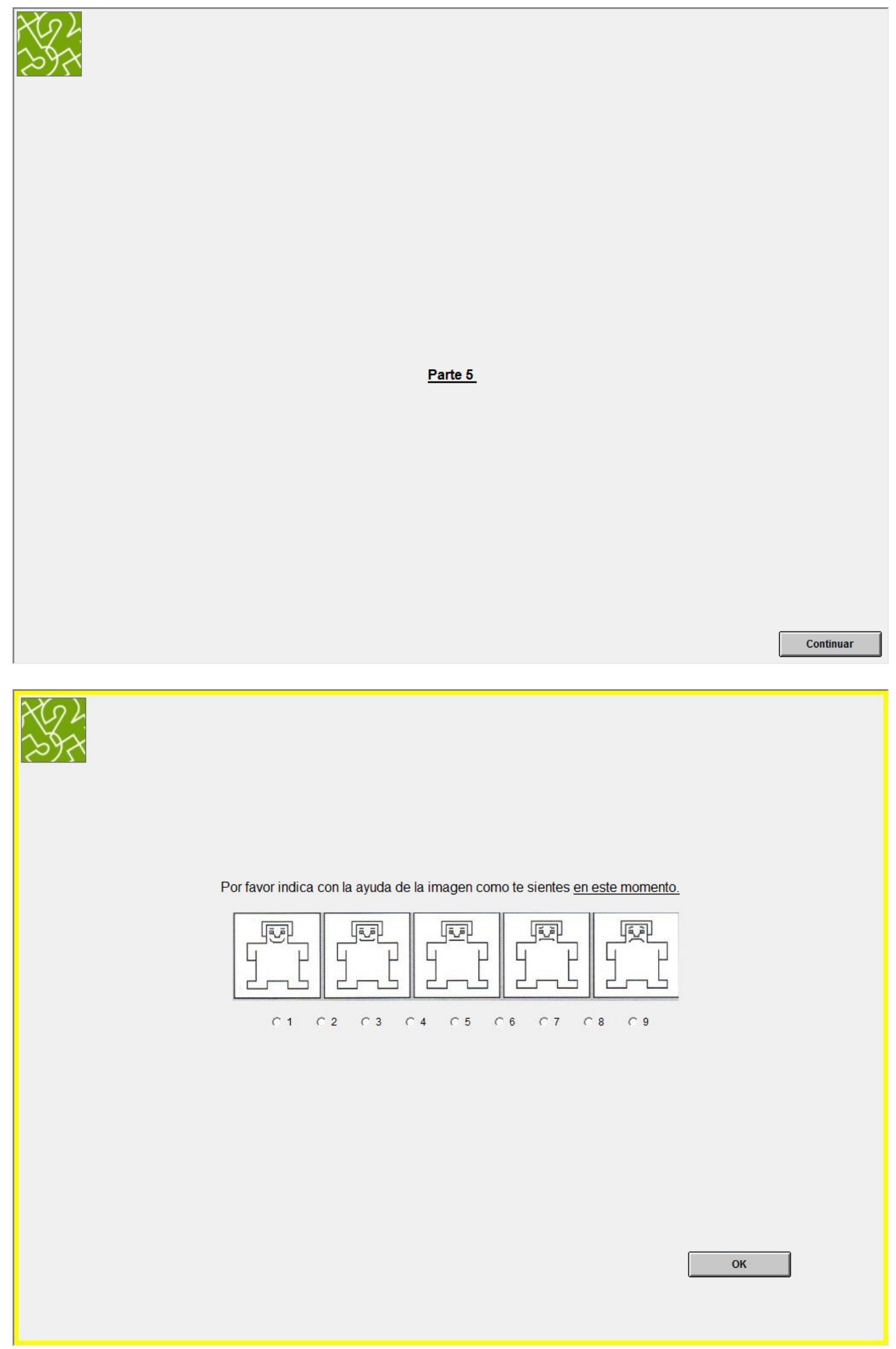


Parte 6: Círculo

Decisión

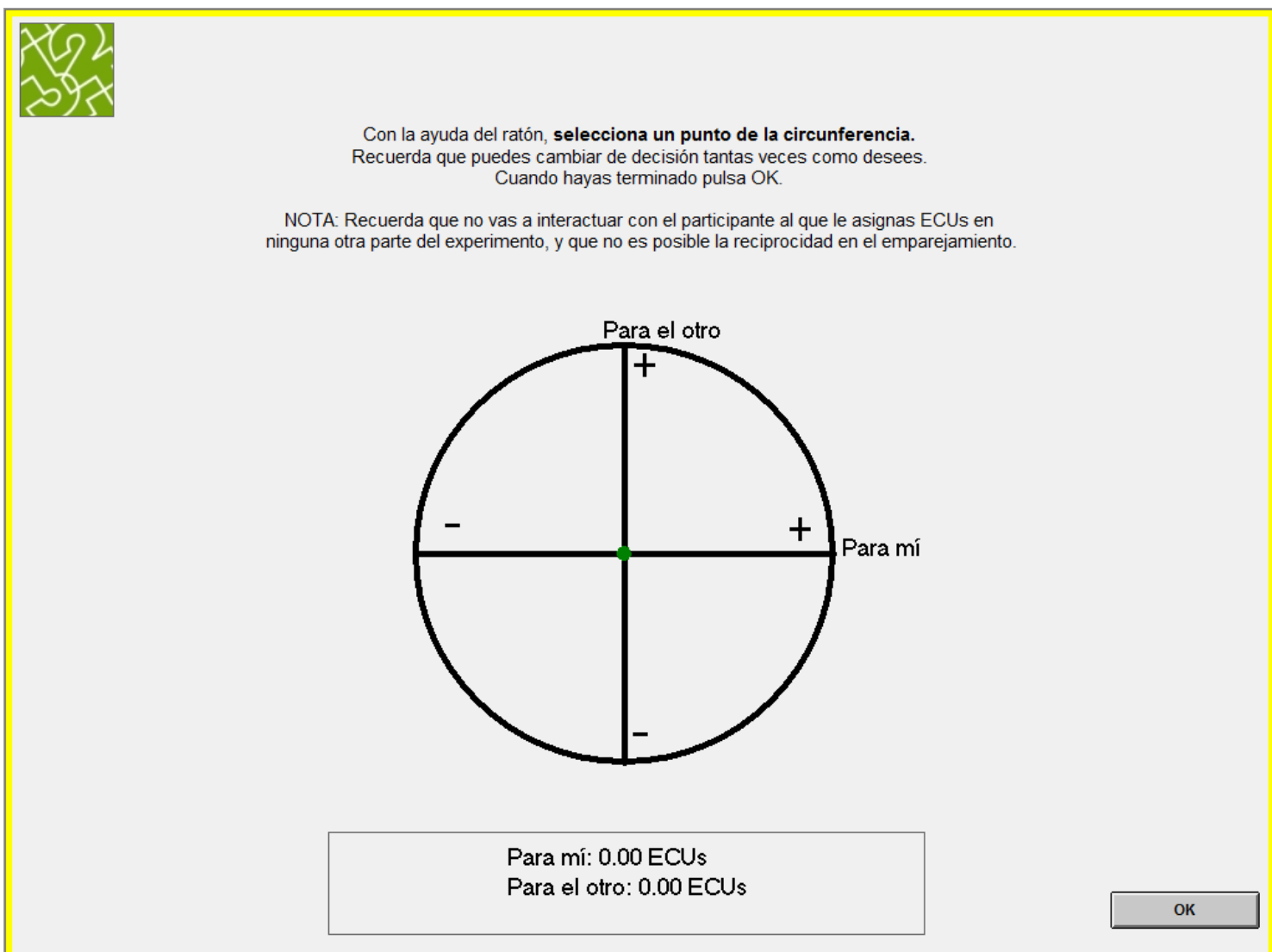




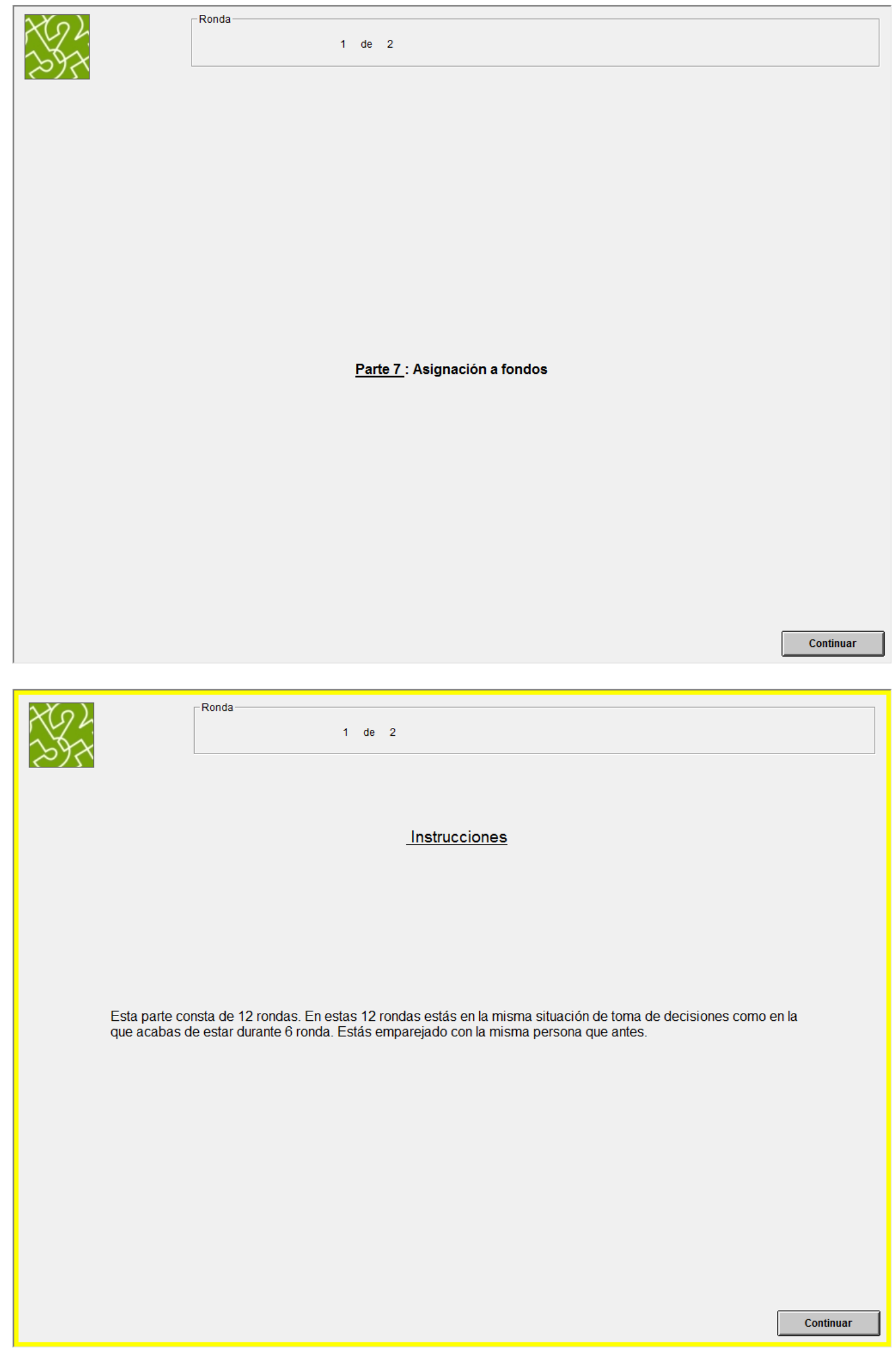




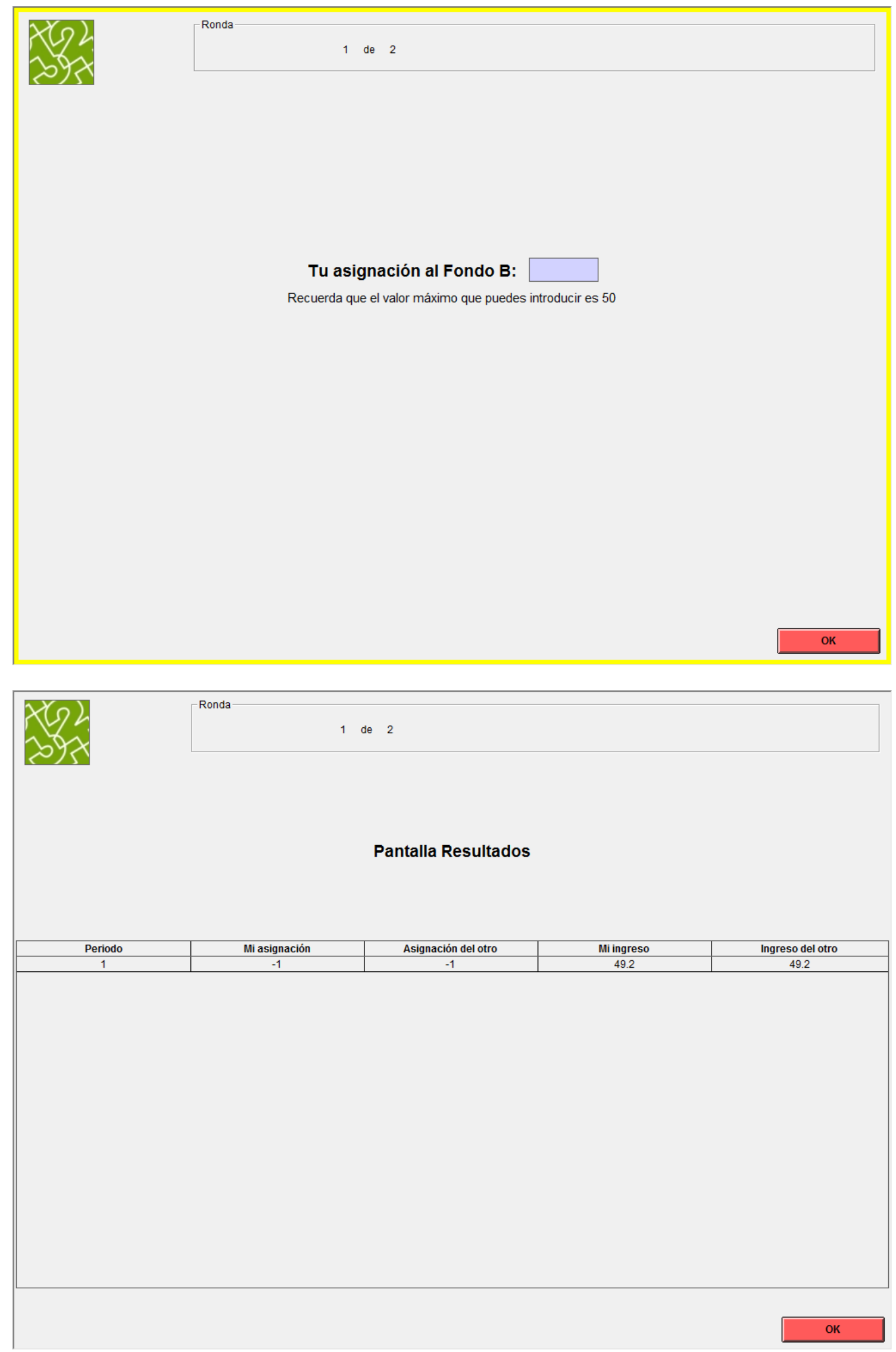


Resultados Finales

Parte 2: Círculo 1

Parte 3: Mercado

Parte 4: Asignaciones a fondos

Parte 6: Círculo 2

Parte 7: Asignaciones a fondos
Has seleccionado: $0.00 \mathrm{ECUs}$

Tu pareja ha seleccionado para ti: $0.00 \mathrm{ECUs}$

198.00 ECUs

98.40 ECUs

Has seleccionado: $0.00 \mathrm{ECU}$

Tu pareja ha seleccionado para ti: $0.00 \mathrm{ECUs}$

98.40 ECUs

Introduce tus datos personales, por favor.

Género

¿Qué edad tienes?

Nacionalidad

¿Qué titulación estudias?

¿En qué curso estás?

¿Cuántos, de los participantes en el experimento son amigos tuyos?

¿En cuántos experimentos has participado previamente?

¿Fueron claras las instrucciones?

Totalmente en contra $\stackrel{2}{c}$ masculino

$C$ femenino

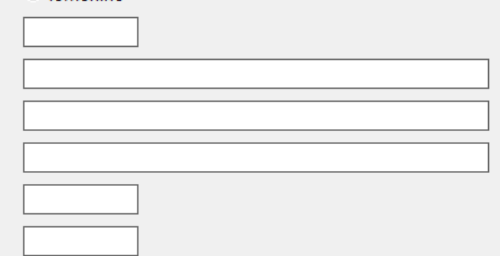

$\stackrel{6}{6} \quad \stackrel{7}{6}$

Totalmente a favor 


\section{GENERAL INSTRUCTIONS READ OUT ALOUD AT THE BEGINNING OF THE EXPERIMENT}

\section{Instructions}

Welcome to this experiment. The purpose of this experiment is to study how individuals make decisions in different situations. The instructions are simple and if you follow them carefully you can earn a considerable amount of money with the decisions you make. How much you earn may also depend on the decisions of other participants and on random events. The total amount of money you earn in the experiment will be paid out to you in cash confidentially at the end of the experiment. Nobody will learn the payments received by other participants. During the experiment you can ask questions at any moment. Please do not ask the questions aloud but raise your hand. One of the experimenter team will come to you to answer your question. Apart from these questions, any kind of communication other than specified in the instructions is not allowed and will lead to the immediate exclusion from the experiment.

1. This experiment consists of several parts. These are the "General Instructions" which apply to all parts of the experiment. You will receive the instructions for the different parts at the beginning of each part.

2. In some parts you will learn about (parts of) the earnings received but in some parts you will not learn your earnings immediately. Only at the end of the experiment, you will be informed about all your earnings in each part and your total earnings. In the experiment we will not talk of Euro but of ECU. At the end of the experiment, all your earnings will be exchanged at the exchange rate of

\section{$100 \mathrm{ECU}=1 \mathrm{EUR}$.}

3. At the beginning of each part, you will see the corresponding instructions on the screen or you will be handed over new instructions on paper. 
TRANSLATED INSTRUCTIONS AND SCREENS FOR MARKET STRANGERS

Screen 1

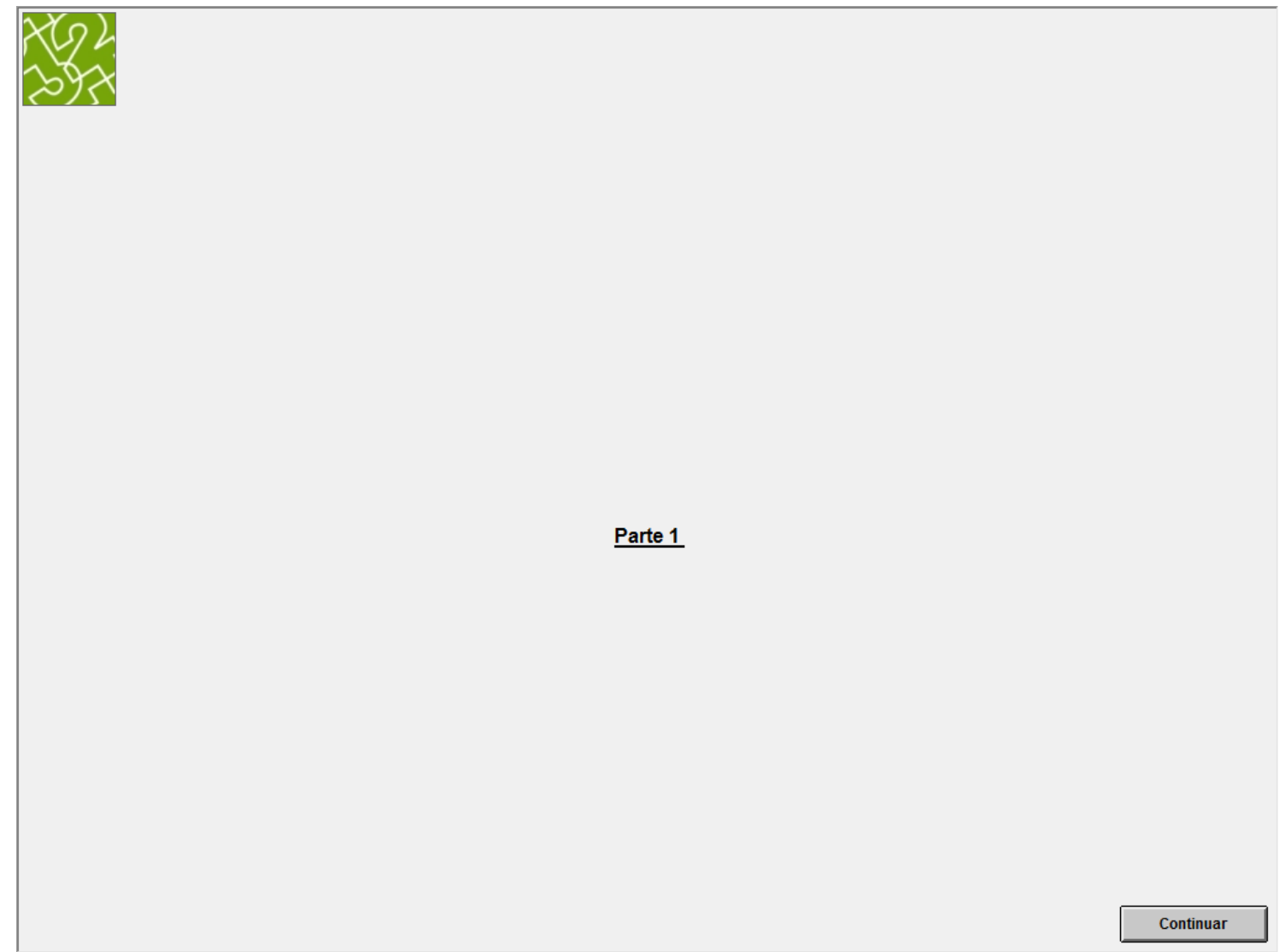

Part1 
Screen 2

Por favor indica con la ayuda de la imagen como te sientes en este momento

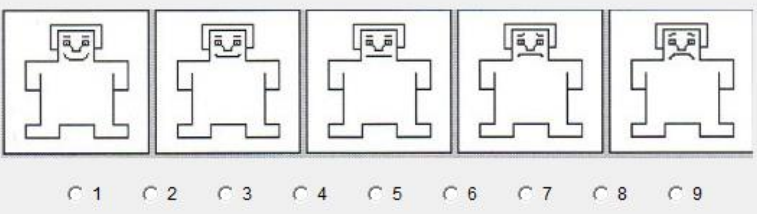

Please indicate with the help of the image how you feel at this moment. 
Screen 3

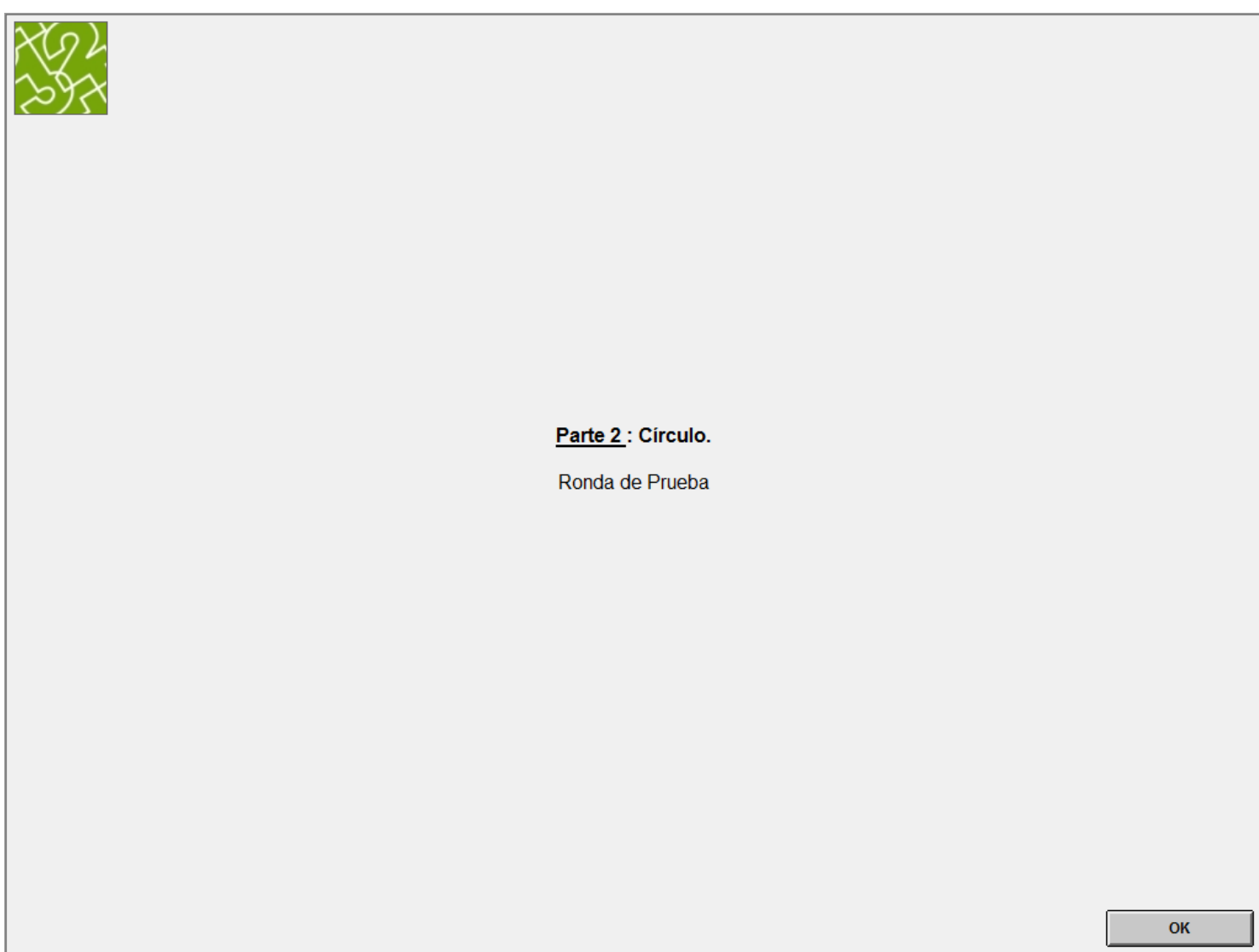

Part 2: Circle

Trial Round 


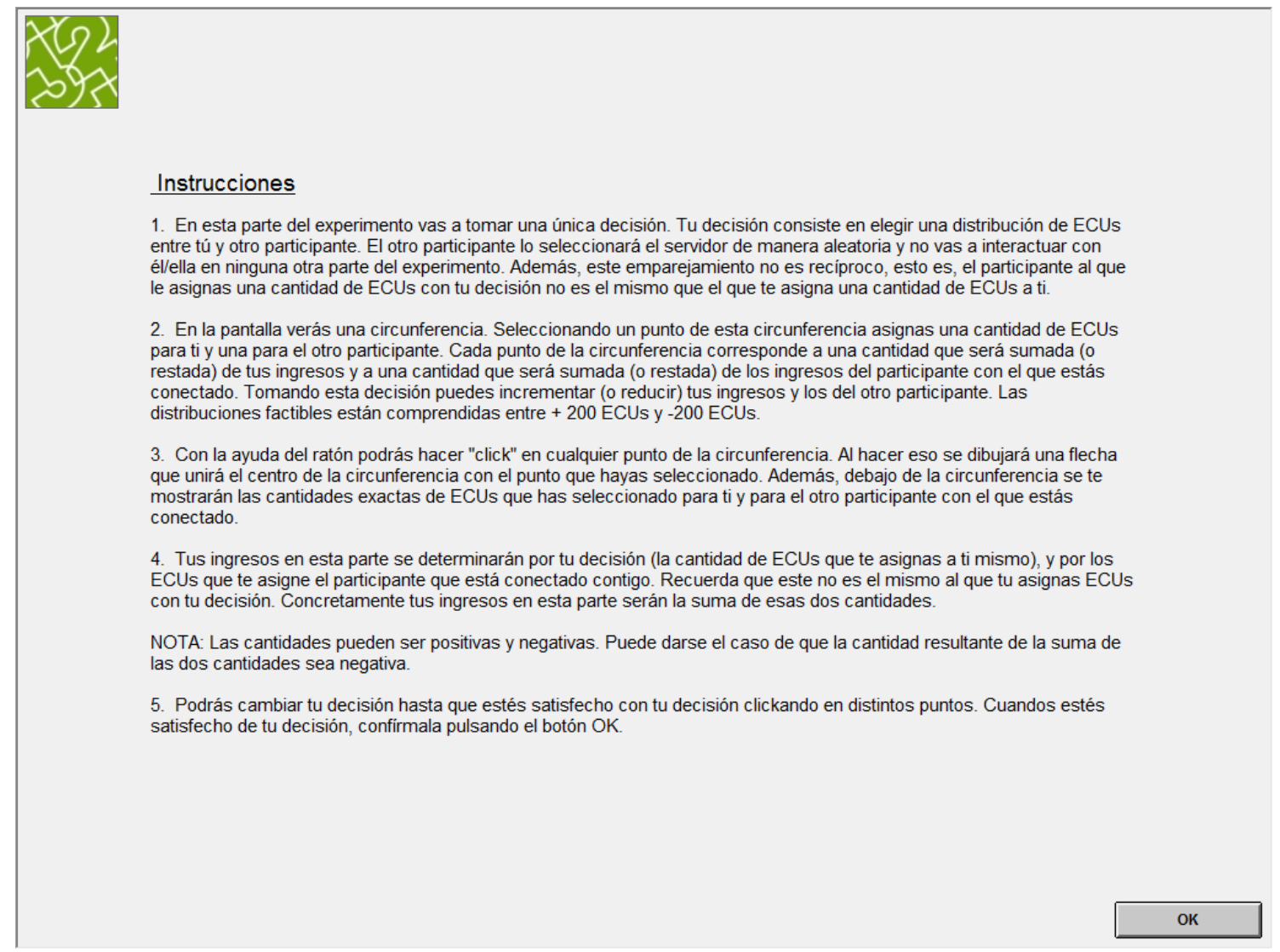

$\underline{\text { Instructions }}$

1. In this part of the experiment you are going to take just one decision. Your decision consists in choosing a distribution of ECUs between you and another participant. The server will choose the other participant randomly and you are not going to interact with him/her in any other part of the experiment. Furthermore, this matching is not reciprocal, that is the other participant, to whom you can allocate an amount of ECUs with your decision, is not the same who can allocate an amount of ECUs to you.

2. You are going to observe a circle on the screen. By choosing a point on this circle you allocate an amount of ECUs to you and to the other participant. Each point on the circle corresponds to an amount that will be added to (or subtracted from) your earnings and the other participant's earnings with whom you are connected. By taking your decision you can increase (or reduce) your earnings and the earnings of the other participant. The feasible distributions range from +200 ECUs to -200 ECUs.

3. With the help of the mouse you will be able to click on any point on the circle. If you do that an arrow will be drawn, which connects the center of the circle with the point that you will have selected. Moreover, the exact amount of ECUs that you have selected for you and for the other participant will be shown below the circle.

4. Your earnings in this part will be determined by your decision (the amount of ECUs that you allocate to yourself), and by the ECUs that the participant who is connected with you allocates to you. Remember that the latter is not the same than the one to whom you allocate ECUs with your decision. Concretely, your earnings in this part will be the sum of these two amounts.

NOTE: The amounts can be positive or negative. It can be the case that the sum of the two amounts is negative.

5. You will be able to change your decision until you are satisfied with your decision by clicking on different points on the circle. When you are satisfied with your decision you have to confirm it by clicking on the OK button. 


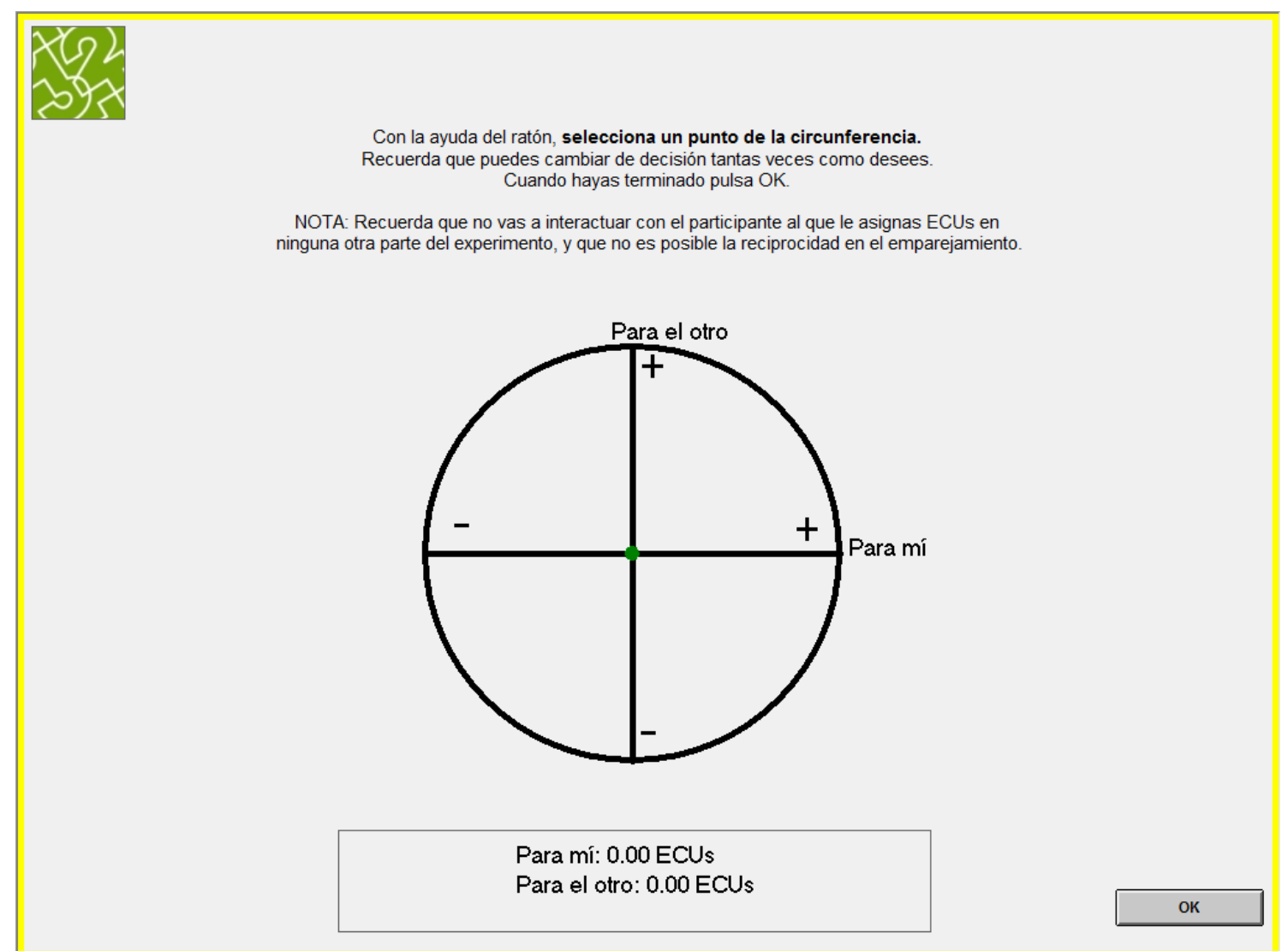

With the help of the mouse select a point on the circle. Remember that you can change your decision as many times as you wish.

When you are finished press OK.

NOTE: Remember that you will not interact with the participant to whom you assign ECUs in no other part of the experiment and that reciprocity in the matching.

FOR ME: 0.00 ECUs

FOR THE OTHER: 0.00 ECUs 
Screen 6

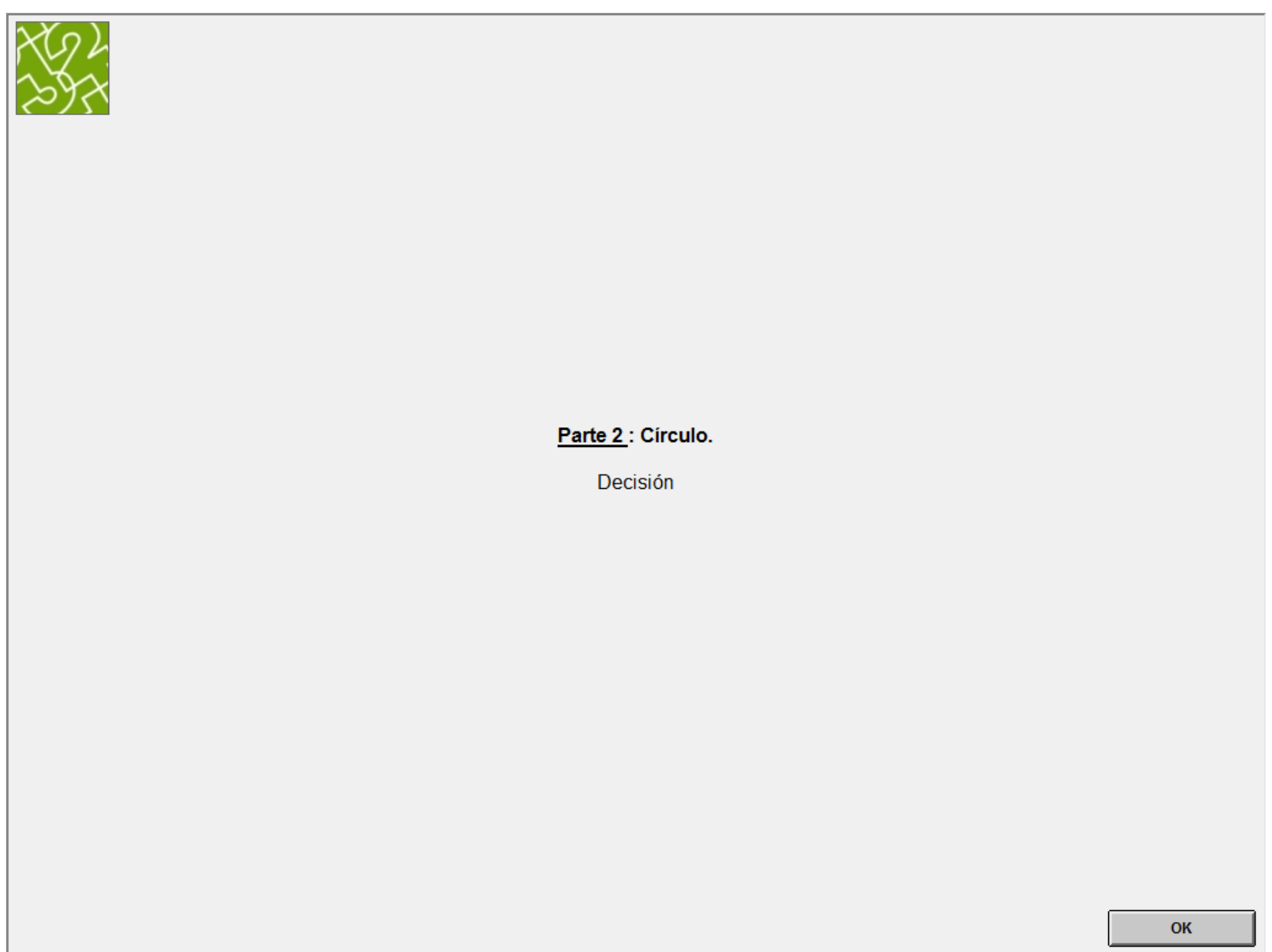

Part 2: Circle

Decision 


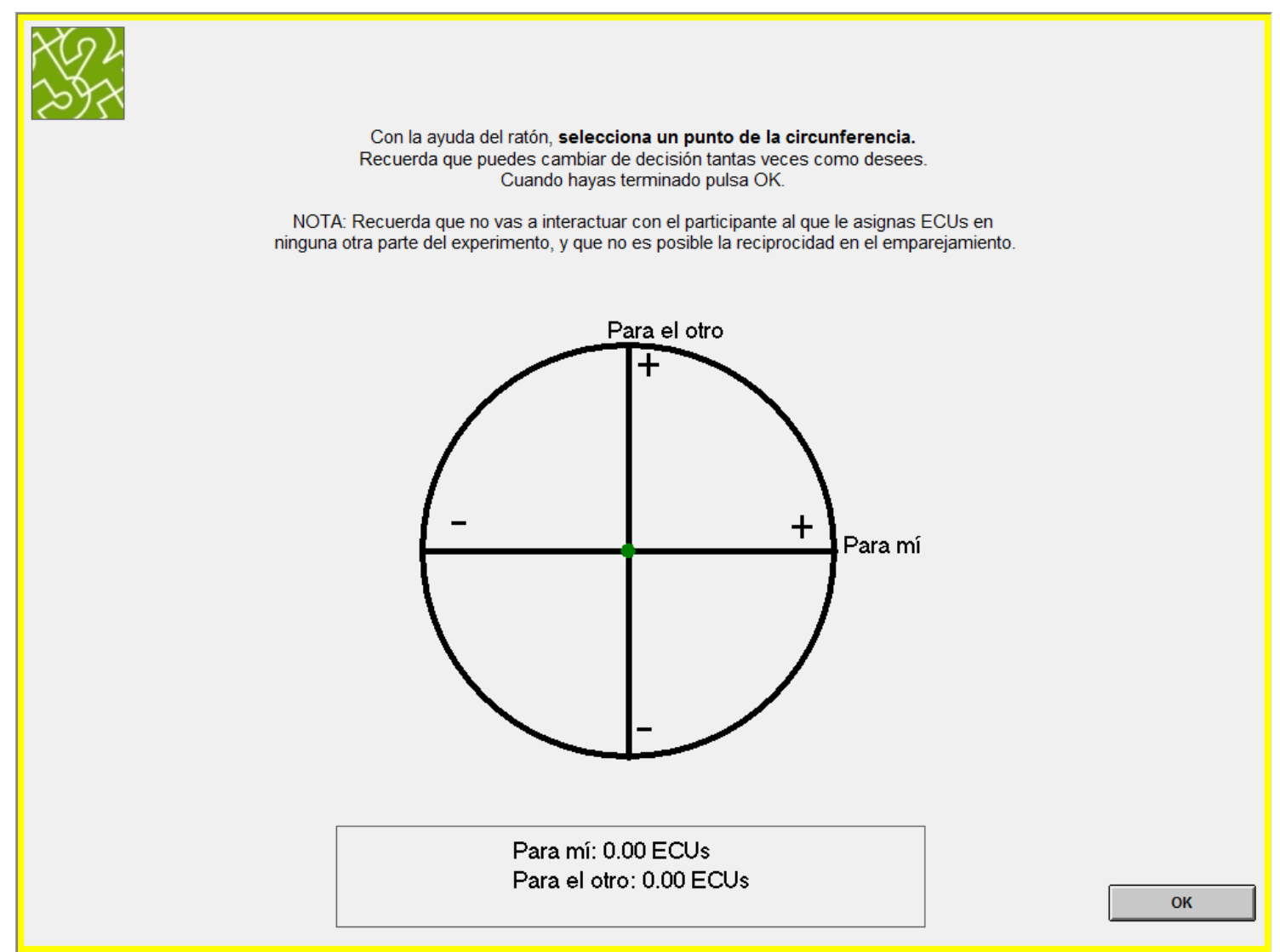

With the help of the mouse select a point on the circle. Remember that you can change your decision as many times as you wish.

When you are finished press OK.

NOTE: Remember that you will not interact with the participant to whom you assign ECUs in no other part of the experiment and that reciprocity in the matching.

FOR ME: 0.00 ECUs

FOR THE OTHER: 0.00 ECUs 
Screen 8

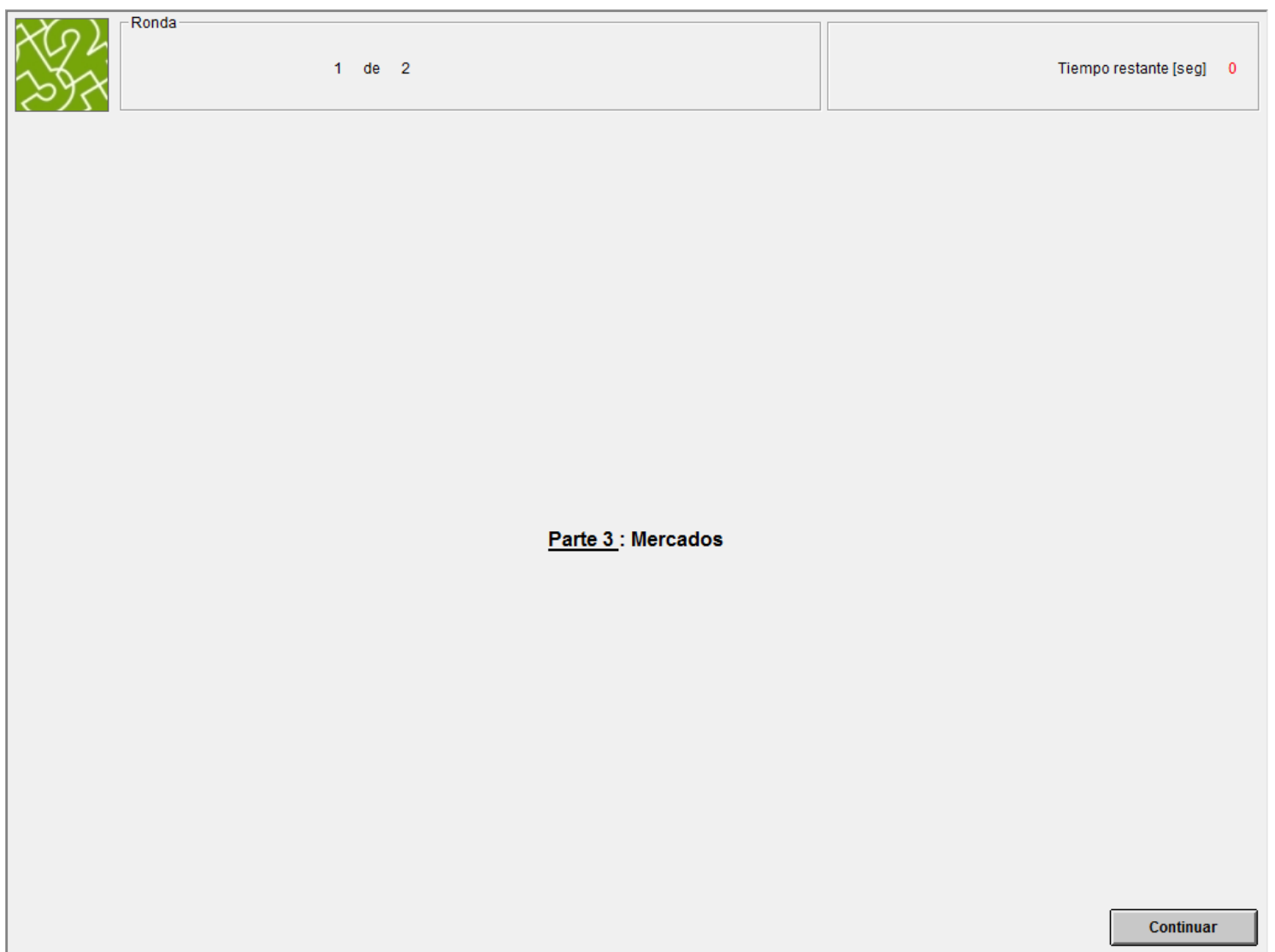

Part 3: Markets 


\section{BUYERS}

\section{Screen 9}

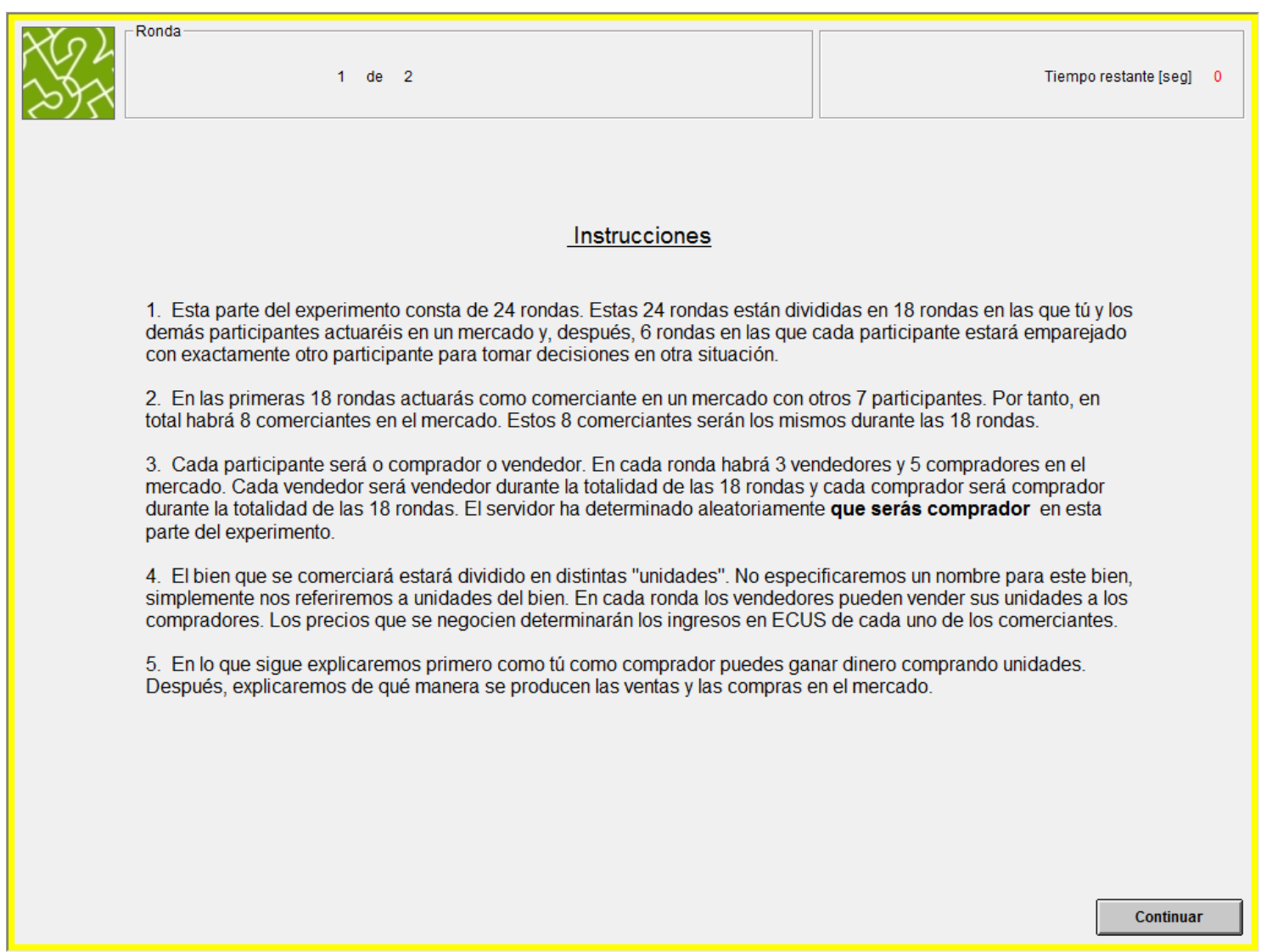

\section{Instructions}

1. This part of the experiment consists of 24 rounds. These 24 rounds are split into 18 rounds in which you and the other participants will act in a market and, thereafter, 6 rounds where each participant will be paired with exactly one other participant to make decisions in another situation.

2. In the first 18 rounds you will act as a trader in a market with 7 other participants. Hence, in total there will be 8 traders active in the market. These 8 traders will stay the same for all 18 rounds.

3. Each participant will be either a buyer or a seller. In each round there will be 3 sellers and 5 buyers active in the market. Each seller stays a seller throughout all 18 rounds and each buyer stays a buyer for all 18 rounds. The server has randomly determined that you will be a buyer in this part of the experiment.

4. The good to be traded is divided into distinct "units". We will not specify a name for the good but simply refer to units of the good. In each round sellers can sell their units to the buyers. The prices that are negotiated will determine each trader's earnings in ECUs.

5. In the following we will first explain how you as a buyer can earn money through purchasing units. Thereafter, we will explain how sales and purchases are take place in the market. 


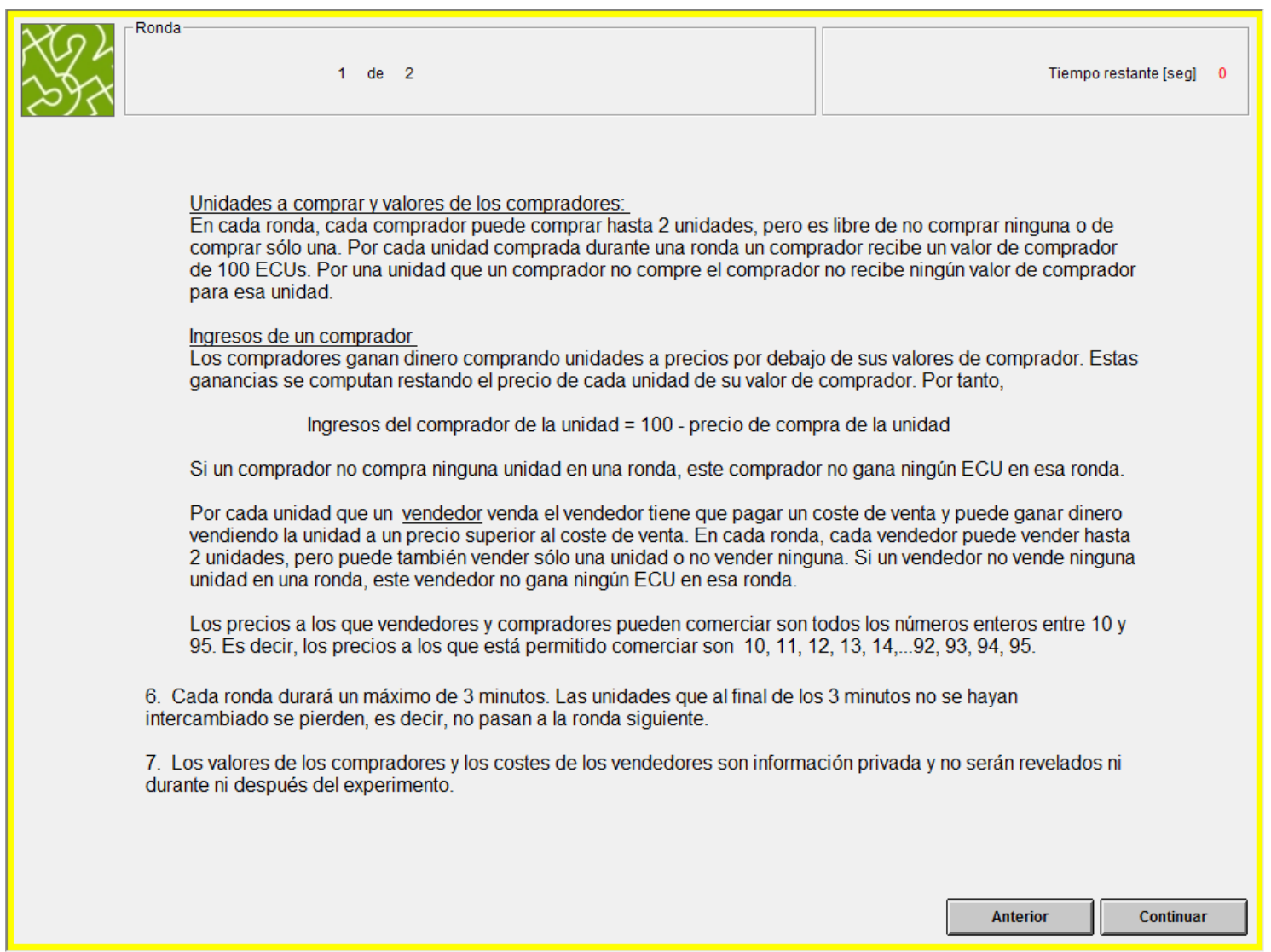

Units to buy and buyer values:

In each round, each buyer can buy up to 2 units, but is free to buy no or only one unit. For each unit purchased during a round a buyer receives a buyer value of 100 ECUs. For a unit a buyer does not purchase the buyer does not receive any buyer value for that unit.

\section{Buyer earnings:}

Buyers make profits by purchasing units at prices that are below their buyer values. These profits are computed by subtracting each unit's price from its buyer value. Therefore,

$$
\text { buyer's earnings per unit }=100 \text { - purchasing price for unit. }
$$

If a buyer does not purchase any unit in a round, this buyer does not earn any ECU's in this round.

For each unit a seller sells, the seller has to pay selling costs and can earn money by selling the unit at a price higher than the selling costs. In each round, each seller can sell at most 2 units, but may also sell no or only one unit. If a seller does not sell any unit in a round, this seller does not earn any ECU's in this round.

The prices at which sellers and buyers are allowed to trade are all inter numbers between 10 and 95 . That is the permitted trading prices are $\{10,11,12,13,14, \ldots, 92$, $93,94,95\}$.

6. Each round will last a maximum of 3 minutes. The units that have not been exchanged at the end of the 3 minutes are lost, that is, they are not carried over to the next round.

7. Buyer values and seller costs are private information and will not be revealed neither during nor after the experiment. 


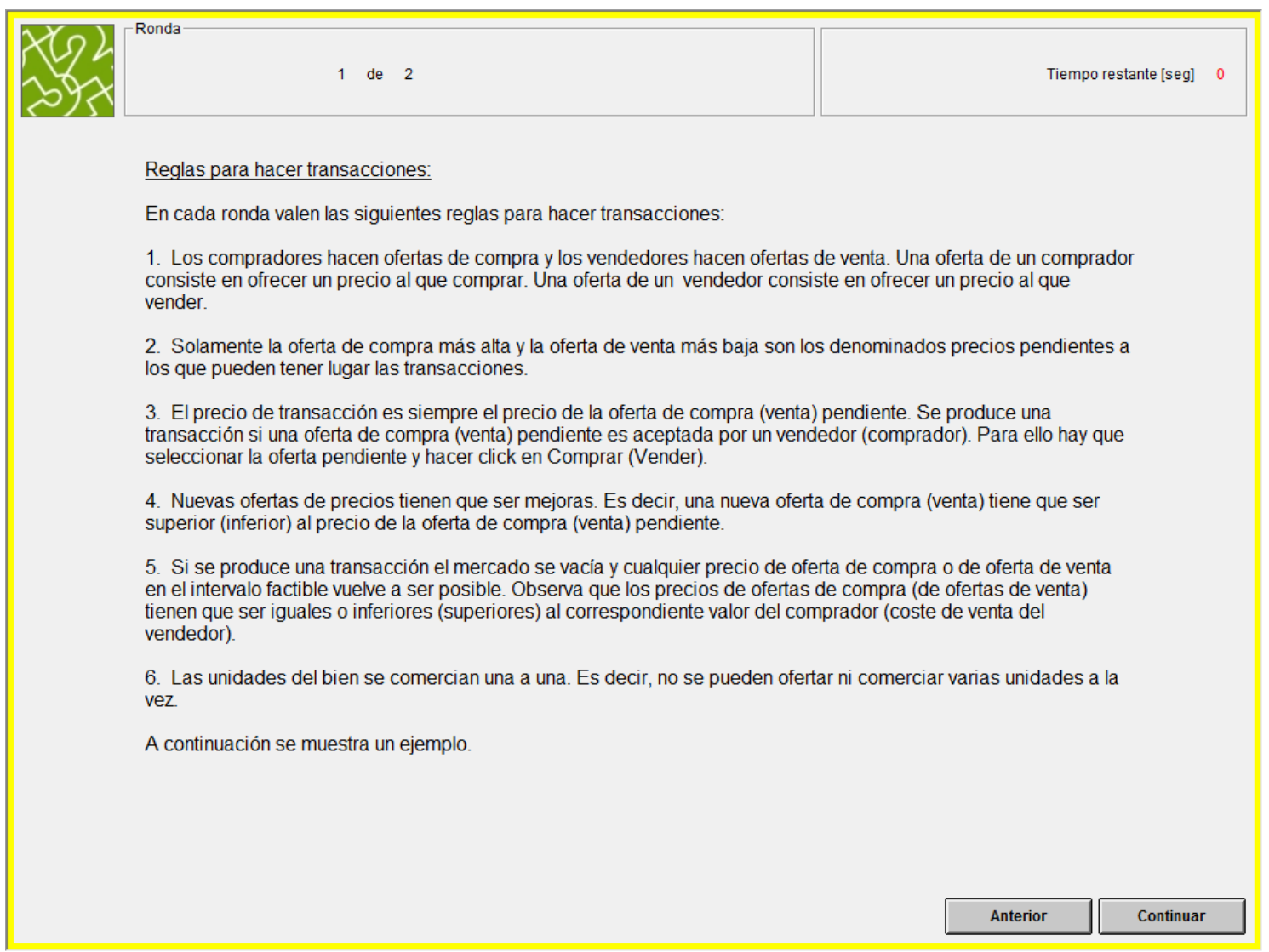

\section{$\underline{\text { Rules for making transactions }}$}

In each round there are the following rules for making transactions:

1. Buyers make buying offers and sellers make selling offers. A buying offer consists offering a price at which to purchase. A selling offer consists in offering a price at which to sell.

2. Only the highest buying offer and the lowest selling offers are the so-called standing prices at which trades can take place.

3. The transaction price is always the standing buying (selling) price. A transaction takes place if the standing buying (selling) is accepted by a seller (buyer).

4. Newly submitted price offers have to be improvements. That is, a new buying (selling) price has to be higher (lower) than the standing buying (selling) price.

5. If a transaction takes place the market clears and any buying and selling price in the feasible range are possible again. Note, that the prices of the buying offers (selling offers) bid (ask) prices have to be equal or lower (higher) than the corresponding buyer value (seller selling cost).

6. The units of the goods are traded one by one. That is, it is not possible to offer or exchange several units at the same time.

In what follows we show you an example. 


\section{Screen 12}

This is the screen a buyer faces when making and accepting offers in a round, which is explained on the next screen.

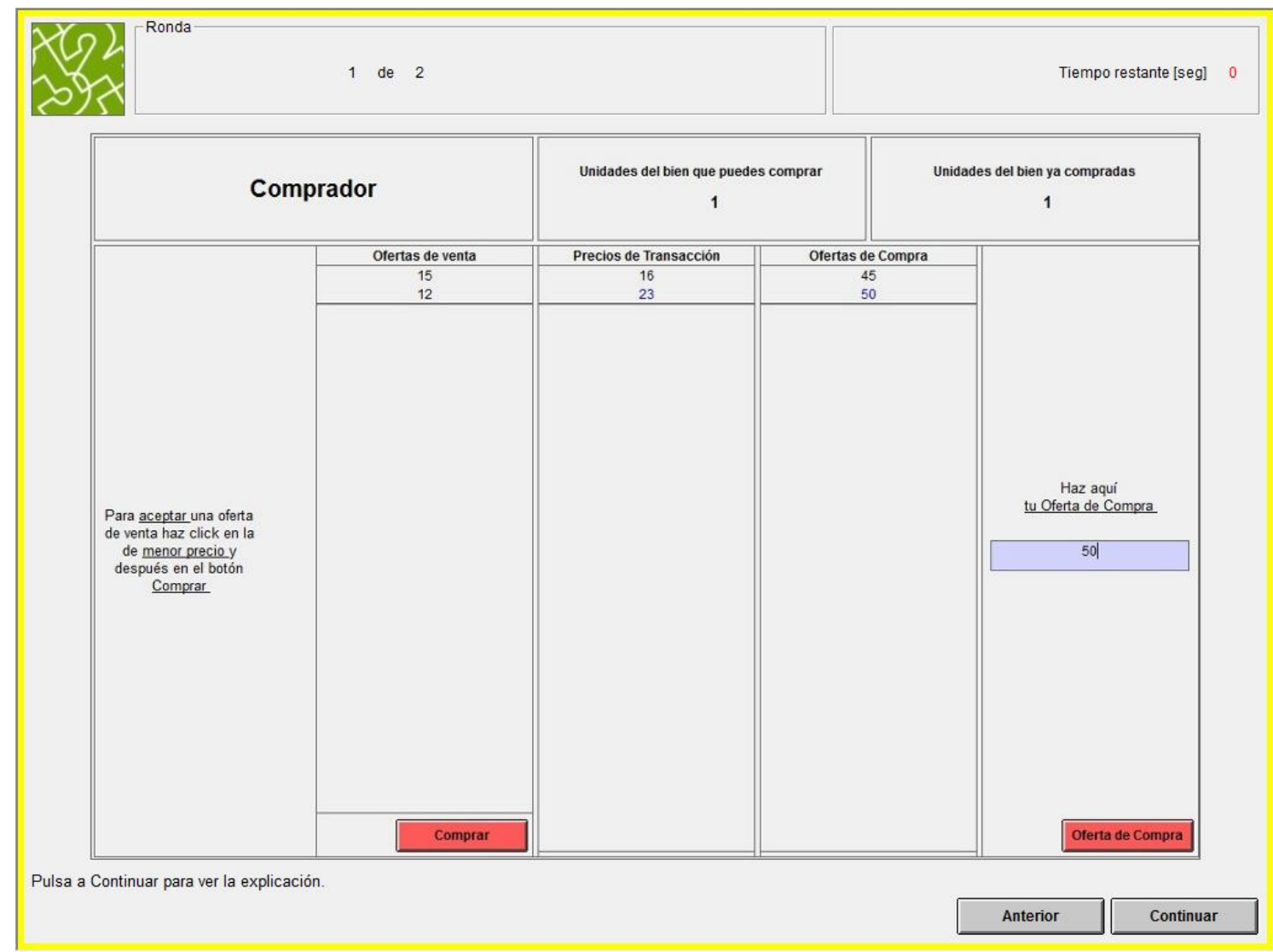




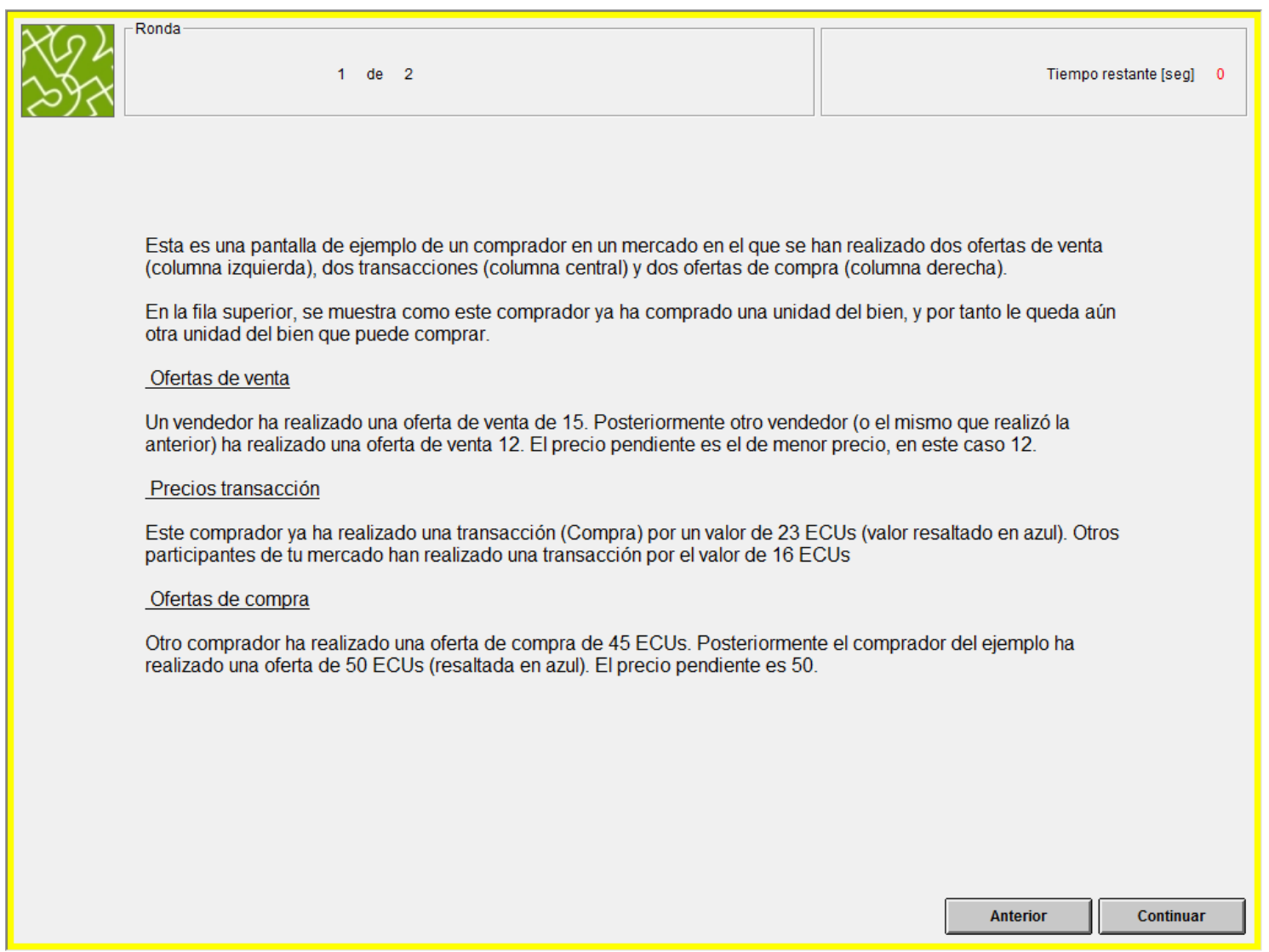

This is an example screen of a buyer in a market in which two selling offers (left column), two transaction (central column) and two buying offers (right column) have been made.

In the top row, it is shown that this buyer has already purchased one unit of the good, and therefore he still can buy one other unit.

\section{$\underline{\text { Selling offers }}$}

A seller has made a selling offer of 15 . After that another seller (or the same that made the earlier offer) has made a selling offer of 12 . The standing price is the lower price, in this case 12.

\section{Transaction prices}

This buyer has already made one transaction (purchase) for a value of 23 ECUs (value shown in blue). Other participants of your market have made a transaction for a value of 16 ECUs.

\section{Buying offers}

Another buyer has made a buying offer of 45 ECUs. After that the buyer of the example has made an offer of 50 ECUs (highlighted in blue). The standing price is 50. 
Screen 14

This screen is the same as screen 12, but with the highlighted items mentioned on screen 13.

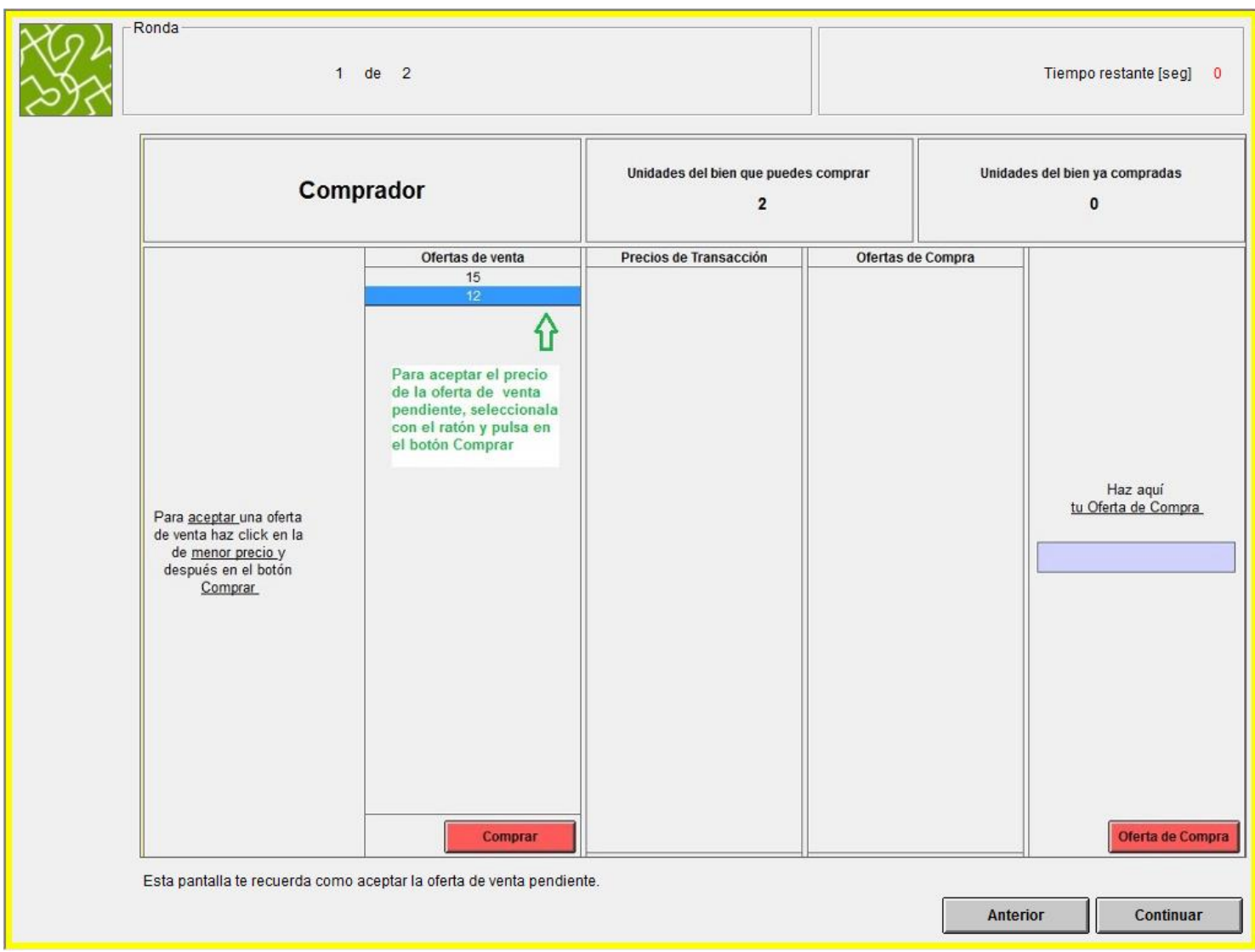


Screen 15

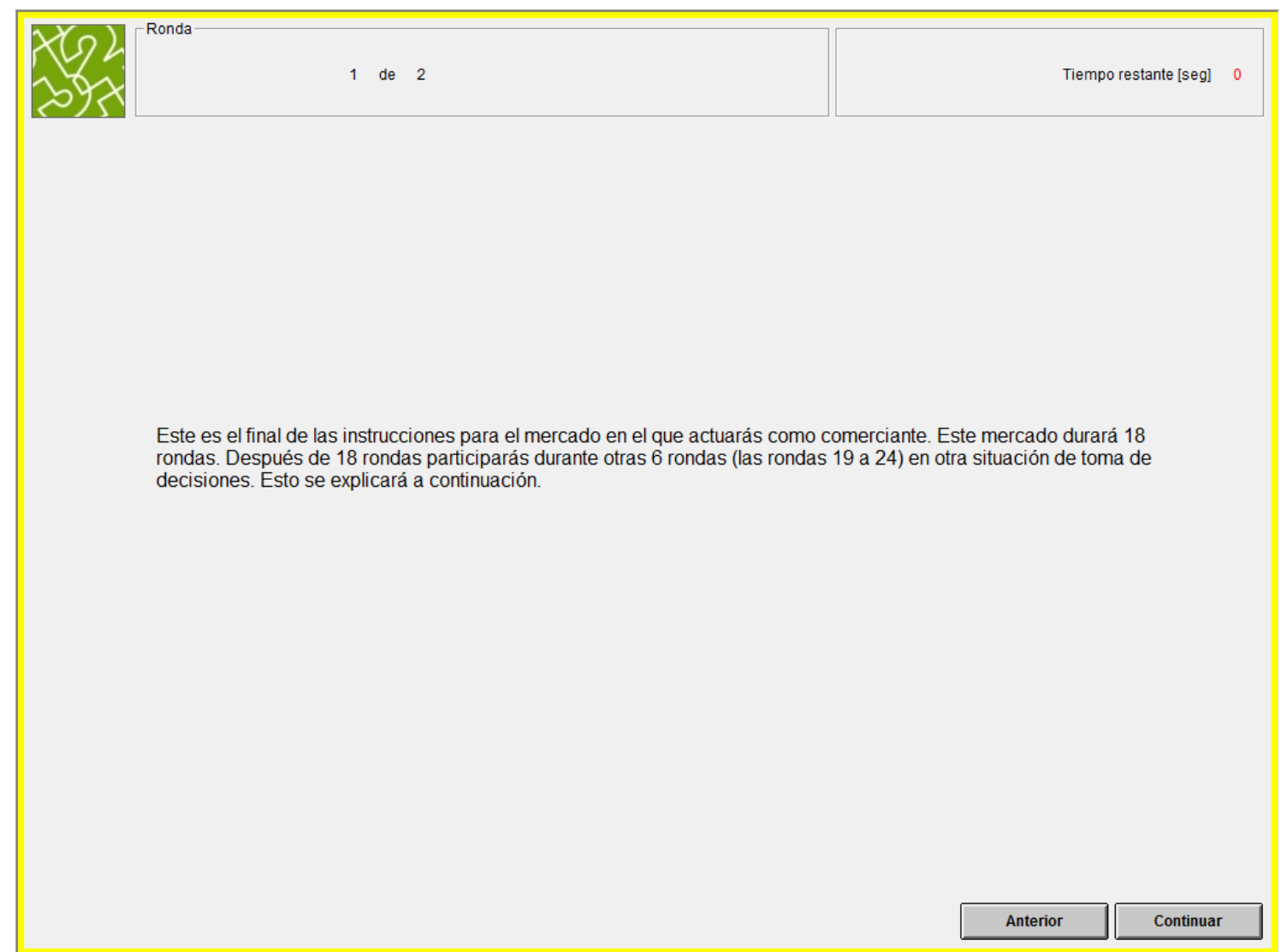

This is the end of the instructions for the market where you will act as a trader. This market will last for 18 rounds. After 18 rounds you will participate for another 6 rounds (rounds 19 to 24) in another decision making situation. This will be explained below. 


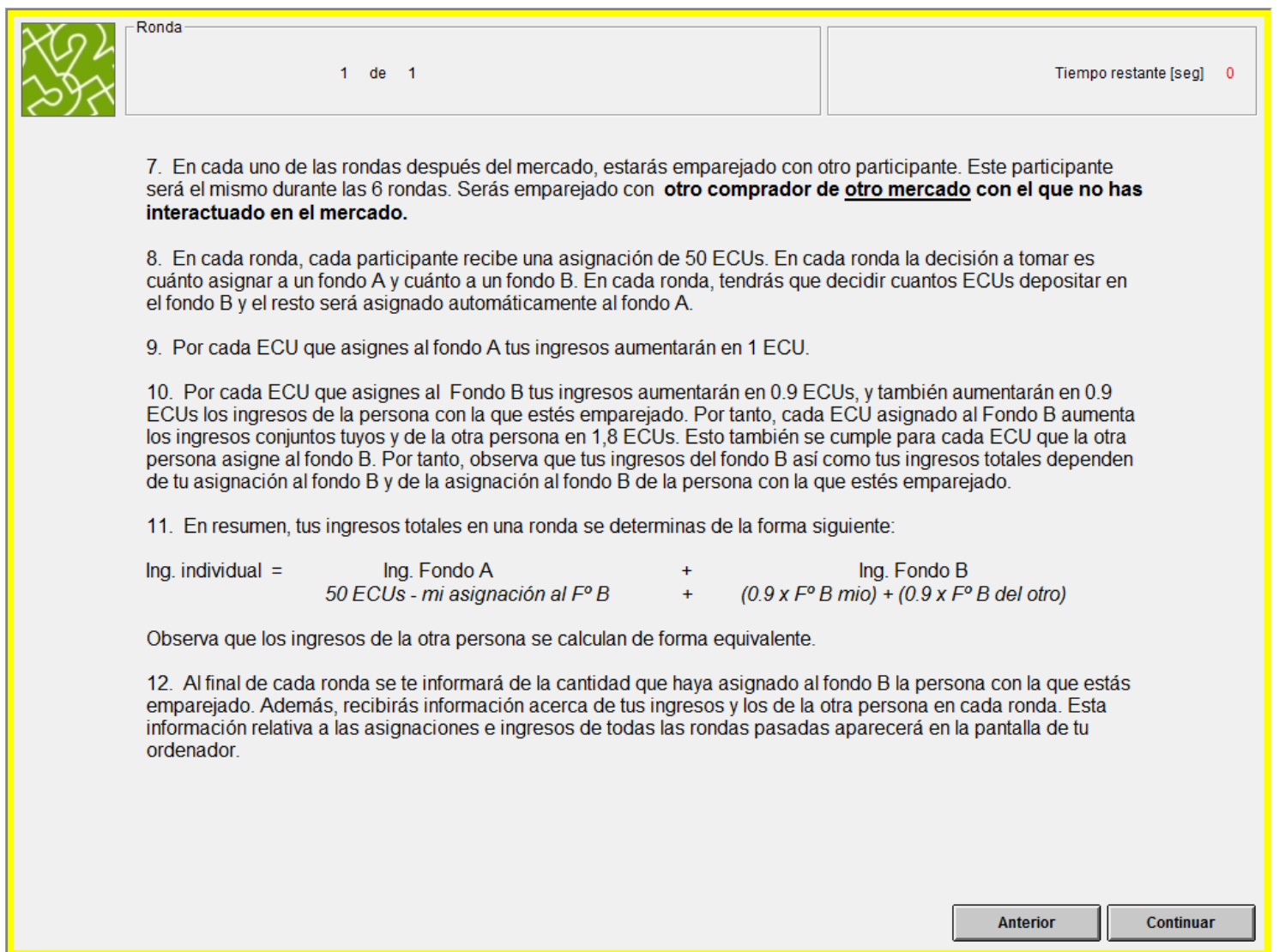

7. In each of the rounds that follow the market, you are paired with one other participants. This other participant will be the same throughout these 6 rounds. You will be paired with another buyer from another market with whom you have not interacted in the market.

8. In each round, each participant receives an endowment of 50 ECUs. In each round the decision to be made is to choose how much you allocate to a Fund A and to a Fund B. In each round, you will have to decide how many ECUs to deposit in fund B and the rest will be allocated to fund A automatically.

9. For each ECU that you allocate to fund A your earnings will increase by 1 ECU.

10. For each ECU that you allocate to fund B, your earnings will increase by 0.9 ECUs, and also the earnings of the other person you are paired with will increase by 0.9 ECUs. Hence, each ECU allocated to fund B increases your and the other's earnings together with 1.8 ECU. This also holds for each ECU the other person allocates to fund B. Hence, note that your earnings from fund B as well as your total earnings, depend on your allocation to fund B and on the allocation to fund B of the person you are paired with.

11. In summary, your total earning in one round are determined in the following way:

$\begin{array}{lll}\begin{array}{l}\text { Individual earnings } \\ =\end{array} & \text { Earnings fund } \mathrm{A}+ & \begin{array}{l}\text { Earnings fund } \mathrm{B} \\ 50 \mathrm{ECU}-\text { my allocation to fund } \mathrm{B}+\begin{array}{l}(0.9 \times \text { my allocation to fund } \mathrm{B})+ \\ (0.9 \times \text { other person's allocation } \\ \text { to fund } \mathrm{B})\end{array}\end{array}\end{array}$

Note, that the earnings of the other person are calculated in an equivalent way.

12. At the end of each round, you will be informed of the allocation to fund B of the person you are paired with. Moreover, you will receive information on your and the other person's earnings in each round. This information regarding the allocation and earnings of all previous rounds will appear on your computer screen. 


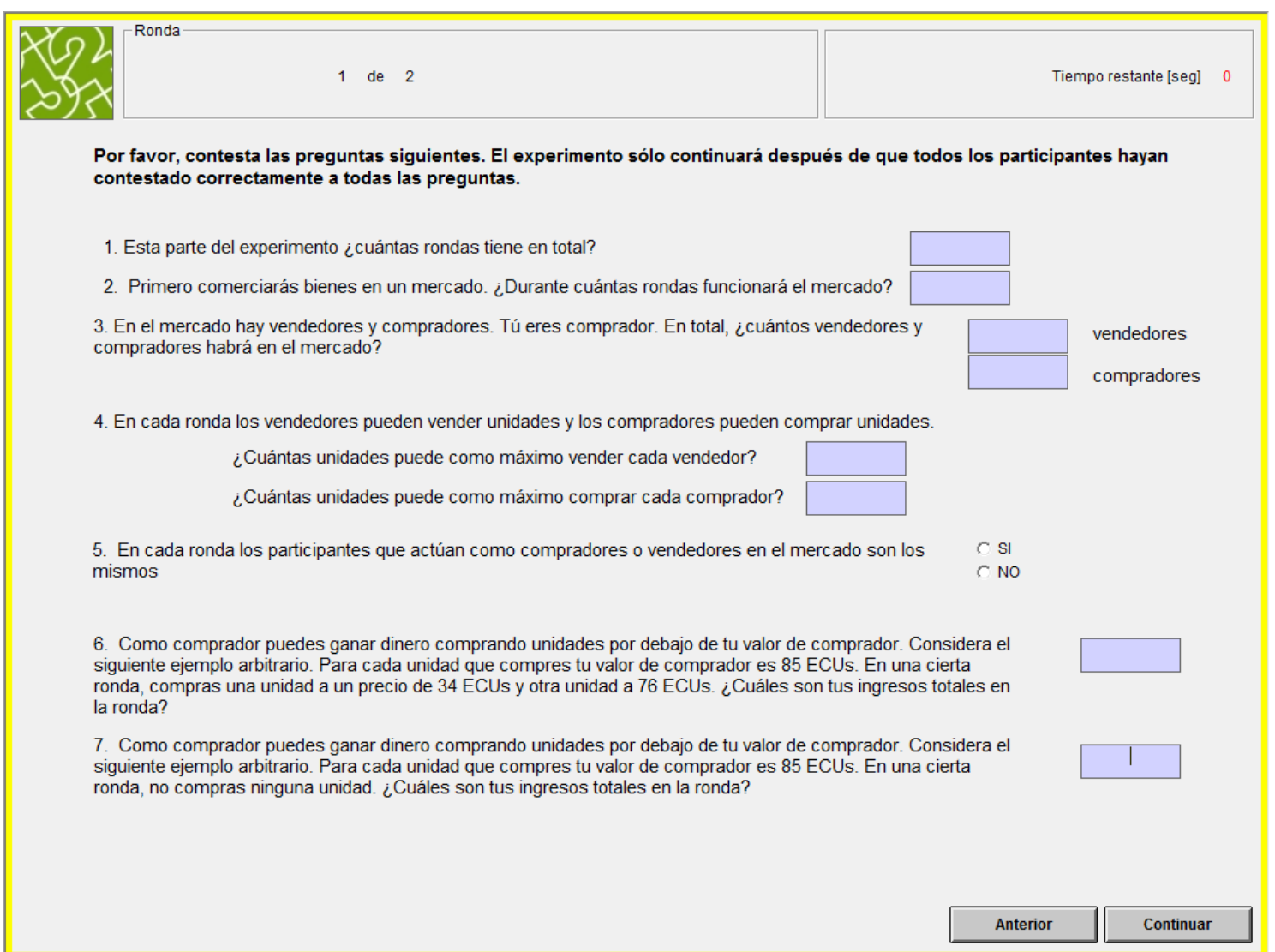

\section{Please answer the following questions. The experiment will proceed only after all participants have correctly answered all questions.}

1. This part of the experiment has in total how many rounds.

Answer: XXX rounds

2. First you will trade goods on a market. For how many rounds will the market be open?

Answer: XXX rounds

3. In the market there are sellers and buyers. You are a buyer. In total, how many sellers and buyers will be active on the market?

Answer: XXX sellers, XXX buyers

4. In each round sellers can sell units and buyers can buy units. How many units can each seller sell at most and each buyer buy at most?

Answer: $\mathrm{X}$ units

5. In each round the same participants will be active as buyers and sellers on the market?

Answer: YES NO 
6. As a buyer you can earn money by buying units at prices below your buyer value.

Consider the following arbitrary example. For each unit you buy your buyer value is 85 ECU. In a given round, you buy one unit at a price of $34 \mathrm{ECU}$ and another unit at a price of $76 \mathrm{ECU}$. What are your total earnings in that round?

\section{Answer: XX ECU}

7. As a buyer you can earn money by buying units at prices below your buyer value.

Consider the following arbitrary example. For each unit you buy your buyer value is 85

ECU. In a given round, you do not buy any unit. What are your total earnings in that round?

Answer: XX ECU 


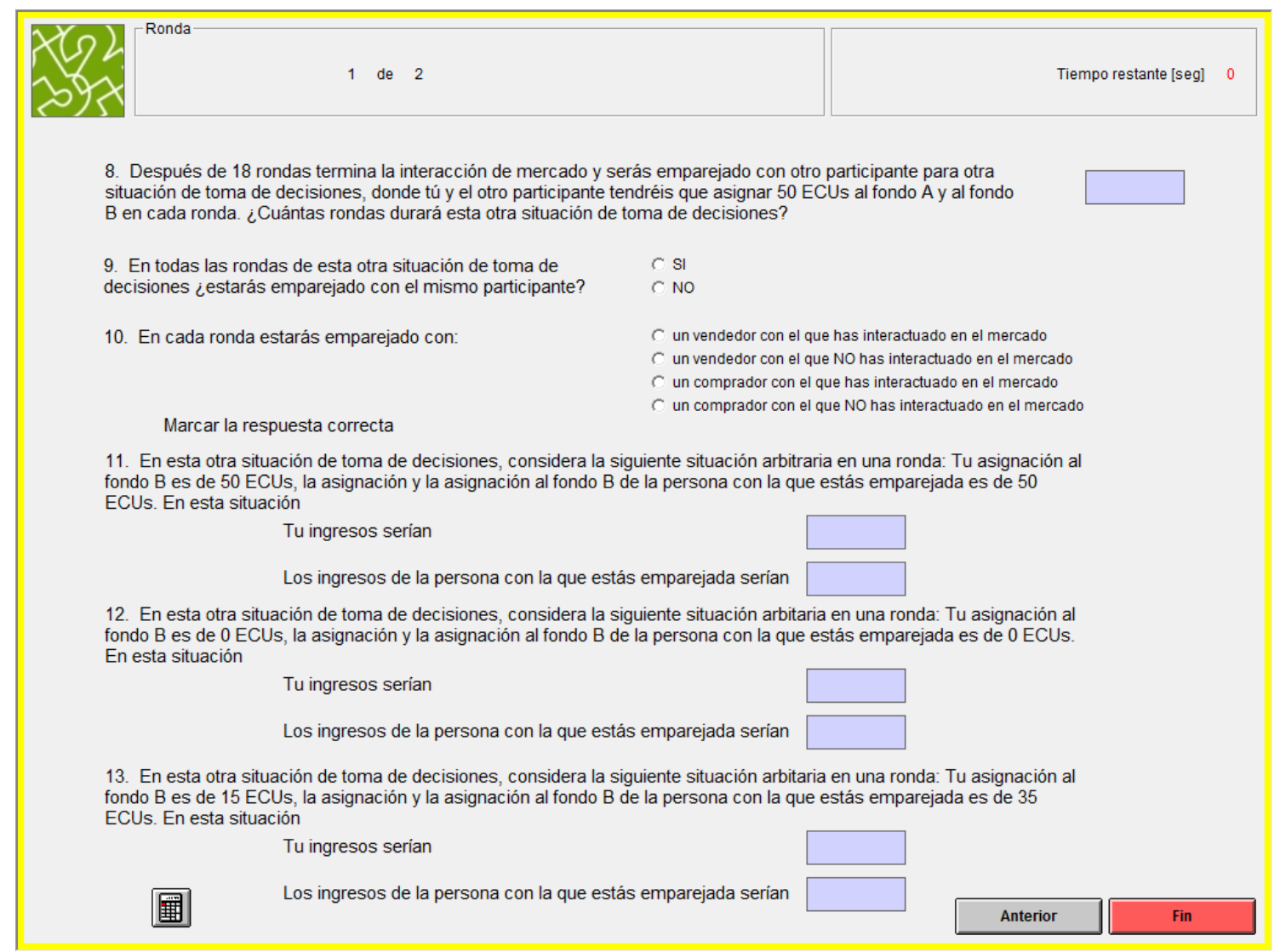

8. After 18 rounds the market interaction is over and you will be paired with one other participant for another decision making situation, where you and the other participant will have to allocate $50 \mathrm{ECU}$ to fund A and fund B in each round. How many rounds will this other decision making situation last?

\section{Answer: XX rounds}

9. In all 6 rounds of this other decision making situation you are paired with the same other participant?

\section{Answer: YES NO}

10. In each round you are paired with:

$\mathrm{O}$ a seller you have interacted with in the market

$\mathrm{O} \quad$ a seller you have NOT interacted with in the market

$\mathrm{O}$ a buyer you have interacted with in the market

$\mathrm{O}$ a buyer you have NOT interacted with in the market

(check the correct answer)

11. In this other decision making situation, Consider the following arbitrary situation in a round:

Your allocation to the fund B is $50 \mathrm{ECU}$, the allocation to fund B of the person you are 
paired with is $50 \mathrm{ECU}$.

In this situation

your earnings would be:

the earnings of the person you are paired with would be: ....

12. In this other decision making situation. Consider the following arbitrary situation in a round:

Your allocation to the fund B is $0 \mathrm{ECU}$, the allocation to fund B of the person you are paired with is $0 \mathrm{ECU}$.

In this situation

your earnings would be:

the earnings of the person you are paired with would be:

13. In this other decision making situation. Consider the following arbitrary situation in a round:

Your allocation to the fund $\mathrm{B}$ is $12 \mathrm{ECU}$, the allocation to fund $\mathrm{B}$ of the person you are paired with is $34 \mathrm{ECU}$.

In this situation

your earnings would be:

the earnings of the person you are paired with would be: .... 


\section{SELLERS}

Screen 19

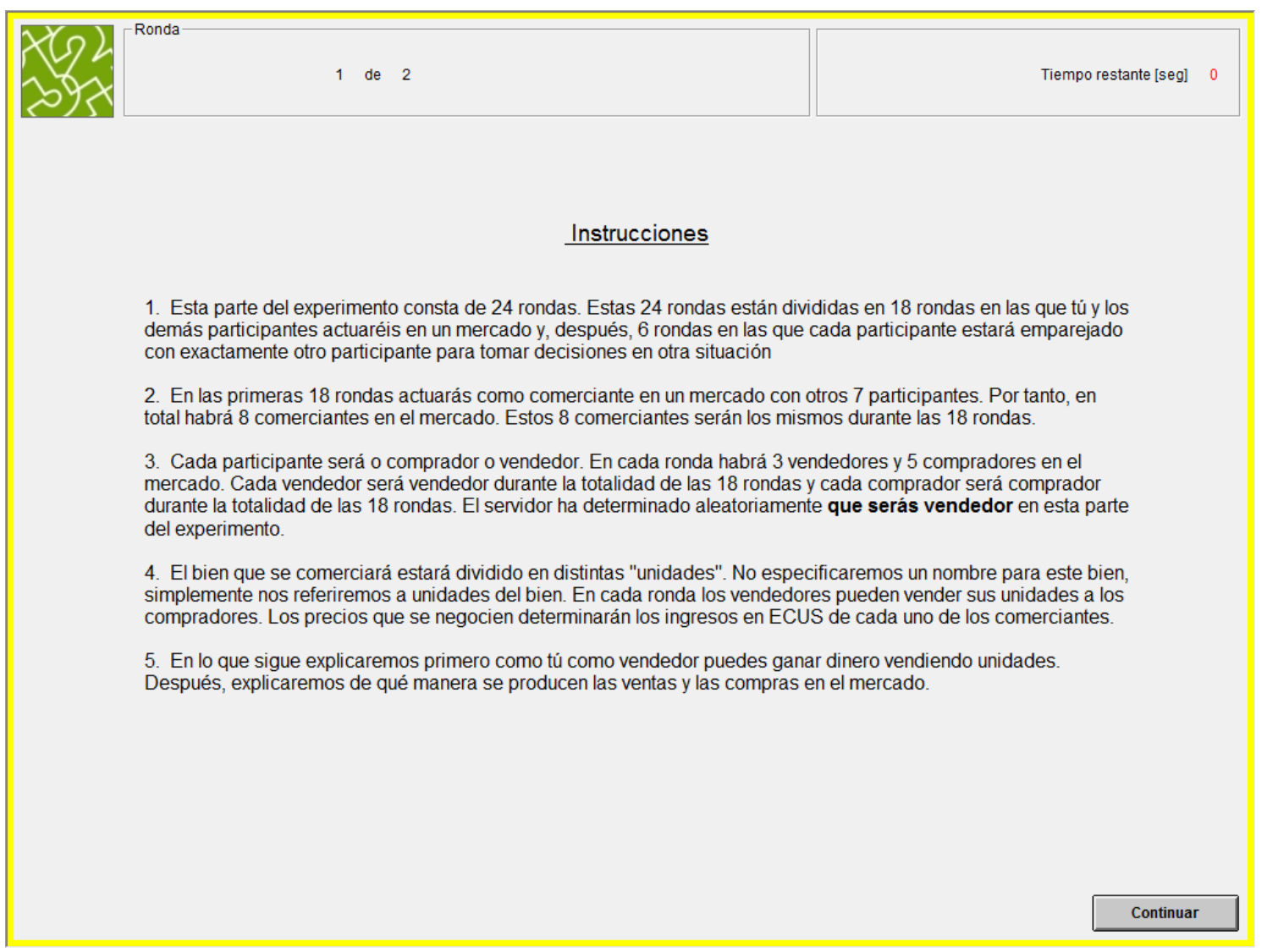

\section{Instructions}

1. This part of the experiment consists of 24 rounds. These 24 rounds are split into 18 rounds where you and the other participants will act on a market and, thereafter, 6 rounds where each participant will be paired with exactly one other participant to make allocation decisions in another situation.

2. In the first 18 rounds you will act as a trader on a market with 7 other participants. Hence, in total there will be 8 traders active on the market. These 8 traders will stay the same for all 18 rounds.

3. Each participant will be either a buyer or a seller. In each round there will be 3 sellers and 5 buyers on the market. Each seller stays a seller throughout all 18 rounds and each buyer stays a buyer for all 18 rounds. The server has randomly determined that you will be a seller in this part of the experiment.

4. The good to be traded is divided into distinct "units". We will not specify a name for the good but simply refer to units. In each round sellers can sell their units to buyers. The prices that are negotiated will determine each trader's earnings in ECUs.

5. In the following we will first explain how you as a seller can earn money through selling units. Thereafter, we will explain how sales and purchases are arranged on the market. 


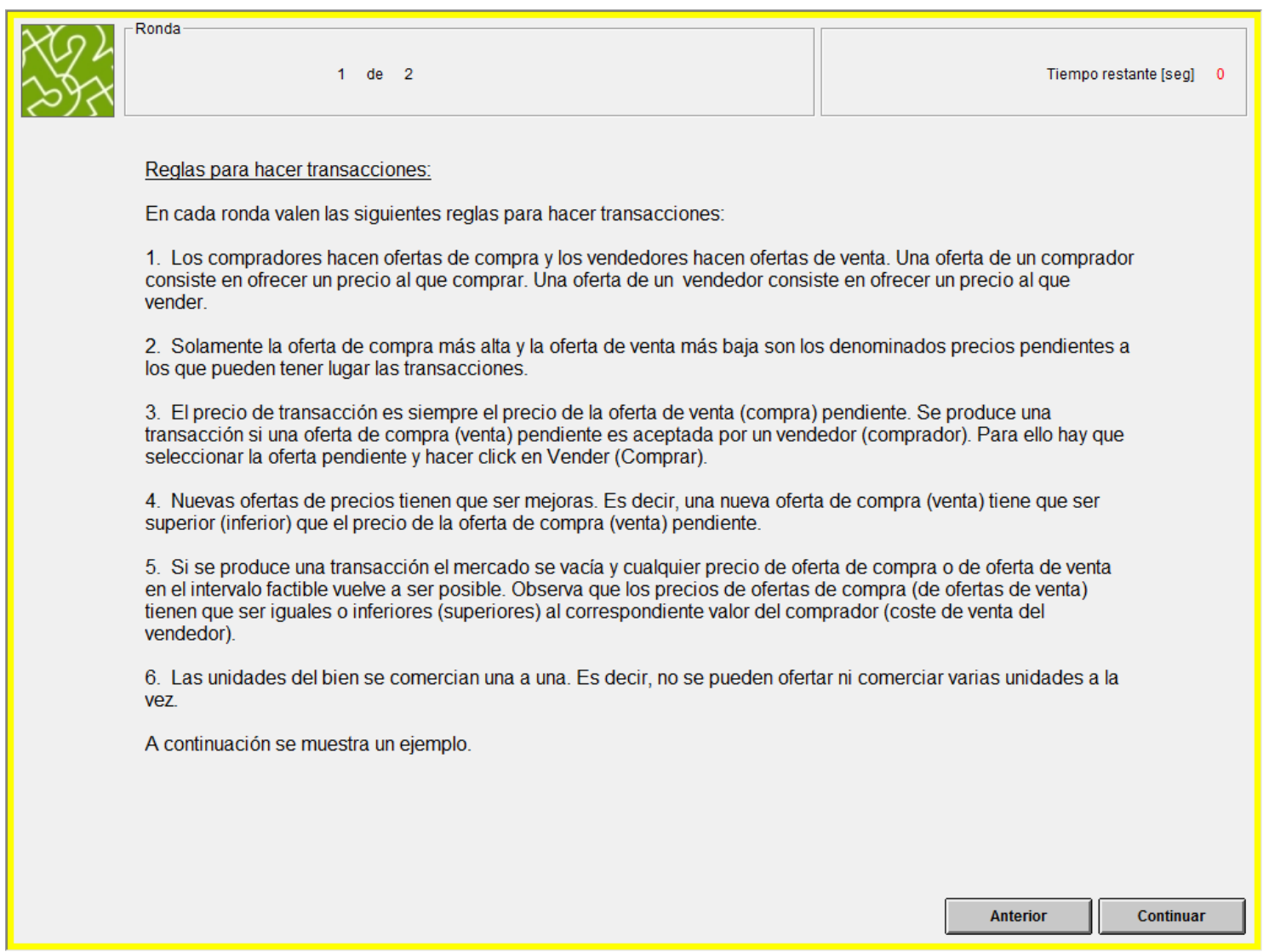

\section{$\underline{\text { Rules for making transactions }}$}

In each round there are the following rules for making transactions:

1. Buyers make buying offers and sellers make selling offers. A buying offer consists offering a price at which to purchase. A selling offer consists in offering a price at which to sell.

2. Only the highest buying offer and the lowest selling offers are the so-called standing prices at which trades can take place.

3. The transaction price is always the standing buying (selling) price. A transaction takes place if the standing buying (selling) is accepted by a seller (buyer).

4. Newly submitted price offers have to be improvements. That is, a new buying (selling) price has to be higher (lower) than the standing buying (selling) price.

5. If a transaction takes place the market clears and any buying and selling price in the feasible range are possible again. Note, that the prices of the buying offers (selling offers) bid (ask) prices have to be equal or lower (higher) than the corresponding buyer value (seller selling cost).

6. The units of the goods are traded one by one. That is, it is not possible to offer or exchange several units at the same time.

In what follows we show you an example. 


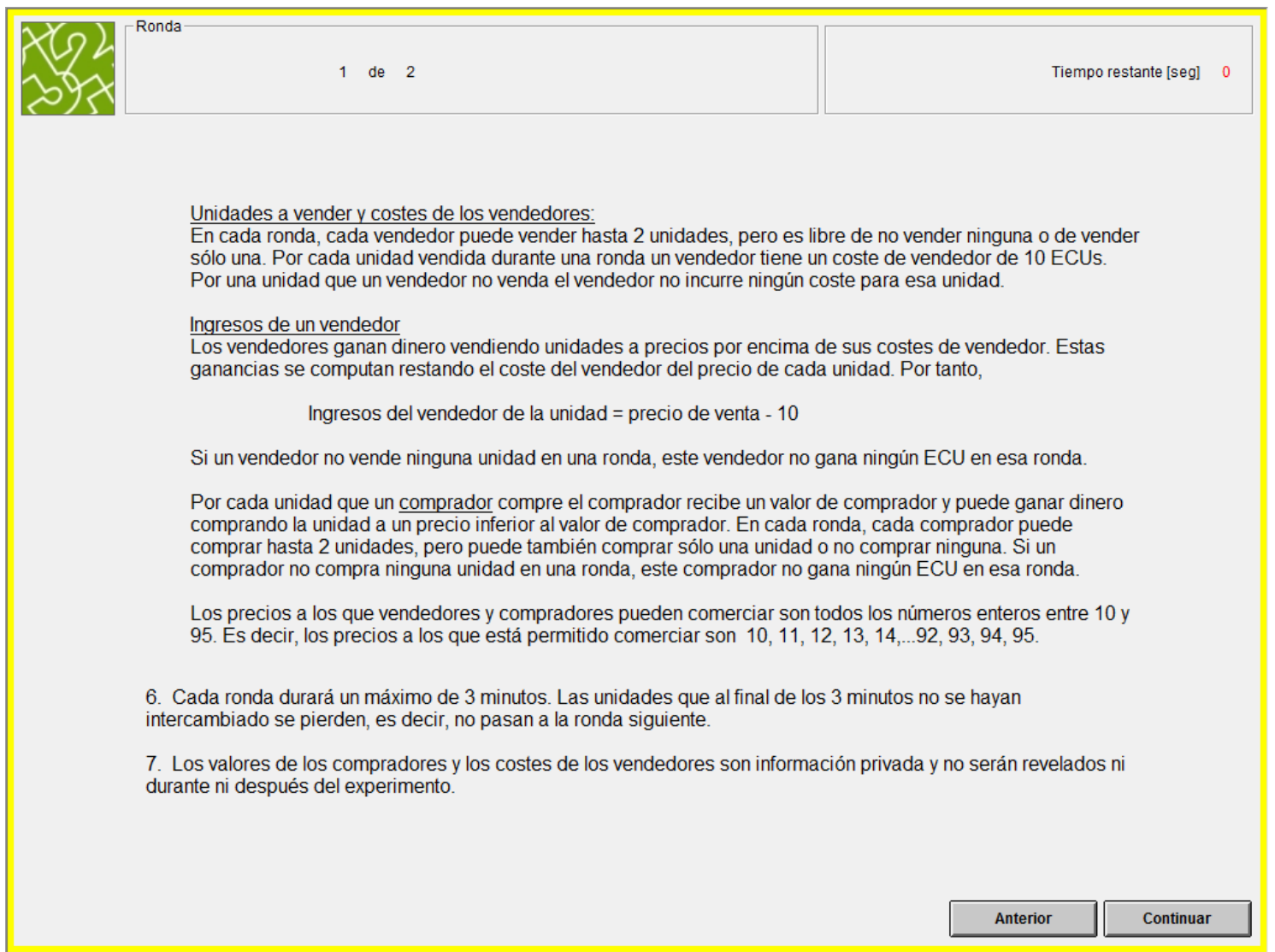

Units to sell and seller costs:

In each round, each seller can sell at most 2 units, but is free to sell no units or only one unit. For each unit sold during a round a seller incurs costs of 10 ECUs. For a unit a seller does not sell the seller does not incur the costs for that unit.

\section{Seller earnings:}

Sellers make profits by selling units at prices that are above their costs. These profits are computed by subtracting each unit's costs from its selling price. Therefore,

$$
\text { seller's earnings per unit }=\text { selling price for unit }-10 \text {. }
$$

If a seller does not sell any unit in a round, this seller does not earn any ECU's in this round.

For each unit a buyer purchases, the buyer receives a buyer value and can earn money by purchasing the unit at a price lower than the buyer value. In each round, each buyer can purchase at most 2 units, but may also purchase no units or only one unit. If a buyer does not purchase any unit in a round, this buyer does not earn any ECU's in this round.

The prices at which sellers and buyers are allowed to trade are all inter numbers between 10 and 95. That is the permitted trading prices are $\{10,11,12,13,14, \ldots, 92,93,94,95\}$.

6. Each round will last for a maximum of 3 minutes. The units that at the end of the 3 minutes have not been sold are lost, that is, they are not carried over to the next round.

7.Buyer values and seller costs are private information and will not be revealed neither during nor after the experiment. 
Screen 22

This is the screen a buyer faces when making and accepting offers in a round, which is explained on the next screen.

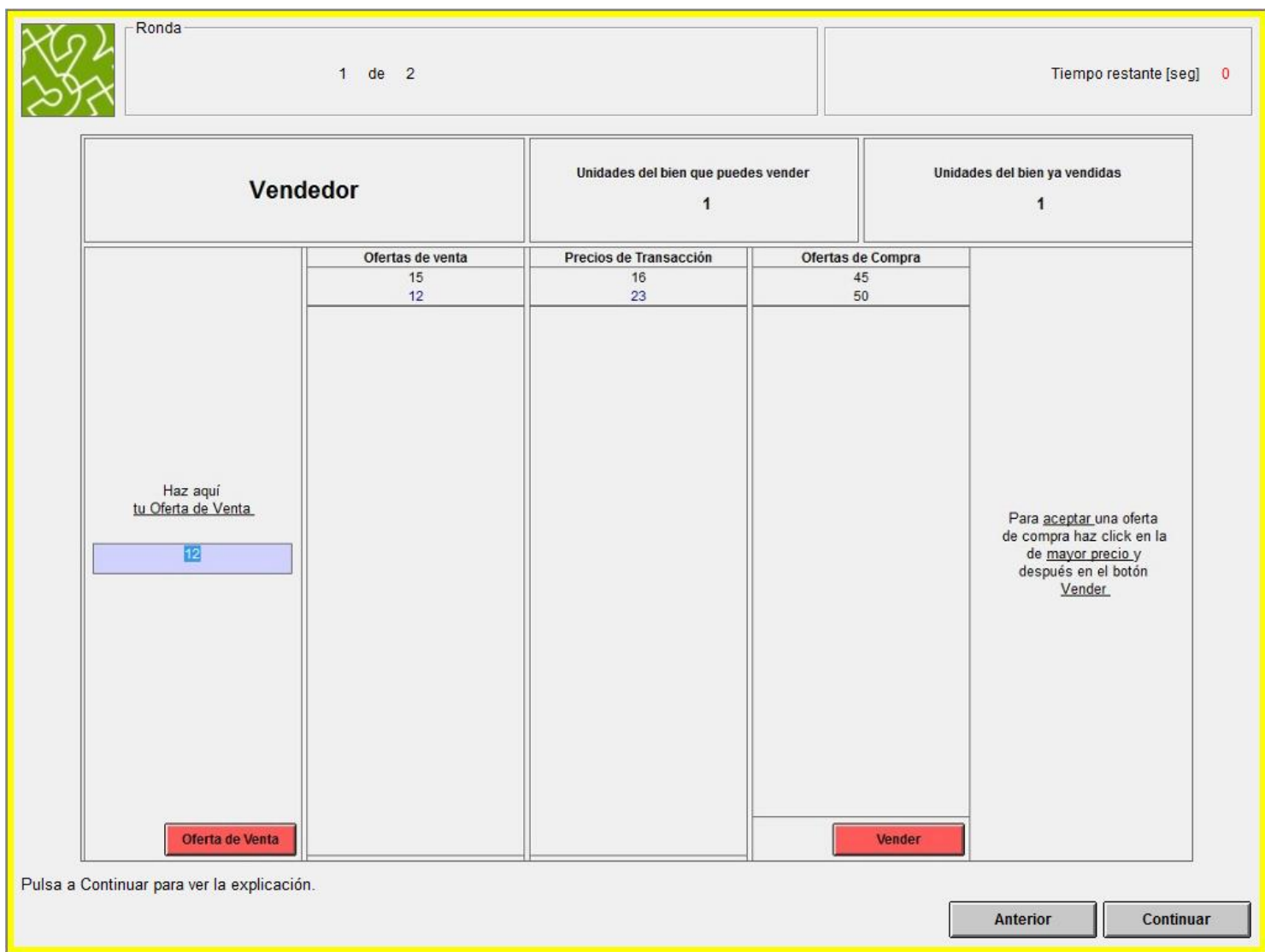




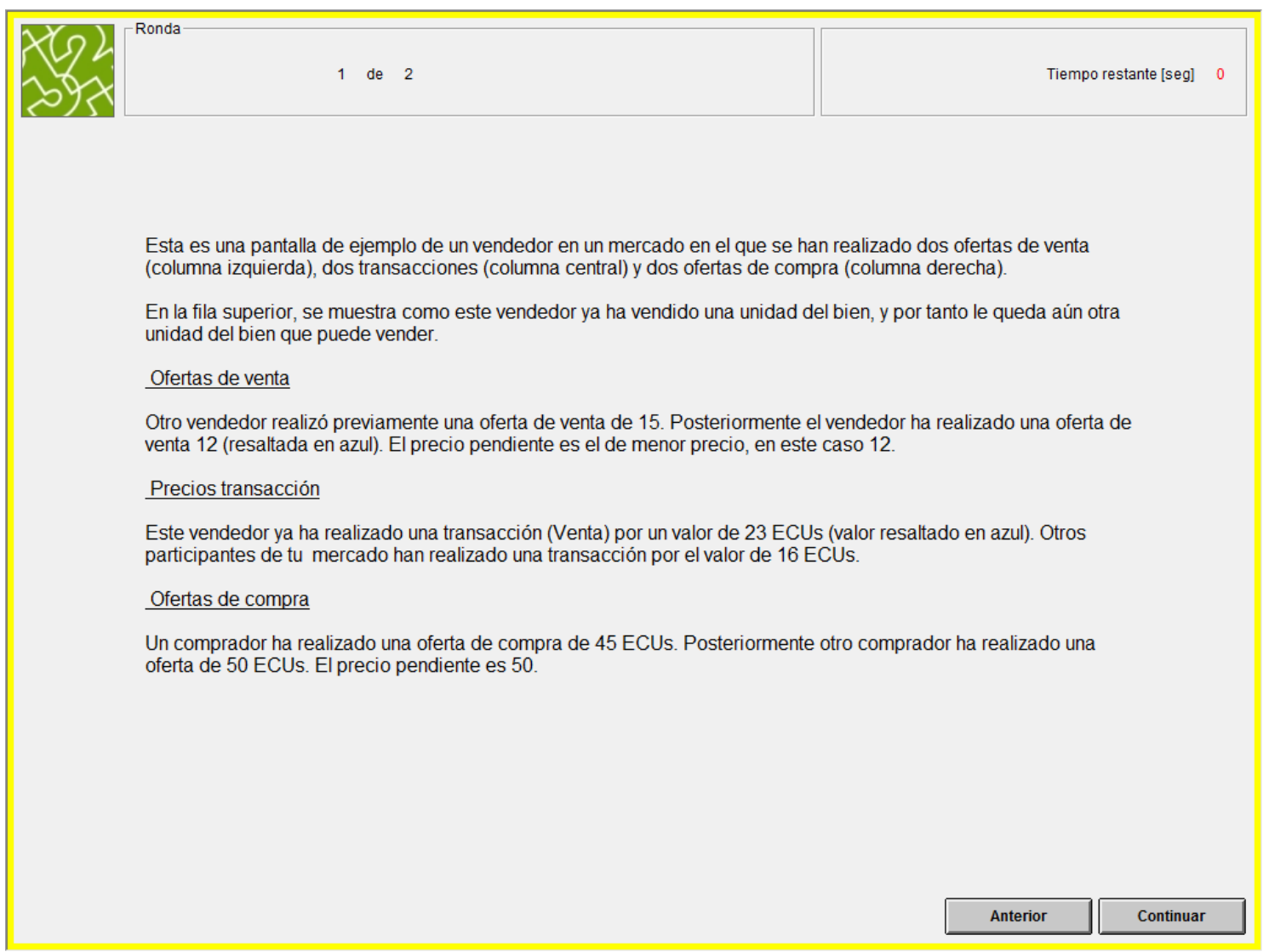

This is an example screen of a seller in a market in which two selling offers (left column), two transactions (central column) and two buying offers (right column) have been made.

In the top row, it is shown that this seller has already purchased one unit of the good, and therefore he still can sell one other unit.

\section{$\underline{\text { Selling offers }}$}

Another seller has made a selling offer of 15. After this seller has made a selling offer of 12 (highlighted in blue). The standing price is the lower price, in this case 12.

\section{$\underline{\text { Transaction prices }}$}

This seller has already made one transaction (sale) for a value of 23 ECUs (value shown in blue). Other participants of your market have made a transaction for a value of 16 ECUs.

\section{$\underline{\text { Buying offers }}$}

Another buyer has made a buying offer of 45 ECUs. After that another buyer has made an offer of 50 ECUs. The standing price is 50 . 
Screen 24

This screen is the same than screen 22, but with the highlighted items mentioned on screen 23.

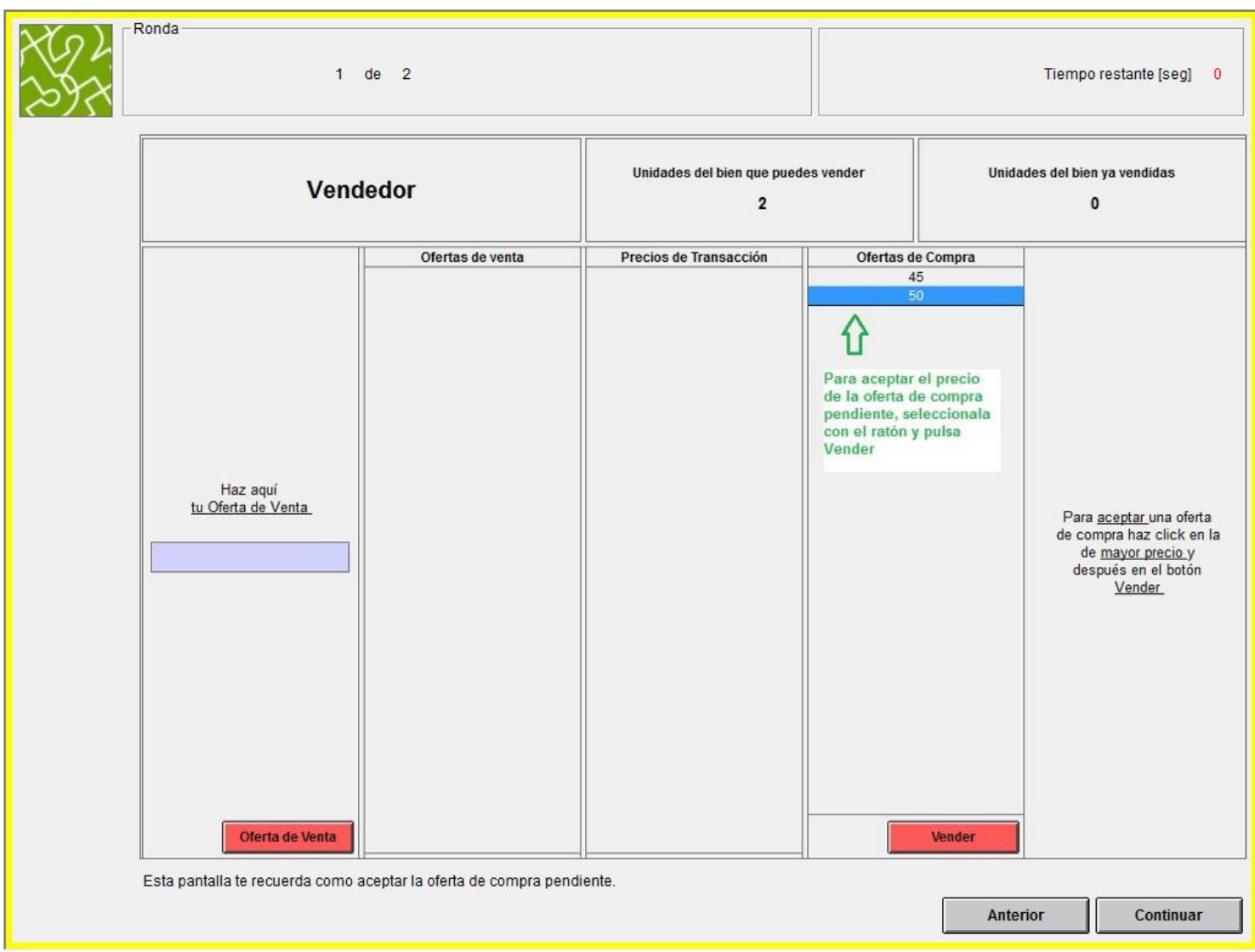


Screen 25

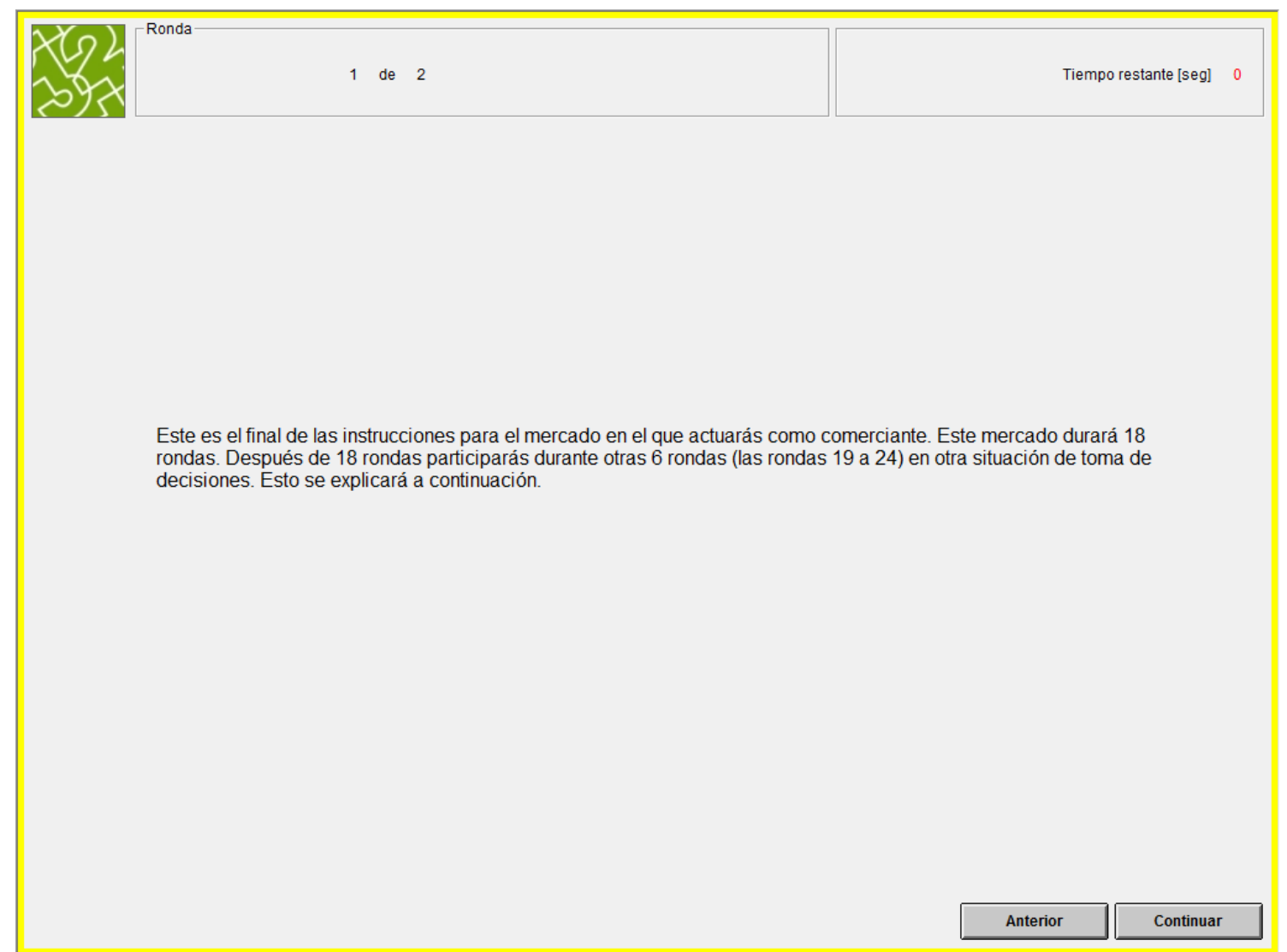

This is the end of the instructions for the market where you will act as a trader. This market will last for 18 rounds. After 18 rounds you will participate for another 6 rounds (rounds 19 to 24) in another decision making situation. This will be explained below. 


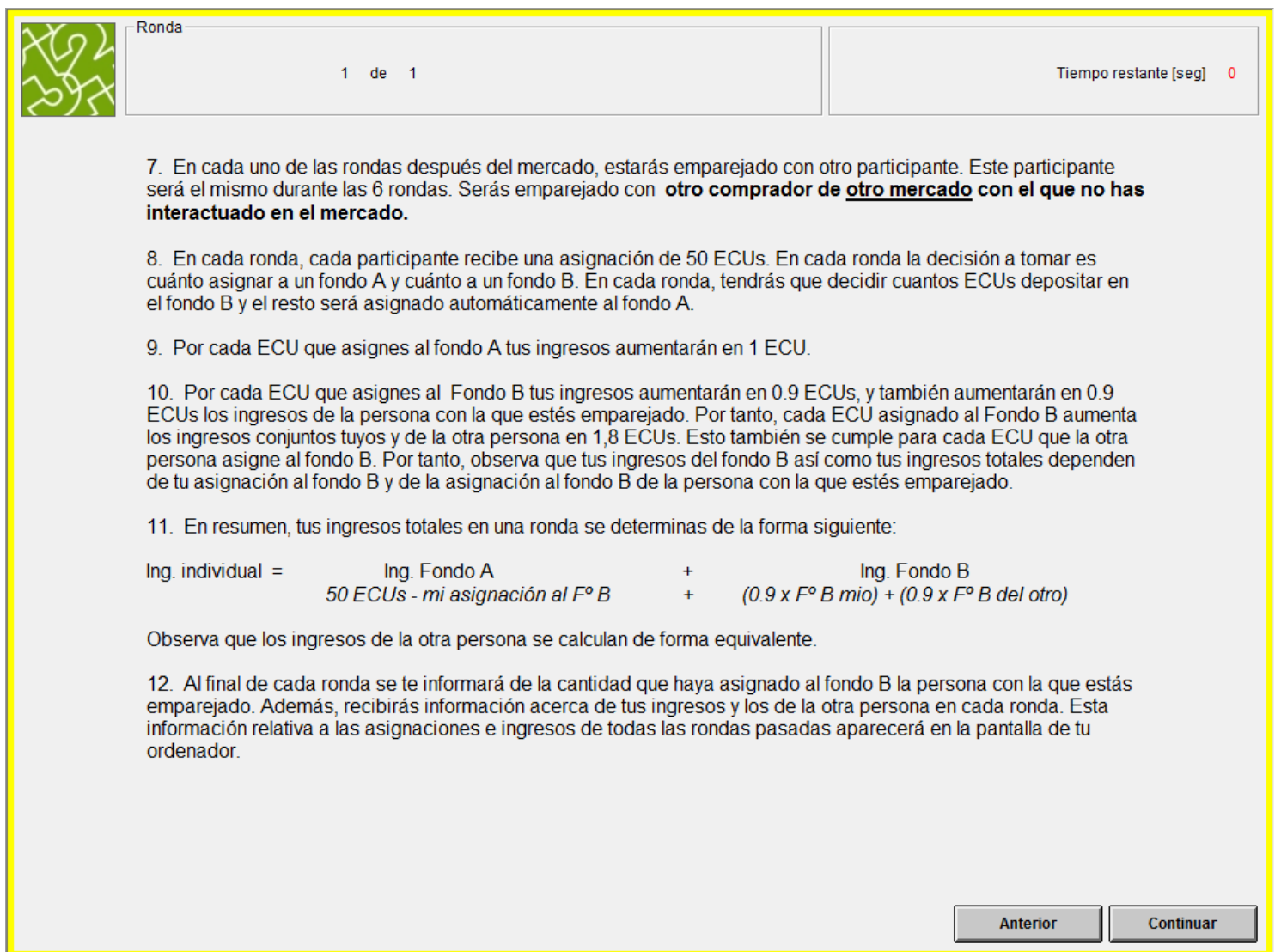

7.In each of the rounds that follow the market, you are paired with one other participants. This other participant will be the same throughout these 6 rounds. You will be paired with another buyer from another market with whom you have not interacted in the market.

8. In each round, each participant receives an endowment of 50 ECUs. In each round the decision to be made is to choose how much you allocate to a Fund A and to a Fund B. In each round, you will have to decide how many ECUs to deposit in fund B and the rest will be allocated to fund A automatically.

9.For each ECU that you allocate to fund A your earnings will increase by 1 ECU.

10.For each ECU that you allocate to fund B, your earnings will increase by 0.9 ECUs, and also the earnings of the other person you are paired with will increase by 0.9 ECUs. Hence, each ECU allocated to fund B increases your and the other's earnings together with 1.8 ECU. This also holds for each ECU the other person allocates to fund B. Hence, note that your earnings from fund B as well as your total earnings, depend on your allocation to fund B and on the allocation to fund B of the person you are paired with.

11.In summary, your total earning in one round are determined in the following way:

Individual earnings Earnings fund $\mathrm{A}+\quad$ Earnings fund $\mathrm{B}$

$=$

$$
\begin{aligned}
50 \text { ECU - my allocation to fund } B+\begin{array}{l}
(0.9 \times \text { my allocation to fund } B) \\
+(0.9 x \text { other person's } \\
\text { allocation to fund } B)
\end{array}
\end{aligned}
$$

Note, that the earnings of the other person are calculated in an equivalent way.

12. At the end of each round, you will be informed of the allocation to fund B of the person you are paired with. Moreover, you will receive information on your and the other person's earnings in each round. This information regarding the allocation and earnings of all previous rounds will appear on your computer screen. 


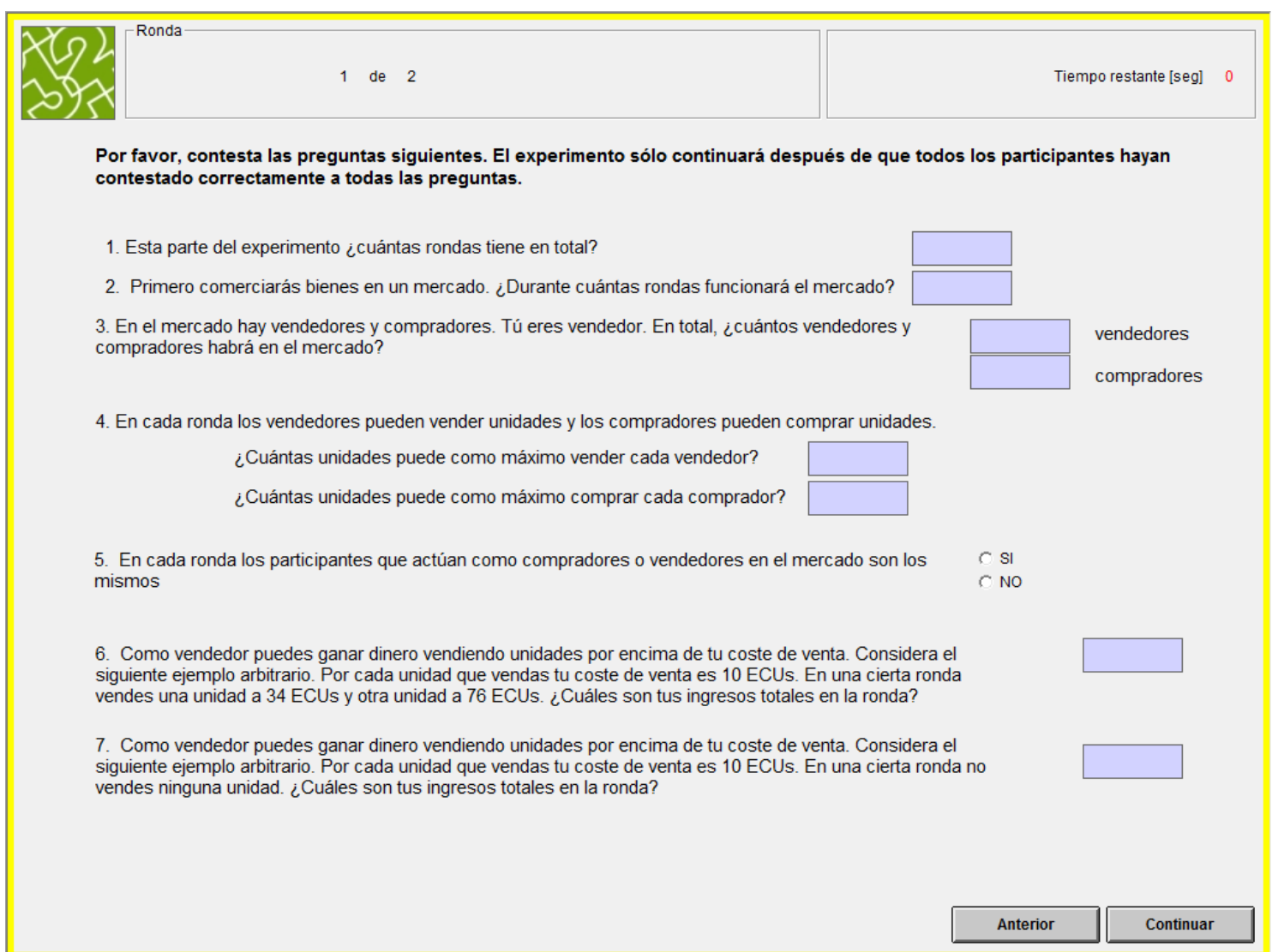

\section{Please answer the following questions. The experiment will proceed only after all participants have correctly answered all questions.}

1. This part of the experiment has in total how many rounds.

Answer: XXX rounds

2. First you will trade goods on a market. For how many rounds will the market be open?

Answer: XXX rounds

3. In the market there are sellers and buyers. You are a buyer. In total, how many sellers and buyers will be active on the market?

Answer: XXX sellers, XXX buyers

4. In each round sellers can sell units and buyers can buy units. How many units can each seller sell at most and each buyer buy at most?

Answer: $\mathrm{X}$ units

5. In each round the same participants will be active as buyers and sellers on the market?

Answer: YES NO 
6. As a buyer you can earn money by buying units at prices below your buyer value.

Consider the following arbitrary example. For each unit you buy your buyer value is 85 ECU. In a given round, you buy one unit at a price of 34 ECU and another unit at a price of $76 \mathrm{ECU}$. What are your total earnings in that round?

Answer: XX ECU

7. As a buyer you can earn money by buying units at prices below your buyer value.

Consider the following arbitrary example. For each unit you buy your buyer value is 85 ECU. In a given round, you do not buy any unit. What are your total earnings in that round?

Answer: XX ECU 


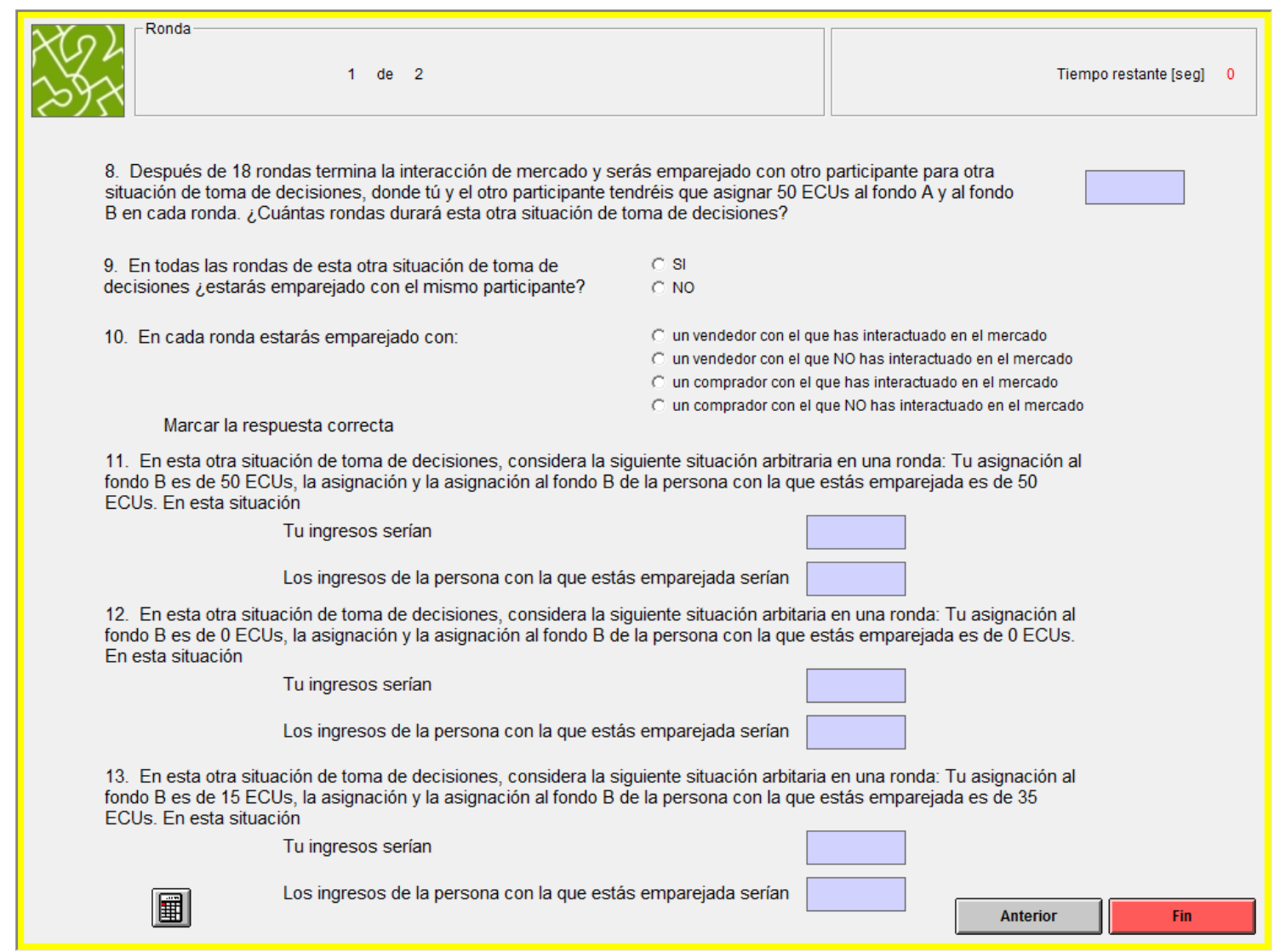

8. After 18 rounds the market interaction is over and you will be paired with one other participant for another decision making situation, where you and the other participant will have to allocate $50 \mathrm{ECU}$ to fund A and fund B in each round. How many rounds will this other decision making situation last?

\section{Answer: XX rounds}

9. In all 6 rounds of this other decision making situation you are paired with the same other participant?

\section{Answer: YES NO}

10. In each round you are paired with:

$\mathrm{O}$ a seller you have interacted with in the market

$\mathrm{O} \quad$ a seller you have NOT interacted with in the market

$\mathrm{O}$ a buyer you have interacted with in the market

$\mathrm{O}$ a buyer you have NOT interacted with in the market

(check the correct answer)

11. In this other decision making situation, Consider the following arbitrary situation in a round:

Your allocation to the fund B is $50 \mathrm{ECU}$, the allocation to fund B of the person you are 
paired with is $50 \mathrm{ECU}$.

In this situation

your earnings would be:

the earnings of the person you are paired with would be: ...

12. In this other decision making situation. Consider the following arbitrary situation in a round:

Your allocation to the fund B is $0 \mathrm{ECU}$, the allocation to fund B of the person you are paired with is $0 \mathrm{ECU}$.

In this situation

your earnings would be:

the earnings of the person you are paired with would be:

13. In this other decision making situation. Consider the following arbitrary situation in a round:

Your allocation to the fund $\mathrm{B}$ is $12 \mathrm{ECU}$, the allocation to fund $\mathrm{B}$ of the person you are paired with is $34 \mathrm{ECU}$.

In this situation

your earnings would be:

the earnings of the person you are paired with would be: .... 
SELLERS AND BUYERS

(These screens are the ones the participants see during the experiment).

\begin{tabular}{|c|c|c|c|c|}
\hline & 1 de 2 & & $X(\Omega)$ Ronda & Tiempo restante [seg] 177 \\
\hline \multicolumn{2}{|c|}{ Vendedor } & \multicolumn{2}{|c|}{$\begin{array}{l}\text { Unidades del bien que puedes vender } \\
2\end{array}$} & $\begin{array}{c}\text { Unidades del bien ya vendidas } \\
0\end{array}$ \\
\hline & Ofertas de venta & $\begin{array}{l}\text { Precios de Transacción } \\
\end{array}$ & & \\
\hline $\begin{array}{c}\begin{array}{c}\text { Haz aquí } \\
\text { tu Oferta de Venta }\end{array} \\
\end{array}$ & & & & $\begin{array}{l}\text { Para aceptarar una oferta } \\
\text { de compra haz click en Ia } \\
\text { de mayor precioy } \\
\text { despuesen en botóñ } \\
\text { vender }\end{array}$ \\
\hline Oferta de Vente & & & & \\
\hline
\end{tabular}


Screen 29

This screen shows the transaction screen of a seller at the beginning of a round.

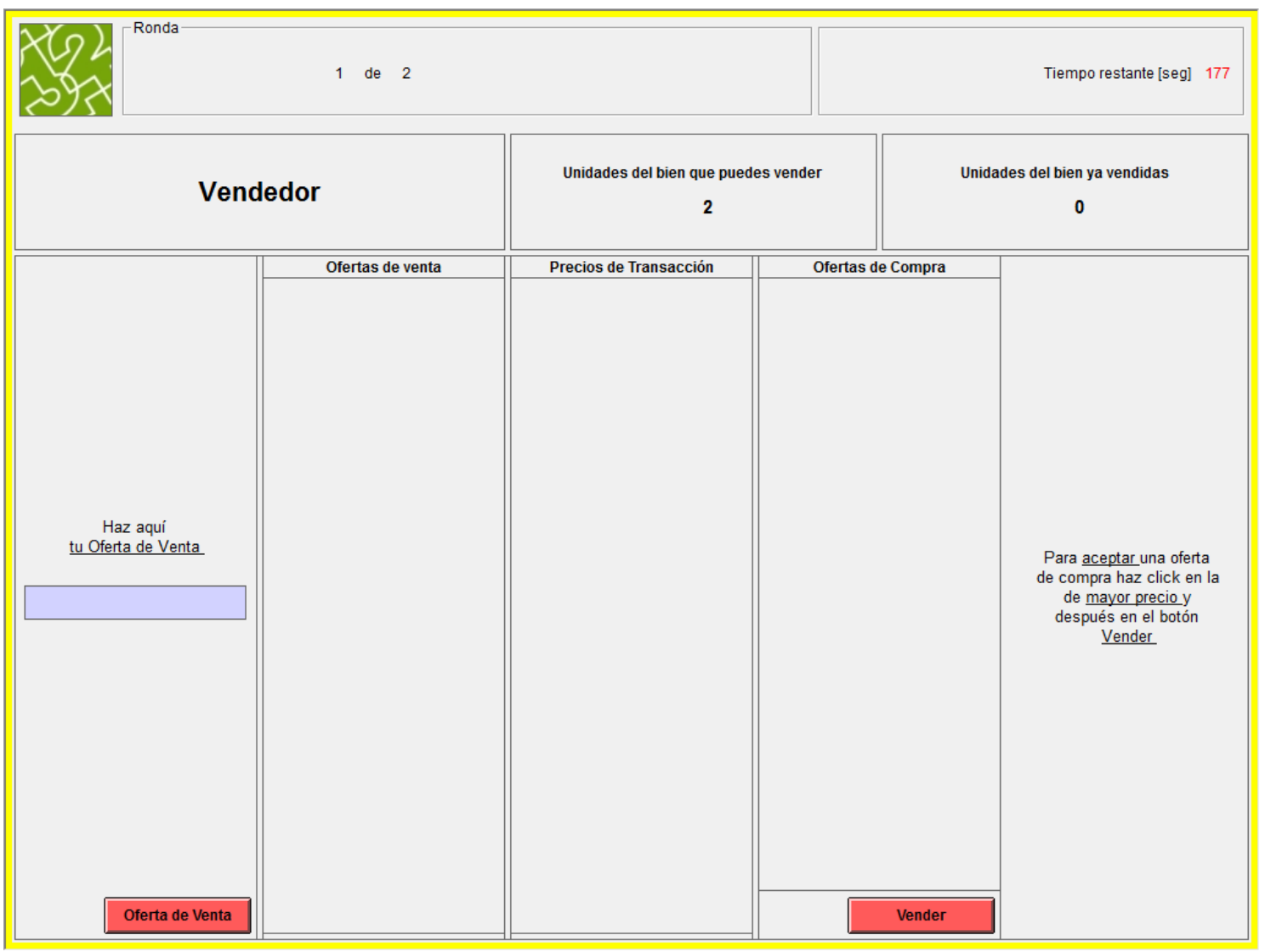


Screen 30

This screen shows the transaction screen of a buyer at the beginning of a round.

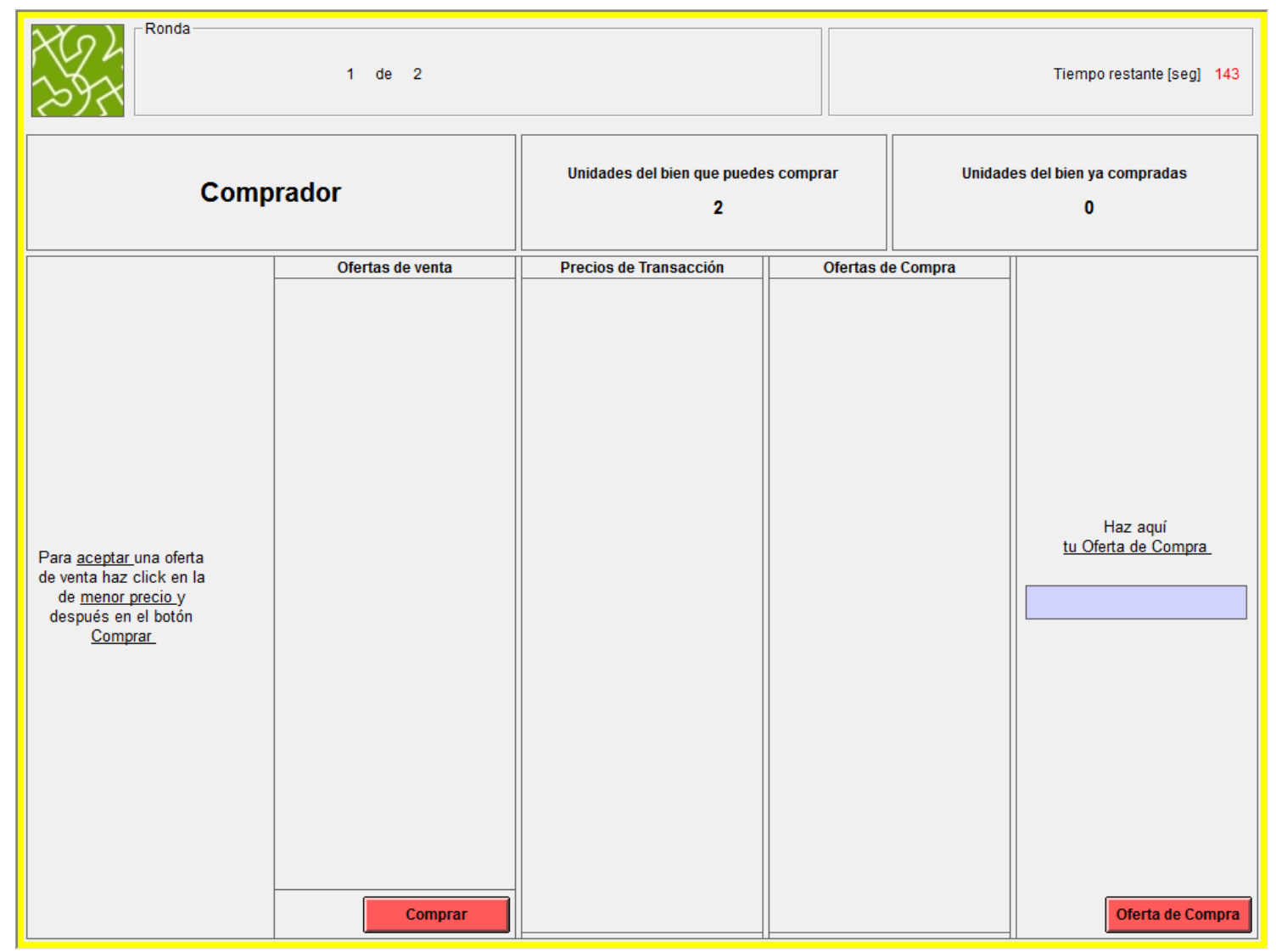


Screen 31

Se han hecho todas las transacciones posibles en el mercado

All the possible market transactions have been made. 
Screen 32

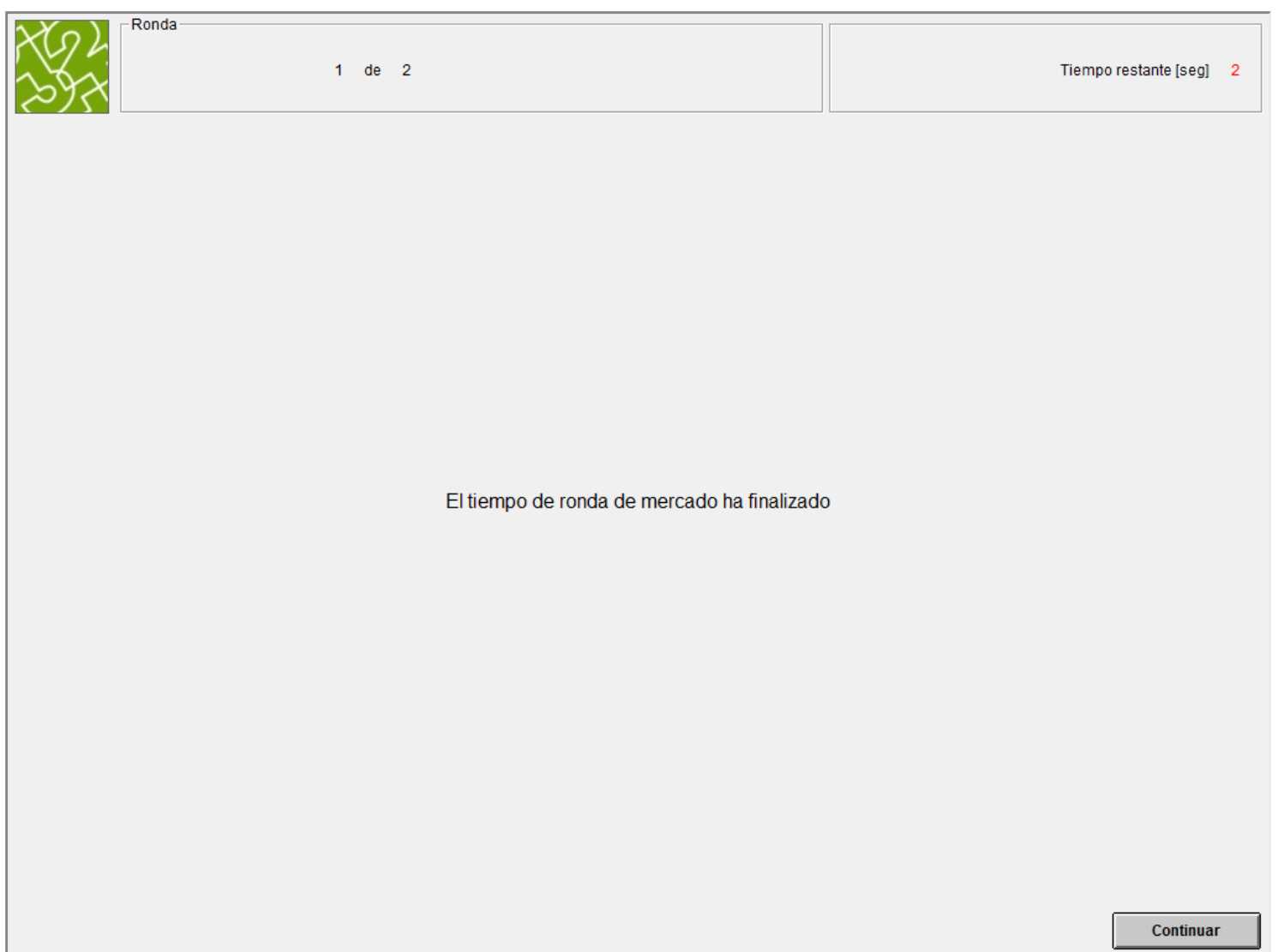

The time of the market round is over. 
Screen 33

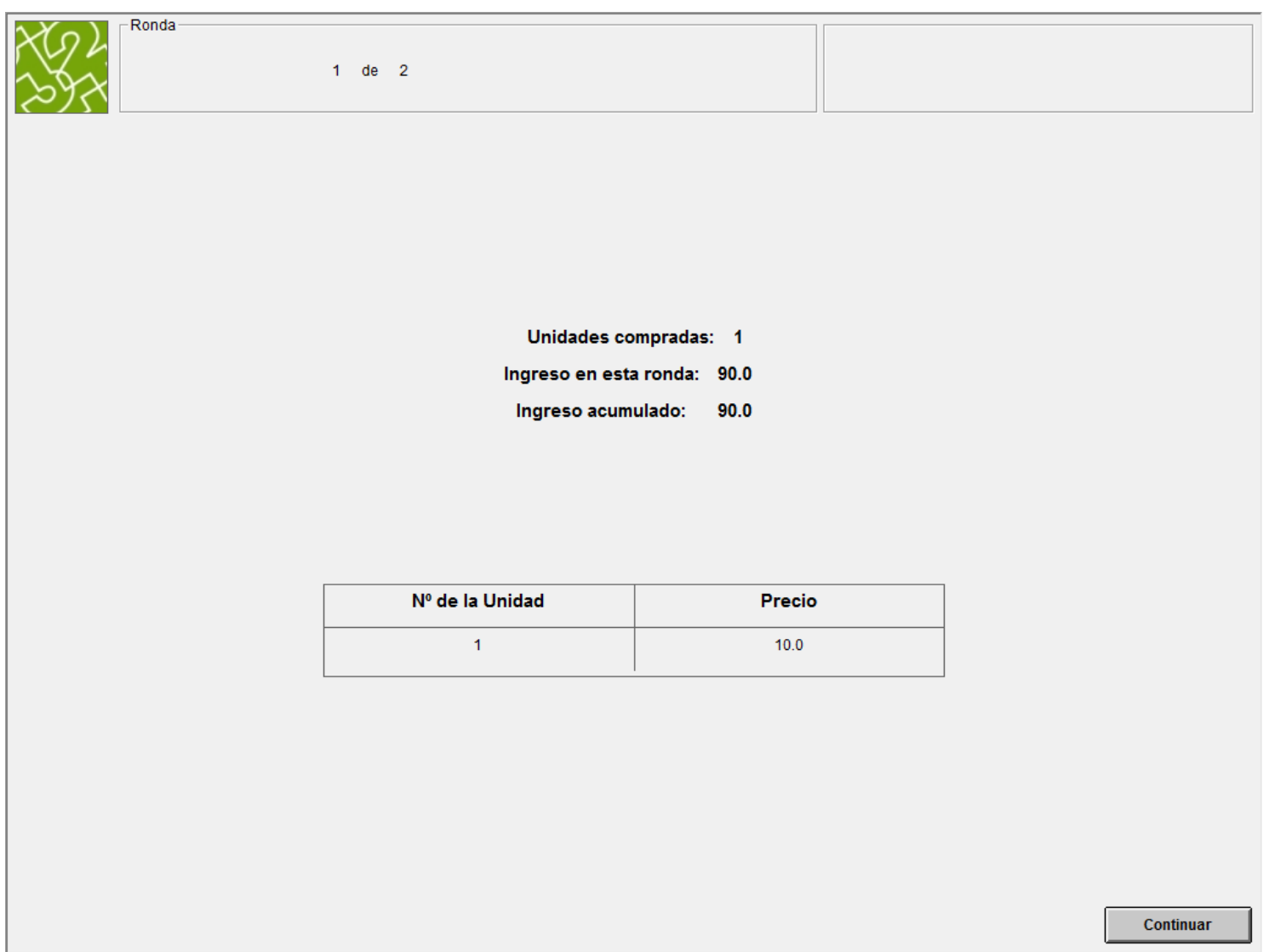

Purchased units: 1

Earnings in this round: 90

Accumulated earnings: 90

Number of unit: 1, Price: 10 
Esta ha sido la última ronda del Mercado. Ahora participarás durante otras 6 rondas (rondas 19 a 24) en la otra situación de toma de decisiones mencionada en las instrucciones.

This has been the last market round. Now you will participate for another 6 rounds (rounds 19 to 24 ) in the other decision making situation mentioned in the instructions. 
Screen 35

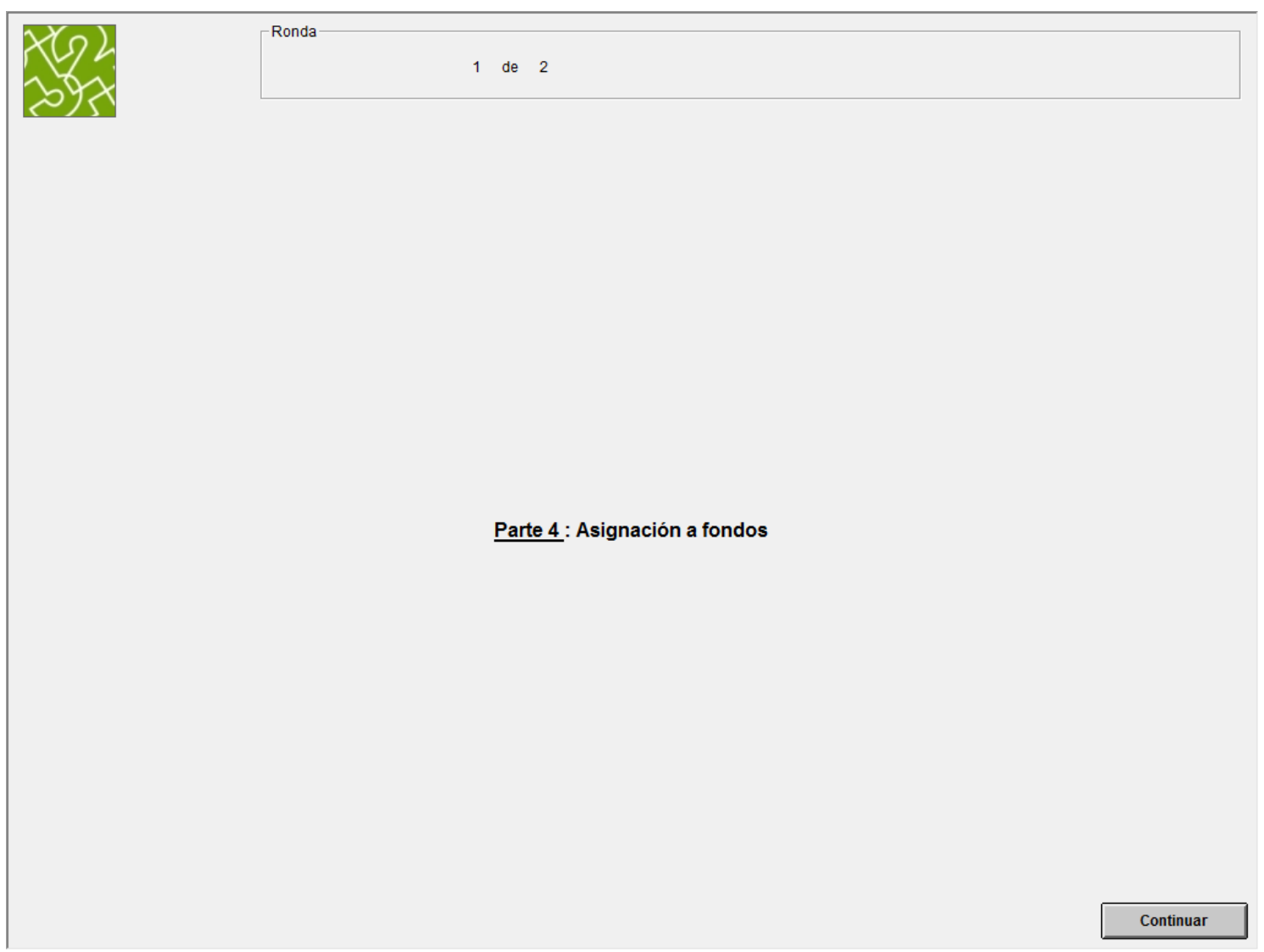

Part 4: Allocation to funds 


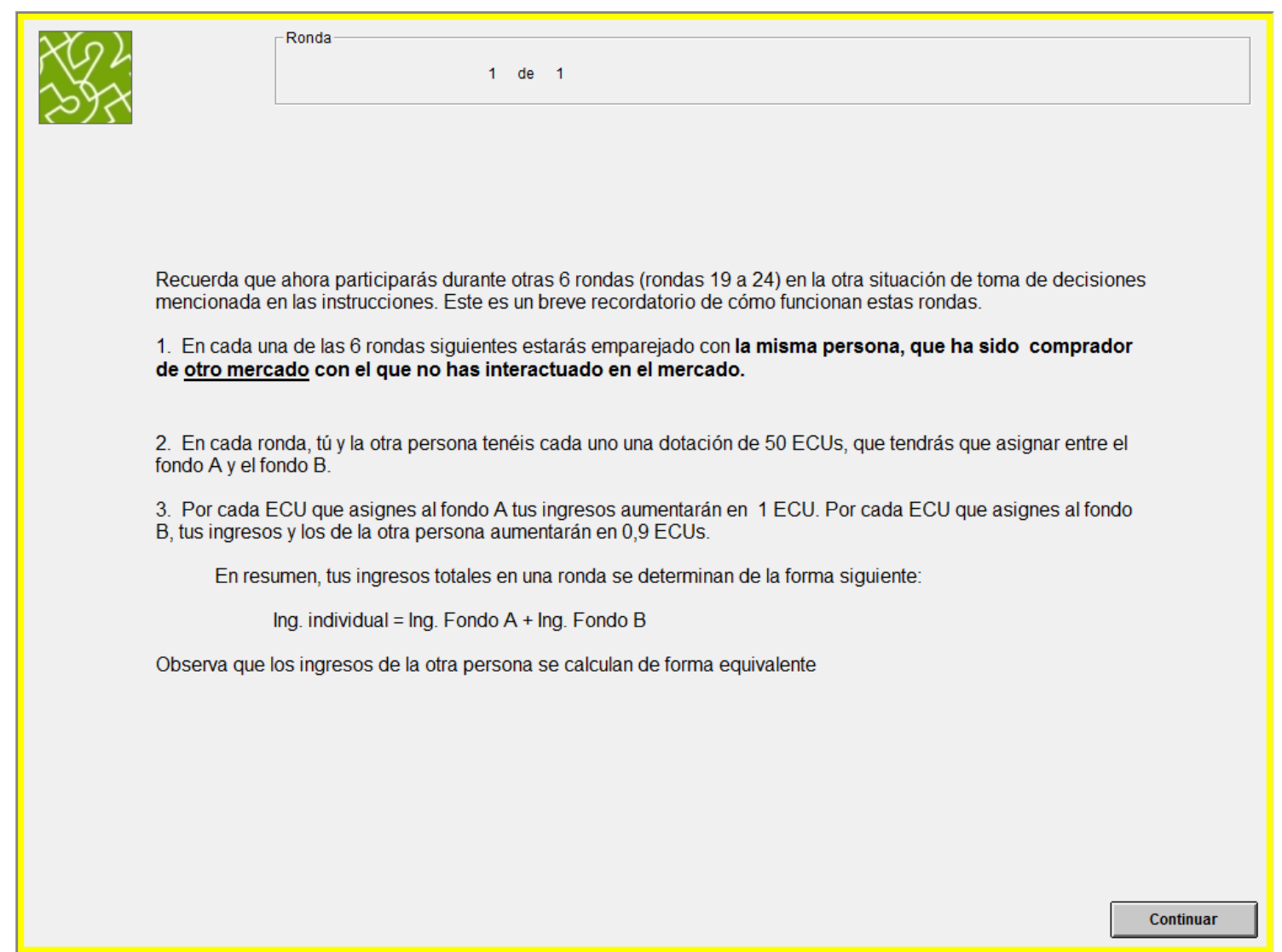

Remember that you will now participate during 6 rounds (rounds 19 to 24) in the other decision making situation mentioned in the introduction. This is a brief reminder of these rounds work.

1. In each of the 6 rounds, you are paired with the same person, who has been a buyer of the other market with whom you have not interacted in the market.

2. In each round, you and the other person receive an endowment of 50 ECUs, which you will have to allocate between the fund $\mathrm{A}$ and the fund $\mathrm{B}$.

3. For each ECU that you allocate to fund A your earnings will increase by $1 \mathrm{ECU}$. For each ECU that you allocate to fund B, your earnings and the earnings of the other person will increase by 0.9 ECUs.

In summary, your total earnings in a round are determined in the following way:

$$
\text { Individual earnings }=\text { Earnings from fund } \mathrm{A}+\text { Earnings from fund } \mathrm{B}
$$

Observe that the earnings of the other person are calculated in an equivalent way 
Screen 37

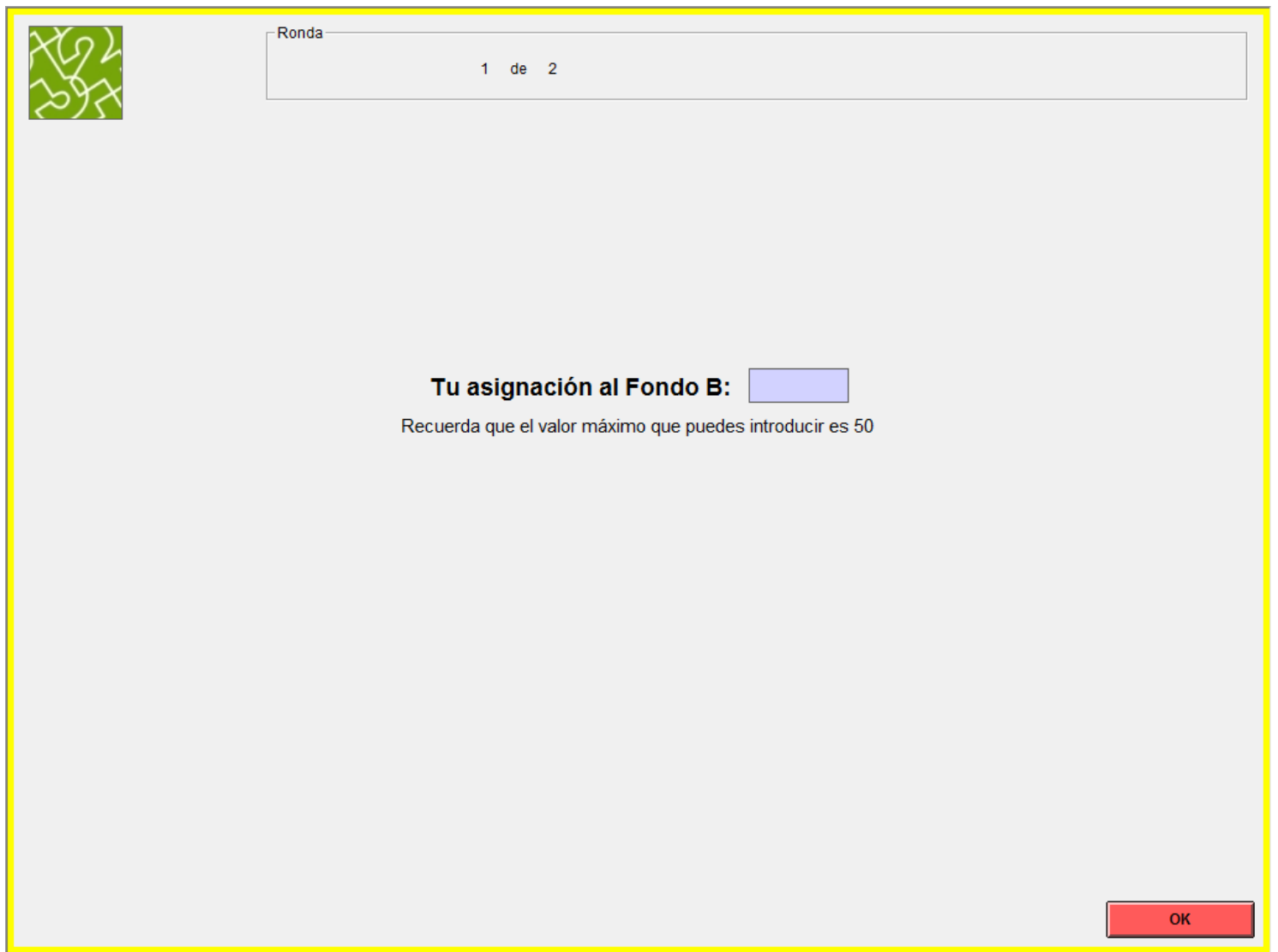

Your assignment to Fund B:

Remember that the maximum value that you can introduce is 50 . 
Screen 38

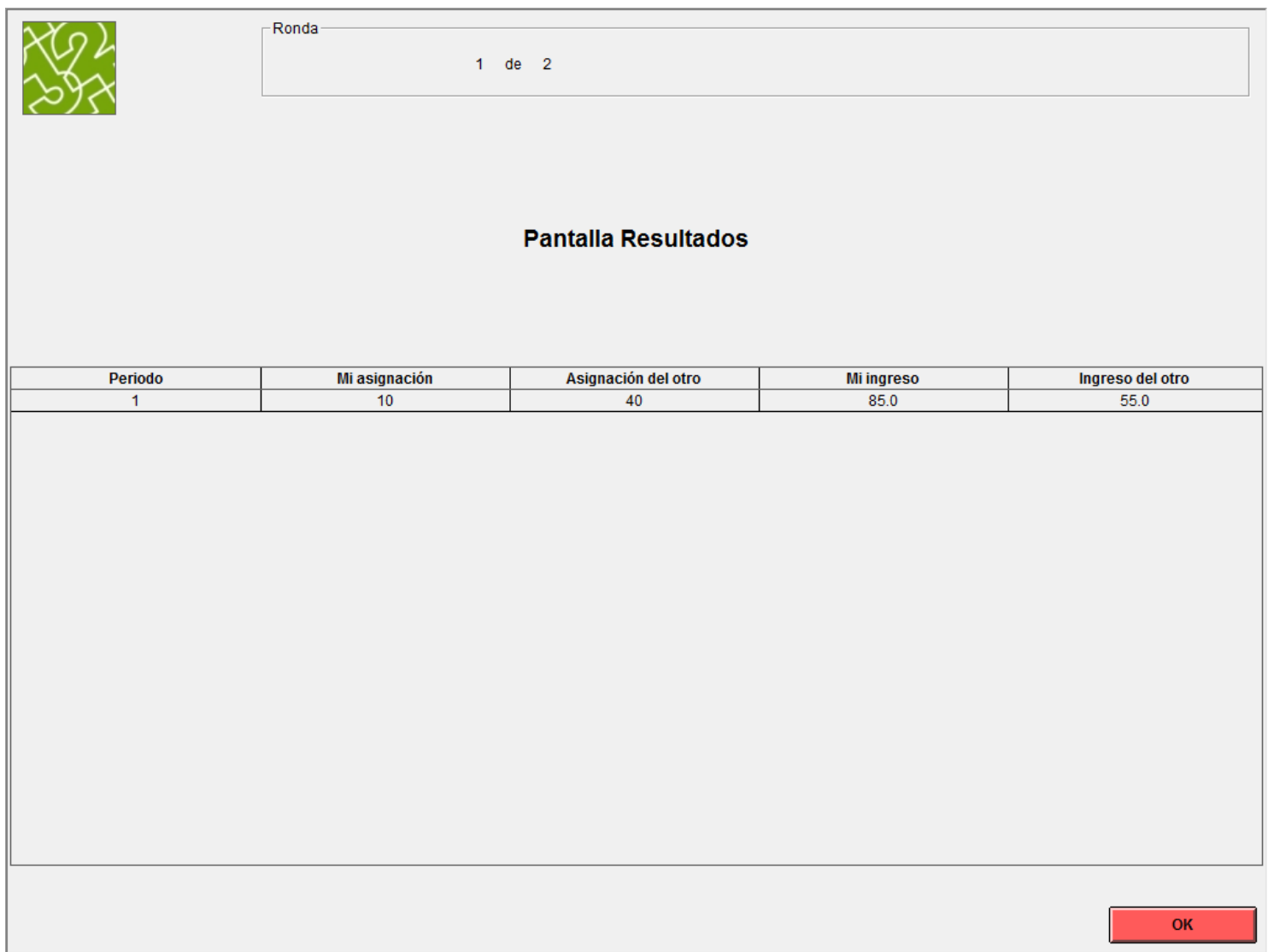

Results screen

Round My allocation Allocation of the other My earnings Earnings of the other $\begin{array}{rrrrr}1 & 10 & 40 & 85.0 & 55.0\end{array}$ 
Screen 39

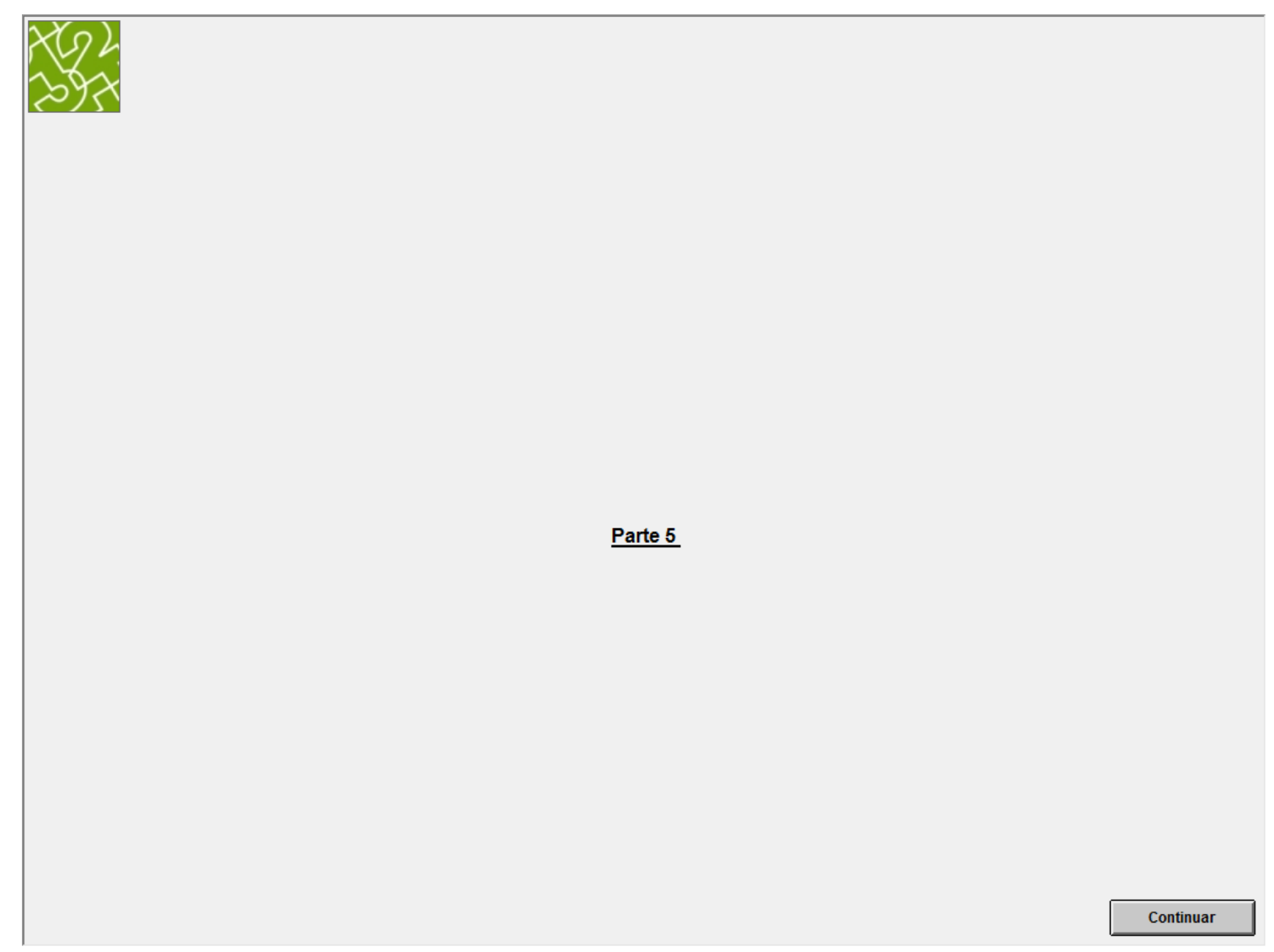

$\underline{\text { Part } 5}$ 
Screen 40

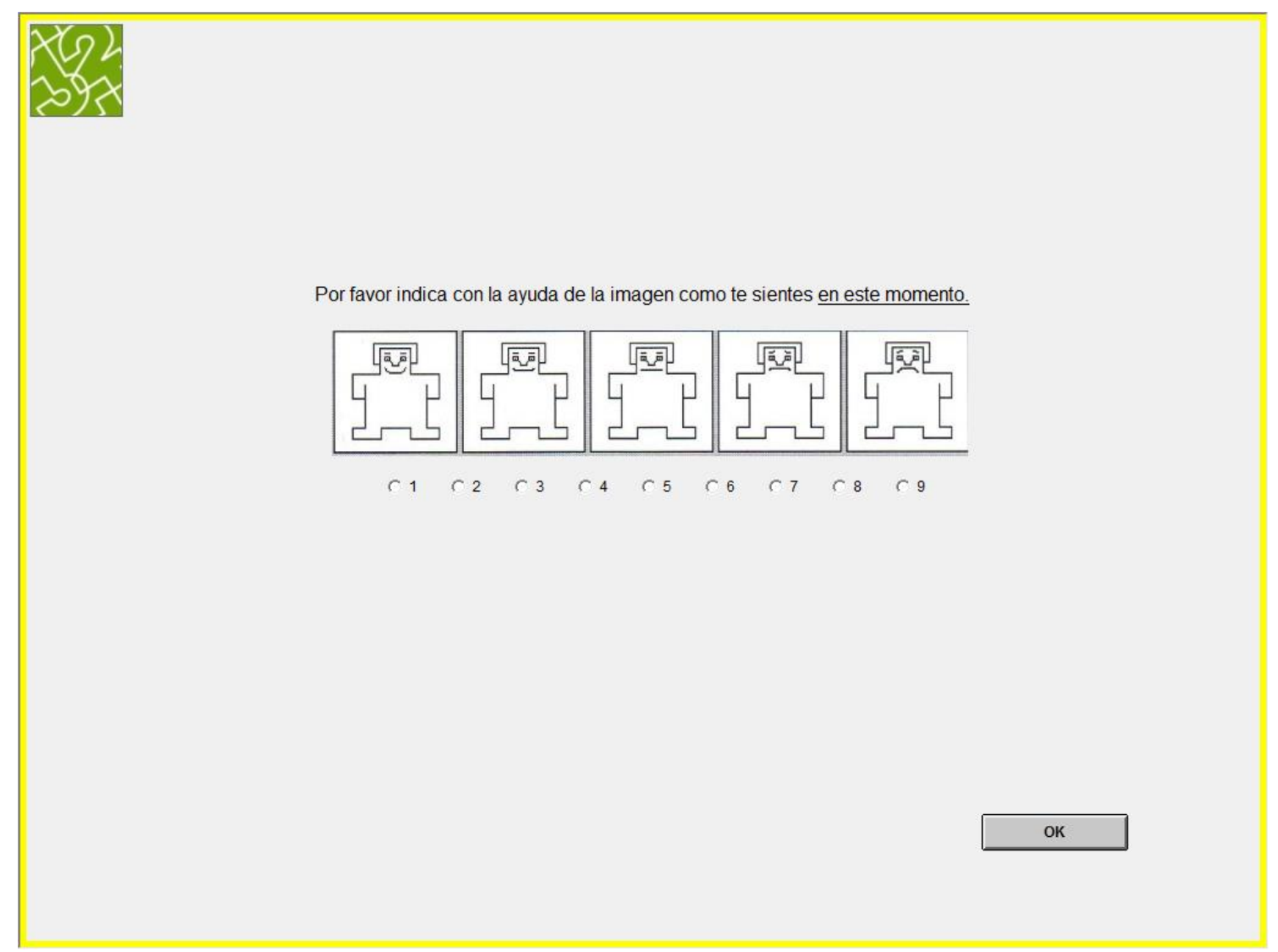

Please indicate with the help of the image how you feel at this moment. 
Screen 41

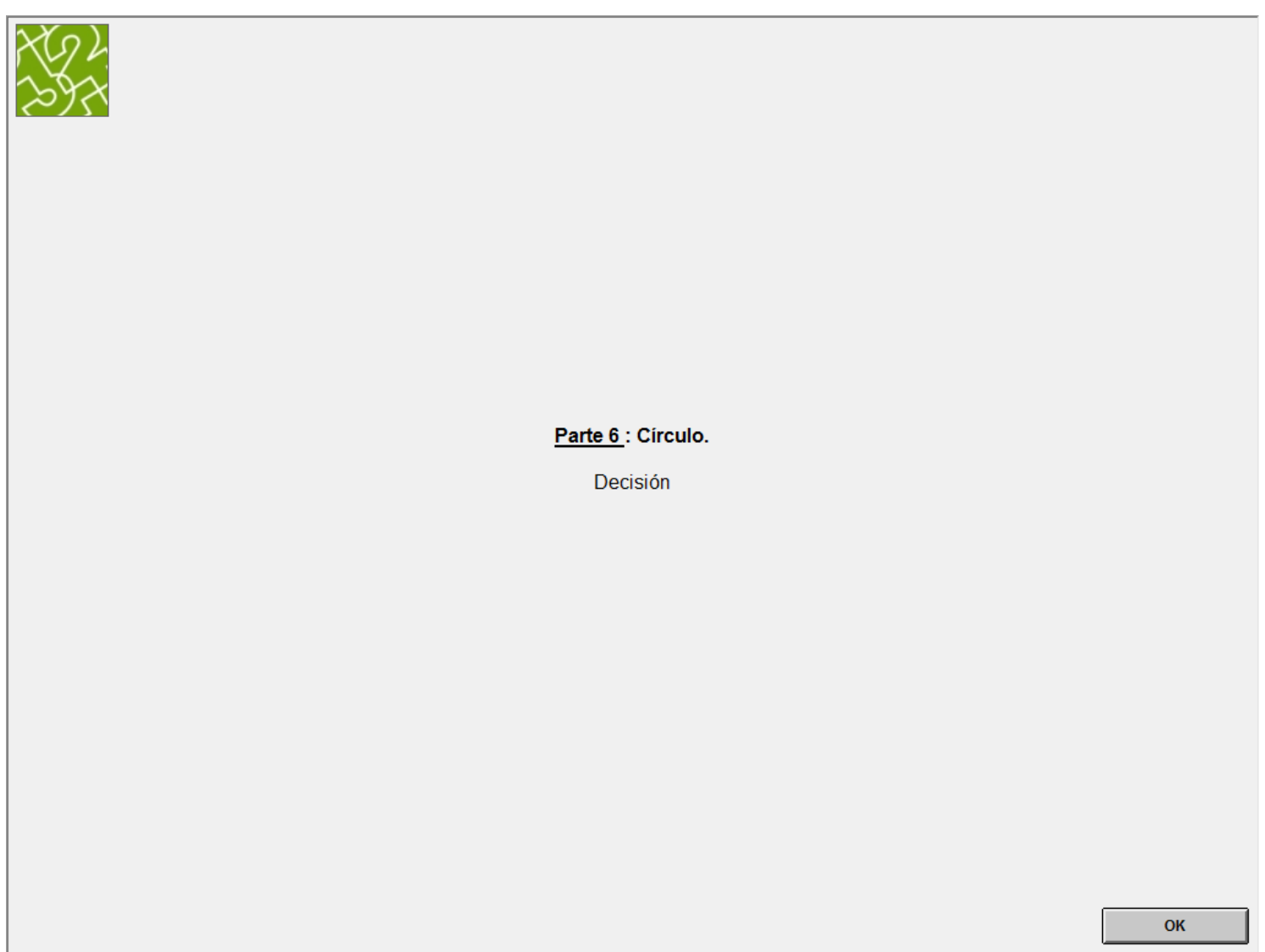

Part 6: Circle

Decision 


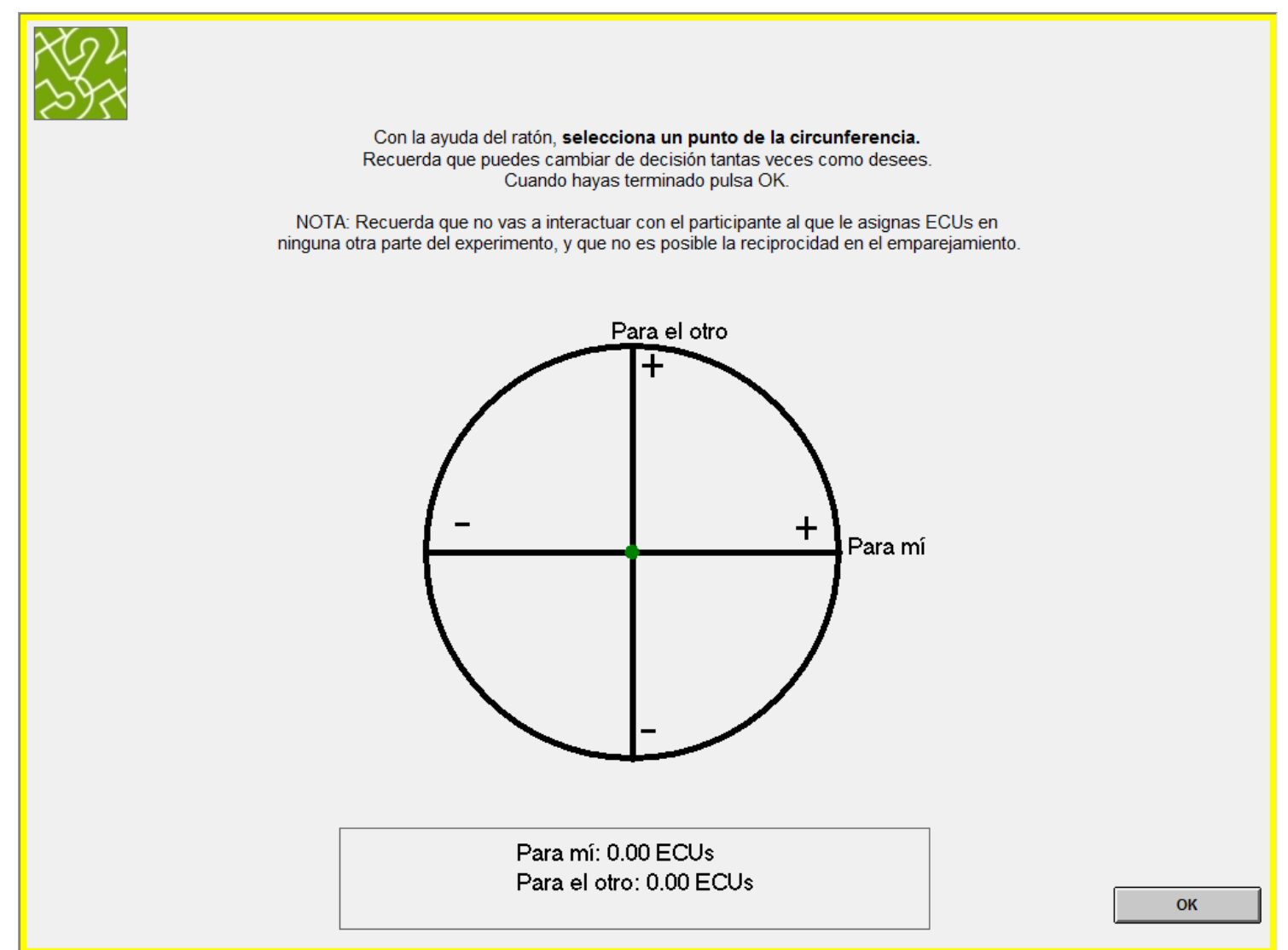

With the help of the mouse select a point on the circle. Remember that you can change your decision as many times as you wish.

When you are finished press OK.

NOTE: Remember that you will not interact with the participant to whom you assign ECUs in no other part of the experiment and that reciprocity in the matching. 
Screen 43

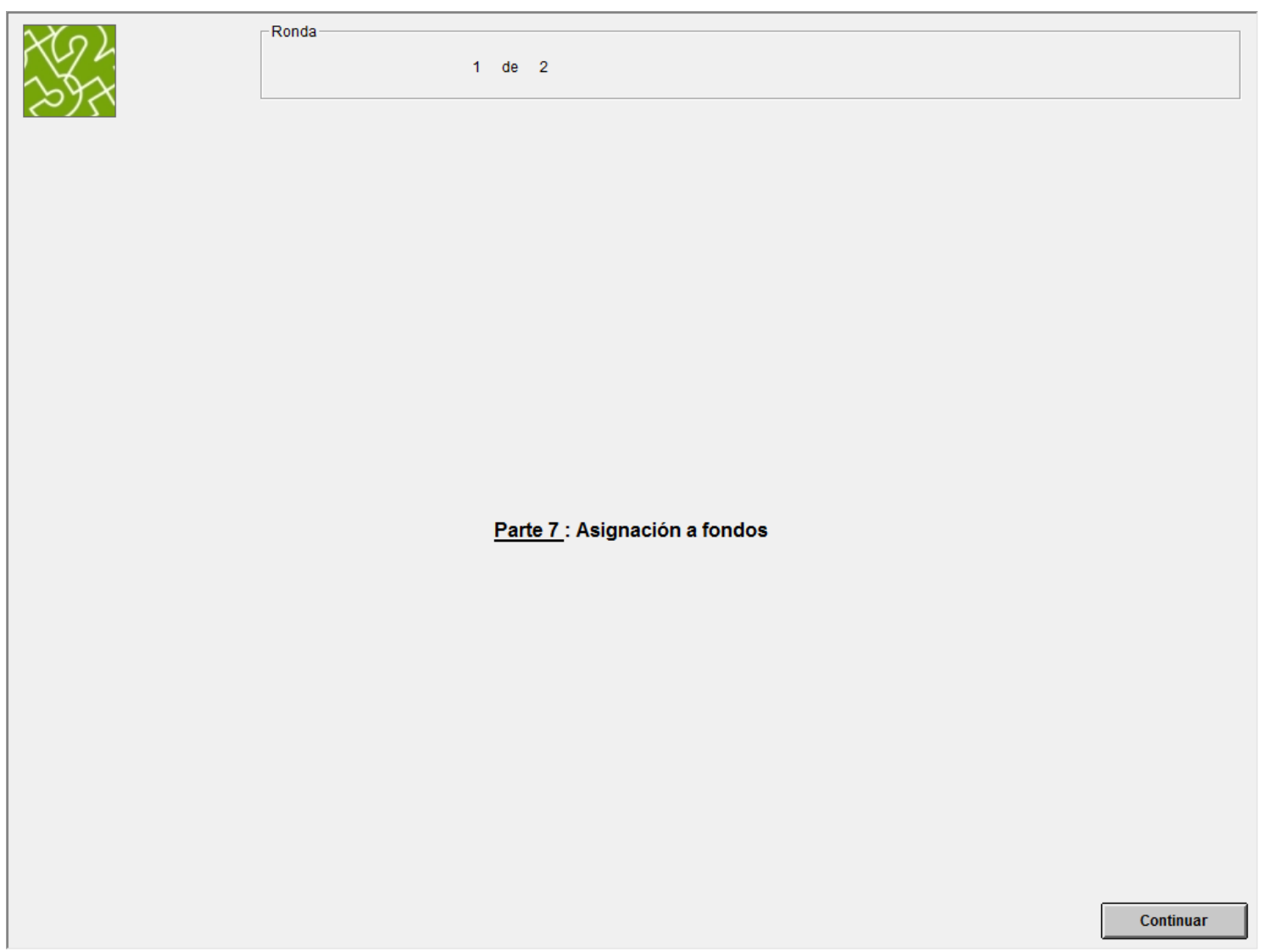

Part 7: Allocation to funds 
Screen 44

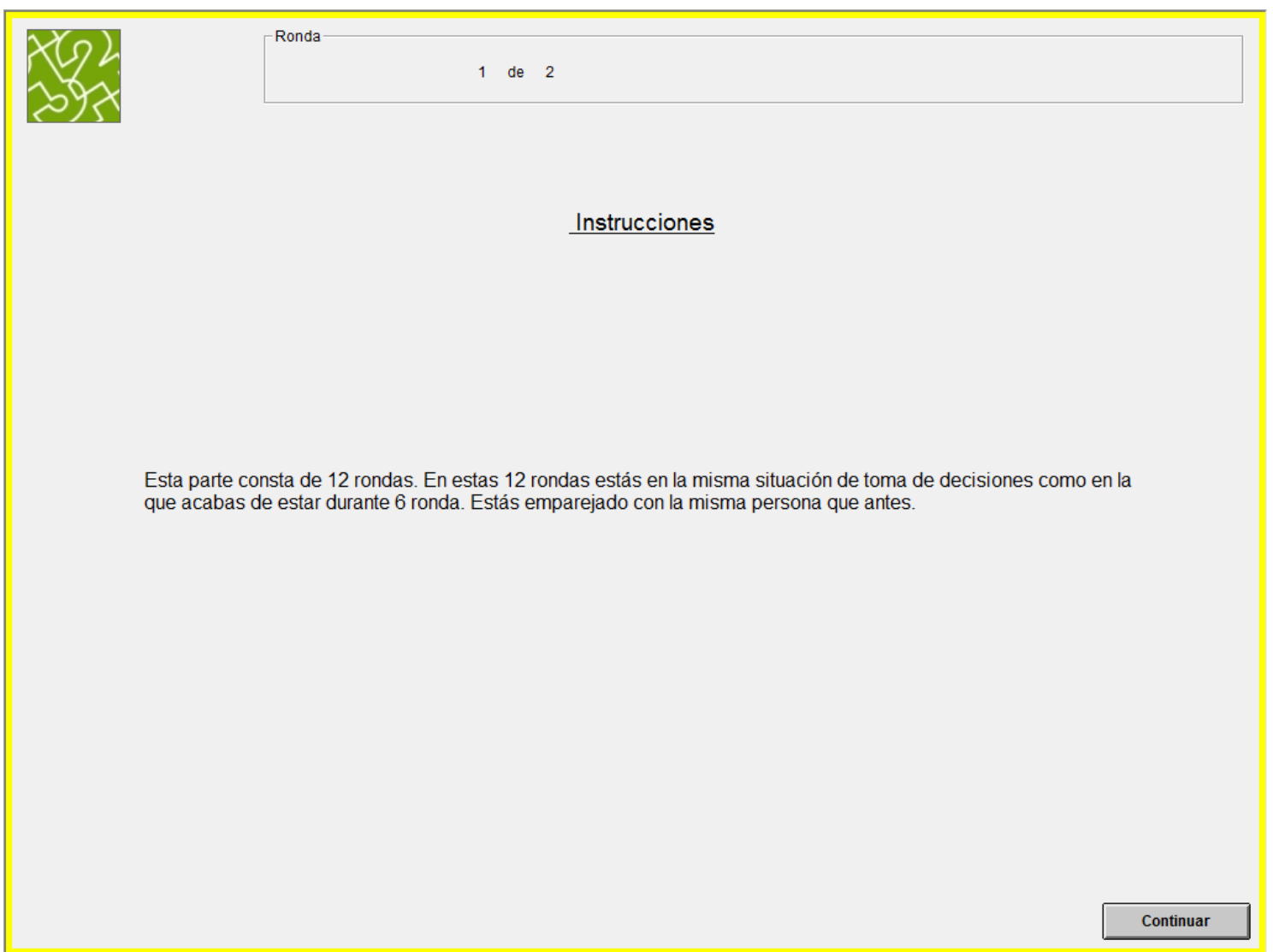

$\underline{\text { Instructions }}$

This part consists of 12 rounds. In these 12 rounds you are in the same decision making situation as in the one that you have just been during 6 rounds. You are paired with the same person as before. 
Screen 45

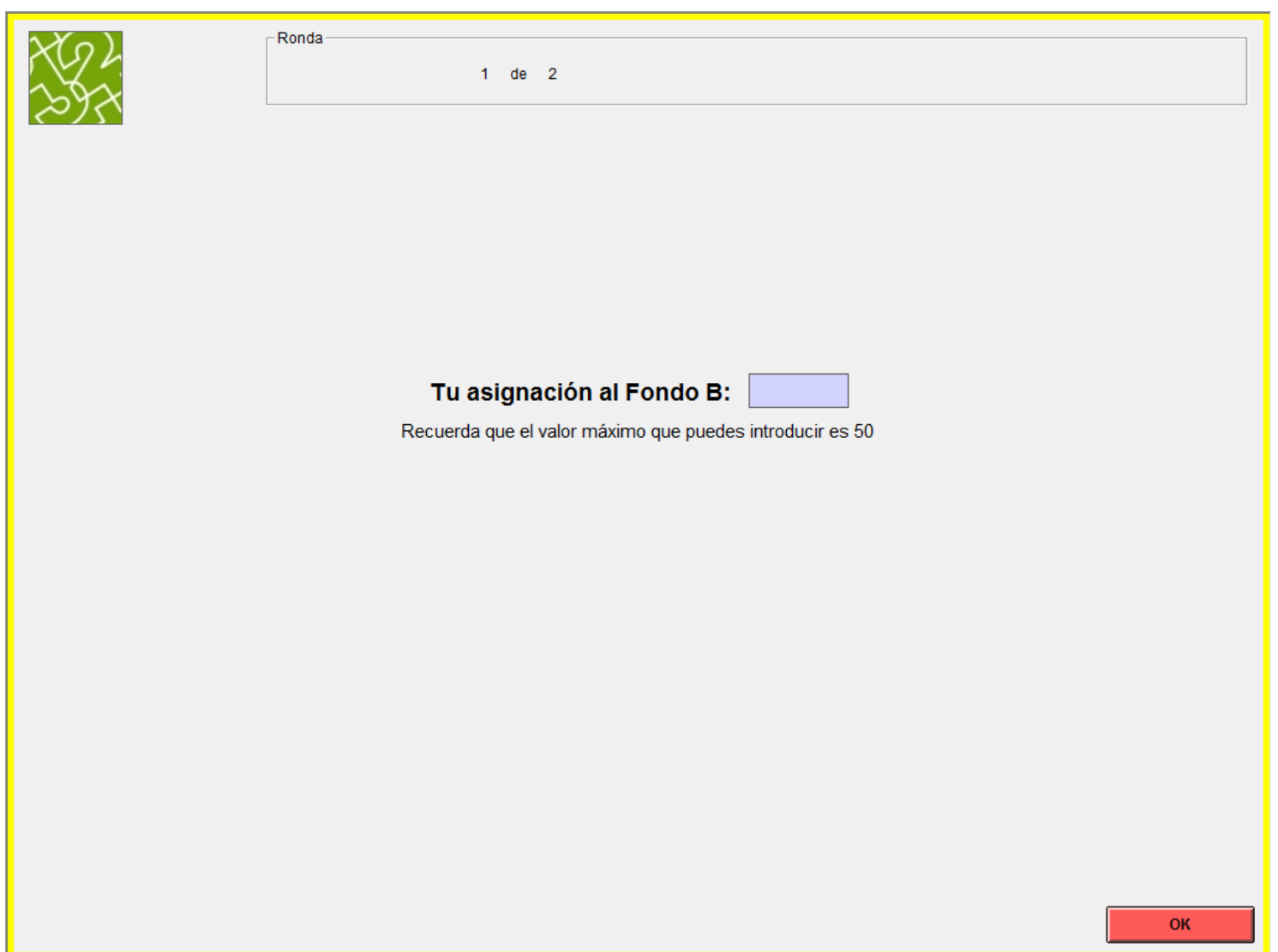

Your assignment to Fund B:

Remember that the maximum value that you can introduce is 50 . 
Screen 46

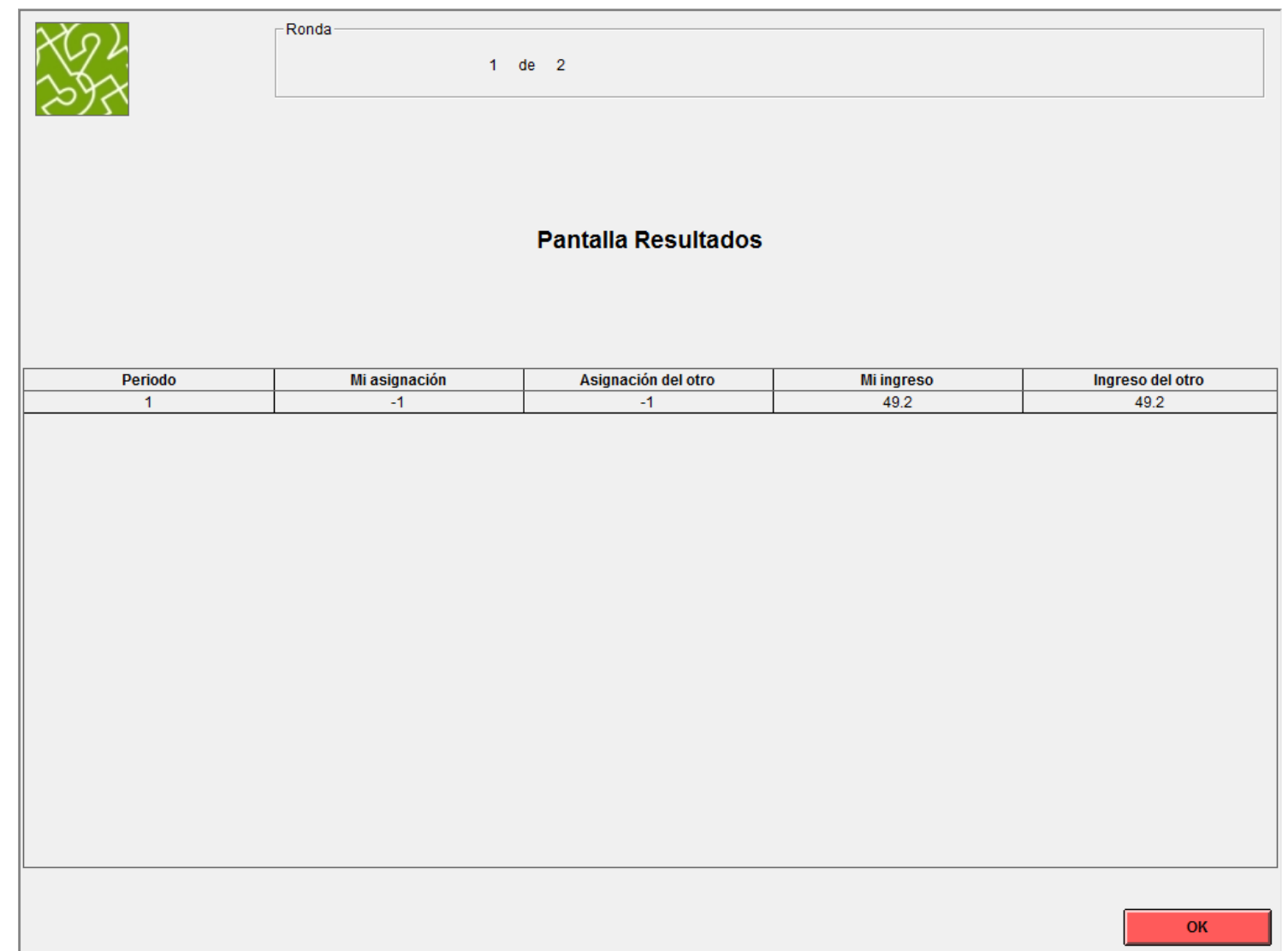

Round My allocation Allocation of the other My earnings Earnings of the other $\begin{array}{lllll}1 & 0 & 0 & 50.0 & 50.0\end{array}$ 


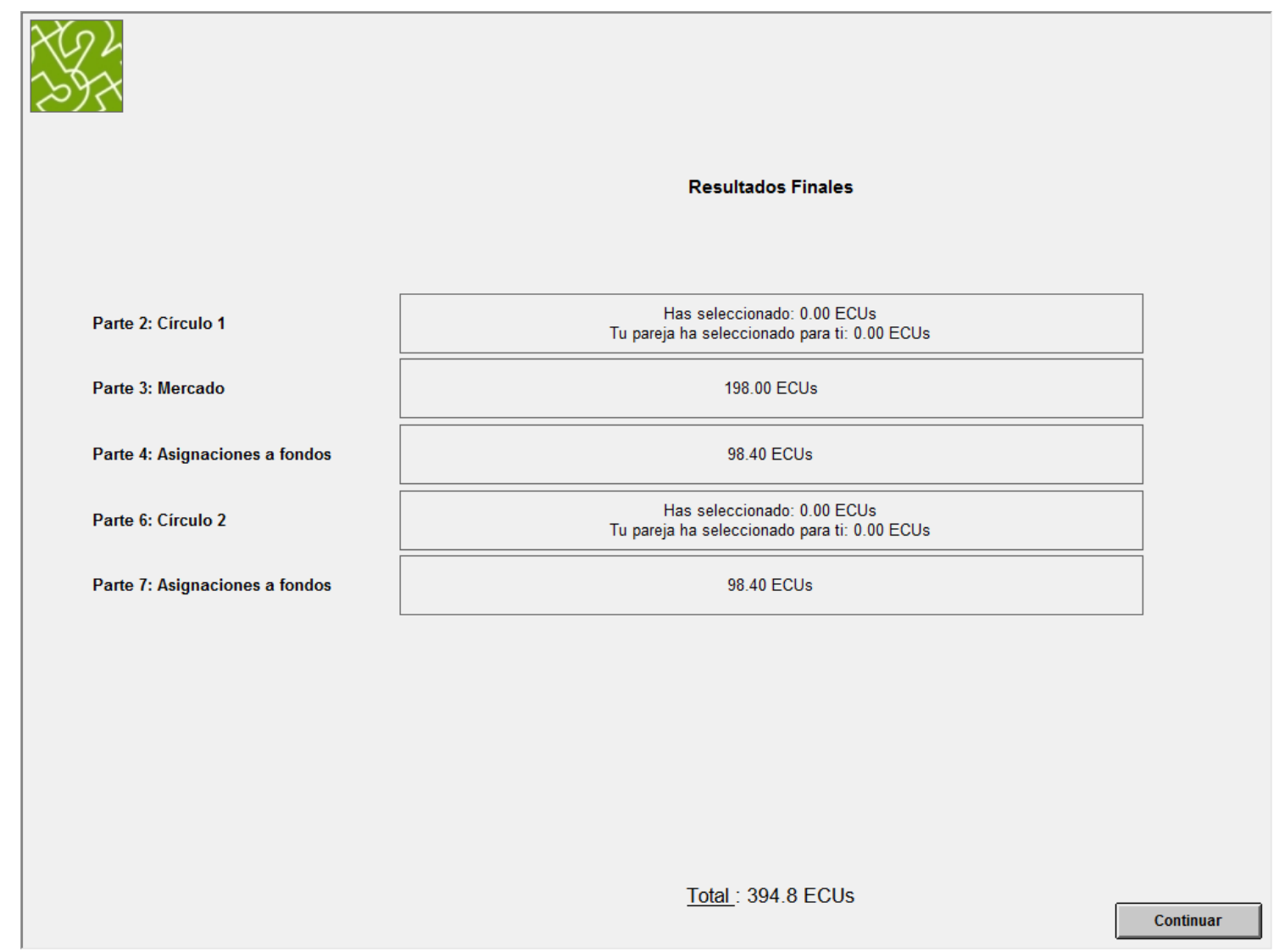

Final Results

Part 2: Circle 1 You have selected 0.00 ECUS. Your partner has selected for you: 0.00 ECUs

Part 3: Market 198.00 ECUs

Part 4: Allocation to funds 98.40 ECUs

Part 6: Circle 2 You have selected 0.00 ECUS. Your partner has selected for you: 0.00 ECUs

Part 7: Allocation to funds 98.40 ECUs

Total: 394.8 ECUs 
Screen 48

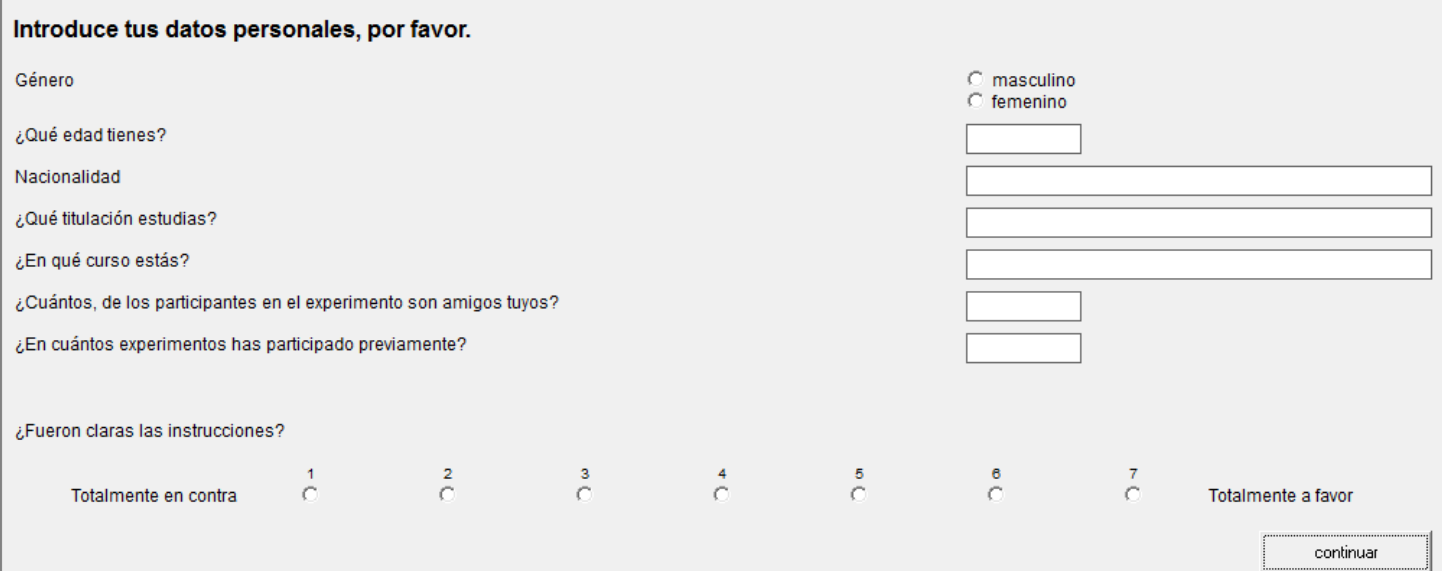

Fill in your personal data, please

Gender: male/female

What is your age?

Nationality

What is your major?

Which year are you in?

How many of the other participants are your friends?

In how many experiments have you already participates

Were the instructions clear on a scale from 1 to 7 ? 